\title{
Solidarity by Association: \\ The Unionization of Faculty, Academic Librarians and Support Staff at Carleton University \\ (1973-1976)
}

by

Martha Attridge Bufton, B.B.A (Hons)

A thesis submitted to the Faculty of Graduate and

Postdoctoral Affairs in partial fulfillment of the requirements for the degree of

Master of Arts

in

History

Carleton University

Ottawa, Ontario

C 2013, Martha Attridge Bufton 


\begin{abstract}
In the mid-1970s, three employee groups at Carleton University changed campus labour relations dramatically: the professors and librarians who belonged to the Carleton University Academic Staff formed the first Ontario faculty union in June 1975; nine months later the Ontario Labour Relations Board certified the Carleton University Support Staff Association as the bargaining agent for the administrative and technical staff. The history of faculty labour action at Carleton has been told but not that of either academic librarians or support staff so this case of unionism provides a unique opportunity to compare their experiences.

Working primarily with oral histories, I argue that status was critical to mobilizing labour action at Carleton. These employees — many of whom were women — wanted a fair workplace but deliberately chose an independent association over a trade union because such "solidarity by association" was compatible with their deeply held beliefs about their work and place on campus.
\end{abstract}




\section{Acknowledgements}

This is first and foremost an oral history project and so the place of honour goes to the women and men who shared their stories-I am most grateful not only for their time but for the legacy they have left to those of us who are working at Carleton University and enjoying the benefits that come from a unionized workplace.

In particular, I want to single out six people whose contributions were particularly generous:

Sylvia Gruda and Pat Finn, leaders of the support staff association during the certification drive, were willing to meet with me more than once, share their personal papers and connect me with other individuals who might have interesting stories to tell.

Likewise, librarians Susan Jackson and Frances Montgomery did not object to being part of a "captive audience" in the library when I needed to check out a fact or share a brilliant insight. I was especially blessed when, upon her retirement, Susan cleaned out her office and found six inches of files devoted to the Association of Professional Librarians of Carleton University, which she did not shred but gave to me. Frances, perhaps inspired by this treasure trove, promptly went to her basement and found her own files — some of which overlapped but many of which did not. Frances, who is a true mentor, is also responsible for my having the opportunities to turn the research on librarians into a book chapter and to learn how to cite provincial legislation. 
Finally, Don and Margaret McEown welcomed me into their home at a time that was challenging for them. Don was dying of cancer and could very easily have passed on the tiring task of answering the questions of someone he did not really know. But he did not and, more than that, he recognized an opportunity for Margaret to tell her story and for me to find out more about the lives of working women at Carleton during the 1960s and early 1970s. They were a delight to be with, particularly as with each interview (there were three in all for this research) they found more stories to share and laugh over. Don has since died but I am glad that I was able to capture some of their infectious enthusiasm, for the university and each other.

I would also like to thank my supervisor Dr. Dominique Marshall for her interest, support and contributions to this thesis as well as my thesis examiners Dr. Joan Sangster (Trent University) and Dr. John Walsh (Carleton University) for their careful attention to my research and insightful questions. In addition, Dr. Pamela Walker's on-going confidence in my ability to wrestle hundreds of pages of transcribed oral histories into something meaningful was encouraging when my own faith faltered.

As usual at a university, the researcher has been nothing without the assistance of support staff.

Linda White, Carleton's former corporate archivist, made this work possible by not only giving me access to the university's corporate files but also for being so thorough that I had a list of all the fonds, boxes and folders that I had consulted to 
refer to any time I needed it. When she left the university and was not replaced, we lost an invaluable resource. Who will be the next Blair Neatby or Don McEown?

Barbara Steele in the University Secretariat has stepped in since Linda left and provided support while Patti Harper, the library's archivist and her crew of Lloyd Keane and $\mathrm{Al} \mathrm{McClellan,} \mathrm{have} \mathrm{given} \mathrm{me} \mathrm{access} \mathrm{to} \mathrm{the} \mathrm{old} \mathrm{issues} \mathrm{of} \mathrm{The} \mathrm{Carleton,}$ This Week Times Two and advice on citing online archival documentsinformation which it turns out is hard to come by in this digital age.

Joan White, the graduate administrator for Carleton's Department of History, is a saint. No email or extension letter is too much trouble. My only regret is that I didn't interview her for this research too because I know that she loved working with Evelyn Aldridge ("Mrs. A."). Regina Aulinskas and Irene Sanna in the main office are always more than helpful—as students we are very lucky to have staff this devoted to working on our behalf.

My colleagues Susan Tudin and Kristof Avramsson in Reference Services at the Carleton University Library were interested in this work-and would take the time to listen and throw out suggestions. This was especially nice at the times when, as a part-time student, I felt isolated and without a cohort to call my own.

Finally, the staff in the Carleton University Library Access Services group were enormously helpful. Christine Taylor and Patricia Paquette of Interlibrary Loans ensured that I received all the materials I requested while Neil McFayden was 
consistently patient as I renewed the over 100 books that I had signed out at one point.

My friend Christina Turnbull has never stopped being enthusiastic about the writing process and has read numerous pages, most of which were not so coherent at the beginning. I needed her zen-like calm—and the coffee at Geronimo's.

My husband Ian Bufton and our sons Bruce and Sean have been steadfast in their understanding and willingness to listen to bits and pieces and proofread, even when what they'd rather be doing was playing basketball. Especially in the last week of writing when I was freaking at the Mount Everest-like stack of footnotes and bibliographic entries left to do, they continued to be supportive. As Bruce said, "They should give you an A for effort Mom-you sure do have a lot of paper there." Ian is a proofreader extraordinaire — thank goodness! Love you lots.

Finally, this thesis is dedicated to my parents, Harriet and Bruce Attridge and my aunt Elaine Empey. Over time, their family stories and loving constancy have kept me connected with my past. I just wish my parents were alive to read this work-I'd like to think they would have enjoyed it. 


\section{Table of Contents}

Abstract................................................................................................................................................

Acknowledgements .......................................................................................................................................iii

Table of Contents..............................................................................

List of Tables, Illustrations and Graphs ..............................................................................................ix

List of Appendices..........................................................................................................................................

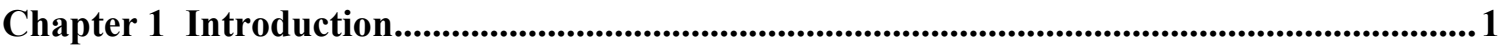

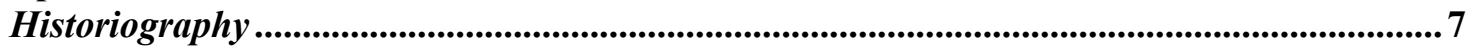

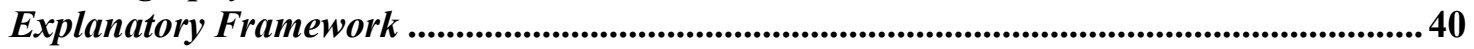

Research Method: Oral History ................................................................................................ 49

Sources and Outline ............................................................................................................................59

Chapter 2

"Taking the plunge": Professors Certify the Carleton University $\ldots . . . \ldots \ldots \ldots \ldots \ldots \ldots \ldots \ldots . . . .63$ Academic Staff Association

Introduction ..........................................................................63

"They Were the University": Creating a Community of Scholars (1942-1973)...............65

The Seeds of Discontent: From Collaboration to Negotiation...............................92

Going from Association to Union: “Michael Made Some Mistakes”.......................102

Conclusion and Epilogue.............................................................. 152

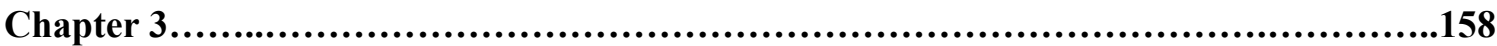

A "Honey" of a Union Deal: The Labour Action of Carleton University Librarians

Introduction .........................................................................158

Hilda Gifford and Early Recognition for Librarianship at Carleton (1948-1968)...........161

Conversations About the Status of Librarianship.........................................182

The Association of Professional Librarians of Carleton University joins CUASA ...........189

Overcoming the Resistance of Professors..............................................202

Conclusion and Epilogue..............................................................

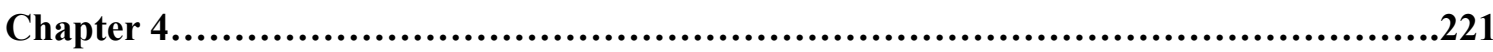

Not to be "Squeezed Out": The Carleton University Support Staff Union

Certifies

Introduction ...........................................................................221

Creating An Identity: “Our Work is Necessary and Requires Skill”........................223

Organizing Support Staff at Carleton....................................................265

Part A. Mobilizing Library Workers: “We Saw a Situation that was Unfair”............265

Part B. Organizing Support Staff: "You Gotta Have a Union" .............................281

Overcoming Resistance: From “Workers' Plight” to "More Clout”..........................306

Part A. Pros and Cons of Collective Action ............................................306

Part B. Framing the Issues and Securing Support.....................................322

Conclusion and Epilogue: "Equal Pay for Work of Equal Value"......................................336

Chapter 5 ............................................................................................................................................................. 340

Conclusion: Noisy, Uppity and Organized

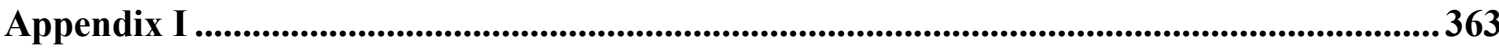




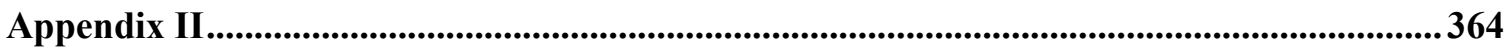

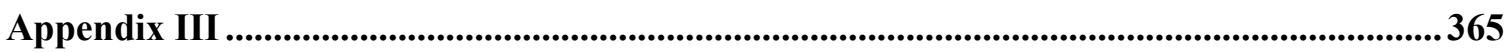

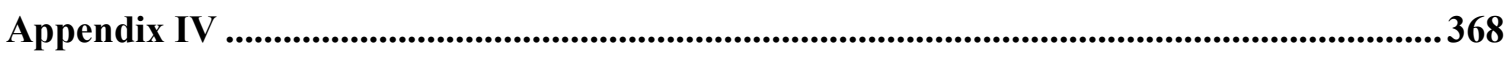

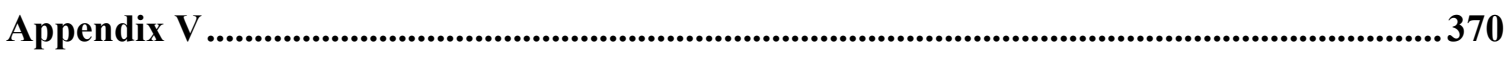

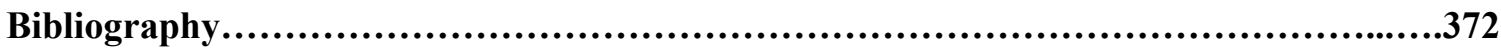


List of Tables, Illustrations and Graphs

Table 2.1 Median Salaries of Academic Staff (1931-1971)...................96

Table 3.1 Salary Scales for Ontario University Librarians.....................178

Table 4.1 Administrative and Technical Support Staff Classes...............334

Illustration $2.1 \quad$ "Shabby Suit" .....................................................147

Illustration 2.2 "Chronicles of Old Carleton": Veni, Vidi, Vici .....................148

Illustration 4.1 "Has Everybody Got Enough of This Stuff" ......................... 325

Illustration 4.2 "What's Going on Here"

Graph 4.1 Carleton University Board of Governors

New Hires of Academic Staff.....................................240

Graph 4.2 Carleton University Board of Governors

New Hires of Library Staff.....................................241

Graph 4.3 Carleton University Board of Governors

New Hires of Administrative and Clerical Staff..................241

Graph 4.4 Carleton University Board of Governors

New Hires of Technical Staff.....................................242 
List of Appendices

Appendix I $\quad$ List of Interviewees..............................................363

Appendix II List of Questions for interviewees .................................. 364

Appendix III Letter of Information ............................................365

Appendix IV Informed Consent Form..........................................368

Appendix V Ethics Clearance Form...............................................................370 


\section{Chapter 1 Introduction}

Over an eight-month period in the mid-1970s, three occupational groups at

Carleton University changed campus labour relations significantly: the professors and

librarians who belonged to the Carleton University Academic Staff (CUASA)

successfully applied to the Ontario Labour Relations Board (OLRB) for certification

which was granted in July 1975; likewise, in March 1976 the OLRB certified the

"Carleton University Support Staff Association (CUSSA) as the bargaining agent of all

employees engaged by Carleton University ... in clerical, technical, administrative and

service duties." CUASA was the first academic staff union in the province while the

CUSSA members participated in the initial wave of university support staff

unionization; ${ }^{2}$ together they represented $80 \%$ of the employees at Carleton. ${ }^{3}$ Academic

\footnotetext{
${ }^{1}$ Certificate 1455-R Carleton University Support Staff Association (March 4, 1976), Carleton University Support Staff Association (Applicant) v Carleton University (Respondent) v Group of Employees (Objectors), 1. This certification excluded a number of Carleton employees including those already covered by existing collective agreements: members of the Graphic Arts International Union, the Canadian Union of Public Employees (CUPE) Local 910, the International Union of Operating Engineers (IUOE) and the Canadian Guard Association. There is reference to a contract between the university and the IUOE in the official Board minutes of March 28, 1962 and a schedule of salaries for CUPE 910 members in the Board minutes of November 10, 1966. Carleton University (hereafter CU), Minutes of the $139^{\text {th }}$ Meeting of the Board of Governors, (hereafter BOG) March 28, 1962), 4; CU, Minutes of the $192^{\text {nd }}$ Meeting of the BOG, November 10, 1966, 6-7, Board of Governors fonds, Carleton University Corporate Archives, Ottawa, Ontario, http://www6.carleton.ca/records/historic-minutes-of-the-board-ofgovernors, accessed November 25, 2013.

Note: All subsequent Board of Governors minutes are found in the same fonds in the Carleton University Corporate Archives and were accessed via the same URL (for final confirmation) on November 30, 2013. As such, this information will only be cited once, in this footnote. Subsequent footnotes will be referenced back to FN 1, Chapter 1. In addition, the Ottawa Association for the Advancement of Learning (the organization originally responsible for Carleton College) are found in the same fonds in the Carleton University Corporate archives and the citations will also be abbreviated as follows: OAAL, Minutes of the 26th Meeting of the BOG, October 17, 1946.

According to Tony Cristiano (the current national representative for both CUPE 2424 and CUPE 910) members of the IUOE certified as CUPE 910 in 1966. Tony Cristiano, e-mail to the author, November 25, 2013.

${ }^{2}$ Charlotte R. Mudge, "Bargaining Unit Composition and Negotiation Outcomes: A Study of Academic and Public Library Personnel in Ontario" (doctoral thesis, University of Toronto, 1984), 2. http://search.proquest.com/docview/303377903? accountid=9894.

${ }^{3}$ According to the Carleton University Data Book 1974-75, 1,681.5 employees worked at the university and 1,330.5 held faculty, librarian, administrative and technical positions. Carleton University, Carleton University Data Book, 1974-75, (Ottawa: Carleton University, 1975), 48. Note: These data books
} 
and university support staff can be broadly defined as "white-collar" workers who, unlike their "blue-collar" counterparts, traditionally have not joined trade unions. ${ }^{4}$ Based on ideas about the nature and value of their work, many have long believed that this form of workplace collective action is, for them, inappropriate, unnecessary or both.

As such, the events at Carleton reflect a process that historians generally consider to be a significant transformation in white-collar workers' practices. Indeed, during the 1960s and 1970s these workers began to unionize in greater numbers across the country and, while the rise of white-collar unionization has been studied in other institutional contexts, our understanding of the experiences of university workers in English Canada is incomplete. The historical literature on Anglophone Canadian university-based unions focuses overwhelmingly on the activities of professors and there is virtually no discussion of those of other employees such as librarians, clerical staff or technicians. As a result, it is unclear if the unionization of faculty members is representative of that of other whitecollar university employees. During this period, each of these employee groups had distinct occupational identities and it cannot be assumed that they chose to unionize for

are available from the Office of Institutional Research and Planning at Carleton University. As such, this information will only be cited once, in this footnote. Subsequent footnotes will be referenced back to FN 3, Chapter 1.

${ }^{4}$ White-collar and blue-collar are contested terms to describe different forms of work. For the purpose of this thesis, I will define these terms as per Sylvia Ostry's 1967 labour force study entitled The Occupational Composition of the Canadian Labour Force. She defines blue-collar work broadly as manual (e.g., farmers and farm workers) and white-collar work as non-manual (e.g., those working in clerical, professional, managerial jobs). Sylvia Ostry, The Occupational Composition of the Canadian Labour Force. One in a Series of Labour Force Studies in the 1961 Census Monograph Programme (Ottawa: Dominion Bureau of Statistics, 1967), 3-6. For a case study of white-collar public sector unionization, see Anthony Thompson, "The Nova Scotia Civil Service Association, 1956-1967," in Canadian Working Class History, $2^{\text {nd }}$ ed., eds. Laurel Sefton MacDowell and Ian Radforth (Toronto: Canadian Scholar's Press Inc., 2000), 641-61. Thompson suggests that members of the Nova Scotia Civil Service unionized in part due to financial constraints that affected wage increases but that unionization may not have signalled a fundamental change in the traditional service ethic and approach to employee-employer relations that characterized these employees. 
the same reasons. In addition, while the majority of Canadian professors were men, a significant proportion of employees in the other two occupations were women. ${ }^{5}$

The certification of the academic and support staff associations at Carleton University provides a unique opportunity to do a comparative study of the union formation of three occupational groups. Using an analytic framework based on the concepts of status and gender, the experiences of professors, librarians and support staff during their respective certification drives will be studied. Attention will be paid to the motives of group members including their reasons for supporting or opposing unionization, the events that triggered collective action and the ideas that leaders used to encourage mobilization. Personal narratives and original documentary evidence will be used to argue that status played a significant role in the unionization of each group in two significant ways: first, by shaping the overarching identities of each group and thus creating a gendered occupational hierarchy within the university; and second, by informing the moral expectations of both men and women as to their roles within the institution and the appropriate forms of recognition they should receive. A majority of members in each group voted to unionize not just because they believed that their jobs were threatened, but also because they thought their contributions to the university were

\footnotetext{
${ }^{5}$ In their official report, the commissioners of the Royal Commission on the Status of Women in Canada indicated that in $1969,46.2 \%$ of all women worked in the "community, business and service" sectors of the Canadian economy and that $69.2 \%$ of all clerical workers were female while only $43.6 \%$ of all technical workers were women. The commissioners also reported that only $8 \%$ of students in doctoral programs were women. Royal Commission on the Status of Women in Canada. Report of the Royal Commission on the Status of Women in Canada, (Ottawa: The Commission, 1970), 57, 59 and 169. The Canadian Association of University Teachers (CAUT) made a submission to the commission on the status of women in academia and reported that 1,385 of its 11,156 members (or 12.4\%) were women. Canadian Association of University Teachers, Submission to the Royal Commission on the Status of Women (1967), 3. In addition, Carleton University did not start publishing official statistics that included the breakdown of employee groups by sex until the latter half of the 1970s. However, statistics contained in the Carleton $1977-78$ data book indicate that $90 \%$ of the professors were men and $84 \%$ of the administrative and technical support employees were women. Carleton University, Carleton University Data Book 1977-78, (Ottawa: Carleton University, 1978) 61-2, FN 3, Chapter 1.
} 
not properly recognized or rewarded by senior university administrators. Moreover, gendered social roles intrinsically shape occupational status and, in particular, women in all three groups at Carleton were mobilized to unionize in protest against workplace practices they considered unjust. Consequently, although these occupational groups are typically perceived and studied as if they are inherently dissimilar, this case of certification reveals that at this historical moment at Carleton University, professors, librarians and support staff shared very similar experiences and concerns.

Professors, librarians and support staff had had the legal right to apply to form a trade union since 1944 under the Ontario Labour Relations Act. However, each group had chosen to either belong to a voluntary staff association or remain unaffiliated with an occupationally related organization. ${ }^{6}$ Beginning in the early 1950 s professors at Carleton University had the option to join CUASA, the faculty voluntary association. Over time CUASA representatives began to make regular salary and benefits requests to the president but they did not formally negotiate terms and conditions of work. ${ }^{7}$ In the 1960 s, administrative and clerical staff could belong to a social club called the Carleton Staff Association. Members met for dinner at the local Hunt Club Golf Course, produced Christmas cookbooks, and generally had "a lot of fun" according to Margaret McEown who worked as an administrator in the university's personnel department from 1965 to 1974. ${ }^{8}$ In contrast, librarians were a tightly knit group that took coffee together every day

\footnotetext{
${ }^{6}$ For an overview of historical changes to Canadian labour legislation, see Judy Fudge and Erick Tucker "Pluralism or Fragmentation?: The Twentieth-Century Employment Law Regime in Canada," Labour / Le Travail 46, Special Millennium Issue (Fall 2000): 251-306.

${ }^{7}$ H. Blair Neatby and Don McEown, Creating Carleton: The Shaping of a University (Montreal, Kingston: McGill-Queen's University Press, 2001), 163.

${ }^{8}$ Margaret McEown, retired personnel officer, Carleton University, in oral history interview with the author, April 21, 2011. McEown was hired at Carleton University effective July 1, 1965 as the science faculty secretary at a monthly salary of $\$ 300$. CU, Minutes of the $167^{\text {th }}$ Meeting of the BOG, June 24, 1965), 5, FN 1, Chapter 1.
} 
but remained formally unorganized until they founded a professional association in 1973, just prior to being eligible to join CUASA in 1974. If none of these employees were unionized in the period prior to the 1970 s, it is largely because many thought trade unions were not for them. Engineering professor David Coll shared the view of a number of his colleagues that professors were not employees: "we were the university;" and McEown remembers thinking that a union was not appropriate for her because "unions were for the lower classes ... for people who needed the protection more" rather than administrators like herself. ${ }^{10}$

By the mid-1970s, however, faculty and support staff, including those who belonged to the voluntary associations CUASA and CUSSA, were beginning to actively discuss the possibility of forming trade unions while the librarians formed the Association of Professional Librarians at Carleton University (APLCU) in $1974 .{ }^{11}$ Then, according to Professor Andy Brook, almost overnight, they all "had a union." ${ }^{12}$ By late 1974, CUASA leaders had formed a collective bargaining committee and were planning information sessions for faculty in early 1975 . CUSSA members proceeded more cautiously and in early 1975 attempted to gain voluntary recognition from the Carleton governing board as the sole bargaining agent for their members. However, when this request was denied, the executive council decided to launch a certification campaign in

\footnotetext{
${ }^{9}$ David Coll, retired professor, Carleton University, in oral history interview with Margaret Coll and the author, May 18, 2011.

${ }^{10} \mathrm{M}$. McEown, oral history. (I have used this abbreviation for subsequent citations of Margaret McEown's interview to distinguish it from that of her husband Don McEown. For consistency, I will do this with the subsequent citations of all the oral histories).

${ }^{11}$ Susan Jackson, retired librarian, Carleton University, in oral history interview with the author, April 8, 2011.

${ }^{12}$ Andrew Brook, professor, Carleton University, in oral history interview with the author, April 17, 2011.
} 
June of that year. ${ }^{13}$ When leaders believed that unionization had become viable option, both CUASA and CUSSA members changed their constitutions, recruited more participants, applied to the OLRB for union status and were each certified within three months of submitting their application to the labour board. What changed? If unionization had been "unimaginable" in an earlier period, how did this form of collective action seemingly become legitimate so quickly for a majority of the members in all three occupational groups? ${ }^{14}$

Historian H. Blair Neatby and co-author Secretary Emeritus to the Carleton Board of Governors Don McEown discuss briefly the unionization of professors in their institutional history of Carleton University Creating Carleton. The Shaping of a University, published 12 years ago. ${ }^{15}$ They suggest several possible explanations for faculty collective action but do not address that of librarians or support staff-an omission that would not surprise Susan Jackson, the long-time head of the Carleton library's Maps, Data and Government Information Centre (MADGIC). As she points out wryly, "I think a great deal of my time with CUASA has been [spent] correcting people who say 'Faculty Association' to say 'Academic Staff Association'." ${ }^{16}$ In addition to other histories of Canadian higher education, three areas of historical research provide a

13 "Critical Juncture," the What? 2, no. 3 (July/August 1975): 10, Carleton University Support Staff Association Fonds, CUSSA-001-4, "The What? 1974-1977, Carleton University Corporate Archives, Ottawa, Ontario. Note: All subsequent issues of the What? are found in the same fonds in the Carleton University Corporate Archives. As such, this information will only be cited once, in this footnote. Subsequent footnotes will be referenced back to FN 13, Chapter 1. In the title of the fonds, the What? is capitalized: "The What?."

${ }^{14}$ Neatby and McEown, Creating Carleton, 195.

${ }^{15}$ As Neatby explains in his acknowledgements, as he began to write this history he found himself "turning regularly to Don McEown for information and advice" and eventually asked McEown to be his co-author. Neatby and McEown, Creating Carleton, 233.

${ }^{16} \mathrm{~S}$. Jackson, oral history. 
context within which to begin to do this comparative research to help fill the gap: labour, libraries and women.

\section{Historiography}

Often university histories are written to celebrate the "birth and growth to maturity" ${ }^{\prime 17}$ of a particular institution during an anniversary year but this was not Neatby's intention when he co-wrote a history of Carleton University with McEown. Neatby was interested in the development of higher education in Ontario, including the "unique concerns of individual universities." ${ }^{18}$ He chose Carleton as a case study and, rather than writing a commemorative chronology, explored the university's evolution within the broader social, political and economic contexts in which it operated to determine "how did this institution become the way it was?"19 Creating Carleton covers the first three decades in the development of the university, from 1941 to the end of 1969. Neatby and McEown base their research on archival materials such as minutes from the meetings of the Board of Governors and Senate but Neatby believes that "these are often dull documents, with the clashes and confrontations carefully excised" so their evidence also includes back issues of the university and CUASA newsletters in addition to issues of the student newspaper and "memories" of colleagues including administrative staff who had been on campus for specific events. ${ }^{20}$

\footnotetext{
${ }^{17}$ Walter H. Johns, A History of the University of Alberta, 1908-1969 (Edmonton: University of Alberta Press, 1981), ix.

${ }_{18}^{18}$ Neatby and McEown, Creating Carleton, 233.

${ }^{19}$ Ibid; H. Blair Neatby, retired professor, Carleton University, in oral history interview with the author, April 20, 2011. Neatby does not appear to have been asked to write an official history of the university. Instead, he seems to have been motivated by a particular interest in the history of higher education in Ontario. In his published works, Neatby uses "H. Blair Neatby," which I have used in this first reference. In subsequent references in the text I will refer to him as "Blair Neatby" or "Neatby" where appropriate.

${ }^{20}$ Neatby and McEown, Creating Carleton, 234.
} 
Although the book excludes the years in which both faculty and support staff unionized, the authors discuss the certification of CUASA briefly in the epilogue. Neatby and McEown argue that unionization represented a significant change in labour relations on campus, one that professors would have considered "unthinkable" in the past. ${ }^{21}$ Although they stop short of offering a definitive explanation for this change, the authors suggest that three factors could should be considered when examining the process of unionization at Carleton: key environmental factors; the lack of a class-based certification campaign; and occupational status.

According to Neatby and McEown, unionization was the product of "shifting circumstances" in Ontario and more generally in Canada that led to disappointed expectations. The 1960s had been a period of unprecedented growth in Canadian higher education, facilitated by increased financial support from both the federal and provincial governments. Faculty from coast to coast were "optimistic" because they had more job opportunities, salary increases, the chance to develop new programs and curricula as well as access to higher levels of research funding from the federal government. Neatby and McEown argue that in this period of prosperity, academics had developed "unrealistic expectations based on an inflated view of the prestige of academics in a post-industrial society." 22 They believe that these hopes went unfulfilled in the 1970 s when, for a number of reasons including decreasing public support for higher education, governments reduced funding for both capital and operating budgets. These cutbacks in financial support left university administrators with potential budget deficits and the possibility of

${ }^{21}$ Ibid., 197. Neatby and McEown only refer briefly to the fact that other Ontario faculty association executives were discussing unionization. They suggest that newer universities were likely to unionize due to a lack of financial stability whereas those at "more established" institutions opted for voluntary recognition. They do not, however, offer a fuller explanation as to why this pattern seemed to emerge.

${ }^{22}$ Ibid., 195. 
having to eliminate faculty jobs in order to minimize financial shortfalls. The authors conclude that, partially in response to these changes, members of faculty associations across the country were either actively considering certification or had already voted to form a union.

At Carleton, McEown and Neatby suggest that this general atmosphere of "gloom" was compounded by two other factors that triggered the decision to apply for certification. Primarily they believe that many CUASA members felt concerned because they thought their jobs could be in jeopardy, given the fact that the university's tenure and dismissal policy did not include rules to govern dismissal at "times of financial stringency." In the 1970s when money was tight, senior and tenured faculty as well as younger and nontenured professors generally felt vulnerable. Neatby and McEown also argue that the other critical factor was mistrust as a significant number of academic staff did not believe that President Michael K. Oliver would advocate effectively for them with the provincial government. While many professors felt suspicious and insecure, not everyone was in favour of certification. Those from specific disciplines, such as engineering and economics, openly opposed unionization on the grounds that it contradicted scholarly values such as academic freedom and the duty to teach. In the tradition of collegiality, association leaders "stressed" the protective potential of collective bargaining in response to this opposition and avoided attacks on the president or "a clarion call to join the class struggle. ${ }^{, 23}$ The two authors rightly observe that, given that $80 \%$ of CUASA members voted in favour of a union, "Whatever the explanation, the professors and librarians at Carleton were now committed to collective bargaining." 24

\footnotetext{
${ }^{23}$ Ibid., 197.

${ }^{24}$ Ibid., 198.
} 
This history of unionization owes much to Neatby's work as a political historian. In the tradition of classic Canadian political history, his earlier scholarship focused on elite decision makers, key events and national politics, conceptualizing power as the ability to make decisions, and studying it on a macro scale. ${ }^{25}$ He has written Creating Carleton on a smaller scale than his former work, using a single university as a case study, but he has continued to explore important events and broad social and political trends by focusing on elites - presidents, senior university administrators and board members - those, he believes, who have had institutional power. This approach could be considered an example of what Peter Burke has characterized as the "old" history, which bases its analysis on documentary evidence and can be described as focused on influential institutions, written as a narrative of events and privileging of the role of decision makers - the view from the "top." ${ }^{26}$ Within this "paradigm" the agents of historical transformation are individuals and groups.

In some respects, however, Creating Carleton is also representative of the "new history." This alternative historiographical approach is more social or cultural than political in nature and explores the experiences of marginalized groups - the view from "below"- as well as the role of social structures in constraining the ability of human agents to effect change; "historians appear to be increasingly open-minded about explanations" and sources include but are not limited to documents. ${ }^{27}$ Neatby and McEown contextualize unionization in terms of the broader trends in Canadian society

\footnotetext{
${ }^{25}$ Between 1963 and 1976, Neatby published three books on the careers of Canadian prime ministers Wilfrid Laurier and William Lyon Mackenzie King as well as a history of Canada's experience during the economic depression of the 1930s.

${ }^{26}$ Peter Burke, "Overture. The New History: Its Past and its Future," in New Perspectives on Historical Writing, $2^{\text {nd }}$ ed., ed. Peter Burke (University Park, Pennsylvania: Pennsylvania State University Press: 2001), 3-4.

${ }^{27}$ Ibid.
} 
such as shifts in public policy, weave the recollections of employees into their narrative, explore briefly the effect of gender relations on female faculty in the 1970s, and feature female non-academic administrators in a photo gallery. Nonetheless, their analysis of university-based collective action seems incomplete. Neatby and McEown only raise, but do not address, the issues of class and status. They do not broaden their argument to include the possibility that unionization could be interpreted as being more meaningful than just a generalized reaction to a particular social and economic context. Moreover, they narrow their focus to one occupational group — professors - making only passing reference to the participation of librarians in the certification of CUASA, and ignoring the experience of the support staff employees who certified in the same period. Other historians of higher education explore these topics more fully, as do some historians interested in labour, librarianship and women's work.

The history of Canadian university-based unions is to be found mainly in the studies of individual institutions - universities, academic staff associations or librariesdone by historians of higher education and librarianship. A small sample of these histories suggests that, like Neatby and McEown, these scholars use an approach that is a hybrid of "old" and "new" historiographies wherein unionization is just one event that occurs during the life of an institution and individuals are instrumental in effecting historical change. ${ }^{28}$ These institutional histories are placed in their social, economic, and

${ }^{28}$ I sampled the institutional histories currently in the Carleton University Library collection. My survey includes the histories of Simon Fraser University, Mount Allison University and McGill University as well as the Universities of Saskatchewan, Alberta, Manitoba, Toronto and Guelph. In addition, I included two doctoral theses that study faculty unionization. Stefan Jensen provides a more comprehensive overview in his thesis on the faculty unionization at St. Mary's University, the first group to be formally recognized in English Canada and Joy Bennett explores unionization at three Canadian Anglophone universities: the University of Manitoba, Dalhousie University and Queen's University. Jensen, Stefan. "Dodging the Steamroller: The Unionization of Professors at Saint Mary's University, 1963-79" (doctoral thesis, Memorial University of Newfoundland, 2008), accessed March 3, 2010, 
political contexts, and scholars do not rely solely on written evidence but use a wider range of sources that may include oral history interviews from faculty who participated in unionization. For example, in Evolution of the Heart. A History of the University of Toronto Library Up to 1980 (published in 1989), retired University of Toronto (U of T) Chief Librarian Robert H. Blackburn places the collective action of academic librarians and library support staff within a set of environmental conditions that contributed to strains in the workplace, using personal documents such as journal entries and letters. ${ }^{29}$

Blackburn's book blends institutional history and with the genre of memoir, as does William H. Nelson's history of the University of Toronto Faculty Association (UTFA), written in $1993 .{ }^{30}$ Blackburn bases his account of library development on his experiences as the chief librarian, and he recounts these years in the first person. As a long-time member of the UTFA, and its president from 1973 to 1976, Nelson participated directly in the key events and issues in the period when certification was being debated and he gives a personal account of his experiences against the backdrop of the socioeconomic and political environment of Ontario, as did Neatby and McEown. In The Search for Faculty Power. The University of Toronto Faculty Association 1942-1992, he recounts the debates on unionization that led to the UTFA seeking and gaining voluntary

http://search.proquest.com/docview/304404637?accountid=9894. Joy Bennett, "From Gentlemen's Agreements to Collective Agreements: How the Unionization of Full Time Faculty Members in Anglophone Canadian Universities has Changed the Management and Governance Structures of those Universities" (doctoral thesis, Concordia University, 1992), accessed March 1, 2010, http://search.proquest.com/docview/305133345?accountid=9894. (305133345). In addition, I included Robert H. Blackburn's history of the University of Toronto Library as well as William Nelson's history of the U of T faculty association and William Bruneau's account of the development of the University of British Columbia's faculty association.

${ }^{29}$ Robert H. Blackburn, Evolution of the Heart. A History of the University of Toronto Library Up to 1981 (Toronto: University of Toronto Library, 1989).

${ }^{30}$ Blackburn, Evolution of the Heart; William. H. Nelson, The Search for Faculty Power. The University of Toronto Faculty Association 1942-1992 (Toronto: The University of Toronto Faculty Association, Canadian Scholars' Press, 1993). See also Robin Ross, The Short Road Down. A University Changes (Toronto: University of Toronto Press, 1984). Ross describes this book as personal account of the University of Toronto between 1958 and 1982, when he acted as the university registrar. 
recognition as the faculty bargaining agent in 1977 . Nelson does not footnote any of his sources, and he offers his own opinion on issues and people, often referring to his university colleagues by their first names "for the sake of immediacy and a kind of authenticity." 31 Such approaches are interesting in that they produce histories that read as a combination of fact and memories. They are placed in a somewhat "liminal space" between history and personal account and thus are not only factual but offer the additional benefit of insights into the lived experiences of individuals who participated directly in a particular set of historical events. These historical accounts are also unusual in that both authors discuss the involvement of academic librarians in the collective action of the UTFA whereas other histories typically do not. Blackburn's inclusion of the activities of his staff is logical in an account of the development of the university library but Nelson's inclusion is refreshing, given that this female-dominated occupation is usually invisible in the histories of universities.

Another notable step away from old political history amongst institutional histories is Paul Axelrod's history of higher education in Ontario, Scholars and Dollars: Politics, Economics, and the Universities of Ontario $1945-1980 .{ }^{32}$ His focus is the ideology and culture of universities; moreover, he has not written a "biography" that celebrates the progress of higher education or a single institution. Explicitly moving beyond the traditional narratives such as those of "struggle and survival," Axelrod is interested in understanding the social role of the university within "a context broader, less

\footnotetext{
${ }^{31}$ Nelson, Search for Faculty Power, 1.

${ }^{32}$ Paul Axelrod, Scholars and Dollars: Politics, Economics, and the Universities of Ontario 19451980 (Toronto, Buffalo, London: University of Toronto Press, 1982).
} 
idealistic, and more critical than that of the traditional historiography. ${ }^{, 33} \mathrm{He}$ has produced what he calls a "political economy" of provincial universities and this research has been cited in several histories of Canadian faculty unionization including Creating Carleton, perhaps because Axelrod specifically discusses the case of unionization at Carleton in greater depth and contextualizes the certification of CUASA to some extent in terms of the broader labour movement.

Nevertheless, as mentioned previously, the vast majority of this historical research privileges the collective action of professors, arguably the most privileged occupational group on university campuses; the histories of academic librarians and non-academic support staff are sparse. Charlotte Mudge's short overview of librarians and collective bargaining in Canada includes some discussion of academic librarians, while, as mentioned earlier, University of Toronto librarians and support staff members receive the greatest attention of all university histories. ${ }^{34}$ Glen Makahonuk's history of the 1974 strike by members of the University of Saskatchewan Employees' Union also briefly details the formation of this union in 1944, which occurred just after the Saskatchewan government introduced legislation that allowed provincial public sector workers to unionize. However, Canadian academic clerical, administrative and technical workers are otherwise neglected. ${ }^{35}$ Some discussion of this employee category occurs in the American

${ }^{33}$ Ibid., 4. Axelrod does depend, however, on Carleton graduate Debra Mair's unpublished thesis for his discussion of faculty unionization at Carleton. Mair's work is discussed in the historiography section in this chapter.

${ }^{34}$ Charlotte R. Mudge, "Collective Bargaining of Librarians in Canada: Issue and Concerns," Argus 1, no. 3/4 (Mai-Juin-Juillet-Aout, 1982): 91-6. See Blackburn, Evolution of the Heart; Nelson, Search for Faculty Power; and Ross, The Short Road Down, for references to the unionization University of Toronto librarians and support staff.

${ }^{35}$ Glen Makahonuk, "In Union is Strength": The University of Saskatchewan Employees' Union Strike of 1974," Saskatchewan History 48, no. 1 (Spring 1996): 30-43. Some employees were frustrated with poor working conditions and eight men in the power plant took the initiative to approach the Canadian Congress of Labour to support the certification of the University of Saskatchewan Employees Association. 
library, feminist and economics literature although the studies are limited in number.

Likewise, a few articles exist that provide accounts of the unionization of clerical workers at U.S. universities including those at Yale, Columbia and the University of Rhode Island. ${ }^{36}$ In addition, there are several published accounts of the unionization of academic library staff. ${ }^{37}$ Typically, however, this research does not examine the causes of union formation.

Like Neatby and McEown, other historians explain faculty union formation in terms of environmental factors that had both "'global' and 'local' dimensions." ${ }^{38}$ All argue that the macroeconomic conditions of the 1960s and 1970s were crucial to determining collective action at Canadian universities, including Carleton; the years of "limitless expansion [being] replaced by ... limitless contraction" took their toll on many institutions and led not only to a real decrease in salaries but also a fear of job layoffs. ${ }^{39}$ Although faculty unionization is most typically linked to the financial stringency of the 1970s, Blackburn's account also placed the collective action of U of T librarians in the context of the economic environment and links the activism of support staff to two distinct factors. Blackburn attributes union formation to the presence of a new generation of library workers that was hired during the earlier period of economic prosperity but "felt little connection" to the institution. In addition, he blames the politics of the 1960s

\footnotetext{
${ }^{36}$ See Linda L. Anderson, "On Strike against Yale University," Frontiers: A Journal of Women Studies 8, no. 3, Tenth Anniversary Issue: The Women's Studies Movement: A Decade Inside the Academy (1986): 26-32; Richard W. Hurd, "Learning from Clerical Unions: Two Cases of Organizing Success," Labor Studies Journal 14, no. 1 (Spring 1989): 30-51. Gail Gregory Sansbury, “'Now What's the Matter with you Girls?' Clerical Workers Organize," Radical America 14, no. 6 (1980): 67-75.

${ }^{37}$ See for example, Leo Nelson Flanagan, "Sleeping Giant Awakes: The Unionization of Library Support Staffs," Wilson Library Bulletin 48, no. 6 (February 1974): 491-99; Mark Weber, "Support Staff Unions in Academic and Public Libraries: Some Suggestions for Managers with Reference to the Ohio Experience, 1984-1990," Journal of Library Administration 17, no. 3 (1992): 65-86.

${ }^{38}$ Ibid., 205.

${ }^{39}$ Axelrod, Scholars and Dollars, 205.
} 
that led to the presence of "radical student groups" on campus who then "plant[ed] union organizers" in the library who, in turn, were able to leverage a lack of loyalty in the new cohort of staff. $^{40}$

Locally during the early 1970s, professors across Ontario and Canada were concerned about a range of issues related to salaries, benefits and other working conditions such as pensions, tenure and academic freedom. However, faculty experienced the impact of the financial crunch to varying degrees and, accordingly, their staff association representatives focused their attention on the problems most relevant to their own campuses. Salaries may not have been an issue at Carleton where professors were more concerned about job security but, at the University of Toronto, "for twenty years the faculty association's main concern had been to influence salary settlements." ${ }^{41}$ Some of these differences might also have been due to the relative financial stability of "senior" institutions such as Queen's in comparison to the vulnerability of newer schools and presumably these issues could have also been important to librarians, who either joined or tried to join faculty associations. ${ }^{42}$ Neither the Canadian nor the American literature on university support staff unions identifies specifically the financial hardships of the 1970s as the cause for collective action, although American universities experienced similar retrenchment. ${ }^{43}$ However, chronically low salaries and poor benefits are cited as reasons for unionization. ${ }^{44}$

${ }^{40}$ Blackburn, Evolution of the Heart, 303.

${ }^{41}$ Nelson, Search for Faculty Power, 71; Axelrod, Scholars and Dollars, 207; see also Bennett, "From Gentleman's Agreements to Collective Agreement."

${ }^{42}$ According to Jensen in "Dodging the Steamroller," librarians at St. Mary's University, one of the first Anglophone Canadian universities to certify, were denied membership in the faculty association.

${ }^{43}$ See for example, Judith DeCew, Unionization in the Academy: Visions and Realities (Lanham, Maryland: Rowman and Littlefield, 2003).

${ }^{44}$ See for example Gregory Sansbury, ““Now What's the Matter with you Girls?” and Flanagan, "A Sleeping Giant Awakes." 
There is also consensus amongst Canadian historians that the restrictive systems of governance at universities in Canada were also critical to sparking faculty collective action across the country. Inadequate faculty participation in university decision-making had been an issue at Canadian universities since the 1950s. Although the 1966 Duff Berdahl report on university governance had recommended faculty representation on university governing bodies, professors' dissatisfaction was persistent as some institutions were slow to implement the recommended changes. ${ }^{45}$ In addition, the "massive expansion" of the 1960s was accompanied by increased bureaucratization at Canadian universities, which meant that generally more senior managers were hired, new administrative processes were created, and professors became (more) alienated from senior staff including the president. ${ }^{46}$ At the local level, these changes were partly responsible for tensions between individual presidents, governing boards and faculty. Michael K. Oliver faced faculty dissent; John Evans at the U of T was "alienated" from professors; and faculty and senior administrators as well as the Board of Governors at the University of Saskatchewan were locked in a polarized relationship. ${ }^{47}$ Other broad environmental determinants could include the legacy of radical politics from the sixties,

\footnotetext{
${ }^{45}$ In 1964, Sir James Duff and Professor Robert O. Berdahl were commissioned by the Canadian Association of University Teachers and the Association of Universities and Colleges of Canada to study the current systems of university governance at Canadian universities. Canadian academics had been dissatisfied with their restricted role in university decision-making for some time and the two commissioners were tasked to look at the current models and make recommendations to improve governance structures. James Duff and Robert O. Berdahl, University Government in Canada. Report of a Commission Sponsored by the Canadian Association of University Teachers and the Association of Universities and Colleges of Canada (Toronto: University of Toronto Press, 1966). Axelrod, Scholars and Dollars, 206.

${ }^{46}$ Axelrod, Scholars and Dollars, 205. See also Mudge, "Collective Bargaining of Librarians."

${ }^{47}$ Nelson, Search for Faculty Power, 75. Michael Hayden, Seeking a Balance. The University of Saskatchewan 1907-1982 (Vancouver: University of British Columbia Press, 1983), 271.
} 
the unionization of other white-collar workers, the rise and fall in the both the supply of and demand for academics during the 1960s and, in the case of female staff, sexism. ${ }^{48}$

These histories appear to take what British sociologist Rosemary Crompton has called the industrial relations approach to unionization. Crompton, who wrote extensively on a number of theoretical topics including class and applied her ideas to the study of unionism, explains this form of collective action as "a pragmatic reaction to specific circumstances" 49 - although the word pragmatic may not be entirely accurate given the intensity of the feelings faculty experienced at Carleton and other universities during this process. While each account features a set of socioeconomic and political determinants of unionization, most appear not to have identified these factors within a formal explanatory framework. In contrast, scholars in other disciplines have identified critical environmental factors related to unionization in English-Canadian universities and base their work on a variety of analytic models. ${ }^{50}$ In particular, Debra Mair developed a set of criteria for determining the probability of collective action based on selected theories of collective behaviour and conflict group formation and tested its viability using the case of faculty unionization at Carleton. ${ }^{51}$

For her 1977 master's thesis in sociology entitled Unionization and the Middle Class: The Case of University Faculty, Mair drew upon the work of social conflict

${ }^{48}$ Anderson, "On Strike against Yale University."

${ }^{49}$ Rosemary Crompton, “Approaches to the Study of White-Collar Unionism," Sociology 10, no. 3 (September 1976): 411-12.

${ }^{50}$ See for example Bennett, "From Gentlemen's Agreements." Bennett draws upon the work of American political scientists Robert K. Carr and Daniel K. Van Eyck who proposed in 1973 that faculty would take collective action to unionize under three conditions: one, a legal framework for collective bargaining would exist; two, there would be significant dissatisfaction with current employment conditions; and three, someone (or some organization) would be available and willing to organize. ${ }^{50}$ In addition to these conditions, Bennett argues that professors must also be concerned about both academic and economic stability.

${ }^{51}$ Debra Mair, “Unionization and the Middle Class: The Case of University Faculty” (master's thesis, Carleton University, 1977). 
theorists, particularly German-British sociologist Ralf Dahrendorf and American sociologist Neil Smelser, to argue that the probability of middle class collective action would be determined by the presence or absence of six specific conditions: the perception of strain (i.e., social, economic and political contradictions); structural conduciveness (including alternative methods for handling grievances and the ability to communicate); ideology (how the situation was interpreted), situational triggers; mobilization and social control (i.e., any individual or institutional response that serves to reduce or eliminate the probability of collective action). When she applied this model to the unionization of professors at Carleton, she discovered that the first five conditions were present to a high degree and that there was little or no counter response to prevent the certification of CUASA. Although she does not identify any given factor as preeminent, she does provide a systematic approach to understanding the causes of university-based unionization..$^{52}$

When historians of higher education attribute the formation of unions at EnglishCanadian universities to key social, political and economic factors, typically they limit their focus to faculty members and their analysis to a single theoretical framework. Thus it is unclear which conditions might have had the greatest impact, either broadly or in individual cases; sometimes they seem to slip "into a necessarily inconclusive summary of current events and [tremble] on the edge of mere prediction. ${ }^{, 53}$ Nonetheless, some historians of academia are willing to suggest that the collective action of professors

\footnotetext{
${ }^{52}$ Interestingly, Neatby and McEown do not cite her research although their book was published twenty-five years after she finished her thesis; Axelrod does draw upon Mair's work in Scholars and Dollars.

${ }^{53}$ Nelson, Search for Faculty Power, 161.
} 
represents an on-going "search" for workplace power. ${ }^{54}$ Ultimately, all agree at least that faculty members were struggling for a greater share of institutional decision-making authority over the distribution and use of university resources, to ensure that they were "not left behind." 55 Their conceptual underpinnings are twofold. Power is being defined in the classic Weberian sense of power over others or "the chance of a man or of a number of men to realize their own will in a communal action even against the resistance of others who are participating in the same action." 56 They also assume that individuals or groups are the architects of historical change.

Neatby and McEown make one conclusive statement about the certification of the faculty association at Carleton University: professors did not respond to class-based arguments in favour of unionization. Other historians of higher education agree with this interpretation. None use class as a category of analysis when studying the formation of faculty unions nor do any seem to label faculty as white-collar workers, with the exception of Axelrod who bluntly argues that those academics advocating for certification presented this form of collective action as a strategy that would "uphold, not overturn, academic traditions and university conventions" - that is, professors were not proletariats. ${ }^{57}$ Given that Axelrod used Mair's study as a source for his analysis, it is not surprising to learn that Mair arrives at the same conclusion. The purpose of her thesis is to explain the emergence of academic unions, and she argues that class is irrelevant

\footnotetext{
${ }^{54}$ Ibid.

55 J.M. Bumsted, The University of Manitoba: An Illustrated History (Winnipeg: University of Manitoba Press, 2001), 182. E-book.

${ }^{56}$ Max Weber, From Max Weber: Essays in Sociology, trans. and ed. H. H. Gerth and C. Wright Mills (New York: Oxford University Press, 1958), 180.

${ }^{57}$ Axelrod, Scholars and Dollars, 210.
} 
because Marxist and Weberian class-based theories do not adequately explain the collective action of middle class workers. ${ }^{58}$

Such approaches amongst historians of academia are very different from those of labour historians whose work has long been synonymous with the study of unions in Canada. While these scholars would agree that the workplace is a site of "power and privilege," 1960s interprets unionization as a conflict that reflects the inherently antagonistic and persistent struggles between employers and the employees they exploit. ${ }^{60}$ Even occupational groups not traditionally engaged in this form of resistance- such as academics — can be analyzed within this framework. It can be argued that labour historians are defining historical transformation in structural terms i.e., as the result of social structures, or what Australian sociologist of gender R.W. Connell refers to as “enduring or extensive patterns among social relations." ${ }^{61}$ In this context, class is a social structure and so too is gender, which has been defined as social interaction based on "physical differences linked to reproduction" rather than economics. ${ }^{62}$ Canadian feminist historians have also produced a significant body of scholarly literature on unions using both class and gender as categories of analysis. For them, the workplace is a site of male power and privilege where women are doubly exploited as a result of the sexual division of labour. Unionization is a form of female resistance. ${ }^{63}$

\footnotetext{
${ }^{58}$ See, for example, Mair, "Unionization and the Middle Class."

${ }^{59}$ Gillian Creese, Contracting Masculinity. Gender, Class and Race in a White-collar Union, 19441994 (Don Mills: Oxford University Press, 1999), 3.

60 John Benson, "Canadian Labour History," Bulletin-Society for the Study of Labour History 51, no. 1 (1986): 18-24.

${ }^{61}$ R.W. Connell, Gender, (Cambridge: Polity Press, 2002), 9.

${ }^{62}$ Creese, Contracting Masculinity, 3.

${ }^{63}$ See for example, Heather Jon Maroney and Meg Luxton, eds., Feminism and Political Economy. Women's Work, Women's Struggles (Toronto: Methuen, 1987); Alison Prentice, Paula Bourne, Gail
} 
Canadian labour history since the mid-1960s has been heavily influenced by the work of British Marxist historian E.P. Thompson, in particular his landmark 1963 history of the formation British working classes during the $17^{\text {th }}$ and $18^{\text {th }}$ centuries. ${ }^{64}$ Thompson's analytic framework contains what British Marxist scholar Richard Hyman calls the three central propositions of Marx's theory of class:

Social relations within production are the most fundamental determinant of class structure; ... classes derive their definition and identity from the relationships between them; ... the relationship of antagonism between classes is the most important motor of social transformation. ${ }^{65}$

According to Thompson, class is a relationship that unfolds over a relatively long period of time as individuals identify that they share similar interests with some people and oppose the interests of other groups. While he argued that "the class experience is largely determined by the productive relations into which men are born," ${ }^{66}$ it is also a dynamic relationship made by "real people in real contexts"67 and expressed culturally (e.g., through ideas, values, traditions, language). As such, class may be a different experience for different people at different times. Meanwhile, an unequal distribution of resources and social power is inherent to the antagonistic relationship between groups such as the English working and capitalist classes. Social change occurs as "men ... live their own history," consciously responding to the exploitation caused by these inequalities. ${ }^{68}$ This definition of class provided a renewed framework for labour scholars to study historical

Cuthbert Brandt, Beth Light, Wendy Mitchinson and Naomi Black, Canadian Women. A History (Toronto: Harcourt Brace Jovanovich, 1988); Linda Briskin and Lynda Yatz, eds., Union Sisters. Women in the Labour Movement (Toronto: The Women's Educational Press, 1983).

${ }^{64}$ E. P. Thompson, The Making of the English Working Class (Hammondsworth, England: Penguin 1963).

${ }^{65}$ Richard Hyman, "White-Collar Workers and Theories of Class," in Richard Hyman and Robert Price, eds., The New Working Class? White-Collar Workers and Their Organizations (London: The MacMillan Press Ltd, 1983), 16.

${ }^{66}$ Thompson, The Making of the English Working Class, 10.

${ }^{67}$ Ibid., 9.

${ }^{68}$ Ibid., 12 . 
change by asking questions about working class formation in Canada, and they

concentrated mainly on the development of class consciousness and forms of resistance such as unionism. For these new labour historians as for their predecessors, class had "the weight of world historical transformation" squarely on its shoulders. ${ }^{69}$

The second wave of this alternative scholarship developed in the mid- to late 1970s partially in the wake of the North American women's and civil rights movements and, again, partly as a result of Thompson's work that encouraged historical research on marginalized peoples such as the industrial working class, or "history from below." ${ }^{\text {70 }}$ As a result, scholars began to study individuals and groups that had typically been left out of the historical record. For example, feminist historians wrote the stories of women and social historians started to study the experiences of individuals or groups from non-white English Canadian backgrounds. These scholars generally questioned the relevance of class as the pre-eminent category of analysis: economic interests were not necessarily the cornerstone of social and political identity and therefore of historical change. Identities based on gender, race and sexual orientation were equally or more relevant and historians debated the importance of these social structures; thus class analysis fell out of favour in many areas of historical research. As Canadian labour historian Joan Sangster wrote in 2000, "neither the political or theoretical context in recent years has been propitious for either class or materialist analyses." ${ }^{71}$

\footnotetext{
${ }^{69}$ Stanley Aronowitz, The Politics of Identity. Class, Culture, Social Movements (New York, London: Routledge, 1992), 11.

${ }^{70}$ Thompson, Making of the English Working Class, 12. Thompson does not actually use this phrase but refers to those of whom he will be writing and rescuing such as "the stockinger."

${ }^{71}$ Joan Sangster, "Feminism and the Making of Canadian Working-Class History: Exploring the Past, Present and Future," Labour / Le Travail 46, Special Millennium Issue (Fall 2000): 154. See also, Stanley Aronowitz, How Class Works. Power and Social Movement (New Haven and London: Yale University Press, 2003), 2. Natalie Zemon Davis, "Women's History" in Transition: The European Case," Feminist Studies 3, no. 3/4 (Spring-Summer 1976): 83-103.
} 
Partly as a response to this critique, many labour historians integrated concepts of gender and race into their analyses and the definition of working class was enlarged. Earlier scholarship had narrowly defined the "productive" class as male manual, unskilled or semi-skilled industrial workers i.e., blue-collar labour. ${ }^{72}$ Now scholars began to record the histories of organized male and female workers from a variety of backgrounds employed in a wide range of occupations and economic sectors. ${ }^{73}$ Particular attention was paid to exploring whether the "allegedly inherent traits of womankind" had actually prevented woman from being militant unionists. ${ }^{74}$ For example, Joan Sangster wrote about striking female telephone operators in Toronto in the early $20^{\text {th }}$ century and American historian Alice Kessler-Harris's 1975 article, "Where are the Organized Women?," challenged the "typical" conclusion that women are difficult to organize; women might have faced barriers to unionization, but "they were clearly not insurmountable barriers." $" 75$

Despite the broadening definition of working class, white-collar unions have generally received less attention than their blue-collar counterparts. ${ }^{76}$ Overviews such as Craig Heron's "short history" of the Canadian labour movement, as well as studies of

\footnotetext{
72 John Porter, The Vertical Mosaic. An Analysis of Social Class and Power in Canada, (Toronto: University of Toronto Press, 1965), 308. Like the definition of white-collar work, the definition of bluecollar work can vary, although it typically refers to work done by those employed in industrial production or manufacturing.

${ }^{73}$ Bryan D. Palmer and Joan Sangster, Labouring Canada. Class, Gender and Race in Canadian Working-Class History (Don Mills: Oxford University Press, 2008). See for example, Alice Kessler-Harris, "Where are all the Organized Women Workers?," Feminist Studies 3, no. 1/2 (Autumn 1975): 92-110; Donica Belisle, "Exploring Postwar Consumption: The Campaign to Unionize Eaton's in Toronto, 19481952," The Canadian Historical Review 86, no. 4 (December 2005): 641-72; Kathleen M. Barry, "Too Glamorous to Be Considered Workers": Flight Attendants and Pink-Collar Activism in Mid-TwentiethCentury America," Labor: Studies in Working Class History of the Americas 3, no. 3 (Fall 2006): 119-38.

${ }^{74}$ Ruth Frager, "No Proper Deal: Women Workers and the Canadian Labour Movement, 1870-1940" in Women in the Labour Movement, eds. Briskin and Yanz (Toronto: Women's Press, 1983), 44.

75 Joan Sangster, "The 1907 Bell Telephone Strike: Organizing Women Workers," Labour / Le Travail, 3 (1978): 109-30; Kessler-Harris, "Where are all the Organized Women Workers," 93.

${ }^{76}$ Desmond Morton, "Some Millennial Reflections on the State of Canadian Labour History," Labour / Le Travail 46 (Fall 2000): 11-36.
} 
individual unions such as the clerical union at B.C. Hydro and the Canadian Union of Postal Workers begin to address this gap in the literature. ${ }^{77}$ The primary focus of this historical research is on unions in the public sector rather than the private or "para-public" unions, perhaps because the majority of white-collar workers who unionized in the 1960s and 1970s were federal and provincial government employees. ${ }^{78}$ In addition, the scope of some studies has been narrowed to union activities after certification rather than the events or factors that led to unionization. ${ }^{79}$

In his Marxist-based interpretation of the formation of Canadian white-collar unions, Heron argues that Canadian white-collar employees in the public and private sectors have historically not "embraced" unions for economic and ideological reasons. At the turn of the $20^{\text {th }}$ century, he suggests that these workers did not unionize because by having relatively "clean," secure, well paying jobs, they "felt smugly superior to bluecollar unionists"; by implication they did not identify with working class interests. ${ }^{80}$ When civil servants working for the federal and provincial governments formed staff associations, they were open to all employees, including those in management positions. Occasionally staff associations might advocate for changes to terms and conditions of work but such activities constituted "collective begging" (to use Heron's words) not collective bargaining.

\footnotetext{
${ }^{77}$ Craig Heron, The Canadian Labour Movement. A Short History, $2^{\text {nd }}$. ed. (Toronto: James Lorimer \& Company, 1996); Creese, Contracting Masculinity; Julie White, Mail \& Female. Women and the Canadian Union of Postal Workers (Toronto: Thompson Educational Publishing, Inc., 1990); Kendra Coulter, "Unionizing Retail: Lessons From Young Women's Grassroots Organizing in the Greater Toronto Area in the 1990s," Labour / Le Travail 67 (Spring 2011): 77-93.

${ }^{78}$ Heron introduces the term para-public his discussion of white-collar unions in The Canadian Labour Movement, 97. Although he does not clearly define this term, he seems to suggest that para-public workers are employed by organizations such as schools and hospitals that are publicly funded but operate to some degree at arm's length from government.

${ }^{79}$ For example, Creese, Contracting Masculinity and White, Mail \& Female.

${ }^{80}$ Heron, Canadian Labour Movement, 95 and xi. In his introduction, Heron defines the Canadian working class broadly as "skilled, white English-speaking male workers" doing paid work.
} 
In contrast, according to Heron, civil servants became more conscious of changes in their socioeconomic standing and their militancy began to build by the mid- to late $20^{\text {th }}$ century. Their economic position and "superior social status" ${ }^{\prime 1}$ were being threatened by the success that blue-collar unions were having in their negotiations for improved wages and terms of employment for their members. By the 1960s, public sector workers were "seething": not only did they perceive an on-going deterioration in their terms and conditions of employment relative to those of unionized workers, but also managers were actively trying to reduce wages in an effort to diminish the cost of the public sector in general. In response, civil servants began demanding the right to collective bargaining, a right that governments had not granted in the past. Such pressure resulted in the passage of the federal Public Service Relations Act in 1967 as well as similar provincial legislation, and public sector workers began to win the legal right to bargain through their unions. These unions included large "centralized" organizations such as the Public Service Alliance of Canada (PSAC) and, in some cases, were created by certifying existing staff associations (e.g., CUASA).

In the wake of the formation of public sectors unions, employees in para-public organizations, who Heron defines as "less skilled clerical and manual workers" or professionals, employed by municipal governments or other publicly funded institutions such as hospitals, libraries and universities, unionized in greater numbers. ${ }^{82}$ Manual and clerical workers who also resented the erosion of their terms and conditions of work often chose to join the Canadian Union of Public Employees (CUPE). Professional workers, such as librarians and professors, "middle class" employees "annoyed" by a loss of

\footnotetext{
${ }^{81}$ Ibid., 96.

${ }^{82}$ Ibid., 97. It is important to note that workers in some "para-public" organizations such as Canadian public libraries had begun to unionize earlier in the $20^{\text {th }}$ century.
} 
occupational prestige, followed a pattern similar to that of civil servants and often sought certification for their existing staff associations, rather than joining CUPE. Likewise, they refrained from participation in the broader Canadian labour movement, which they associated with blue-collar, working class interests.

Other historians provide a similar chronology of public and para-public union formation but Heron's analysis is the most useful because he suggests factors that could have influenced the unionization of white-collar workers at Carleton in the 1970s. ${ }^{83}$ However, his interpretation of white-collar unionism presents some analytic challenges. For example, his definitions of white-collar work, of its place in class relations and "consciousness" can seem contradictory. Whilst white-collar work is clean, secure and distinct from blue-collar manual labour, it can also be relatively unskilled and manual, or relatively skilled and professional. It is generally accepted that the label white-collar refers to a heterogeneous category of labour, but Heron does not clarify the terms of coexistence of manual and non-manual labour. ${ }^{84}$ In addition, he does not delineate the specific nature of the work of civil servants enough to indicate, as other scholars have shown, that federal public servants had a workplace culture that was different from that of private sector organizations, in ways that were important for the formation of unions such as PSAC. ${ }^{85}$ Neither does he fully allow for the fact that while some of the whitecollar workers who unionized, such as clerical staff, were concerned with deteriorating incomes and identified with the working class, others such as librarians, worried about

\footnotetext{
${ }^{83}$ Creese, Contracting Masculinity. According to Creese in the 1940 s office staff at B.C. Hydro turned their staff association into a union in response to a profound dissatisfaction with terms and conditions of work as well as a shift in status relative to blue-collar company workers.

${ }^{84}$ See, for example, Benjamin Solomon and Robert K. Burns, "Unionization of White-Collar Employees. Extent, Potential, and Implications," The Journal of Business 36, no. 2 (April 1963), $141-65$.

${ }^{85}$ Rosemary Warskett, "Learning to be 'Uncivil': Class Formation and Feminisation in the Public Service Alliance of Canada, 1966-1996" (doctoral thesis, Carleton University, 1998).
} 
occupational prestige and continued to associate themselves with the middle class, even after unionizing.

These ambiguities make it difficult to discern a coherent explanation for whitecollar unionization. They reflect three of the central conceptual problems related to the study of this form of union: the definition of non-productive work; the definition of the middle class; and the link between middle class consciousness and white-collar unionism. As Hyman points out in an essay entitled White-Collar Workers and Theories of Class, scholars have a longstanding tradition of categorizing occupations as either manual or non-manual in order to understand the differences between workers in industrial capitalist economies. ${ }^{86}$ Manual labour is physical and done by those workers employed directly in industrial production wearing "blue-collars," whereas non-manual labour is intellectual and done by those employed in non-production jobs wearing "white-collars." Most Marxist theorists had traditionally posited that these occupational differences were synonymous with class divisions and collective action. In their understanding, manual workers are working class and, under the right circumstances, will mobilize to protect their economic interests while non-manual employees, who are middle class, have different economic interests and will not act collectively under any circumstance. However, Hyman argues that the growth in white-collar work and white-collar unions in the $20^{\text {th }}$ century seemed to contradict "Marx's class prediction of class polarization" as new forms of the middle- or working class seem to be emerging. Hyman argues more generally that "any notion of a rigid demarcation between mental and manual work is arbitrary and artificial ${ }^{\prime 87}$ while Heron seems to favour clear-cut boundaries. ${ }^{88}$

\footnotetext{
${ }^{86}$ Hyman, "White-Collar Workers and Theories of Class," 3.

${ }^{87}$ Ibid., 4-5.
} 
Perhaps, as American sociologist Stanley Aronowitz argues, the most important shortfall may be that some Marxist accounts (of which Heron's is one example) reduce "the multiplicities of concrete relations ... of identities of individuals and collectivities" to the inherently antagonistic relationship between labour and capital, and thus might underestimate the significance of other factors such as gender in shaping social relations in the workplace. For example, Heron does not fully acknowledge that a significant proportion of the white-collar workers who participated in the formation of public and para-public unions in Canada were women. Nor does he explore the connection between gender and either the class position or consciousness of these workers.

Canadian sociologist Gillian Creese agrees that workplace relationships should not be reduced to a "binary tale of class-based opposition and solidarity." ${ }^{, 99}$ Her history of unionized office workers at British Columbia Hydro and Power Authority ("B.C. Hydro"), a public sector organization, explores how work life is negotiated and made meaningful through the interaction of a variety of social structures. Creese uses feminist and postcolonial theories to inform her research, and the Office and Professional Employees' International Union (OPEIU) Local 378 offers a case study to explore the role trade unionists play in the process by which work is both gendered and racialized. ${ }^{90}$ While most of her analysis is focused on the period after the union was formed, there is a chapter that discusses the period leading up to certification.

${ }^{88}$ Hyman provided an overview of his work in "Will the real Richard Hyman please stand up?," Capital \& Class 36, no. 1: 151-64, doi: 10.1177/0309816811431875 c\&c.sagepub.com.

${ }^{89}$ Creese, Contracting Masculinity, 2.

${ }^{90}$ Creese's analysis includes the "whiteness" of the B.C. Hydro workforce and how this factor influenced the division of labour at the organization. While unionization at Carleton University could also be analyzed in terms of race, I have chosen not to address this issue and thus do not include this element in my summary of her analysis. 
Creese uses a rich variety of primary and secondary sources including interviews with union activists and OPEIU archival documents to show a path to unionization that parallels that of Heron's civil servants and para-public employees to some extent. Whitecollar office employees unionized partly in response to the deterioration of their privileged socioeconomic position as middle class workers. Unionization was facilitated by legal bargaining rights but did not represent a fundamental shift in workplace identity. Instead, forming a union was a strategy to protect their status relative to their blue-collar working class co-workers. However, Creese argues that notions of class are unstable, and that they cannot alone explain this case of union formation. Scholars who assume that work-related identities are fixed can only understand the significance of white-collar unions in terms of changes to class location and consciousness when in fact, she argues, the "meanings attached to distinctions between white- and blue-collar work change historically, as do the jobs so classified, and these meanings are mediated within the workplace and civil society." 91 In particular, workers are constantly negotiating the gendered nature of their jobs, and the study of unionization can illuminate this process.

In the case of clerical workers at B.C. Hydro, forming a union "was bound up with negotiating meanings of working-class masculinity." 92 In the late $19^{\text {th }}$ and early $20^{\text {th }}$ centuries, clerical work in Canada had been transformed from "men's work" to "women's work." 93 As a result, by the mid- $20^{\text {th }}$ century most clerical staff were women who did work designated as feminine and thus stereotyped as routine, detailed oriented and unskilled. Typically, these positions were relatively poorly paid and offered few

\footnotetext{
91 Ibid., 25.

92 Ibid.

${ }^{93}$ See for example, Graham S. Lowe, Women in the Administrative Revolution: The Feminization of Clerical Work (Cambridge: Polity, 1987).
} 
opportunities for advancement. In contrast to this reality, approximately $50 \%$ of clerical workers at B.C. Hydro in the 1940s were men. Even if the company offered preferential treatment to male clerical workers by giving them higher salaries for doing the same work as their female colleagues, or by hiring them for better paying jobs, this feminized work still did not conform to dominant definitions of masculinity. It was not physical enough to be generally understood as blue-collar labour, nor placed high enough on the organizational chart to be understood as managerial and middle class work. Most importantly, it did not pay a "manly" breadwinner's wage. By unionizing, these men had a vehicle through which to "masculinize" their work by negotiating higher wages and benefits as well as better working conditions.

Creese's history is particularly relevant to understanding faculty and support staff unionism at Carleton University. She has done one of the few in-depth studies of union formation amongst clerical workers, whose working and employment conditions might be similar to those of the Carleton support staff who held a variety of white-collar jobs that were identified as clerical. Her analysis also underlines the importance of considering both the feminization and masculinization of work. Scholars have well documented the feminized nature of clerical work over the $20^{\text {th }}$ century, and it would be tempting to conclude that clerical workers at Carleton unionized principally in order to improve the status of women at the university. ${ }^{94}$ However, both men and women within CUSSA supported unionization. They did not agree on "women's issues" nor did all association members vote in favour of certification. Creese's model suggests that the gendered nature of these debates could be explored for all three occupational groups.

\footnotetext{
${ }^{94}$ See Lowe, Women in the Administrative Revolution and Dee Garrison, The Apostles of Culture: The Public Librarian and American Society, 1876-1920 (New York: Free Press, 1979).
} 
Whereas the unionization of professors and clerical workers have received some attention, Canadian historians have not addressed the issue of unions and librarianshipacademic or otherwise - in any depth and certainly not in terms of social structures such as class and gender. This omission is extraordinary, particularly as librarianship is another example of an occupation that historically has been feminized. ${ }^{95}$ During the 1960s and early 1970s, female librarians were actively discussing discrimination in the workplace and considering various forms of collective action, particularly unionism and professionalism that might provide them with greater bargaining power. ${ }^{96}$ As Canadian professor of administrative studies, Carl G. Garry, pointed out in 1977, "the number of anomalies related to many years of sex discrimination against [female librarians is] ... apparent and their attempt to get some immediate redress through unionization is understandable and predictable." ${ }^{, 97}$ American historians of librarianship have started to address the feminization of library work in connection with the formation of unions. ${ }^{98} \mathrm{In}$

${ }^{95}$ Both primary and secondary sources provide ample evidence. See for example, Dee Garrison, "The Tender Technicians: The Feminization of Public Librarianship, 1876-1905," Journal of Social History 6, no. 2 (Winter 72/73): 131-59. At Carleton, 92\% of librarians were female in 1975 Geoffrey Briggs, Memorandum to President Michael Oliver on Ranking for Librarians, January 21, 1976, 3, Office of the Vice-President Academic Fonds, OVPAC-78-8, Ranking for Librarians, Carleton University Corporate Archives, Ottawa, Ontario.

${ }^{96}$ Mudge, "Collective Bargaining,” 91. Katherine Todd, "Collective Bargaining and Professional Associations in the Library Fields," Library Quarterly 55, no. 3: 288. See also Sherrill Cheda, "That Special Little Mechanism," Canadian Library Journal 31, no. 5 (1974): 422-432; Jack Hughesman, "Union Representative Looks at Librarians," Canadian Library Association Conference 1973 Proceedings, (Ottawa: Canadian Library Association, 1973). See also Suzanne Hildenbrand, "Librarian Feminism and Library Women's History: Activism and Scholarship, Equity and Culture," Libraries and Culture 35, no. 1 (Winter 2000): 51-65.

${ }^{97}$ Carl G. Garry, "The Unionization of the Profession," in Canadian Libraries in Their Changing Times, eds. Lorraine Spencer Garry and Carl Garry (Toronto: York University, The Centre for Continuing Education, 1977), 509. In the "Contributors" section of this edited volume, Garry is listed as a professor in the Department of Administrative Studies at York University. This department now seems to have been absorbed into York's Faculty of Liberal Arts \& Professional Studies.

${ }^{98}$ See for example, James W. Milden, "Women, Public Libraries, and the Library Unions: The Formative Years," Journal of Library History 12 (Spring): 150-158 and Jody Newmeyer, "The Image Problem of the Librarian: Femininity and Social Control," Journal of Library History 11, no. 1 (January 1976): 44-67. 
particular, Catherine Shanley ${ }^{99}$ has written a substantive history of the development and demise of the first U.S. public library union that makes a link between unionization and "the gendered nature of early modern librarianship."100

In The Library Employees' Union of Greater New York, 1917-1929, Shanley uses a variety of primary and secondary sources to identify the ideology, goals and tactics of the union leaders. Shanley argues that although the historical "gender conservatism" of librarians has been well established, the organization's leadership had a “feminist consciousness" which informed their commitment to unionism. ${ }^{101}$ Leaders like suffragette Maud Malone argued that female librarians and library assistants were chronically disadvantaged relative to their male colleagues due to a sexual division of labour within libraries that led to lower pay and fewer promotion opportunities for women than their male colleagues. ${ }^{102}$ While the goals of the union were similar to those of other labour organizations, the organization was "unusual" because these disadvantages were interpreted as "women's issues." ${ }^{103}$ In addition, Malone and her counionists preferred unionization to the professionalization of librarianship as a strategy for improving the status of women in library work. Generally, American library workers in the early $20^{\text {th }}$ recognized the low status of their work and in response trained librarians advocated for a greater distinction between the professional nature of their work and the clerical work done by other library staff. Union leaders argued that professionalism was elitist and would create further divisions between the better-educated librarians and

\footnotetext{
${ }^{99}$ Catherine Shanley is currently the assistant director of libraries for Manhattan College in New York City, http://guides.library.manhattan.edu/profile.php?uid=30408, accessed November 15, 2013.

${ }^{100}$ Hildebrand, "Librarian Feminism," 58.

${ }^{101}$ Ibid., 236.

${ }^{102}$ See Chapter 4 of this thesis for a discussion of the occupational boundaries between professional librarians and library technicians.

${ }^{103}$ Ibid., 240.
} 
library assistants who had less training and were already amongst the lowest paid of library workers. Instead, library staff should align themselves with the working class and fight for "equal pay for equal work" for all non-administrative employees.

Neatby and McEown observed that along with environmental factors, occupational status rather than class consciousness played a role in the formation of unions at Canadian universities in the 1970s. The case of the New York public library union confirms that job standing was important to library staff in the past, and the current literature suggests that status continued to motivate these employees as well as professors and support staff all along the second half of the $20^{\text {th }}$ century. Status also determined to some extent the relative appropriateness of different forms of collective action. Indeed, faculty members in Canada frequently opposed certification by evoking their status of as teachers, researchers and professionals. For many, only voluntary recognition was acceptable. ${ }^{104}$ Academic librarians in Ontario preferred to be members of academic staff associations rather than to belong to large public employee unions or single bargaining units that included other library staff because they wanted faculty status. ${ }^{105}$ University clerical and library staff in the United States justified unionization in terms of the low status of their work, both absolutely and in comparison to professional workers, despite the traditional images of unions as violent organizations, or as the "bastions of the macho, blue-collar male."106

\footnotetext{
${ }^{104}$ Neatby and McEown, Creating Carleton, 197; Nelson, The Search for Faculty Power, 97.

${ }^{105}$ See for example Elizabeth Hulse, "The Development of Libraries in Ontario and Their Relations with the National Library of Canada" in The National Library of Canada and Canadian Libraries: Essays in Honour of Guy Sylvestre, eds. Jean-Rémi Brault, Gwynneth Evans and Richard Paré, (Ottawa: Canadian Library Association, 1996), 103; Mudge, "Collective Bargaining of Librarians in Canada"; Garry, "The Unionization of the Profession," 510; Blackburn, Evolution of the Heart.

${ }^{106}$ See for example Anderson, "On Strike against Yale University," 26; Flanagan, "Sleeping Giants," 394; and Hurd, "Learning from Clerical Unions," 31.
} 
If historians refer liberally to the concept of status, they do not clearly define it. Synonyms such as prestige, rank or "superior standing" suggest a hierarchy of occupations, some being more important, or highly regarded, than others. Adjectives such as professional, white-collar and blue-collar do likewise. But none of the histories reviewed articulates a framework that would link the nature of occupational standing to collective action. Likewise, Mair's sociological case study of unionization at Carleton explicitly rejects status as an alternative explanation for this form of collective action. In her evaluation of class as a category of analysis for collective action, she explains that German sociologist Max Weber defined status as the ranking of individuals in terms of social honour (or prestige). Weber contended that status categories do constitute social groups that can be measured by differences in life style, such as particular customs or access to certain social benefits such as education. However, he argued that the importance of class and status varies across societies and suggested that capitalist societies are more likely to be dominated by classes than by status groups. Mair goes further, arguing that in current capitalist societies occupational hierarchies define status; ${ }^{107}$ relatively more prestigious occupations automatically lead to higher economic and social benefits (e.g., higher incomes, greater mobility, more respect). As a result, "we need only consider class, as status is merely a reflection of this."108

Mair's conclusion is problematic because status is the language that members of all three occupational groups at Carleton consistently use to describe their experiences during unionization, both at the time of union formation and in their oral history interviews. As such, any analysis of union formation at Carleton during this period

\footnotetext{
${ }^{107}$ Mair, "Unionization and the Middle Class," 44.

${ }^{108}$ Ibid., 47.
} 
should take into consideration the meaningfulness of this concept to those involved and the role it played in mobilizing support for collective action and the certification of CUASA and CUSSA. In fact, status could have played an integral role in developing occupational identity and, in turn, identity could have shaped opinions of and support for collective action, for librarians, professors and support staff as well. For example, historian William Bruneau has suggested that faculty at the University of British Columbia (UBC) have rejected unionization in part due to an inability to articulate their status as professionals. Bruneau is a former UBC faculty association president and in $A$ Matter of Identities: A History of the UBC Faculty Association 1920-1990, he frames the nature and work of a faculty association as a search for identity rather than a struggle for institutional decision-making power. ${ }^{109} \mathrm{He}$ argues that while professors identify their associations as organizations created to protect their professional interests, they still are unsure as to what "professional" means in this context. Bruneau believes that the evolution of the University of British Columbia Faculty Association, including the defeat of unionization in the 1970s, reflects this "ambiguity" in professors' definitions of their own occupational identity.

The historical literature on librarianship and unions indicates that perhaps the fiercest and most persistent debate over the relative merits of unionization and professionalization in North America took place amongst librarians. ${ }^{110}$ Librarian and

\footnotetext{
${ }^{109}$ William Bruneau, A Matter of Identities: A History of the UBC Faculty Association 1920-1990 (Vancouver: Faculty Association of the University of British Columbia, 1990).

${ }^{110}$ Bernard Berelson, “Library Unionization," The Library Quarterly 9, no. 4, (October 1939): 477. According to the obituary written by Lester Asheim for The Library Quarterly in October 1980, Berelson had done his doctoral work at the Graduate Library School (GLS) at the University of Chicago before going on to be both a "working librarian" as well as a well respected social scientist. He was the dean of the GLS from 1947 to 1951 and then pursued a career in public opinion research, writing a landmark textbook in 1950 entitled Reader in Public Opinion and Communication. Lester Asheim, "Bernard Berelson (19121979)," The Library Quarterly 50, no. 4 (October 1980): 407-09. See also Kathleen Weibel and Kathleen
} 
researcher Bernard Berelson summed up the issue in 1939: those opposed believed that unions were undignified for professional workers; those in favour believed that unionization was not "unrelated to their professional status, since the improvement of general social conditions is definitely reflected in library conditions."111 There is no evidence to suggest that over the next twenty years there were any major instances of attempts to unionize librarians in either Canada or the Unites States. Instead, thirty-four years after Berelson voiced his opinion, U of T library science professor Olga Bishop observed that librarians had devoted almost fifty years to raising the prestige and profile of their work through a model of professionalism that included training, hierarchical job rankings and a prescribed proportion of professional to clerical staff. ${ }^{112}$ In fact, by the 1960s when public employees including library staff started to unionize more frequently, there seemed to be a strengthening of interest in professionalization as librarians turned to professional organizations, such as the American Library Association (ALA) and the Institute of Professional Librarians of Ontario (IPLO), to play in collective bargaining by acting as "quasi unions." 113

Canadian historian Greg Linnell has suggested that the IPLO was a "singular expression of the professionalization of librarianship" in Canada. ${ }^{114}$ Using newsletter articles as well as histories of the IPLO written during the 1960s and 1970s by activist

M. Heim, eds., with assistance from Dianne J. Ellsworth, The Role of Women in Librarianship 1876-1976: The Entry, Advancement, and Struggle for Equalization in One Profession (Phoenix, Arizona: The Oryx Press, 1979).

${ }^{111}$ Ibid., 509.

${ }^{112}$ Olga B. Bishop, The Use of Professional Staff in Libraries: A Review 1923-1971, CLA Occasional Paper No. 81 (Ottawa: Canadian Library Association, 1973). This paper is a literature review of the development of professional librarianship in North America.

${ }^{113}$ See Katherine Todd, "Collective Bargaining”; and Greg Linnell, "The Institute of Professional Librarians of Ontario: On the History and Historiography of a Professional Association," 1, http://eprints.rclis.org/12214/, accessed July 1, 2012 (the online version is not paginated). The ALA was formed in 1876 to generally promote libraries and librarians and by the 1960s had a well-established tradition of non-involvement in employment issues except for producing salary surveys for librarians.

${ }^{114}$ Linnell, "The Institute of Professional Librarians of Ontario," 1. 
librarians, Linnell presents the early IPLO as a federation of librarians actively discussing the possibility of unionizing in order to improve their "working environment." ${ }^{\text {,15 }}$ The organizational mandate was to create a professional identity for librarians, thus in part providing an alternative to unionization; membership in a trade union would complicate the process of professionalization. ${ }^{116}$ To fulfil this mandate, one of the organization's key goals was to attain legal status as the professional regulatory body that would effectively allow it to function as a bargaining agent for its members. In doing so, the IPLO faced internal and external challenges. Members did not agree on the need for a professional identity, and leaders seemed to retreat from "direct action" after the mid-1960s, when a private bill to grant the IPLO regulatory powers was defeated. By the mid-1970s, new leadership attempted to reengage members in programs to promote professionalism but, despite these efforts, the IPLO disbanded in 1976 and Linnell suggests that this failure might have been due to the innate conservatism of some of its members.

In Creating Carleton, Neatby and McEown suggest one final factor that facilitated faculty unionization: CUASA leaders were able to convince the majority of their members to vote in favour of certification because they successfully positioned unionization as a "an option worth considering."117 Similarly, Mair and Canadian sociologist Sandra Rastin both argue that groups mobilize when they accept the legitimacy of a particular course of action. One of Mair's criteria for an episode of collective action is the presence of an ideological interpretation of a given situation. This interpretation must not only identify a particular issue (or issues) but also rationalize specific solutions. Rastin argues that the process of unionization, that is to say "how the

\footnotetext{
${ }^{115}$ Ibid., 8.

${ }^{116}$ Ibid.

${ }^{117}$ Neatby and McEown, Creating Carleton, 197.
} 
faculty members have been convinced to make the organizational transition" is critical to the success of certification campaigns. ${ }^{118}$ She analyzes the case of the joint effort of professors, professional librarians and archivists to unionize at Queen's University in 1995. She argues that Queen's University Faculty Association (QUFA) leaders paid attention to the "framing" of the issues during the union drive and thus were able to engage faculty ideologically through a three-step process: identifying a particular problem, assigning blame for the grievance, and then using "a carefully constructed message" to forge a link to a preferred solution. The QUFA executive successfully leveraged the concept of collegiality, a traditional academic ideal at Queen's, and convinced their colleagues that their current loss of decision-making power would only be rectified through collective bargaining.

This historiographical review reveals that generally the research on unionization at universities is fragmented. Scholars have used a variety of conceptual approaches to the collective action of university employees that tend to segregate professors, librarians and non-academic support staff into mutually exclusive categories. This segregation not only can preclude comparison but also reflects a fundamental disagreement amongst scholars as to the relative importance of agency and social structure in the process of historical change. Nonetheless, the research does suggest a number of important analytic strands to pursue. In particular, the emphasis that employees in each group placed on occupational status is meaningful in the context of collective action while gender also plays a critical role by shaping the nature and organizational value of work. Furthermore, together status and gender may play a significant role in legitimizing support for collective. These

\footnotetext{
${ }^{118}$ Sandra Rastin, "Organizing Tactics in a Faculty Unionization Drive at a Canadian University," Labor Studies Journal 25, no. 2 (Summer 2000): 99.
} 
concepts could provide the basis for exploring the factors that mobilized professors, librarians and support staff at Carleton to unionize.

\section{Explanatory Framework}

To explore the role that status and gender played in unionization at Carleton, it is necessary to use an interpretive approach that can adequately account for differing occupational identities, the relationship between these identities and institutional standing and the process by which unionization was transformed from an "unthinkable" to an acceptable option for individual professors, librarians and support staff. In essence, the analytic framework must allow for the influences of both social structure and agency. I think that E. P. Thompson's notion of "moral economy" provides such an overarching framework for this comparative study of unionization. In addition, Axel Honneth's model of moral disrespect, British sociologist Rosemary Crompton's definition of status and R.W. Connell's concept of gender supplement Thompson's approach in useful ways as do Jenny Kitzenger and Robert Entmann's explanations of "framing," that help to address more fully the process by which consensus for unionization was achieved.

In developing his concept of the "moral economy," Thompson advised fellow historians to avoid "crass economic reductionism" when analyzing collective action; group behaviour is complex and "modified by custom, culture and reason" not just monetary or financial needs. ${ }^{119}$ Out of a study of $17^{\text {th }}$ century food riots in England, he proposed that social disturbances should not always be categorized as simply chaotic reactions to physical or environmental stimuli. Instead, group action can be explained in terms of three key dimensions. First, that each episode of conflict or resistance is rooted

${ }^{119}$ E.P. Thompson, "The Moral Economy of the English Crowd in the Eighteenth Century," Past and Present no. 50, (February 1971): 76-79. 
in a "legitimating notion" that justifies group action; in particular, people will act together to defend those "traditional rights or customs" that they perceive to be threatened or violated. Second, those who act believe that they have the support of the majority of their community; this consensus can overcome feelings of "fear or deference" to authority. Finally, the "authorities" will sometimes endorse the conflict because, to some extent, they too believe in the rights or customs being defended. On the whole, collective action can be "disciplined and with clear objectives" and based upon a set of core values and beliefs that is shared by many. ${ }^{120}$ This idea of a "moral economy" can be applied to a variety of forms of social action, including unionization.

Drawing on the work of a number of scholars including Thompson and American sociologist Barrington Moore, German philosopher Axel Honneth agrees that there can be a "moral logic" to certain types of social action but defines the underlying motivations more broadly than a defence of rights or traditions. Instead, individuals and groups can be motivated by experiences of what he calls "moral disrespect." ${ }^{121}$ Honneth suggests that societies are organized around "implicit rules of mutual recognition" based on personal identity. These rules encourage individuals to expect certain forms of respect, recognition, or treatment based on their identities. If these rules are contradicted, individuals can feel hurt or injured because their expectations have not been met: they believe they have not been recognized appropriately and have been unjustly treated. When personal experiences are understood to be generally representative of those of a specific group, then "collective demands for expanded relations of recognition" can be legitimately made

\footnotetext{
${ }^{120}$ Ibid., 78-79.

${ }^{121}$ Axel Honneth, The Struggle for Recognition. The Moral Grammar of Social Conflicts, tran. Joel Anderson, (Cambridge, Massachusetts: The MIT Press, 1996), 161.
} 
and related to both traditional and new forms of identity. ${ }^{122}$ Honneth's repurposing of Thompson's definition of "legitimating notion" not only expands the range of possible motives but also makes a more explicit connection between conflict and identity, as well as conflict and social recognition or respect.

Rosemary Crompton's definition of status provides a basis for conceptualizing identity and the moral logic of conflict in the context of work. In her 1987 article entitled “Gender, Status and Professionalism," she develops a framework for understanding the placing of women within organizations and occupational hierarchies and suggests that both identity and recognition are critical elements of social status and thus workplace relations because status contributes directly to the shape of occupational structures. ${ }^{123}$ In turn, these structures represent institutional divisions of labour and determine the differences in monetary and non-monetary rewards amongst employee groups. Based on the work of German sociologist Max Weber, she suggests that the status of an occupational group can be defined in terms of two components: standing and identity. ${ }^{124}$ Standing is the respect or prestige received by a group from the organization to which it belongs and this recognition is based on group identity. Identity is the result of both a sense of affiliation or belonging that members share and the common patterns of behaviour that reinforce group membership, i.e., "lifestyle" or work style. Affiliation is achieved when individuals meet certain eligibility criteria that can include qualities such as gender, race, ethnicity, education, occupation and religion. Ultimately, a group's

\footnotetext{
${ }^{122}$ Ibid., 162.

${ }^{123}$ Rosemary Crompton, "Gender Status and Professionalism,” Sociology 21, no. 3 (August 1987): 413-28.

${ }^{124}$ The basic model can also apply to individual employees. In addition, Weber's original theory explained status within a society; Crompton argues that this theory can also be applied more narrowly to organizations.
} 
position is a combination of standing and identity, and reflects its organizational "worth," i.e., its status. Status is thus a determinant of the quality of life group members enjoy. This "life fate" can be measured by benchmarks such as income, benefits and conditions of work. Crudely, employee groups with a higher ranking or status have a better quality of work life.

Crompton emphasizes the importance of eligibility requirements to group identity. The significance of specific qualities varies between groups and can clearly delineate the boundaries between occupations, thus having a direct impact on the division of labour and status within organizations. Only those employees with certain qualifications will be hired for specific positions and have the opportunity to attain a relatively high organizational status and the monetary and non-monetary benefits that come with these jobs. The weighting of eligibility criteria can vary between groups during a specific historical period and can also change for individual groups over time. For example, in the 1960s and 70s, Canadian women began to argue that sex (i.e., biology) should no longer be used to exclude them from certain occupations or justify lower rates of pay than those earned by men. Crompton is particularly interested in the role that gender plays in determining status. She suggests that qualifications can be culturally "sex-typed" (i.e., feminized or masculinized). If given skills or traits are identified as female, then the occupations for which they are required will have a lower status and in turn produce both lower monetary rewards (e.g., income) and non-monetary rewards. Conversely, "male" qualities will receive higher rewards. Overall, differences in eligibility criteria and therefore identity may reflect attempts to either maintain or improve both occupational recognition and ranking efforts that could lead to conflict in the workplace. 
It is important at this point to explain the concept of feminization that I use in this thesis, given that this term appears frequently in the literature on librarianship and clerical work. ${ }^{125}$ Feminization can be defined as a complex process of gender segregation that is contingent on time and place. When feminization takes place in the labour market, scholars generally argue that jobs that traditionally have been economically, biologically and/or ideologically defined or sex-typed as "male" become "numerically dominated by women and discursively marked as 'women's work'."126 Typically, researchers argue that this transformation has specific and predictable consequences. ${ }^{127}$ Employees doing "women's" jobs are primarily if not exclusively female, receive low wages relative to men doing similar or equivalent work and have fewer opportunities for a career, i.e., upward job mobility. Employers (and indeed society in general) can and do justify these outcomes in terms of the relatively low skill and minimal training as well as experience supposedly required to do such work and the expectation that women's participation in

${ }^{125}$ The history of the gendered nature of American librarianship has been studied extensively. One of the most oft-cited studies is Garrison's Apostles of Culture, which typically is the primary historical source for the feminization of librarianship in North America as published Canadian historical literature on this topic is scarce. However, both "Professionalization, Gender and Librarianship in Ontario, 1920-75," by Canadian historian Lorne Bruce and Nina Milner's master's thesis, "Lady Librarian": The Feminization of Librarianship in Canada, 1880-1920," provide historical accounts of this process in Canada. Likewise, in Women in the Administrative Revolution Graham Lowe uses this concept to discuss the changes in clerical work in Canada in the late $19^{\text {th }}$ and early $20^{\text {th }}$ century. Lorne Bruce, "Professionalization, Gender and Librarianship in Ontario, 1920-75," Library and Information History 28 no. 2 (2012): 117-34 and Nina Milner, "Lady Librarian": The Feminization of Librarianship in Canada, 1880-1920," (master's thesis, University of Ottawa, 1992. See also Monica Boyd, "Feminizing Paid Work," Current Sociology 45, no. 2 (1997): 49-73; Kim England and Kate Boyer, "Women's Work: The Feminization and Shifting Meanings of Clerical Work," Journal of Social History 43, no. 2 (2009): 307-40; Samuel Ross Cohn, "Clerical Labour Intensity and the Feminization of Clerical Labor in Great Britain, 1857-1937," Social Forces 63, no. 4 (1985): 1060-68.

${ }^{126}$ England and Boyer, "Women's Work," 307.

${ }^{127}$ Typically when this term is used, the definition refers to the predominance of women in a particular occupational category. Scholars often do not, however, discuss in any detail what Pat Armstrong and Hugh Armstrong refer to as the biological, ideological and materialistic explanations for this phenomenon or the fact that the work in question has traditionally been masculinized, i.e., been defined as men's work and done by men but then has undergone a process by which is becomes identified as women's work. Pat Armstrong and Hugh Armstrong, The Double Ghetto. Canadian Women and Their Segregated Work (Toronto: McClelland and Stewart, 1978). 
the labour market will be uneven, whether or not this reasoning is accurate. Effectively, feminization creates female occupational ghettos by segmenting the workforce and thus limits the participation of women in any given labour market—and these conditions persist over time. As Pat Armstrong and Hugh Armstrong pointed out in 1978, "In Canada today, there is men's work and women's work. Women are segregated into the domestic unit where they perform the household chores. Within the industrial unit, women are concentrated in a limited number of occupations, i.e., in sex-typed jobs." ${ }^{2128}$ Although women had participated in the Canadian labour market during the $20^{\text {th }}$ century at increasingly higher rates, their paid work continued to be segregated and cheap because fundamentally there had been no change "in the division of labour by sex or in the nature of women's work." ${ }^{129}$

Returning to status, it can be argued that status, like class, is the product of interaction and negotiation between individuals and groups within organizations and a form of social structure or what Australian sociologist R.W. Connell calls "enduring" patterns of social behaviour. ${ }^{130}$ Connell is considered an expert on gender studies, and particularly the study of what she has termed "hegemonic masculinity." "131 She argues that social structures have inherent contradictions or "crisis tendencies" which can lead to social struggles and change. Certainly shifts in occupational identities—which could be on-going and inevitable - might provoke crisis or eventually conflict and thus organizational change. Although Crompton argues for the relative importance of gender

\footnotetext{
${ }^{128}$ Ibid., 14. Hugh Armstrong had graduated from Carleton University and went on to be a professor of social work at the university until his retirement in 2013.

${ }^{129}$ Ibid.

${ }^{130}$ R.W. Connell, Gender. Short Introduction (Cambridge: Polity, 2002), 9.

${ }^{131}$ See for example, R.W. Connell, Masculinities, $2^{\text {nd }}$ ed., (Berkeley, Los Angeles: University of California Press, 2005).
} 
in shaping occupational structures, she does not explicitly define this concept. On this issue I found Connell's work on gender useful as she provides a good summary of the current understanding and definition of gender. She proposes a robust definition that incorporates both the physical basis for gender as well as its role in social processes. Connell rejects the idea that gender is simply a product of the cultural differences between men and women based on biology. She argues that this explanation is inadequate for several reasons. It effectively creates dichotomies that are refuted by empirical evidence; focuses attention on differences between men and women thus rendering invisible significant similarities in their behaviour but also dissimilarities within groups of men and within of women; and privileges personal characteristics over "large-scale social processes. ${ }^{\not 132}$ Instead, she proposes that gender be considered as an important social structure and in particular, "the structure of social relations that centres on the reproductive arena, and the set of practices (governed by this structure) that bring reproductive distinctions between bodies into social processes. ${ }^{\text {133 }}$ One of the critical aspects of this approach is that it encourages the exploration of a variety of forms of masculinity and femininity, practiced by both men and women. ${ }^{134}$

A final interpretative element comes from the literature on framing. Employee groups and Carleton University administrators both ran public relations campaigns to gain consensus on the issue of unionization. In particular, both CUASA and CUSAA

132 Ibid., 8-9.

${ }^{133}$ Ibid., 9.

${ }^{134}$ For an application of Connell's concept, see for example, Joan Acker, "Hierarchies, Jobs, Bodies: A Theory of Gendered Organizations," Gender \& Society 4, no. 2 (1990): 153. Acker defines hegemonic masculinity as "a certain kind of male heterosexual sexuality [that] plays an important part in legitimating organizational power ... formed around dominance over women and in opposition to other masculinities." Although Acker's work on gendered hierarchies is foundational. I used Ronnie Steinberg's work on job evaluation systems and organizational hierarchies instead. Steinberg also uses the concept of gender but her work focuses on the use of the Hay system of job evaluations that was instrumental in the placement of support staff within the occupational hierarchy at Carleton (see Chapter 4 of this thesis). 
began to produce newsletters in the period leading to certification while the university's Public Relations and Information Services distributed a publication at the same time. As has been done in other studies, these archival and primary documents will be analyzed using the concept of framing to understand how the idea of certification was presented and legitimized by association leaders or counteracted by university administrators. ${ }^{135}$

Coming from the work of sociologist Ernest Goffman, ${ }^{136}$ the notion of a frame refers to a representation (or account) of reality in which particular aspects of a given reality are selected or omitted and made salient (meaningful) "in a communicating text in such a way as to promote a particular problem definition, causal interpretation, moral evaluation and/or treatment recommendation. ${ }^{, 137}$ As both British scholar Jenny Kitzinger and American professor Robert Entman explain, the following three aspects of a text should be analyzed. The production or where frames come from: individual communicators choose particular frames that in turn are shaped by their own belief systems and the broader social and cultural context in which they live. The content: embedded frames are visible through the words (including keywords, figures of speech, groupings of facts, narrative structure), images and sounds (when applicable) that are used to present an issue. Finally, the reception of the frames: like the communicator, the receiver's reaction is influenced by frames that are rooted in his/her value system and social reality. ${ }^{138}$ In addition, they suggest that a thorough frame analysis does not focus

\footnotetext{
${ }^{135}$ For example Rastin, "Organizing Tactics."

${ }^{136}$ Robert M. Entman, "Framing: Toward Clarification of a Fractured Paradigm," Journal of Communication 43, no. 4 (December 1993): 52.

${ }^{137}$ Ibid.

${ }^{138}$ Jenny Kitzinger, "Framing and Frame Analysis," in Media Studies. Key Issues and Debates, ed. Eoin Devereux (Los Angeles, London, New Dehli, Singapore: Sage Publications, 2007), 134-61; Entman, "Framing: Toward Clarification of a Fractured Paradigm." Media influences are areas of interest for both Kitzinger and Entmann (FN 135, Chapter 1).
} 
on one or two components to the exclusion of the third. ${ }^{139}$ Entman argues that, in fact, salience is very much an interactive process that is "the product of the interaction of texts and receivers, [and] the presence of frames in the text, as detected by researchers, does not guarantee their influence in audience thinking."

Returning to Thompson's concept of the moral economy, it can now be argued that although discontent may be triggered by an historical combination of social, economic or political factors, employees may engage in collective protest or struggles as a result of a particular experience of employer disrespect. Based on their identity as either employees or more specifically members of a specific occupational group in a particular organizational context, individuals expect to be treated properly according to the nature of their work. If "the management" does not respond appropriately, employees can perceive a fundamental contradiction between this response and their expectations and their "rights" and thus effectively experience a threat to their overall status. These rights may be based on a traditional understanding of their work and qualifications but may also stem from changing perceptions of their work based on the shifting importance of particular qualifications or eligibility criteria. For any group of employees to take collective action, its members must reach consensus on the legitimacy of their rights as well as the appropriateness of a given response to employer disrespect. In essence, the framing of any changes in labour relations must be compelling enough to gain the support of the majority and overcome any internal group opposition. The frame must also be persuasive enough to mitigate against fear of reprisal.

\footnotetext{
${ }^{139}$ Kitzinger, "Framing and Frame Analysis," 138. Kitzinger argues that production has been neglected in favour of content and reception analysis.

${ }^{140}$ Entmann, "Framing: Toward Clarification," 53.
} 
Finally, Thompson reminds us that it is also important to attend to all forms of resistance to collective action, that within a given socioeconomic group but also any conflict that arises between groups and, specifically, between protesters and those in positions of authority. As he suggests, there can be consensus within communities on “traditional rights or customs." As a result of these shared values, individual authorities may or may not make concerted efforts to obstruct collective action. In the case of labour action, while collective action can be met with employer hostility and resistance, in some cases "the management" may react with minimal or no overt antagonism because managers may share to some extent the core values of their employees. The lack of institutional response, if not rooted entirely in agreement, at least appears to somewhat endorse the action being taken.

\section{Research Method: Oral History}

Interviews with administrative, clerical and technical employees as well as librarians and professors represent the principal source of evidence for this thesis. ${ }^{141}$ Memories in the form of personal narratives have been collected in order to recover and record the meaning of union formation for those who participated in this process at Carleton University - particularly the "voices" which have not yet been heard. I conducted twenty-seven interviews (see Appendix I for list of interviewees) and was in a unique position to identify participants, given that I have worked full-time at Carleton University for eleven years and have held a CUPE 2424 position in the library for the

\footnotetext{
${ }^{141}$ I am using the term oral history to refer generally to the research method of gathering memories through in-depth interviewing as discussed in Mairtin Mac Con Iomaire's overview "Hidden Voices from the Culinary Past: Oral History as a Tool for Culinary Historians," Richard Hosking, ed., Food and Language: Proceedings of the Oxford Symposium of Food and Cookery (Totnes: Prospect Books, 2010): 217-226; and Mac Con Iomaire's longer conference paper "Hidden Voices from the Culinary Past: Oral History as a Tool for Culinary Historians”, ttp://arrow.dit.ie/tfschcafcon/5/, accessed November 26, 2013.
} 
past four years (CUPE 2424 succeeded the Carleton University Support Staff Association [CUSSA] in 1980). I started the research process with a preliminary list of four interviewees: Sylvia Gruda, one of the leaders of the CUSSA certification drive; Blair Neatby and Don McEown, the co-authors of Creating Carleton; and former Carleton president (1996-2005) Richard Van Loon. I had met Gruda and Van Loon through union or job-related activities, and had consulted Neatby and McEown for previous research assignments.

These connections were strategically important because each person was willing to suggest the names of other individuals to approach, particularly Pat Finn, who had not only been instrumental in the CUSSA drive but also been the executive director of the Carleton University Academic Staff Association (CUASA) for over thirty years. In an initial meeting prior to beginning the formal research process, Finn agreed to participate as well as supply the contact information for retired CUASA and CUSSA members who she knew had been working at the university during unionization. The names of additional participants came up during subsequent conversations with professors in the Carleton history department, ${ }^{142}$ the oral history interviews or the reading of primary documents. These participants include retired employees as well as two spouses and two Carleton alumnae as well as Ken Clavette, an expert on Ottawa labour history and my aunt Elaine Empey who had lived in Ottawa during the 1940s. The two alumnae are Phyllis McRae, who was hired as the membership coordinator of the CUSSA campaign, and Debra Mair, whose master's thesis on the unionization of faculty in 1977 has already been discussed.

\footnotetext{
${ }^{142}$ In particular a conversation with retired Carleton history professor John Taylor who is an expert on the history of the city of Ottawa.
} 
The development of my semi-structured interviews was informed by best practices for collecting data through oral history interviews. ${ }^{143}$ The list of six pre-determined questions (see Appendix II) was designed to promote the relatively rapid yielding of useful material during the interviews that would lead to an understanding of the process of union formation. These were not "life story" interviews but the questions were openended enough to allow the participants to share their understanding of unionization as well as its meaningfulness to them. In addition, it allowed the interviewees to raise unforeseen topics and prompted me to ask questions that I had not thought of ahead of time. Even though the participants did not come overtly with what historian Joy Parr has labelled a "legacy of pain," 144 the process confirmed that interviewees can become uncomfortable when discussing seemingly innocuous events or topics. ${ }^{145}$

The interviews were conducted over the next thirteen months (see Appendices III, IV and V). ${ }^{146}$ All interviewees were initially contacted either by phone or email. Twentythree initial interviews were conducted with participants living in Eastern Ontario, with three additional in-person sessions being done to follow-up on new topics introduced in the first interviews. Three follow-up email exchanges were also conducted with some of these participants to verify facts. All of the interviews were done face-to-face, except one that was conducted by telephone and one shorter interview was done by email (contact with Geoffrey Briggs was strictly through email given that he resides in Australia). Twenty-one sessions were conducted one-to-one and four with a pair of participants: two

\footnotetext{
${ }^{143}$ For an overview, see Valerie Raleigh Yow, Recording Oral History. A Guide for the Humanities and Social Sciences, $2^{\text {nd }}$ ed. (London, New York: Rowman \& Littlefield Publishers Inc.).

${ }^{144}$ Joy Parr, “'Don't Speak For Me': Practicing Oral History amidst the Legacies of Conflict," Journal of the CHA 2010/ Revue De La SHC New Series 21, 1 (2010): 1-11.

${ }_{145}$ In one interview, the participant indicated that recalling memories of childhood felt difficult.

${ }^{146}$ Ethics clearance was renewed in May 2011. Appendices III and IV are the generic letter of information and informed consent statement received or signed by each participant.
} 
married couples and two sets of work colleagues. Participants were encouraged to suggest an interview location that was suitable for them and for those done in person, we met either at their residences, on campus or at the interviewee's workplace. All were video recorded except the telephone session, which was tape recorded. ${ }^{147}$ Handwritten notes were taken during all the sessions and all but two interviews were transcribed, either by me or by a Carleton University student hired to do this work and these transcriptions are unedited. I considered using a qualitative software program to code the transcripts but decided against this method of analysis because I had introduced it too early in the research process, before I had a clear enough idea about the concepts I would be using and thus the themes I would highlight. I loosely followed a grounded theory approach, ${ }^{148}$ developing my explanatory framework based upon the patterns and themes that emerged as I read the transcripts or reviewed the videotapes.

The logistics of gathering the personal narratives seem relatively straightforward and since World War II scholars have revived the use of oral histories and embraced memories as a source of primary evidence. ${ }^{149}$ Inevitably there has been scholarly debate

${ }^{147}$ As requested by the participants, in two of the videos the individuals do not appear on camera. However, the audio quality from the video camera is better than that from the tape recorder and thus they agreed to let me use the camera.

${ }^{148}$ Anselm L. Strauss and Juliet Corbin, eds., Basics of Qualitative Research: Techniques and procedures for Developing Grounded Theory, $2^{\text {nd }}$ ed. (Thousand Oaks: Sage Publications, 1998).

${ }^{149}$ See for example Yow, Recording Oral History, Paul Thompson, The Voice of the Past. Oral History, $3^{\text {rd }}$ ed. (Oxford, New York: Oxford University Press, 2009); Alessandro Portelli, "What Makes Oral History Different," reprinted from The Death of Luigi Trastulli, and Other Stories: Form and Meaning in Oral History (Albany, N.Y.: State University of New York Press, 1991 in The Oral History Reader, $2^{\text {nd }}$ ed., eds. Robert Perks and Alistair Thomson (London, New York: Routledge, 1998), 32-42; and David K. Dunaway and Willa K. Baum, eds., Oral History. An Interdisciplinary Anthology, 2nd ed. (Walnut Creek, London, New Delhi: Altamira Press, 1996). See also the special issue of the Journal of Canadian Studies 43, no. 1 (Winter 2009) entitled "Sharing Authority: Community-University Collaboration in Oral History, Digital Storytelling, and Engaged Scholarship"; Joan Sangster, "Telling Our Stories: Feminist Debates and the Use of Oral History: A Rewarding Alliance," Oral History/Forum d'Histoire Orale Special Issue:

Working Lives: Special Issue on Oral History and Working-Class History 33 (2013): 1-15; Joan Sangster, "Politics and Praxis in Canadian Working-Class History," in Oral History Off the Record, eds. Anna Scheftl and Stacey Zembrzycki (New York: Palgrave, 2013), 59-76. 
as to the nature of this "data" - is it factual information about events or is it subjective and related to the meaning or significance of events? - as well as how to collect and analyze it. In particular, historians have been divided on the relative merits of memories as "more history" and "no history." 150 Some scholars assume that personal narratives can be read using practices similar to those for documentary analysis to provide new insights and perspectives into the experiences of individuals or groups whose stories have not previously been told. Others treat reminiscences as direct windows into the past that require little or no mediation. In either case, however, it is assumed that ultimately the historian will use his or her expertise objectively to design the interview, analyze the collected material and author the history. American historian Michael Frisch argues that applying the oral history technique is inherently complicated. ${ }^{151}$ In his anthology $A$ Shared Authority. Essays on the Craft and Meaning of Oral and Public History, he contends that this research approach is not a variation on the traditional historical method based on the expert interpretation of documentary evidence. Instead, while "historical memory patterns are cultural documents," the process of doing oral history should be considered one of "shared authority" or joint authorship and is distinct from other methods in that it recognizes that remembering is psychologically complex and inherently subjective and, therefore, that oral history interviews are "inter-subjective" and collaborative.

According to Valerie Raleigh Yow, psychological research has shown that the brain produces memories by using fragments of recorded experience to reconstruct a

\footnotetext{
${ }^{150}$ Michael Frisch, A Shared Authority. Essays on the Craft and Meaning of Oral and Public History, (Albany: State University of New York Press, 1990), 9.

151 Ibid.
} 
variety of accounts of past events. ${ }^{152}$ This process begins when the brain registers information about events that are important to us, both those that we actually experience and those that we observe. Over time we will forget details but our long-term memories have proven to be quite stable and reliable - we are able to tell a story consistently on many different occasions even forty or fifty years after something has happened. ${ }^{153}$ This is why, to paraphrase Ron Grele, the personal narratives of people over thirty can be trusted. ${ }^{154}$ Usually we remember how we felt about a person or past event. However, we may recall the details of a single, dramatic event better than those of everyday occurrences or habits while trauma can lead to the suppression of events. Some historians argue that the inability to accurately recall details is a weakness of the oral history method; others, such as Frisch and Alessandro Portelli, suggest that this very subjectivity or bias is a strength. Oral histories are credible because they are "psychologically true" and the silences, omissions, distortions, and mistakes can reveal more about the importance of a particular event to an individual than his or her inability to remember dates, names, places or a sequence of events. ${ }^{155}$

In the context of oral history, remembering is also "inter-subjective" and as Parr has suggested, even a "thick barrier of [academic] safeguards" such as well-designed interview questions cannot strip the interaction of its interpersonal dynamic. ${ }^{156}$

${ }^{152}$ Raleigh Yow, Recording Oral History, 36.

${ }^{153}$ Alice Hoffman emphasizes the importance of both reliability and validity in interviews which she defines as follows: "Reliability is the consistency with which an individual will tell the same story about the same events on a number of different occasions. Validity refers to the degree of conformity between the reports of the event and the event itself as recorded by other primary material." Alice Hoffman, "Reliability and Validity in Oral History," first appeared in Today's Speak 22 (Winter 1974): 23-27, reprinted in Oral History, eds. Dunaway and Baum, 87-93.

${ }^{154}$ Ron Grele, "Can Anyone over Thirty be Trusted: A Friendly Critique of Oral History," The Oral History Review 6 (1978): 36-44.

${ }_{155}$ Ibid., 37.

${ }^{156}$ Parr, "Don’t Speak for Me." 
Interviewees are being asked to share their recollections in a highly social situation to which the historian and interviewee(s) take their own statuses ${ }^{157}$ and perspectives. These situations pose inherent challenges to collecting "gold" rather than "trash" because both parties may introduce biases. Interviewees may consciously or unknowingly edit their responses for a number of reasons unrelated to the psycho-physiological process of remembering. For example, sometimes as a result of "contemporary pressures and sensitivities" participants will remember that which is culturally significant or details based on a personal need to conflate or deflate their involvement in an event. ${ }^{158}$ Interviewees can also modify their answers in order to make a certain impression, either on the interviewer or anyone else present during the interview as in the case of interactions between a historian and two participants such as spouses or co-workers. ${ }^{159}$ Interviewers may also be biased and in the literature there are some references to the risk of the historian making "hasty judgements" about the information he/she is receiving. ${ }^{160}$

Either way, rapport or trust between historian and participant(s) needs to be established to ensure that the process is mutually satisfactory. Historians have discussed at some length the issue of power relations during interviews and attention has been focused on the imbalances or "social distances" that can jeopardize rapport if the interviewee changes or manipulates his/her memories as a result of feeling intimidated by the expertise of the historian. ${ }^{161}$ In the case of my research on unionization at Carleton,

${ }^{157}$ Status is used here in the sense defined by Crompton; it includes both the social bestowed standing as well as the identity based on belonging to a group with a particular lifestyle.

${ }^{158}$ See for example, William Cutler III, "Accuracy in Oral History Interviewing," first printed in Historical Methods Newsletter 3 (June 1970): 1-7, reprinted in Oral History, eds. Dunaway and Baum, 99106; Frisch, Shared Authority, 12.

${ }^{159}$ H.R. Boeije, "And Then There Were Three: Self-Presentational Styles and the Presence of the Partner as a Third Person in the Interview," Field Methods 16, no. 1 (February 2004): 4.

${ }^{160}$ Cutler, "Accuracy in Oral History Interviewing," in Oral History, eds. Dunaway and Baum, 102.

${ }^{161}$ Raleigh Yow, Recording Oral History, 157-87. 
some participants initially seemed uncomfortable or uneasy with the process and there were also interviews in which the risk was reversed. In several instances, either with well-established scholars or Don McEown who had substantive knowledge of the university, I felt initially intimidated and hesitant to pursue a particular line of inquiry. In addition, I did four interviews that each included two participants: spouses and coworkers and was aware that the pre-existing relationships between these individuals could influence the interpersonal dynamic in the interview ${ }^{162}$.

Frisch argues that one way to minimize such risks is to approach the "oral history" interaction as a collaborative relationship. The interview is not a one-way flow of information wherein the role of the interviewer is to ask questions and the role of the interviewee is to answer. Nor is the interviewee solely responsible for self-disclosure. Instead, the participants are actively engaged in a dialogue; they are communicating with each other, sharing information and interpreting memories together to produce an individual narrative. In addition, sometimes rapport can be built if the interviewer also has first-hand knowledge or expertise in the area being researched. As Irish historian Martin Mac Con Impaired has pointed out, this insider status can establish the interviewer's credentials and lead to "creative interviewing" in which "mutual respect and understanding ... [produce] ... very detailed conversations and [secure] fresh and significant data." 163

I found this concept of shared authority useful throughout the interviewing process. As I met with more participants, I gained confidence in my line of inquiry and my

\footnotetext{
${ }^{162}$ In the interview with librarians Susan Jackson and Frances Montgomery, Jackson has been the head of the library's Maps, Data and Government Information Centre (MADGIC) for over 30 years and Montgomery has reported to her as the government documents librarian for a significant amount of the time.

${ }^{163}$ Mac Con Iomaire, "Hidden Voices (conference paper)," 8.
} 
knowledge of the process. This confidence helped to overcome feelings of insecurity and I was either able to collaborate more fully or encourage participants to do so.

Consequently, many of the participants often seemed surprised at how much of their past experiences they were able to recall and even occasionally shared personal information that was of a sensitive nature that was not necessarily obviously linked to the topic of unionization but nonetheless was important to their identity and experiences. As a former bereavement facilitator, I recognized the importance of these details - they represent opportunities to build trust through mutual self-disclosure - and where appropriate I selectively shared my own similar experiences. As both a CUPE 2424 member and a library employee, I think that my interviews with support staff members and librarians were more "creative" than those with faculty or Carleton historians Neatby and McEown in that I had some credibility based upon my work experience and could probe issues in a more informed manner. The collaborative aspect of the interviews also seemed to reassure participants who might also be worried about the "big gaps in their memories" as I explained that they were not responsible for providing all the factual information; as a collaborator, part of my job was to confirm these details. ${ }^{164}$

Within this shared authority approach, Frisch suggests that the oral history interview is an opportunity to work with people as they make sense of their lives and experiences. The benefits of this process are twofold: memories represent "less about events than about meaning" ${ }^{165}$; and the process of recall and synthesis that happens as an individual recollects events and experiences reveals insights into the creation of memory. Practically, Frisch recommends that the analysis of personal narratives focus generally on

\footnotetext{
${ }^{164}$ For example, Phyllis McRae, former CUSSA membership coordinator, in oral history interview with the author, April 16, 2011.

${ }^{165}$ Portelli, "What Makes Oral History Different?," 50.
} 
three basic questions: "What sort of person is speaking? What sort of thing is he or she talking about? What sort of statements about it are being made?"166 In particular, he suggests that historians be attentive to the specific role of the narrator in a given event i.e., his or her direct or indirect involvement. In addition, the "historicality" of each narrative must be understood, which Frisch defines as the difference between an individual providing historical evidence or making an historical statement. To understand historicality, he argues that it is necessary to determine if an individual is creating or reducing the distance between him/herself and an experience from the past. When a participant shares detailed personal anecdotes about something that he or she actually experienced, Frisch considers that distance is minimal and this information is historical evidence. When someone offers a more abstract reflection on an observed event or general socioeconomic condition from the past, then distance is greater and this information is an historical statement.

In his experience as an oral historian, Frisch has found that this "spectrum of particularity and generality" is critical. ${ }^{167}$ The patterns of detailed recollection and abstract generalization can lead to an understanding of the meaningfulness of a given past experience for an individual as well as the society in which he or she lives. In addition, these patterns reflect "the process by which the past is received, digested and actively related to the present." ${ }^{\prime 168}$ While the purpose of my research is not to explicitly explore the nature of memory production, I have attempted to use Frisch's concept of "historicality" when interpreting the personal narratives collected during the interviews I conducted.

\footnotetext{
${ }^{166}$ Frisch, Shared Authority, 10.

${ }^{167}$ Ibid, 11.

168 Ibid., 61.
} 
Although it is important to recognize that memory can be selective, such accounts bring life to the experiences of individuals whose stories might not be told otherwise (e.g., they occupied positions or played roles at the time a particular event that did not lead to paper documents) and can corroborate or, conversely, challenge the paper sources which might tell the story from the perspectives of other individuals involved an event.

Likewise, paper sources can confirm, clarify or correct the details and facts that come out during an oral history. These sources, however, must be approached with the understanding that documents are often the "official" recording of an event and may, in fact, omit details or aspects of a story that would not have been considered appropriate or important to record at the time.

\section{Sources and Outline}

This thesis is also based on a variety of other documentary evidence than the collected personal narratives. Archival documents originate mainly from two sources: the Carleton University Corporate Archives and the Carleton University Library Archives. The Carleton University Corporate Archives are responsible for the preservation of information of enduring historical, legal, fiscal, administrative and evidentiary value to the university. The documents that have been consulted include minutes and correspondence from the offices of the senior administration (i.e., the president, various vice-presidents and the secretary to the board), letters, memos, faculty and staff newsletters, the university's newsletter, employee handbooks and the Ontario Labour Relations Board (OLRB) decision with regard to the certification of CUASA. Similarly photocopies or scans of documents were obtained from the Carleton University Library Archives including library newsletters, memos, and pages from issues of the Carleton 
University student newspaper published in the 1950s, 1960s and 1970s (the title of the student newspaper was The Carleton until 1969 when it was changed to The Charlatan). These papers are located in the fonds that are part of the library's historical collection of corporate ephemera rather than the collection housed in the corporate archives. Copies of other original documents were obtained from participants such as Pat Finn, Frances Montgomery and Sylvia Gruda. These included staff newsletters, the university's 1976 status of women report written by Finn, a sociology essay written by Gruda on the CUSSA certification while she was a Carleton student and Phyllis McRae's final field placement report on the certification campaign prepared for the union executive. A copy of the OLRB decision on the certification of the support staff union was requested and obtained from the OLRB library via email. Finally, copies were made of original university financial statements that are filed in the Office of the Board of Governors. Additional evidence include articles written during the period and published in journals or professional publications such as the Library Quarterly (the journal for the American Library Association), the Canadian Library Journal (produced by the CLA from 1969 to 1992), the CAUT Bulletin (the official print publication of the (Canadian Association of University Teachers) and likewise the IPLO Quarterly (produced by the Institute of Professional Librarians of Ontario). They represent the contemporary debates on professionalization and unionization by those directly involved in these processes. In addition, Debra Mair's 1977 thesis, which I have also used earlier as secondary evidence, includes quotes from anonymous faculty collected during an interview process.

Four chapters now follow this introduction. Chapters 1, 2 and 3 chart the experiences of each of the three occupational groups and have the same basic three-part 
structure for analyzing the unionization of these employees: early identity formation that provided the basis for later collective action; the beginnings of discontent as well as the chronology of key events that triggered mobilization and punctuated the certification drives; and an analysis of the sources of both support for and resistance to unionization amongst group members and the moral logic that was used to gain a majority vote in favour of certifying. The last section in each chapter includes the conclusion and an epilogue.

The first section of each chapter provides the historical context for the formation of occupational identities. For faculty members, this background includes an in-depth review of the university governance structure. While some of this information is included in other sources such as Neatby and McEown's Creating Carleton, it is critical to revisit because the university's governance structure ordered relationships and thus played a significant role in the early discontent of professors, which in turn created tensions during the certification drive. Similarly, the chapter on librarians begins with a history of the development of librarianship in Canada and the library at Carleton. This information is important because there is no published account of the feminization of this occupation in Canada, a process that was integral to mobilizing librarians at Carleton to unionize, and the history of Carleton's library has really not been told. Likewise, in Chapter 4, I have tried to provide a history of support staff at Carleton, primarily because this information contextualizes later tensions but also because the history of this employee group has not been recorded elsewhere. The latter section of each chapter offers a detailed analysis of the faculty and staff newsletters to explore both the messaging that appeared "in" the frames (i.e., in print) and the issues which appeared "outside" the frame as identified 
through personal narratives. These newsletters were distributed to all faculty and staff and were accessible to university administrators. They demonstrate well the strategic use of framing, which, in turn, reveals the degree to which status and gender were critical to legitimizing unionization on campus.

I have deliberately chosen to treat each group separately rather than combining their stories into thematic chapters. While one of the key goals of this thesis is to highlight the similarities between groups, I also want to ensure that the stories of each group can stand alone and are recognized for their singularity. Moreover, I am concerned that if the experiences of librarians and support staff employees are combined with those of faculty, once again their histories would be hidden behind that of the dominant institutional group. By devoting a chapter to each group, I think that the comparisons adequately reveal important similarities and differences with the benefit of attention to the distinctiveness of each experience. I have also consciously chosen to use oral history quotes extensively and to treat them as blocked quotes wherever possible to ensure that their recollections and reflections are properly highlighted and that the "voices" are not lost in the text. 


\section{Chapter 2 "Taking the Plunge": Professors Certify the Carleton University Academic Staff Association}

\section{Introduction}

The lead headline for the December 1974 issue of CUASA News was provocative:

"C.U.A.S.A. Takes the Plunge???" Anyone intrigued enough by the question would have found the answer on the front page of the newsletter in the "President's Report." As Carleton University Academic Staff Association (CUASA) president, Professor Jill Vickers, explained in her column, the university community was facing a "bleak financial picture" due to a reduction in government funding and a handful of the academic staff at Carleton had taken the unprecedented step of considering the formation of a faculty union in the face of potential budget and staffing cuts. ${ }^{1}$ However, if Carleton professors took "the plunge" and unionized, they would be founders of the first academic staff union in Ontario as well as participants in the initial "wave" of faculty unionization in Canadaroles that potentially represented a fundamental change in occupational status. ${ }^{2}$ Over the next five months, faculty actively debated the contentious issue of unionization.

Opponents to the certification of CUASA as the faculty bargaining agent argued that this form of collective action was "inconsistent with academic life" while supporters countered that the "rule of law" would strengthen rather than weaken their position at the university. ${ }^{3}$ By mid-April 1975, organizers had successfully countered this resistance and

\footnotetext{
${ }^{1}$ Jill Vickers, "President's Report," CUASA News 5, no. 2 (December 1974): 1. Note: All the CUASA News issues consulted for this thesis are posted on the CUASA website at http:/www.cuasa.ca/services/newsletter.php. As such, this information will only be cited once, in this footnote. Subsequent footnotes will be referenced back to FN 1, Chapter 2.

${ }^{2}$ Rastin, "Organizing Tactics," 102-03

${ }^{3}$ Thomas K. Rymes, "Threats from Within," Forum (letters to the editor) This Week Times Two 11, no. 6 (Friday, February 7, 1975). Note: All the issues of This Week Times Two consulted for this thesis are located in the Archives and Research Collections of the Carleton University Library. As such, this
} 
won an Ontario Labour Relations Board (OLRB) representation vote; ${ }^{4}$ two months later, the OLRB issued CUASA a certificate to bargain collectively on behalf of faculty. The formal certification campaign had lasted barely four months and for some professors, unionization seemed to have happened "overnight.",

The purpose of this chapter is to examine the transition Carleton professors made from being members of a staff association to belonging to a labour union. Although faculty interest in union formation arose quickly and unexpectedly, it will be argued that the labour activism of Carleton academic staff had actually begun in the 1950s, as the first generation of professors attempted to gain a more authoritative and influential role in a university that had been formally designed as a corporation rather than a collegial "community of scholars." Certain situational factors such as the rise in white-collar unions across Canada, a new president with an unpopular leadership style and a looming budget deficit, contributed in varying degrees to the rapid unionization of Carleton faculty in the mid-1970s. ${ }^{6}$ However, both opponents and supporters of certification were motivated by a long-standing concern for occupational status. Ultimately, organizers mobilized enough support by arguing that a certified staff association was compatible

information will be cited only once, in this footnote. All subsequent citations will be referenced back to FN 3, Chapter 2. This Week Times Two is not paginated.

${ }^{4}$ As per Section 7, (1-3) of the Ontario Labour Relations Act of 1970, if the Board is satisfied that the percentage of employees in the bargaining unit that are members is not less and $35 \%$ and not more than $65 \%$, then the Board may call a representation vote. If after the ballots are cast, more than $50 \%$ of the ballots cast are cast in favour of the trade union, and in other cases, if the Board is satisfied that more than $65 \%$ of the employees in the bargaining unit are members of the trade union, then the Board will certify the union as the bargaining agent of the employees in the bargaining unit. The Act is not more explicit about the process of conducting the vote but, based on the CUASA experience, it appears that the Board called the vote and sent its representatives to Ottawa, who oversaw the vote and were responsible for tabulating the results. Essentially, if the Board had any doubts as to the number of employees who were in favour of certification (i.e., in the area between 35 and $65 \%$ ), then it could call a vote. The Labour Relations Act was amended on July 18, 1975 and the percentages for determining the possibility of a vote were changed to $45 \%$ and 55\%. Labour Relations Act, RSO 1970, c232.

${ }^{5}$ A. Brook, oral history.

${ }^{6}$ See "Historiography," Chapter 1 of this thesis, for overview of the factors cited as triggers for faculty unionization. 
with academic "prestige" - it would be a "boon" rather than a blight in terms of securing rights and equitable working conditions. Missing from the public debate, however, were references to the status of female faculty despite the fact that the current CUASA president, Jill Vickers, was personally motivated by the inequities faced by women on campus. This omission was deliberate - most faculty were men and an appeal for women's rights would not necessarily have resonated with them at a time when university teaching and research was still very much male-dominated work. On the whole, however, both gender and status were influential factors in the unionization of faculty at Carleton.

"They Were the University”: Creating a Community of Scholars (1942-1973)

Faculty unionization in Canada was considered a significant enough change in university labour relations during the 1970 s to be discussed not only in the national newspaper the Globe and Mail but also in other smaller publications across the country. On April 8, 1975 the New Westminster Columbian, a British Columbia newspaper, ran a story announcing "University Bargaining. 'An Established Fact'."7 The article singled out the Carleton University Academic Staff Association (CUASA) as the "first professional group in Ontario" to apply for and receive certification. It included a statement from Jill Vickers, attributing this decision to the possibility of faculty layoffs when the university was facing the possibility of an operating deficit due to a significant reduction in provincial funding. As a result of this threat, professors had begun to understand that "we

7 "University Bargaining. 'An Established Fact'," New Westminster Columbian, April 8, 1975, Office of the President fonds, Pres. 233-4, Carleton University Archives. The president's files included a number of clippings from newspapers published between April and June 1975. 
are employees ... and for some it was a real blow to the ego." ${ }^{8}$ Whether her colleagues agreed completely with Vickers's analysis or not, many Carleton professors did see themselves as occupying a privileged place on campus. ${ }^{9}$ Faculty members did not deny the fact that they earned a salary but some argued that they could not work "for" the university because "they were the university." 10 This understanding of their occupational status was partly the product of the traditional definition of a university as a democratic community of scholars - a form of academic life that Carleton professors had been striving to create since the early 1950s within the constraints of an inherently hierarchical workplace that had legally identified them as employees since the creation of the university. ${ }^{11}$ While they never achieved this ideal version of academia, between 1942 and 1973 their collective attempts to establish an academic community had contributed to some improvement in their institutional status; it also laid the foundation for unionization.

Although the founders of Carleton College had been guided in many of their decisions by the "usual custom in the Universities" since $1942,{ }^{12}$ the official contours of academic life at the college were formally mapped out for the first time in the provisions of The Act Respecting The Ottawa Association for the Advancement of Learning ("the Carleton College Charter"), which received provincial assent on April 10, $1952 .{ }^{13}$ In the

\footnotetext{
${ }^{8}$ Ibid.

${ }^{9}$ A. Brook, oral history. Brook explains that relative to support staff, he and his academic colleagues "certainly recognized that however vulnerable we felt, they [support staff] were way more vulnerable than we were."

${ }^{10}$ B. Neatby, oral history.

${ }^{11}$ See F. Mackinnon, "The University: Community or Utility," Canadian Public Administration 3, no. 4 December 1960): 339.

12 OAAL, Minutes of the 26th Meeting of the BOG, October 17, 1946, 2, FN 1, Chapter 1. These customs would include, for example, the establishment of a senate, the appointment of a chancellor and the hiring of faculty. The Ottawa Association for the Advancement of Learning was the original governing body for Carleton College.

${ }^{13}$ Carleton University Act, SO 1952, c117, http://www6.carleton.ca/secretariat/carleton-universityact/, accessed November 26, 2013. The original act is now known as the Carleton University Act. Board of Governors fonds, Carleton University Corporate Archives. Note: The Act is posted on the Carleton
} 
tradition of $20^{\text {th }}$ century Ontario liberal universities,${ }^{14}$ the mandate of the college included the "advancement of learning" and the "dissemination of knowledge" and the law divided the operational responsibilities for achieving these goals between two bodies, the lay Board of Governors ("the Board") and the Senate. ${ }^{15}$ While both groups were given decision-making powers, the lines of authority were clearly drawn. The selfperpetuating ${ }^{16}$ board was designated as the corporate head of the university and governors had full fiduciary duty for every aspect of institutional "work, affairs and business", including the hiring and firing of staff. ${ }^{17}$ Legally, the role of the Senate was extensive but nonetheless limited to the oversight of Carleton's academic well-being which included responsibility for program development (both undergraduate and graduate), the setting of examinations and the conferring of degrees. The university president was the "traditional link" between the two corporate bodies - the channel for exchanging information, decisions and respective points of view-as well as the chief executive officer to whom the board delegated day-to-day administrative authority. His or her authority extended to responsibility for all personnel and, in fact, the board could not make any employee-related decision without the recommendation of the university

University website and always accessed through this URL. As such, this information will only be cited once. Subsequent footnotes will be reference back to FN 13, Chapter 2.

${ }^{14}$ Rene Hurtubise and Donald C. Rowat, The University, Society and Government. The Report of the Commission on the Relations Between Universities and Governments (Ottawa: University of Ottawa Press, 1970).

${ }^{15}$ Carleton University Act, FN 13, Chapter 2. See Donald C. Rowat, "Faculty Participation in Canadian University Government," AAUP Bulletin 43, no. 3 (September 1957): 461-76. See also Glen A. Jones, Theresa Shanahan and Paul Goyan, "Traditional Governance Structures-Current Policy Pressures: The Academic Senate and Canadian Universities," Tertiary Education and Management 8, no. 1 (January 2002): $135-48$.

${ }^{16}$ Rowat, "Faculty Participation in Canadian University Government," 466.

${ }^{17}$ Carleton University Act, "Government of University vested in Board," FN 13, Chapter 2. 
president. By the mid-1950s, the majority of Canadian universities had a bicameral form of governance. ${ }^{18}$

The charter created an organizational hierarchy. The Board was vested with ultimate corporate power and while mid-20th century Canadian senates usually operated at arm's length from the governing board because the membership of the two bodies "rarely" overlapped, the composition of Carleton's first Senate under the charter limited the group's independence from the Board. ${ }^{19}$ Senators at Carleton were drawn from key constituencies found within and outside the university: senior administrators including deans and the president (all ex officio); the current cohort of full professors; and board appointees who were considered "distinguished Canadians" 20 and "respected intellectuals" ${ }^{21}$ such as Dr. D. Kaye Lamb, Canada's dominion archivist and national librarian. However, this "group of senior scholars" did not wholly represent the academic community — no one was elected, the board maintained a presence on Senate through its appointees and as retired Carleton professor Naomi Griffiths remembers, when she

${ }^{18}$ Jones, Shanahan and Goyan, "Traditional Governance Structures," 136.

${ }^{19}$ Rowat, "Faculty Participation in Canadian University Government," 465. President H.M. Tory first proposed a senatus academicus for Carleton College on May 1, 1946 that was "an advisory committee" for the Board of Governors for the Ottawa Association for the Advancement of Learning. At this meeting it was proposed that Senate members consist of "five members selected annually from the Board of Governors, the members of the educational directories for the Department of Journalism and the Institute of Public Administration and certain members of the teaching staff selected by the President." On June 11, 1946, the board voted to change the number of board appointees to eight and that these should "automatically be the eight members that would retire at the end of the year. This would give each member of the Board of Governors two years of service on the Board before reaching the Senate." At a subsequent Board meeting on May 5, 1949, it was proposed that the members include "the President ex officio [sic] as chairman, Professors on the teaching staff and such other members of the instructional staff and others as may be appointed by the Board on the recommendations of the Senate." These additional members were to be "four distinguished Canadians-Dr. F. J. Alcock, Mr. Walter Herbert, Dr. J. Kay Lamb and Dr. R.A.

MacKay." OAAL, Minutes of the 22nd Meeting of the BOG, May 1, 1946, 1; OAAL, Minutes of the 23rd Meeting of the Board of Governors, June 11, 1946 (these minutes are incorrectly listed as June 7, 1946), 115, FN 1, Chapter 1.

${ }^{20}$ OAAL, Minutes of the 48th Meeting of the BOG, May 5, 1949, 3, FN 1, Chapter 1.

${ }^{21}$ Neatby and McEown, Creating Carleton, 41. 
started as a lecturer in 1959 , only senior professors sat at Senate. ${ }^{22}$ As a result, the autonomy of senators was curtailed and, in the early years, "there was no talk of professors controlling the Senate or even of electing some of their colleagues to this academic body."23

The first generation of Carleton professors was not necessarily convinced that this legalized approach to institutional governance was compatible with academic life and at least one professor was publicly vocal with his concerns. ${ }^{24}$ Donald Rowat was a professor of political science at Carleton from 1950 to 1992 and published several articles on Canadian university governance and higher education in Canada. ${ }^{25}$ Based on his extensive survey of Canadian university governments, in 1955 Rowat concluded that, like their American counterparts, English Canadian universities were essentially corporations managed "by outsiders" in contrast to those in Britain that were "governed entirely from within" by members of the academic community. ${ }^{26}$ The inherent danger of this North American form of corporate governance, he argued, was that the lay board members sitting on the "controlling bodies" would mistake the true function of a university and treat it as "a vocational school or an adult education venture, or even a football club"

\footnotetext{
${ }^{22}$ N. Griffiths, retired professor, Carleton University, in oral history interview with the author, March 26, 2012.

${ }^{23}$ Neatby and McEown Creating Carleton, 41.

${ }^{24}$ Donald C. Rowat, "The Government of Canadian Universities," Culture. A Quarterly Review. Religious and Secular Sciences in Canada 17 (1956), 268-83 and 364-78. A condensed version of this two-part article later appeared in the AAUP Bulletin.

${ }^{25}$ Donald Rowat, obituary, http://www.legacy.com/obituaries/remembering/obituary.aspx?page=lifestory\&pid=120929380, accessed November 26, 2013. In addition to his article cited in FNs 16 and 24, Chapter 1, see also N.A.M. MacKenzie and D.C. Rowat, "The Federal Government and Higher Education in Canada," The Canadian Journal of Economics and Political Science 16, no. 3 (August 1950): 353-70.

${ }^{26}$ Rowat, "Faculty Participation in Canadian University Government," 470-71. This model was first introduced at the University of Toronto in 1906 upon the recommendation of the Royal Commission on the University of Toronto (the Flavelle Commission).
} 
rather than an institution where scholars could dedicate themselves freely to "pushing forward the frontiers of knowledge and searching for the truth without fear or favor." 27

Rowat maintained that such different understandings of the nature of academic work could be difficult to reconcile. Board members and faculty were not required to interact formally on a regular basis, and although a key part of the president's role was to act as a "funnel" between the Board and the Senate, he questioned the effectiveness of this form of communication in representing or protecting the interests of faculty given that board members "outnumbered" the president, who they appointed and could dismiss at will. Moreover, the "hierarchical and autocratic structure of control" ensured that faculty members were "regarded as nothing more than employees of boards" and all key institutional positions were held by senior university officials ex officio rather than by elected members of the academic community. ${ }^{28}$ As such, Canadian universities were not democratic, self-governing communities where scholars automatically had the freedom to "set their own objectives and decide their own activities." ${ }^{, 29}$ Rowat believed that the corporate approach to management could (and should) be limited and that faculty had the knowledge and expertise to play a greater role in university decision-making and governance through the election of professors to the board, i.e., the university could be a more democratic institution.

Rowat was not alone in his discontent with the status of Canadian academics during this period. Collectively, Carleton faculty supported efforts to improve the overall standing of professors through their membership in the Canadian Association of

\footnotetext{
${ }^{27}$ Ibid., 472.

${ }^{28}$ Ibid., 472-74.

${ }^{29}$ Ibid., 475.
} 
University Teachers (CAUT) ${ }^{30}$ Professors from a number of Canadian universities had formed this association to "promote" their interests in the years following World War II. ${ }^{31}$ The founding group believed that their occupational status needed to significantly improve and faculty at the college had formed the Carleton College Academic Staff Association (CCASA) in 1951 specifically so that they could become charter members of CAUT.$^{32}$ In turn, this would allow them to support efforts to improve working conditions and perhaps to gain the "prestige" of being university teachers and researchers while Carleton was still a college. ${ }^{33}$ The issue of university governance was addressed in one of the early issues of the CAUT Bulletin and, like Rowat, author F.M. Salter thought that the current hierarchical organization was the antithesis of "an association of scholars.",34 However, in the early years members of the CAUT, executive chose to focus their efforts primarily on the improvement of salaries and benefits rather reforming university governance even though they recognized that "the administration of Canadian

${ }^{30}$ According to Donald C. Savage (the executive director of CAUT from 1972 to 1997), the first generation of CAUT members made a considerable effort to "create a more constitutional form of governance through reform of the Senate and the Board of Governors ... [they] hoped that elected faculty in the Senate would dominate the university. Their model was Oxbridge or Harvard. Their hope for the professoriate was the creation of a self-governing guild along the lines of the medical and legal professions." Donald C. Savage, "How and Why the CAUT Become Involved in Collective Bargaining," Interchange 25, no. 1 (1994): 55-63.

${ }^{31}$ Canadian Association of University Teachers, The University Teacher and the Crisis in Higher Education in Canada. A Brief Presented to the Royal Commission by the Canadian Association of University Teachers (Ottawa: 1956): 1.

${ }^{32}$ Neatby and McEown, Creating Carleton, 58. The Carleton faculty association seems to stand out from associations at other Canadian university, such as the University of Toronto and the University of British Columbia. Both Nelson and Bruneau describe the early incarnations of their associations as more social clubs than advocacy group. Nelson says that, "until the late 1960s the character of the Toronto faculty association was markedly different from that of later years. It was very much a professors' organization, not only underfunded and casual in its operations but amateurish and uncritical of the paternalism of the day." Nelson, Searching for Power, 18.

${ }^{33}$ Ibid.

${ }^{34}$ F.M. Salter, "The University in a Democratic Age," Canadian Association of University Teachers Bulletin, 1953-54 Session 2, no. 1: 1-10. Professor Salter presented this paper at the NCCU (National Conference of Canadian Universities and Colleges and the forerunner to the Association of Universities and Colleges of Canada) conference in June 1953. He was a member of the Department of English at the University of Alberta. 
universities is conducted more on the order of business corporations whose purpose it is to minster to the needs of the body than of associations concerned with the needs of the mind and spirit.",35

Perhaps the best articulation of the concerns regarding compensation was contained in the CAUT brief submitted to the Royal Commission on Canada's Economic Prospects (the "Gordon Commission") in 1956. The federal commission had been established in 1955 to assess both the possibilities and problems related to "the long-term prospects of the Canadian economy" and CAUT was one of hundreds of organizations from which the commissioners received submissions. ${ }^{36}$ Presented by its president, V.C. Fowke, and secretary, J. Percy Smith, the CAUT submission supported an expanded role for universities. The authors argued that universities played a vital role in economic development and productivity through the on-going creation and dissemination of knowledge-i.e., both teaching and research were "indispensable functions," approach to academic work that in fact represented a significant shift from the role of universities in the $19^{\text {th }}$ and early $20^{\text {th }}$ century when institutions were focused on undergraduate teaching and training Canada's elite young men to take on leadership roles in business, the state or the church by introducing them to existing or "static" knowledge. ${ }^{38}$ CAUT's position was that Canada was going to find it difficult "to recruit

\footnotetext{
${ }^{35}$ Canadian Association of University Teachers, The University Teacher and the Crisis of Higher Education in Canada, 8.

${ }^{36}$ Royal Commission on Canada's Economic Prospects, Preliminary Report, (Ottawa: December, 1956), front piece.

${ }^{37}$ Canadian Association of University Teachers, The University Teacher and the Crisis of Higher Education, 40.

${ }^{38}$ Others shared this viewpoint. See for example, Claude Bissell, "The Problems and Opportunities of Canada's Universities," Canada's Universities in a New Age, Proceedings of a Conference Held by the National Conference of Canadian Universities and Colleges, Ottawa, November 13-15, 1961 (Ottawa: Le Droit, 1962): 7. In his keynote address to the conference, Bissell (Carleton's president from 1956 to 1958) stated that, "Traditionally ...the university filled an essential, but repetitive and creative role of training
} 
and to hold the best quality personnel" to universities because faculty salaries were not competitive with those of similar occupations in either the public or private sector. While the real income per Canadian worker had risen by 67\% between 1927 and 1954, the current salaries of academic staff were "equal to that of a generation ago" and too low to compensate professors adequately for their cost-of-living which included additional expenses that made their work similar to that of self-employed professionals such as doctors and lawyers. Likewise, fringe benefits (e.g., pensions) and other important working conditions such as the standard workweek were not comparable to those offered by other employers and so remuneration represented a real disincentive for entering or staying in the field. ${ }^{39}$ Faced with the projected $100 \%$ increase in student enrolments over the next decade that had been announced at the annual conference of the National Conference of Canadian Universities (NCCU) that same year, Canadians would soon experience a "crisis in higher education" if the concomitant demand for teaching and research personnel could not be met. These poor conditions existed partly because, as had been the case historically, the present level of government funding was inadequate to meet the operating needs of Canadian universities. However, CAUT suggested that this situation could be improved if both the provincial and federal governments increased financial support for higher education. ${ }^{40}$

each new generation in a basic set of ideas and techniques. This involved a relatively static body of knowledge and a formalized and unchanging way of presenting it. Now, it is said, all that is changed; electronic devises have turned the world into a vast communication enterprise ... knowledge outstrips textbooks and classroom techniques." See also A.B. McKillop, Matters of Mind: The University in Ontario 1791-1951 (Toronto, Buffalo, London: University of Toronto Press). McKillop's overview of higher education in Ontario discusses in depth the shift in curricula in the province's universities.

${ }^{39}$ Ibid., 21. See also A.R.M. Lower, “The Canadian University: Time for a New Deal," Queen's Quarterly 62 (Fall 1955): 250. Lower contends that, "You are not going to get any high proportion of first class men under present university conditions of salary and employment, as compared to other callings. The "prof" after all is a mere hired hand: unless he has an ardent sense of vocation."

${ }^{40}$ Ibid., 22 and 40-41. 
This general assessment of the relatively low status of university teachers and researchers is validated by the experiences of some Carleton professors during this period. For example, Blair Neatby, professor emeritus and historian, began his career in the early 1950s and not only were salaries considered poor by comparison to those of professionals such as lawyers and engineers but he found himself sharing an office, the departmental phone and secretarial services and, more importantly, had little or no access to travel or research funds. ${ }^{41}$ He believes that job loss was not an issue during this period because "nobody with ambition would think of becoming an academic." 42 Although Neatby was not at Carleton in these early years, apparently the college academic staff had similar experiences - low wages, "cramped physical conditions and ... limited financial resources." ${ }^{43}$ The majority of academics were men (72\% in 1953) during this period and for their female colleagues, salaries and other working conditions might well have been poorer. ${ }^{44}$ In contrast, when the CAUT made its 1967 submission to the Royal Commission on the Status of Women, the data on earnings differentials revealed that the mean salary for men in the academic profession in Canada was $\$ 10,690$ while women

\footnotetext{
${ }^{41}$ Neatby, "The Academic Profession: An Historical Perspective. 'Communities of Scholars in Ontario'," in The Professoriate-Occupation in Crisis, (Toronto: The Ontario Institute for Studies in Education, 1985), 11. Neatby did not begin his career at Carleton. His first appointment was at the University of Prince Edward Island. He then took a post at the University of British Columbia before arriving at Carleton in 1965. However, his memories are compatible with the general description of academic life that appeared in the CAUT submission to the Gordon Commission.

${ }^{42}$ Ibid. According to Sylvia Ostry the number of professors increased significantly during this period, which perhaps indicates that it could have been a more attractive occupation during this period than Neatby remembers. Ostry, The Occupational Composition of the Canadian Labour Force, 19.

${ }^{43}$ Neatby and McEown, Creating Carleton, 42 and 46.

${ }^{44}$ Jill McCalla Vickers and June Adam, but can you type? Canadian Universities and the Status of Women (Buffalo: Clarke, Irwin \& Company Limited in association with the Canadian Association of University Teachers, 1977), 114. A brief review of the Carleton College and University Board minutes between 1942 and 1973 reveals that the majority of new faculty hires that the Board approved in this period were men. As Vickers and Adam point out, the median salary for professors in the mid-1950s was $\$ 5,892$ and typically women were paid less than their male colleagues. Ibid., 116.
} 
received $\$ 8,428$ and more than half of this difference was attributable to "sex

difference." 45

Despite the constraints imposed by the hierarchical nature of the college's organizational structure and the challenges created by poor working conditions as well as a lack of resources, in the early to mid-1950s Carleton academics appear to have treated the college as a scholarly community rather than as a business enterprise. As Neatby and Don McEown explain in their history of Carleton, the college's relatively small, mostly male, "professoriate" grew to become a closely-knit group ${ }^{46}$ that was united by the nature of its work as well as a commitment to the long-term success of the college. Like academic staff at other Canadian universities in the mid- $20^{\text {th }}$ century, professors at Carleton College defined scholarship in terms of specific activities and principles. Their primary responsibilities included teaching and, increasingly independent research, but they also took on administrative duties and participated in professional organizations including the CCASA. ${ }^{47}$ They were guided in this work by the long-standing scholarly principles of academic freedom and collegiality. Academic freedom gave individual faculty members the right to work autonomously and make a wide range of decisions about both the courses they taught as well as their research projects. ${ }^{48}$ Collegiality was

\footnotetext{
${ }^{45}$ The Canadian Association of University Teachers, A Comparison of Men's and Women's Salaries and Employment Fringe Benefits in the Academic Profession (Ottawa: Canadian Association of University Teachers, 1967), 4.

${ }^{46}$ Neatby and McEown, Creating Carleton, 58. In 1952, there were forty-two full-time faculty working at Carleton College.

${ }^{47}$ Ibid., 44.

${ }^{48}$ Michiel Horn, Academic Freedom in Canada: A History (Toronto, Buffalo, New York: University of Toronto Press, 1999): 4. Horn suggests that "scholars have two main meanings for academic freedom: the freedom of universities from external control, and the freedom of teachers and researchers to do their work." In addition, the CAUT Handbook (1971) defined academic freedom as, "the right within the university to decide who shall teach, who shall be taught, and what shall be studied, taught, or published. Because a university's essential concerns are intellectual, academic freedom involves the right of appointment of staff or admission of students regardless of race, sex, religion, or politics. It involves the
} 
defined as the long-standing practice of professors acting together as peers and jointly making the decisions - at the departmental, faculty and Senate levels - related to all academic matters on campus, a tradition that was to some extent encoded in the college charter. $^{49}$

The professors' sense of belonging to a scholarly community was reinforced by their collective dedication to establishing the "academic respectability" of the college. Faculty members were determined to ensure that Carleton met certain standards common to the Canadian academic community, most particularly those related to program offerings and credentials. As such, they devoted considerable time and energy to developing curricula that provided both intellectual depth and breadth and to ensuring that the $\mathrm{PhD}$ became the entry credential for academic work at the college-a goal compatible with the Board of Governors' long-term commitment to the "high quality of academic appointments. ${ }^{, 50}$ Not all their activities were work-related, however, and they also spent time together socially—chatting over coffee, attending Scottish country dancing parties at the home of chief librarian Hilda Gifford and sharing cottages in the Gatineau Hills - and these activities further strengthened the bonds of community at a time when the college was somewhat isolated from the broader Ottawa society. ${ }^{51}$

According to Neatby and McEown, the faculty and lay members of the Board of Governors generally recognized their respective jurisdictions during these early years.

right to criticize the university." Canadian Association of University Teachers, C.A.U.T. Handbook, (Ottawa: Canadian Association of University Teachers, 1971), 19.

${ }^{49}$ For definitions of collegiality, see Rastin, "Organizing Tactics"; and John H. Van de Graaff, Burton R. Clark, Dorotea Furth, Dietrich Goldschmidt and Donald F. Wheeler, Academic Power. Patterns of Authority in Seven National Systems of Higher Education (New York: Praeger Publishers, 1978): 2 and 83.

${ }^{50}$ OAAL, Minutes of the 29th Meeting of the BOG, September 15, 1948, 2, FN 1, Chapter 1. In the 1950s, the student newspaper The Carleton would feature short notices about professors who were taking time to complete studies.

${ }^{51}$ Neatby and McEown, Creating Carleton, 49. 
Typically, board members did not interfere in academic decision-making because the lay leaders understood the professors" "right to make academic decisions" such as choosing course content, designing exams and handing out marks. These decisions appear to have been made collegially or "from the bottom up," starting at the departmental level and moving upwards through the faculties, to the Senate and the president. ${ }^{52}$ Likewise, professors respected the Board's responsibility for legal and financial matters. For example, although a more competitive compensation package would have helped in faculty recruitment efforts in the early 1950s — and thus boosted academic legitimacy while improving the standard of living for current academic staff-apparently professors were prepared to assume that Board of Governors members would have improved salaries and benefits if possible, even though the academic staff knew that like their colleagues across Canada they were "underpaid and overworked. ${ }^{, 53}$ However, the faculty members would challenge the Board if they believed that it had acted arbitrarily or excluded them from participating in decisions that were essentially academic in nature and in which professors believed they had a right to be included such as the appointment of the new president in $1955 .{ }^{54}$ Professors might not have been "militant" but they did

\footnotetext{
${ }^{52}$ Neatby and McEown do not define the decision-making process during this period and Senate minutes are unavailable. However, Neatby also does not indicate in his oral history that this process was not in place and certainly he, Naomi Griffiths and David Coll all refer to departmental involvement in program decision-making. Nelson describes a similar division of duties at the University of Toronto in the same period. Nelson, Search for Faculty Power, 23.

${ }_{53}$ N.A.M. MacKenzie and D.C. Rowat, "The Federal Government and Higher Education in Canada," The Canadian Journal of Economics and Political Science/Revue Canadienne d'Economique et de Science Politique 16, no. 3 (August 1950): 358.

${ }^{54}$ Neatby and McEown, Creating Carleton, 89 . That year a committee chaired by Donald Rowat advocated for greater "consultation" with faculty on issues that impacted the "academic development" of Carleton. CU, Minutes of the $93^{\text {rd }}$ Meeting of the BOG, October 20, 1955, 3, FN 1, Chapter 1. The motion put before the Board at that meeting by the Senate stated that the senators "therefore respectfully request that, before the Board of Governors exercises its authority to appoint a President, arrangements be made for consultation with the Faculty in this important matter."
} 
actively attempt to gain respect for what they perceived to be the boundaries of their work.

As such, although Carleton professors were not fully self-governing during the early and mid-1950s, they created a scholarly community by working together as peers with shared functions and goals. There were "hard times" as they struggled to build a reputable institution during a period when student fees and private donations could not adequately meet the college's financial needs and the board had the authority to and did act unilaterally. However, their common experiences contributed to tremendous collective pride and an on-going dedication to the common cause; occupational prestige might have been low in the priorities of Canadian professors but, in this first phase of community building, those at the college seemed to have enjoyed the special status of belonging to the early generation of "Carletonians."

Efforts to gain "academic legitimacy" paid off in the late 1950s. In 1957, the Carleton University Act was passed, completing the legal transition from college to university. In addition, that same year Carleton's current president Claude Bissell persuaded the board to raise faculty salaries by $27 \% .{ }^{55}$ This increase would bring salaries "in line with high school salaries and with salaries available to research scientists in the National Research Council" as well as those at the University of Toronto. ${ }^{56}$ As a result, Carleton would be able to more effectively compete for the "qualified" academic staff that would be needed to develop current programs as well as introduce the new graduate and research offerings there were expected to be in demand at Carleton as well as

\footnotetext{
${ }^{55} \mathrm{CU}$, Minutes of the $105^{\text {th }}$ Meeting of the BOG, April 18, 1957, 1-2, FN 1, Chapter 1.

${ }^{56}$ Ibid.
} 
universities across Canada. ${ }^{57}$ Within two years, the "Carletonians" had a new campus and president as well as a fresh cohort of colleagues and the timing of these changes was fortuitous. It coincided with significant shifts in Canadian public policy regarding higher education that had been slowly evolving since the end of World War II and were partly the result of the recommendations of both the Gordon Commission and the Massey Commission ${ }^{58}$ as well as the persistent advocacy efforts of groups such as the National Conference of Canadian Universities and Colleges (NCCUC) and CAUT.

These changes promised to improve considerably the financial fortunes of Canadian universities. Until the 1950s, higher education had not been a public priority in Canada. The provinces had gained constitutional responsibility for public education with Confederation, but since the $19^{\text {th }}$ century funding schemes varied considerably across the country except in one respect: grants for operating expenses were chronically low and there was little money allocated for research or capital projects. ${ }^{59}$ The federal government had provided some financial support for research and other projects since 1916 through the National Research Council and various departments ${ }^{60}$ as well as funding the war veterans program but overall public funding never represented more than $52 \%$ of the

\footnotetext{
${ }^{57}$ Neatby and McEown, Creating Carleton, 91.

${ }^{58}$ The Massey Commission was the Royal Commission on National Development in the Arts, Letters and Sciences led by Vincent Massey. It made a number of significant recommendations for cultural development in Canada including greater financial support for education by the Government of Canada. See McKillop, Matters of Mind, 563.

${ }^{59}$ David M. Cameron, More Than an Academic Question: Universities, Government and Public Policy in Canada, (Halifax: The Institute for Research on Public Policy/L'Institut de Recherches Politiques, 1991), see Part I: "The Making of a Crisis." See also McKenzie and Rowat, "The Federal Government and Higher Education."

${ }^{60}$ For example, in 1946 Carleton College received an extra $\$ 150$ from the Department of Veterans Affairs for the purchase of equipment "in connection with the work with veterans." OAAL, Minutes of the 23rd Meeting of the BOG, June 11, 1946, 2, FN 1, Chapter 1. Professors such as Blair Neatby benefited from this program. B. Neatby, oral history.
} 
universities' annual budgets. ${ }^{61}$ Now, higher education had become of national interest and by 1960 both federal and provincial governments had begun to "invest" heavily in education at all levels: over the next decade the allocations for post-secondary education rose from $\$ 95$ to $\$ 348$ per capita. ${ }^{62}$ As a result, existing institutions could hire more staff, develop new undergraduate and graduate programs and construct additional buildings while twenty new degree-granting universities were built across the country. Students from a range of socioeconomic backgrounds flooded onto campuses in record numbers and by the end of the 1960 s enrolment had grown by $192 \% .{ }^{63}$

As Miles Wisenthal, the director general of the Institutional and Public Finance Branch of Statistics Canada, pointed out in his introduction to Education in Canada 1973, this unprecedented investment in higher education was justified in terms of national wellbeing. Of primary importance was Canada's need for well-trained workers and as a result of the improvements made in the 1960s, by the 1970s Canada had become "virtually selfsufficient with respect to its ability to educate and train the highly qualified personnel required for the management and operation of its affairs" but other "dividends" included national unity, "personal enrichment" and "artistic creativity." ${ }^{64}$ In addition, the research undertaken at universities could yield significant economic and social benefits. ${ }^{65}$ As such, the late 1950s and 1960s heralded a new phase of "expansion" for universities in contrast

${ }^{61}$ Hon. C.D. Howe, Minister of Trade and Commerce, Survey of Higher Education, 1950-1952, (Part II of the Biennial Survey of Education in Canada, 1950-1952), Dominion Bureau of Statistics, Education Division, (Ottawa: Edmond Cloutier, Queen's Printer and Controller of Stationary, 1954), 15.

${ }^{62}$ Miles Wiesthal, "Foreword," Education in Canada 1973. A Statistical Review for the Period 196061 to 1970-71, Statistics Canada, Education, Science and Culture Division (Ottawa: Information Canada, 1973).

63 Ibid.

64 Ibid.

${ }^{65}$ Neatby and McEown, Creating Carleton, 103: "Their status was also enhanced by the increased importance given to research. Professors who had been respected employees in the college years-but nonetheless employees - now found that their research skills gave them a prestige that changes their status within the university. By the end of the decade they controlled the Senate and had representatives on the Board of Governors." 
to the many previous years of "subsistence" $" 66$ and at Carleton this was a period of institutional advancement as well as one in which professors progressed to the second phase of community building and attempted to gain greater recognition for their standing on campus.

Carleton benefited substantively from the increase in government support and the years between 1958 and 1972 were ones of tremendous growth—as Don McEown was fond of saying, the campus grew "by a Carleton College a year." 67 Growing by a "college a year" meant that between 1958 and 1973, the total student population (undergraduate and graduate) rose from 1,591 to $13,649^{68}$ and on the new campus the number of buildings increased from three in 1961 to 25 in $1973 .{ }^{69}$ New undergraduate and graduate programs were developed along with research initiatives as research funding increased from $\$ 156,000$ in 1963 to $\$ 2.7$ million in 1974 — changes that had a direct impact on the scholarly community on campus. ${ }^{70}$ There was a greater demand for professors during this period and at Carleton the total number of full-time academic appointments increased tenfold between 1952 and 1969, with most of these positions being offered to men as was the case across Canada. ${ }^{71}$ Moreover, the changes to the nature of their work that had begun in the 1950s came to fruition. While some professors in the 1950 s might still have expected to have essentially a teaching career, during the 1960s being a full-time

\footnotetext{
${ }^{66}$ Wisenthal, "Foreword."

${ }^{67}$ D. McEown, oral history.

${ }^{68}$ Neatby and McEown, Creating Carleton, 211. Neatby and McEown include a table of enrolment at Carleton from 1942 to 1982.

${ }^{69}$ Ibid., 124. In 1961, the three buildings on campus were the Maxwell MacOdrum Library, the Henry Marshall Tory Building and the Norman Paterson Hall.

${ }^{70}$ According to a review of a sample of the university's financial statements from 1949 to 1977 , Carleton began to report research funding as a separate budget line item in 1963.

${ }^{71}$ Neatby and McEown, Creating Carleton, 49. By the 1973-74 academic year, the university reported a total of 598 5/6 full-time faculty members. Carleton University, Carleton University Data Book 1974-75 (Ottawa: Carleton University, 1975), 48, FN 3, Chapter 1.
} 
academic meant being both a teacher and a researcher. Despite changes to their numbers and their work, Carleton professors continued to work together collegially and build social relationships that reinforced their experience of a shared academic lifestyle. ${ }^{72}$

A national study done in the mid-1960s, by Professors Bernard Trotter, David L. McQueen and Bertrand L. Hansen, estimated that for "his pay," on average a Canadian professor spent approximately $40 \%$ of each workday during any given calendar year on "teaching, advising and counselling," $40 \%$ on "research and study," $15 \%$ on administration (both within his or her own institution and between that university and others) and $5 \%$ on "professional and other duties." ${ }^{, 73}$ As teachers, they were required to give conventional lectures or smaller seminars as well as lead weekly discussions on required readings and lecture materials, conduct labs, hold office hours and tutorials, mark all assignments and perhaps hold impromptu review sessions ${ }^{74}$ The courses could be ones that they had designed themselves and might include original or advanced content. For example, David Coll arrived on campus in the early 1960s and while he was earning Carleton's first $\mathrm{PhD}$ in engineering, he also taught—an opportunity he created for himself after a conversation with then engineering dean John Ruptash.

After about two years I'd been back [from MIT], really feeling that people needed to know more about the advanced theory that I'd acquired ... So I wandered down to this outfit that was starting, a university, that turned out to be Carleton University ... and said, "I want to teach this course." And the dean at the time was Ruptash, who said, "What makes you think you can teach that?" And when I talked back in the same sort of tone of voice to him, he said "Okay." ... well I had undergraduate and graduate students in my classes and ended up teaching the second graduating class in engineering. ${ }^{75}$

${ }^{72}$ Neatby and McEown, Creating Carleton, 149.

${ }^{73}$ Bernard Trotter, David L. McQueen and Bertrand L. Hansen, "The Ten O'clock Scholar? What a Professor Does for His Pay," CAUT Bulletin ACPU (January 1973): 7. This report was based on research conducted in 1967.

${ }^{74}$ Ibid.

${ }^{75}$ D. Coll, oral history. 
As researchers, professors designed and conducted their own original, empirical studies in addition to supervising that of their graduate students and staying up-to-date with and applying the research findings of their own disciplines. They had considerable control over these projects but were expected to work to current academic standards and there was increasing pressure to "publish [their results] frequently" in scholarly, peer reviewed journals, not only to participate in the exchange of new knowledge but also to qualify for tenure and promotion and establish both their own reputation as well as that of the university. ${ }^{76}$ Administration could include activities such as attending departmental meetings, sitting on departmental, faculty or university committees as well as being appointed as departmental chair or to the Senate and so responsible for overseeing the department including the work of support staff. ${ }^{77}$ Professional duties would include participation in discipline-related organizations such as scholarly societies as well as occupational associations such as CUASA, the Ontario Confederation of University Faculty Associations (OCUFA) and CAUT. For some of the younger professors of this period, such as historian Naomi Griffiths, this standard workload was even heavier as they worked to finish their PhDs. When Griffith was appointed as a lecturer in 1962, she knew that this research degree was considered de rigueur. ${ }^{78}$ She had begun her doctorate before being hired at Carleton but been unable to finish her studies after her supervisor suffered a stroke.

\footnotetext{
${ }^{76}$ Gaby Weiner, "Scholarship, Disciplinary Hegemony and Power in Academic Publishing," a paper presented at the European Conference for Educational Research, University of Ljubljana, Slovenia, September 17-20, 1998, accessed March 29, http://www.leeds.ac.uk/educol/documents/000000795.htm, 2012. See also Neatby and McEown, Creating Carleton, 148 and the CACUL submission to the Bladen Commission on the Cost of Higher Education, 2.

${ }^{77}$ As Neatby and McEown indicate, in 1963, ten seats were assigned for associate and assistant professors as well as lecturers. Neatby and McEown, Creating Carleton, 149.

${ }^{78} \mathrm{CU}$, Minutes or the $140^{\text {th }}$ Meeting of the BOG, June 4, 1962, 3, FN 1, Chapter 1.
} 
I needed to earn for my family and could not continue [and] the London University did nothing ... I had met David Farr before and I wrote to him and said that that had happened ... and that's how I couldn't go with my PhD, it had been interrupted and ... it was Carleton in [the] person of Stan Mealing who insisted because he said to me, "You're a woman and you need your doctorate otherwise you will not continue in academic life.",79

Even as a college, Carleton had offered faculty the chance to pursue an academic career similar to those at Canadian universities, according to an age-old and widespread model that is still largely in force today. Opportunities for advancement continued to be structured by a system of rankings and promotions that had existed in some form at most universities in Canada for decades and had been used at Carleton since the 1940s. ${ }^{80}$ Professors were hired into one of two tracks: non-tenure or tenure. Those in the nontenure track stream were employed under contract for a specified length of time. Those on the tenure ${ }^{81}$ track were hired into one of four ranks ordered, from highest to lowest, in terms of seniority: professor, associate professor, assistant professor and lecturer. ${ }^{82}$ Seniority was based upon a number of criteria including teaching experience, research activity and contributions to either (or both) their discipline or the profession. These criteria also formed the basis for promotion through the ranks, which was granted by the Board of Governors upon the recommendations of departmental as well as faculty committees and ultimately the president. Tenure-track professors could be appointed with or without tenure but those initially employed full-time without this status had the expectation that the "appointment without term" would be granted after a certain period of time. The decision to award tenure was made separately from that of promotion and

\footnotetext{
${ }^{79} \mathrm{~N}$. Griffiths, oral history.

${ }^{80}$ Robin Harris, "The Universities of Canada," Commonwealth Universities Yearbook (Association of Commonwealth Universities (1975): 810.

${ }^{81}$ Tenure can be defined as "permanency of appointment, the right of a faculty not to be dismissed except for cause." Canadian Association of University Teachers, C.A.U.T. Handbook (Ottawa: CAUT, 1971), 20.

${ }^{82}$ Harris, "The Universities of Canada," 810.
} 
those hired in the non-tenure track as instructors, could subsequently be hired for a tenure track position. ${ }^{83}$

Carleton did not have a written policy on tenure in the 1960s but as David Coll points out, professors understood that there were specific criteria to be met in order to advance at the university. ${ }^{84}$

To ... get tenure you had to have ... a research record and you had to have established yourself as a teacher. But then ... actually to be promoted to associate ... you couldn't be weak in any of those areas, obviously unbalanced and that sort of thing ... And to be a full professor, you had to be world-recognized.

Recognized beyond your own university ... [as an] internationally-recognized scholar. ${ }^{85}$

As the number of academic staff grew, the Board did grant salary increases - although not necessarily to the same extent as they had in 1957 . There was a shortage of qualified academic staff during the 1960s and it was critical for Carleton to be competitive with other Canadian universities, albeit both faculty and governors knew that Carleton's pay scales could be amongst the lowest in the province. ${ }^{86}$

Carleton faculty continued to operate as if they belonged to the ideal "community of scholars," working as peers on a range of academic issues although, according to Don McEown, in practice collegiality could differ from department to department.

In the sociology department, when it was at its height I think, Bruce McFarlane, John Porter, and ... Frank Valley [were there]. And what collegiality meant in the sociology department is what Frank and John and Bruce agreed to. And the rest of them just went along. But of course ... they were so attuned to academic life that

${ }^{83}$ Ibid. For example, Naomi Griffiths had this experience. N. Griffiths, oral history.

${ }^{84}$ The Board was discussing a proposal for a tenure and dismissal policy in the early 1960s. The university's first official policy was finalized in the early 1970s. See for example, CU, Minutes of the $133^{\text {rd }}$ Meeting of the BOG, February 2, 1961, 2, FN 1, Chapter 1. See also Neatby and McEown, Creating Carleton, 163-66.

${ }^{85}$ D. Coll, oral history.

${ }^{86} \mathrm{CU}$, Minutes of the $184^{\text {th }}$ Meeting of the BOG, April 12, 1967, 2, FN 1, Chapter 1 . The report of the Board's finance committee stated that, "in 1966-67, Carleton's salaries in the higher academic ranks were amongst the lowest in the province, and in spite of the proposed increases the Carleton averages would still be lower than those of other Universities, particularly in the senior ranks." 
they consulted all over the place, I mean and they were kind and gentlemen and you know, they believed in participation. ${ }^{87}$

Faculty members also discovered that collegiality could be limited; that some peers were created more equal than others: rank had "its privileges," and senior faculty would have opportunities, such as a Senate seat, that were denied to their junior colleagues. ${ }^{88}$

For many professors at this time, a sense of community on campus was still reinforced not only through their "terms and conditions" of work and collaborations on official business but also through the camaraderie and friendships that were fostered by social activities. Many attended the annual spring conference- - held for years off campus - or got to know each other at departmental potluck suppers such as those hosted for members of the history department. Newcomers like Naomi Griffiths found these events critical to a sense of collegiality. ${ }^{89}$

I can remember the first departmental meeting, we had it in David Farr's house and he came to the door saying, "I've boiled the mulled wine." ... And with such a small faculty and ... only three buildings when I came (the library, Paterson and Tory buildings) ... people knew each other in patterns of friendship, straight across the faculties and there was still in those early years not only a faculty Christmas but kids' Christmas parties because everybody had young kids at that point and it was highly social ... and the perception of that rank meant anything except a statement of professional attainment."90

Others would take regular coffee breaks together in the departmental lounges that abounded across campus. David Coll made a point of attending the morning coffee sessions held in the engineering faculty.

${ }^{87}$ D. McEown, Secretary Emeritus to the Board of Governors, Carleton University, in oral history with the author, March 14, 2013.

${ }^{88}$ N. Griffiths, oral history.

${ }^{89}$ President Maxwell MacOdrum created the Spring Conference in 1951. Initially, he intended it to be an opportunity for attendees to discuss university affairs. According to Neatby and McEown, those who attended in the 1950s felt very nostalgic about the event but in the 1960s it became an opportunity for drunkenness and many stopped attending, despite the fact that the agenda now included presentations from Carleton professors on their research. Neatby and McEown, Creating Carleton, 53 and 161-62.

${ }^{90}$ Ibid. 
It used to be that we were small enough that people would wander into the faculty lounge in the Engineering Building and chat. And ... that was ... sort of [the] legacy of Ruptash ... he would be there every morning. If you didn't show up, he came to see you. Because that's how you actually formed a philosophy for the school. $^{91}$

Another popular place to meet colleagues was the new Faculty Club. For some professors, the club was not only the undisputed social hub on campus but also a status symbol, given that membership was restricted to select Carleton staff including professors, librarians and senior administrators. Blair Neatby tried being economical by bringing a homemade lunch to work to eat at his desk but he "didn't find it pleasant, just having lunch alone or with one colleague"; he ended up going to the club every day. If he did not eat at the "History" table, there was always the opportunity to sit with other faculty members as well as the president, A.D Dunton, who was a "regular." 92 The club was a place to lunch and also a gathering spot on Friday evenings for "happy hour" that started at 4 p.m. and perhaps not finish until 10 p.m. and could include family members. ${ }^{93}$ While Neatby recalls the Friday events with distaste because colleagues drank too much and could behave badly, for others such as David Coll and his wife Margaret these get togethers were "just so nice" that being at the club on Friday night became a "tradition."94 David enjoyed interacting with faculty "from other faculties and departments" while both he and Margaret made friends who became part of a "good group that we would always meet there." 95

${ }^{91}$ D. Coll, oral history.

${ }^{92}$ B. Neatby, oral history.

${ }^{93}$ A. Brook, oral history.

${ }^{94}$ Margaret Coll, in oral history interview with the author and David Coll, May 18, 2011. I conducted this interview with both David and Margaret Coll. For one account of the experiences of faculty wives at other Canadian universities, see also Alison Prentice, "Boosting Husbands and Building Community: The Work of Twentieth-Century Faculty Wives," in Historical Identities. The Professoriate in Canada, eds. Paul Stortz and E. Lisa Panayotidis (Toronto, Buffalo, London: University of Toronto Press, 2006), 271-96.

${ }^{95}$ M. Coll, oral history. 
As Margaret explains, going to the club also represented a certain freedom for faculty wives who might very well have been stay-at-home parents at this time.

It was part of a ... very attractive social life for us all ... [and for] women, especially in the home ... and our kids were starting to grow up because we could leave them on Friday nights when I would go over and meet him at the Faculty Club ... You got to know so many people, and it wasn't divided. ${ }^{96}$

This was a period in fact when "the faculty wives" were particularly visible as a group on campus in the 1960s. Like their counterparts at other Canadian universities, some faculty spouses had formed the Faculty Wives Club and not only organized many social functions such as "parties at peoples' houses," but also held "big book sales" to raise money for projects such as student scholarships. Coll was very active as a founding member, taking on the role of club president at one point, and for her being a faculty wife was "quite a large thing," not only in terms of supporting her husband and his work at Carleton but also for meeting some of her own needs.

I think a lot of it was important ... to the men, to the professors, because they see their wives are not only active, but knowledgeable of the university itself. And ... [it] was important to the women, to make friends and to be a part of the university. ${ }^{97}$

This "good life" of teaching, research, collegial associations and extended friendships clearly contributed significantly to the sense of many professors that they were important members of the Carleton community. Creating this world, however, might have been considerably harder without the leadership of President Arnold Davidson Dunton.

"Davy" Dunton, Carleton's fifth president, oversaw the growth and development of the university from 1958 to 1972 and he could have been nightmare for professors. Whereas experts on university governance such as Donald Rowat assumed that a
${ }^{96}$ Ibid.
${ }^{97}$ Ibid. 
university president would be "chosen from the community of scholars, and is regarded as academic head of the university," 98 Dunton had studied at universities around the world but did not have a doctorate, or even a master's degree. ${ }^{99}$ Worse still, he had not worked in academia before, having been first a journalist and newspaper editor and then the chair of the Canadian Broadcasting Corporation from 1945 to $1958 .{ }^{100}$ However, the members of the Board of Governors voted unanimously to offer appoint him on July 4, $1958^{101}$ and he proved to be enormously popular with successive governors, faculty members and non-academic staff, many of whom thought that he "walked on water.",102

To some extent Dunton's success stemmed from his skills as a "people person."103 Described as a "charming gentleman" with an "active interest" in Carleton staff (academic and non-academic), he projected a sense of being closely engaged with those around him. ${ }^{104}$ Apparently he had a "phenomenal memory" and could easily remember peoples' first and last names (as well as those of spouses and children) after only one meeting as well as important aspects of their lives including their work, their families and their problems. ${ }^{105}$ Dunton did not rely on administrative staff to stay in contact with employees for him but would reach out personally to individuals, often sending handwritten "little notes" to thank someone for work well done. ${ }^{106}$ Plus, he was very much a physical presence on campus, in part because he made a point of eating regularly

\footnotetext{
${ }^{98}$ Rowat, "Faculty Participation," 472.

${ }^{99}$ Neatby and McEown, Creating Carleton, 114-15.

100 "Obituary. Davidson Dunton Distinguished Scholar had Varied Career," The Globe and Mail (Toronto, Ontario), February 9, 1987. A.14, accessed November 27, 2013, http://search.proquest.com.proxy.library.carleton.ca/canadiannews/docview/386249392/142007175244C56 $1 \mathrm{AFB} / 1$ ? accountid $=9894$.

${ }^{101} \mathrm{CU}$, Minutes of the $114^{\text {th }}$ Meeting of the BOG, July 4, 1958, 1, FN 1, Chapter 1.

${ }^{102} \mathrm{D}$. McEown, oral history.

${ }^{103}$ Ibid.

${ }^{104}$ D. McEown, oral history.

${ }^{105}$ Jill Vickers, retired professor, Carleton University, in oral history interview with the author, May 4, 2011

${ }^{106}$ D. McEown, oral history.
} 
at the faculty club and other cafeterias, sometimes being seen by faculty like Jill Vickers having three lunches in a single day.

He went to the faculty club and had a bowl of soup, he went and ate in the students' cafeteria a sandwich, and then he went to the Loeb cafeteria where most of the young faculty ate, and had a piece of pie and a coffee. And in all three places he sat at some table or another, he didn't just sit at a snobs' table or ... his table, he sat down with people and he talked and he found out what was going on on campus. ${ }^{107}$

As a result, at large events such as the reception he hosted each fall he would "know everybody in the place"-an iconic fact that stayed with staff for years. ${ }^{108}$

This leadership style translated into having a "soft hand" when managing people. ${ }^{109}$ While Dunton could be "difficult to work with" because he would give feedback indirectly rather than "frontally," 110 employees also found that he was "just superb at managing conflict" and he earned the trust of the board, faculty members and students. ${ }^{111}$ While generally he built this trust by listening and paying attention, he made two decisions that had a lasting impression on those working on campus at the time. First, he did not appoint vice-presidents because "he didn't believe in a whole lot of infrastructure,"112 instead seemingly choosing to manage from the "back of an envelope." 113 The lack of vice-presidents seems to have been welcomed by faculty, at least those who might have been suspicious that numerous layers of management might translate into greater corporate bureaucracy. As a result, the overall feeling people could have of the campus at the time was that Carleton was a very relaxed institution. ${ }^{114}$

\footnotetext{
${ }^{107}$ J. Vickers, oral history.

${ }^{108}$ Ibid.

${ }^{109}$ Ibid.

${ }^{110}$ D. McEown, oral history.

111 J. Vickers, oral history.

${ }^{112}$ Ibid.

${ }^{113}$ D. McEown, oral history.

${ }^{114}$ A. Brook, oral history.
} 
However, he did appoint bursars, planning directors and comptrollers so it was obvious to others that "he did have a whole lot of people who were doing things for him. You can't take three lunches in a day and not have people." 115 Secondly, Dunton was not seen as interfering with the academic decision making of faculty — which he could have done, particularly as he was the chair of Senate. Instead, he chose to "let them go on and on at Senate meetings till the cows come home; till they made up their mind and got something done. He also allowed the faculty to really give direction to the university." 116 Such an approach undoubtedly encouraged at least some professors to believe that Dunton recognized their authority and right to participate in university governance and perhaps even that he would support their interests with the Board of Governors.

Thus, while professors at Carleton were not formally members of a self-governing “community of scholars" during the 1960 s, some were able to participate in an academic life over which they had some control and which proved to be interesting and even enjoyable. Don McEown was part of the senior non-academic staff at this time but his feeling about this period in the university's history (and that of his wife Margaret McEown) might be shared by academics who also worked on campus at the time. Carleton was a "different place in the 50 s and 60 s because it was small, intimate ... if I had a time to go back, the 60s was [it]."117

Nonetheless, seeds of discontent were sown in these years. Davidson Dunton was well liked but faculty recognized that he also tightly controlled the operating budget and certain decisions related to personnel, in particular salaries. Moreover, the Board had not

${ }^{115}$ J. Vickers, oral history.

${ }^{116}$ D. McEown, oral history.

${ }^{117}$ Don McEown and Margaret McEown, Secretary Emeritus to the Board and retired personnel officer, Carleton University, in oral history interview with the author, July 12, 2011. 
approved any written processes related to core occupational conditions, such as tenure. Academics were not "radical" or openly hostile but CUASA continued to advocate for higher wages and input into formalized policies and procedures at a time when debates on these issues and university governance were taking place nationally, and when other occupational groups (e.g., engineers) to which professors compared themselves were publicly discussing the possibility of unionization.

\section{The Seeds of Discontent: From Collaboration to Negotiation}

The relationship between faculty and senior administrators might have been relatively harmonious during the 1960s and early 1970s but there were perennial areas of discontent that led professors to engage in labour action. Academic staff members were always interested in salary levels, and their long-term concern about other issues such as tenure reflected their recognition that some of the decision-making processes underlying working conditions were unsatisfactory, at times arbitrary and definitely not collegial. Over the course of Dunton's tenure, their approach to interacting with senior management evolved from being collaborative to being more assertive in nature, as they actively began to try and negotiate solutions with the president. Some changes in university governance introduced by the mid-1960s made the workplace more democratic; but neither these improvements nor Dunton's charisma were enough to forestall all faculty attempts to gain greater decision making authority at Carleton.

Retired faculty did not hesitate when asked if they remembered their starting salaries at Carleton: all could easily name an annual wage. This is perhaps not surprising, given that income is meaningful to employees because it contributes directly to occupational status, which in turn is determined by both identity and standing. Earnings 
established the professors' standing or prestige within the university community by quantifying the value of academic work, both individually and collectively. Salary levels also had a direct material impact on their standard of living over time, thus reinforcing their socioeconomic standing more broadly. Salary scales as well as discretionary merit pay and "special adjustments" determined a professor's total earnings at this time. ${ }^{118}$ Salary scales defined the minimum wages for each rank, and would be set by the president and the Board's finance committee in a given year. ${ }^{119}$ Merit payments were awarded in addition to base salaries in recognition of individual performance while special adjustments were "as needed." ${ }^{120}$ According to the Carleton University Act, the board would approve individual salaries (starting as well as any increases) upon the recommendation of the president and Davidson Dunton's practice was to oversee these decisions within the overall operating budget process, which "he did himself with Ab Larose the accountant." ${ }^{\prime 21}$ Administrative staff like Don McEown got used to receiving detailed memoranda about salaries from the president during the budgeting cycle.

They would be as precise as Professor So and So will get \$200 a year or more and so on. He knew what every professor in the university was doing and how they were doing it and who should be rewarded ... how much you got paid-Mr. Dunton decided personally ... He was fair and just and all the rest of those things he didn't have a bunch of hang ups about people and ... you got it if you were good.

${ }^{118}$ No evidence is available from the 1960s but in the April 1971 CUASA newsletter, the executive reported that salaries were comprised of two components: an automatic increase and a discretionary amount. CUASA Newsletter (April 1971) 1, FN 1, Chapter 2.

${ }^{119}$ For example, CU, Minutes of the $174^{\text {th }}$ Meeting of the BOG, April 7, 1966, 3, FN 1, Chapter 1. Neatby and McEown, Creating Carleton, 162. Neatby and McEown state that Dunton chose the salary levels each year in order to ensure that Carleton would be competitive when hiring new faculty but the Board minutes indicate that proposed new salary levels were brought to the Board by the finance committee.

${ }^{120}$ A review of the Board minutes between 1958 and 1972 indicates that the governors regularly approved adjustments to professors' salaries. For example, on September 15, 1960, the Board approved a salary adjustment for Dr. F.N. Northover from $\$ 9,100$ to $\$ 9,800$ per annum and for Mr. S. Szick, Machinist, from $\$ 283.00$ per month to $\$ 3,750$ per year. Szick was one of the two technical staff laid off in 1975 . CU, Minutes of the $129^{\text {th }}$ Meeting of the BOG, September 5, 1960, 4, FN 1, Chapter 1.

${ }^{121} \mathrm{D}$. McEown, oral history. 
Until the early 1970s, this information would actually be recorded in the minutes for Board of Governors' meetings and faculty who were on campus at this time recollect that there was broad acceptance for this decision making process—one over which they clearly had little or no control. ${ }^{122}$ When past Carleton president Richard Van Loon was hired personally by Dunton ${ }^{123}$ in the early 1970 s to teach political science at the university, he understood that the president decided salary levels.

When it came to negotiating salaries, there ... were no negotiations. Dunton simply announced at the spring conference how much the salary increase for that year would be ... The faculty didn't seem to mind that because although he ran the place with an iron hand ... he was also a very friendly guy and spent a lot of around the institution. ${ }^{124}$

Despite this general impression, over time faculty did challenge Dunton's authority and attempt to negotiate certain issues. Individually, for example, according to Neatby and McEown, political scientists Pauline Jewett and her colleague Frank McRae publically complained about the difference in their salaries. ${ }^{125}$ Both were hired in June of 1955, and when they compared their ranks and salaries, Jewett and McRae discovered that, despite having equivalent training and experience, Jewett had the rank of lecturer and earned an annual salary of $\$ 4,000$ whereas McRae began as an assistant professor at "\$4,700 per annum." 126 This gender bias was not unique to Carleton and in the 1960s, Canadian female faculty earned approximately $21 \%$ less than their male colleagues. ${ }^{127}$

\footnotetext{
${ }^{122}$ According to Neatby and McEown, individual professors could negotiate their starting salaries but not later increases. Neatby and McEown, Creating Carleton, 163.

${ }^{123}$ From the oral histories of faculty members, this emerges as a standard practice for Dunton. For example, Andrew Brook was also hired by Dunton. A. Brook, oral history.

${ }^{124}$ Richard Van Loon, professor and former president of Carleton University, in oral history interview with the author, April 5, 2011.

${ }^{125}$ Neatby and McEown, Creating Carleton, 49.

${ }^{126}$ Neatby and McEown, Creating Carleton, 49; CU, Minutes of the $90^{\text {th }}$ Meeting of the BOG, June 23, 1955, 1, FN 1, Chapter 1.

${ }^{127}$ The Canadian Association of University Teachers, Submission to the Royal Commission on the Status of Women, (Ottawa: Canadian Association of University Teachers, 1967), 2.
} 
Fortunately, in response to Jewett's case, McRae complained to President Gibson and Jewett was "promoted the following year." ${ }^{128}$ Collectively, over time CUASA representatives "became more vocal about salaries." 129

In the early 1960s, the association's approach was to be consultative and representatives presented a salary brief to the president each year, as did faculty associations at other Canadian universities such as the University of Toronto. ${ }^{130}$ However, in the late 1960s and early 1970s, professors were more determined in their attempts to make this process democratic — not just for reasons of principle but also to improve their standard of living. Salary levels at Carleton had persistently been uncompetitive, with some faculty actually taking "pay cuts" to work at Carleton and, amongst provincial universities, Carleton's salaries were low, especially for junior faculty (see Table 2.1 for median salaries for Canadian professors over a 35 -year period). ${ }^{131}$ In addition, as will be discussed later, in 1966 significant changes in the allocation of government funding for higher education began to introduced greater "uncertainty" into university financial matters and threatened to prevent further income gains. ${ }^{132}$

${ }^{128} \mathrm{CU}$, Minutes of the $98^{\text {th }}$ Meeting of the BOG, May 17, 1956, 2, FN 1, Chapter 1.

${ }^{129}$ Neatby and McEown, Creating Carleton, 163.

${ }^{130}$ Ibid. Nelson, Search for Faculty Power, 12.

${ }^{131}$ CUASA, Newsletter (February 1970): 1, FN 1, Chapter 2. For example, D. Coll, oral history; and Joseph Scanlon, retired professor, Carleton University, in oral history interview with the author, May 25, 2011.

${ }^{132} \mathrm{CU}$, Minutes of the $184^{\text {th }}$ Meeting of the BOG, April 12, 1967, 2, FN 1, Chapter 1. 
Table 2.1 Median Salaries for Full-time Faculty (Selected Years 1937-1971) Canada $^{133}$

\begin{tabular}{lc}
\hline Year & Median Salary \\
\hline $\mathbf{1 9 3 7 - 3 8}$ & $\$ 3,211$ \\
$\mathbf{1 9 3 9 - 4 0}$ & 3,161 \\
$\mathbf{1 9 4 2 - 4 3}$ & 3,253 \\
$\mathbf{1 9 5 0 - 5 1}$ & 4,797 \\
$\mathbf{1 9 5 6 - 5 7}$ & 5,892 \\
$\mathbf{1 9 5 9 - 6 0}$ & 7,979 \\
$\mathbf{1 9 6 1 - 6 2}$ & 8,402 \\
$\mathbf{1 9 7 1 - 7 2}$ & 13,265 \\
\hline
\end{tabular}

Table reproduced from Jill Vickers and June Adam, but can you type? Original source data: DBS Publication 81-203. Salaries and Qualifications of Teachers in Universities and Colleges for the Various Years.

By December of 1970, the tone of CUASA's position on salary levels was decidedly more assertive than it had been in the 1960s. Likewise, a report in the CUASA newsletter referred to the salary proposals presented to President Dunton by the association's "negotiating group" and an "agreement" to regarding individual salary increases. ${ }^{134}$ The following year, the CUASA salary committee made a counter proposal to Dunton, arguing that he revise the original annual salary increase for "continuing faculty" above the percentage he had originally "offered" and then they held a secret ballot so that faculty could vote on the proposed increase — the first time this strategy had been used to communicate with the general membership on proposed salary increases. ${ }^{135}$ CUASA representatives were not using collective bargaining at this point, but such efforts to participate in decision-making could be interpreted as early and informal

\footnotetext{
${ }^{133}$ Vickers and Adams, but can you type?, 114.

${ }^{134}$ Carleton University Academic Staff Association, Newsletter 1, no. 4 (December 1970), FN 1, Chapter 2.

${ }^{135}$ Carleton University Academic Staff Association, Newsletter "Salary Special," 1, no. 5 (February 1971): 1-3, FN 1, Chapter 2.
} 
attempts to gain "voluntary recognition" for CUASA as the academic staff's negotiating representative. The issue of salary levels was not the only employment-related topic that reflected a concern amongst faculty about the nature of decision making on campus. Whereas the president kept tight control over salary decisions, faculty found that there was a decided lack of formal policies and procedures for the key areas of tenure and promotions. For example, Naomi Griffiths noticed that "teaching evaluation ... was a much more sloppy process until unionization" and Blair Neatby believes that the granting of promotions was equally vague because "Dunton would ... name people as full professors, people who he thought deserved it. His judgment was fairly good ... but there was no structure." 136 With regard to tenure, Neatby viewed this as an "inevitable privilege, ${ }^{, 137}$ which might in part explain why Andrew Brooks' impression, based on his own experience, was that there was no visible process for granting of tenure.

Carleton was a place of massive informality and actually very low standards when I arrived. My consideration for tenure consisted in passing the head of the department ... in the hallway, him turning around and saying, "Oh, by the way, Andy, you've got tenure" ... I had no idea I was even being considered and at that point I think I had one publication out, it was a fairly substantial one, and ... more in the pipeline. That wouldn't even get you on the long short list for a hire anymore, let alone get you hired and tenured. ${ }^{138}$

Tenure policies and procedures had been under discussion at Carleton since 1960 when CUASA representatives first approached the board to produce written procedures. After persistent and repeated efforts on the part of faculty to convince President Dunton and the

\footnotetext{
${ }^{136}$ N. Griffiths, oral history; B. Neatby, oral history.

${ }_{138}^{137}$ Neatby and McEown, Creating Carleton, 164.

${ }^{138}$ Ibid.; A. Brook, oral history.
} 
board to produce a formal policy, the Board finally approved an official document on June $27,1972 .^{139}$

According to Neatby and McEown, Carleton professors were not militant in their relationship with President Dunton and other senior administrators, even in the early 1970s when faculty were clearly attempting to negotiate salaries. ${ }^{140}$ The absence of conflict was undoubtedly due, in part, to Dunton's success as a "Janus-like" manager who could adroitly respond to and mediate the needs of both faculty and board members. ${ }^{141}$ However, the peaceful relations on campus could also have been facilitated by a continuing commitment to collegiality on the part of faculty as well as changes in university governance that made the academic workplace more compatible with this ideal of the "scholarly community" during the 1960s. In particular, some modifications were made in the composition of the Senate and the Board.

In 1960, the governors passed a motion that permitted members of the faculty board to nominate three professors to the Senate because, as President Dunton reported, senators were "taking a more active role in the academic work of the University, and to properly carry out these increasing responsibilities it needed to be more representative.” ${ }^{\prime 12}$ By 1963, senior professors were being joined at Senate by their junior colleagues, i.e., those at the associate and assistant levels. ${ }^{143}$ Then, in 1968 in the wake of the CAUT-AUCC sponsored commission on university governance chaired by Sir James Duff and Robert Berdahl, President Dunton reported to the Board that both CUASA and

${ }^{139}$ Neatby and McEown, Creating Carleton, 164; CU, Minutes of the $238^{\text {th }}$ Meeting of the BOG, June 27, 1972), 4-7, FN 1, Chapter 1.

${ }^{140}$ For example, see CUASA Newsletter, 1, no. 4 (December 1970), FN 1, Chapter 2.

${ }^{141} \mathrm{~N}$. Griffiths, oral history.

${ }^{142} \mathrm{CU}$, Minutes of the $125^{\text {th }}$ Meeting of the BOG, February 4, 1960, 2, FN 1, Chapter 1.

${ }^{143} \mathrm{CU}$, Minutes of the $148^{\text {th }}$ Meeting of the BOG, May 16, 1963, 5, FN 1, Chapter 1 . That year Hilda Gifford, the chief librarian, was appointed to Senate for a three-year term. 
the Senate were prepared to establish a joint committee to study university government at Carleton. ${ }^{144}$ The joint committee submitted its draft report to the Board in June 1967 and, after receiving comments from separate Board and Senate committees over the next year, the board approved in principle the joint committee's recommendations on June 26, 1968. ${ }^{145}$ The major changes to university government were intended to "improve communications" between faculty, students, the "governing bodies" and senior administrators and, as a result, the Board would now include three elected senators while the various faculty boards would be responsible for the election of half the senators; three seats on Senate would be reserved for representatives of the board. ${ }^{146}$

While faculty undoubtedly welcomed greater representation in institutional decision-making, these modifications were modest and not radical enough to shift the balance of power within the university. The Board retained legal control over decisionmaking at Carleton and the number of academic governors was still small relative to the other membership. ${ }^{147}$ The process of electing faculty to the Senate and the Board was a positive - and sought-after-development but nonetheless, the university remained more of a bureaucracy than a scholarly community. A greater number of professors involved in these two bodies still would not allow faculty to "dominate" the university and ultimately did not prove to be a bulwark against discontent or unionization.

The years between 1968 and 1972 were ones of widespread activism that influenced professors across the country. Various groups across North America were

${ }^{144} \mathrm{CU}$, Minutes of the $172^{\text {nd }}$ Meeting of the BOG, January 27, 1966), 4, FN 1, Chapter 1 . The DuffBerdahl commission was co-sponsored by CAUT and the Association of Universities and Colleges of Canada. For further discussion, see Chapter 1 of this thesis.

${ }^{145} \mathrm{CU}$, Minutes of the 199th Meeting of the BOG, June 26, 1968, 5-6, FN 1, Chapter 1.

${ }^{146} \mathrm{CU}$, Minutes of the $199^{\text {th }}$ Meeting of the BOG, June 26, 1968, FN 1; Chapter 1; Neatby and McEown, Creating Carleton, 152-54.

${ }^{147}$ Neatby and McEown, Creating Carleton, 149. 
mobilizing in order to gain greater political and social rights, including white-collar workers who were employed in non-manual jobs in both the public and private sectors. In Canada, the number of unionized employees grew by 57\% from 1957 to 1970 and the number of "public administration" unionized workers grew from $24.9 \%$ in 1962 to $74.3 \%$ in $1970 .{ }^{148}$ This trend was evident not only amongst clerical and administrative workers but also those who identified themselves as professional employees. ${ }^{149}$ For example, members of the Professional Institute of the Public Service of Canada (PIPSC) considered themselves to be "high skilled" professional employees and worked in civil service groups such as engineering and land survey, historical research and mathematics that could be engaged in work similar to that of academics. ${ }^{150}$ Like faculty members, they had long-standing concerns about employment conditions similar such as salaries as well as their relationship with government administrators. Despite years of internal debate as to the appropriateness of collective bargaining for professionals who traditionally consulted with managers, in 1967 the PIPSC became the bargaining agent for many of its member professional occupational units. ${ }^{151}$

Academics were not untouched by this growing interest in collective bargaining amongst white-collar employees. Members of CAUT recognized that these reforms were limited and, particularly given the lack of written processes for tenure and dismissal, that

${ }^{148}$ J.K. Eaton, Union Growth in Canada in the Sixties, Labour Canada, Economics and Research Branch, (Ottawa: Information Canada, 1976): 11 and 53. Eaton does not define public administration clearly, although he indicates that these unionized workers belonged to the unions and government employees' associations.

${ }^{149}$ Bain, The Growth of White-Collar Unionism (Oxford, Clarendon Press, 1970). See also, for example, Archie Kleingartner, "The Organization of White-Collar Workers," British Journal of Industrial Relations 6, no. 1 (March 1968): 79-93; and Everett M. Kassalow, "Canadian and U.S. White-Collar Union Increases," Monthly Labor Review (July 1968): 45.

${ }^{150}$ John Swettenham and David Kealy, Serving the State: A History of the Professional Institute of The Public Service of Canada 1920-1970 (Ottawa: Le Droit, 1970), 247.

${ }^{151}$ Ibid., 159. 
faculty were still vulnerable to the potentially arbitrary power of boards and senior administrators. ${ }^{152}$ Faced with a lack of protection for what were considered core employment conditions, professors increasingly considered bargaining as a viable option for faculty on Canadian campuses. Nationally, CAUT formed a bargaining committee in 1971 and a section of the CAUT Bulletin was devoted to articles on collective bargaining in late $1972 .{ }^{153}$ In addition to the growth in the labour movement, the women's movement in Canada was also beginning to have an impact at universities. Canadian women were becoming more politicized and vocal in their demands for an improvement in their status as citizens, demands that were heard in a variety of spaces including the Royal Commission on the Status of Women in $1968 .{ }^{154}$ While the majority of faculty members at this time were men, more and more women were pursuing graduate studies and entering academia and many of these women embraced the ideas of "second wave feminism," particularly that of "equal pay for work of equal value."155

Despite the evidence of growing social discontent in Canada, at Carleton, apparently faculty continued to have a relatively non-confrontational relationship with senior university administrators even as they persistently sought improvements in their terms and conditions of work over the next four years. This period was increasingly challenging as changes to government policy, once again, led to a reduction in funding

${ }^{152}$ CAUT had an active Committee on Academic Freedom and Tenure. The committee regularly published reports in the C.A.U.T Bulletin in the early 1970s and conducted a survey of member institutions on tenure in 1971.

153 “Collective Bargaining Symposium, C.A.U.T. Bulletin (Winter 1972): 39-59.

${ }^{154}$ Joan Sangster, "Radical Ruptures: Feminism, Labor and the Left in the Long Sixties in Canada," American Review of Canadian Studies 40, no. 1 (March 2010): 1.

${ }^{155}$ J. Vickers, oral history. See Judy Rebick, Ten Thousand Roses: The Making of a Feminist Revolution (Toronto: Penguin Canada, 2005) for an overview of the Canadian women's movement in this period. 
for post-secondary education and the cost-of-living in Canada began to rise. ${ }^{156}$ A pivotal change took place in 1972 that precipitated the end of these peaceful relations. Davidson Dunton resigned after serving the university as president for fourteen years, a decision that Don McEown describes as a "great disappointment to all of us." ${ }^{157}$ Michael Kelway Oliver succeeded Dunton as president and it is his leadership that ultimately triggered the decision by faculty to take the momentous step of unionizing. In fact, Jill Vickers herself still believes that if "Davy" had still been the president in 1975, the faculty might not have been tempted to unionize — at least not at that point in time. ${ }^{158}$

\section{Going from Association to Union: "Michael Made Some Mistakes”}

If Michael K. Oliver was optimistic or confident about becoming Carleton University's sixth president in June 1972, his feelings would have been easy to justify. Naturally, he might have anticipated challenges because, as his friend Blair Neatby points out, "the new, incoming president doesn't know how to do things the way they were, and doesn't often know who to consult" ${ }^{\text {159 }}$ However, Oliver would have balanced any concerns he had about his new job against the fact that he was going to be working in the type of institution he presumably knew relatively well: a Canadian university. He had spent his academic career-first as a student, then as a professor and vice-principal (academic) — in Montreal at McGill University. ${ }^{160}$ McGill had a governance structure similar to Carleton's and the university community had also faced significant financial

${ }^{156}$ Neatby and McEown, Creating Carleton, 187.

${ }^{157}$ D. McEown, oral history.

${ }^{158} \mathrm{~J}$. Vickers, oral history.

${ }^{159}$ B. Neatby, oral history. See also, Oliver, This Week Times Two 4, no. 1 (Thursday, September 14, 1972): 1, FN 3, Chapter 2.

${ }^{160}$ Alan Husak, "First NDP President a 'Boundless Optimist'," The Ottawa Citizen, October 2, 2004: E3, accessed November 25, 2013, http://search.proquest.com.proxy.library.carleton.ca/docview/240780699/1420087AF5B351C248A/1?acco untid $=9894$. 
and organizational issues brought on by the "boom and bust" in postsecondary education of the 1960s and 1970s. ${ }^{161}$ Oliver had even recently chaired a key institutional committee that successfully helped to secure McGill's "financial future" at a time when the Quebec government was threatening to cut its grants to the university. ${ }^{162}$ In addition, he had been the inaugural president of Canada's pro-labour New Democratic Party and as a "leftie" might very well have assumed he would enjoy at least civil if not cooperative relations with Carleton's various employee groups. ${ }^{163}$ Whatever he felt as he began his presidency, however, he must have been dismayed at how little time it took for him to disappoint many of his Carleton colleagues.

Oliver "made some mistakes" and became very unpopular very quickly. ${ }^{164}$ Remembered by some as a "clumsy," "threatening" 165 leader, he seemed the antithesis of the charming, friendly Dunton and within the first two years of his mandate, professors, librarians and support staff were all, to varying degrees, distrustful and worried about layoffs while generally questioning the fairness of the policies and procedures related to their terms and conditions of work. ${ }^{166}$ However, the differences between the two men were not simply a question of personality or style. Oliver inherited a set of issues from his predecessor that he had to tackle with one distinct disadvantage: "Dunton was a president in good times when there was lots of cash. Oliver was a president in bad times. ${ }^{\not 67}$ Dunton had gained trust and goodwill during an unparalleled period of growth whereas Oliver had to build relationships when the university community was grappling

${ }^{161}$ Stanley Brice Frost, McGill University: For the Advancement of Learning, II, 1895-1971

(Kingston and Montreal: McGill-Queen's University Press, 1984). In particular, see Part III, Chapter 14.

${ }^{162}$ Ibid., 426.

${ }^{163} \mathrm{~J}$. Vickers, oral history.

${ }^{164}$ B. Neatby, oral history.

165 J. Vickers, oral history.

${ }^{166} \mathrm{D}$. McEown oral history.

${ }^{167}$ J. Vickers, oral history. 
with possible retrenchments and a "looming financial crisis"- not an enviable

position. ${ }^{168}$ Unfortunately, many faculty were alienated by his attempts to make "difficult decisions ... as wisely as possible," including key CUASA officers such as Jill Vickers. ${ }^{169}$

Oliver proposed two changes in the first month of his tenure at Carleton that are remembered as contributing significantly to a creating a sense of unease and distrust amongst professors: one, the creation of the new office of vice-president and two, the modification of the existing budgeting process. ${ }^{170}$ After receiving the official welcome from Board members at his first governors' meeting on October 4, 1972, he promptly recommended the appointment of two vice-presidents to oversee academic matters and university administration. ${ }^{171} \mathrm{He}$ argued that these positions would benefit the university as he would have the help he needed to meet the "larger demands" he faced "within the framework of the present circumstances." ${ }^{172}$ The new officials would share responsibility for "university-wide" matters, rather than centralizing control and work in the president's office. ${ }^{173}$ In addition, they would apply their skills and knowledge of Carleton's operations to the "greater academic and financial planning" which the university would have to undertake in the future and would represent Carleton in its relations with other universities and the provincial government. ${ }^{174}$

${ }^{168}$ A. Brook, oral history.

169 "President Oliver's Statement," This Week Times Two 4, no. 1 (Thursday, September 14, 1972), FN 3, Chapter 2; J. Vickers, oral history.

${ }^{170} \mathrm{~A}$. Brook, oral history; J. Vickers, oral history, D. McEown, oral history.

${ }^{171} \mathrm{CU}$, Minutes of the $239^{\text {th }}$ Meeting of the BOG, October 4, 1972, 2-3 FN 1, Chapter 1.

${ }^{172}$ Ibid.

${ }^{173}$ Ibid.

${ }^{174}$ Ibid. 
In addition to asking for two new senior managers, Oliver also had to report "[that] as a result of the shortfall in enrolment the financial picture was less than rosy." His solutions to the university's economic challenges included cutting institutional costs and introducing stronger planning processes. In particular, he supported the establishment of a joint budget review committee, which had already been discussed by the Senate. ${ }^{176}$ Members of both the Board and the Senate would sit on the committee and the coordinated input from both decision-making groups would allow the university to do "the necessary work which will have to be done to bring about substitution of programmes for change which contrasts to the situation which existed previously in which change could always be achieved within the cushion of growth." 177

These proposals were not necessarily obvious triggers for what has been described as a "very unhappy time in the life of the university." 178 Although Dunton had not had any vice-presidential positions, faculty had recognized that he had senior administrators effectively doing work at that level and, in retrospect, view Dunton's approach as wrong. Naomi Griffiths contends that it resulted in a lack of institutional structure that was "absolutely catastrophic" for Oliver ${ }^{179}$ while Jill Vickers concedes that

The provincial government was demanding accountability for every cent. I've been an associate vice president, I've been in that situation in which the money isn't coming, the government is forcing you to do more and more reporting of all kinds of things and you can't do that without vice presidents. You can't do that the way Dunton did it. ${ }^{180}$

\footnotetext{
${ }^{175} \mathrm{CU}$, Minutes of the $239^{\text {th }}$ Meeting of the BOG, October 4, 1972, 5, FN 1, Chapter 1.

176 "President Oliver's Statement."

${ }^{177}$ Ibid.

${ }^{178}$ D. McEown, oral history.

${ }^{179}$ N. Griffiths, oral history.

${ }^{180}$ J. Vickers, oral history.
} 
Both appointments were made relatively quickly with long-time Carleton employees being chosen to fill the positions. A.B. Larose, who had been with the university as a financial officer as well as a sessional lecturer since 1957, became the Vice-President Administration and Bursar on December 21, $1972 .{ }^{181}$ Three months later, Oliver announced that Dr. G. Ross Love had been chosen to be Carleton's new Vice-President Academic. ${ }^{182}$ Love had been a faculty member in Carleton's physics department since 1948 and had chaired the university's building advisory committee for some time. To choose the vice-president of administration, McEown describes a rather informal method of selection involving Dr. J. L. (Lorne) Gray, the chair of the Board of Governors.

Lorne Gray came into the meeting and he says "Is there any reason why we wouldn't appoint Abe?" and everybody says "No" and he says, "Let's do it" and then that was that ... it took a little longer to organize it through Ross ... since nobody knew how to do search committees and so on. ${ }^{183}$

Nonetheless many professors knew both Larose and Love and apparently the selection committee "didn't go outside, they just picked the two guys at home because they didn't know what this wild and new president was going to do. So they pick two old boys to make sure that he didn't rock the boat." ${ }^{, 184}$ In addition, as the president argued publicly, the vice presidents would make him more accessible to faculty as he could allocate less time to administration and more to working directly with "academic staff." 185

Administrators and faculty at Carleton were very familiar with the operational problems caused by a lack of adequate financial resources and an open budget review

\footnotetext{
181 “A.B. Larose Names V.P. Administration,” This Week Times Two 5, no. 1 (Tuesday, January 9, 1973), FN 3, Chapter 2.

182 "Love VP (Academic)," This Week Times Two 5, 20 (March 23, 1973), FN 3, Chapter 2: 1. Love was appointed to his new position on March 22, 1973.

${ }^{183}$ D. McEown, oral history. CU, Minutes of the $241^{\text {st }}$ Meeting of the BOG, November 29, 1972), 1 , FN 1, Chapter 1.

${ }^{184} \mathrm{D}$. McEown, oral history.

185 "Love VP (Academic)," This Week Times Two 5, 20 (Friday, March 23, 1973): 1, FN 3, Chapter 2.
} 
process could potentially provide new opportunities for faculty input. Successive college board members, presidents and senators had had to manage under severe financial constraints in the 1940s and 50s and although Dunton's first term was marked by a generous inflow of funding from both provincial and federal governments, his second term was characterized by renewed fiscal hardship. ${ }^{186}$ In 1966 , the federal government announced that it would no longer provide universities with direct per capita operating funding or grants for a variety of capital projects. ${ }^{187}$ Instead, additional federal tax revenue would be transferred to the provincial governments, which in turn would disburse operating and other grants. ${ }^{188}$ Dunton continually alerted the Board throughout the year that, as a result of this change in federal policy, the province would introduce a new method for allocating funding and in March 1967, the Ontario government officially announced that future operating grants would be calculated based on enrolment as well as the weighted value of academic programs. ${ }^{189}$ Less than a year later, the province implemented a similar system for determining capital grants to cover "essential construction."

${ }^{186}$ For example on May 27 1975, he reported to the Board of Governors that in a meeting with then Deputy Minister of University Affairs McCarthy that the provincial government would not be providing all the funds necessary to complete current construction projects. $\mathrm{CU}$, Minutes of the $166^{\text {th }}$ Meeting of the BOG, May 27, 1975, 3, FN 1, Chapter 1.

${ }^{187}$ Cameron, More Than an Academic Question, 130-31.

${ }^{188}$ Ibid.

${ }^{189}$ Dunton did not elaborate further on the funding formula at this meeting. However, as David Cameron states in his study of universities and Canadian government policy, the "weighted enrolment, or the number of "basic income units" credited to each university, was simply the actual number of students on December 1 of the year in question, multiplied by weighting factors applicable to specific programs ... [which were] based on approximate average costs per student derived from a study within the University of Toronto ... and each program was assigned a weight." In addition, the government calculated an annual per student value that was multiplied by the weighted enrolment at each institution. Apparently this formula system was adopted by other provincial governments in English Canada. Cameron, More Than an Academic Question, 163.

${ }^{190} \mathrm{CU}$, Minutes of the $194^{\text {th }}$ Meeting of the BOG, January 17,1968 , 2, FN 1, Chapter 1. 
While Dunton initially indicated that this formula approach to operating grants could be a "reasonably fair way of dividing money amongst universities" 191 that might benefit Carleton, he did warn the board that it could also introduce income "uncertainties"192 and over time it became clear that universities were now operating in the era of "more scholar for the dollar." 193 Partially in response to a shift in public opinion that devalued the role of higher education in economic development, the Ontario government began to reduce its support for universities. ${ }^{194}$ Dunton summarized the government's philosophy regarding these changes to the Carleton Board in December 1970. As he explained, at a recent meeting between members of the Committee of Presidents of Universities of Ontario and the Minister of University Affairs,

the Minister had outlined some of the government's concerns with the present development of the universities of Ontario. The most significant of these was the continual problem of financing and the government felt it was still possible and desirable that places be found for all qualified students without the rate of growth of expenditure matching the rate of growth of enrolment because it should be possible for the universities to more effectively utilize their resources. It was reported that the Minister also expressed concern about such specific matters as the rate of growth of graduate programmes. ${ }^{195}$

The discussions at Carleton Board meetings between 1969 and 1972 might very well have reflected the concerns at other Ontario universities during this period as well as those at English Canadian institutions in other provinces where similar systems of funding had been or were being adopted. ${ }^{196}$ Now that the value of operating grants was determined by an enrolment-based formula, the president began to report regularly on registration figures. In 1969 and early 1970, the news was essentially positive as

\footnotetext{
${ }^{191} \mathrm{CU}$, Minutes of the $183^{\text {rd }}$ Meeting of the BOG, March 9, 1967, 5, FN 1, Chapter 1.

${ }^{192} \mathrm{CU}$, Minutes of the $184^{\text {th }}$ Meeting of the BOG, April 12, 1967, 2, FN 1, Chapter 1.

${ }_{193}$ Axelrod, Scholars and Dollars, 149.

${ }^{194}$ Ibid.

${ }^{195} \mathrm{CU}$, Minutes of the $223^{\text {th }}$ Meeting of the BOG, December 22, 1970, 3, FN 1, Chapter 1.

${ }^{196}$ Cameron, More than an Academic Question, 161-62. According to Cameron, Ontario's model was adopted across the country.
} 
generally enrolment was increasing. ${ }^{197}$ However, by October 1970, Dunton had to report that in fact enrolment was fluctuating and "there was a new magnitude of problems; that Carleton was a different place from the Carleton of two years ago." 198 The institutional difference was not due to registration rates alone, but also to the fact that the provincial unit value-i.e., the base cost per student value determined by the provincial government each year-was expected to increase by only $4.8 \%$ and this additional funding would not be enough to cover inflation. ${ }^{199}$

Dunton continued to be cautious over the next two years as, despite another rise in enrolment, "the rate of increase was decreasing" 200 and changes to the unit value were small. ${ }^{201}$ Little comfort came from the knowledge that enrolment trends were similar across the province, ${ }^{202}$ particularly as another threat emerged that year when the province began to consider cutting its support for graduate programs in further efforts to reduce spending on post-secondary education. These cuts included a $30 \%$ decrease in graduate fellowships and no funding for graduate students enrolled in new programs. ${ }^{203}$ Dunton predicted that such changes could result in fewer graduate students and a potential loss of revenue to Carleton of between $\$ 500,000$ and $\$ 750,000$ in $1972 .{ }^{204}$ By the end of that

${ }^{197}$ For example, on October 29, 1969 he stated that the total number of full-time students was up by "just under 20\%." CU, Minutes of the $211^{\text {th }}$ Meeting of the BOG, October 20, 1969, 7, FN 1, Chapter 1.; Axelrod, Scholars and Dollars, 141.

${ }^{198} \mathrm{CU}$, Minutes of the $221^{\text {st }}$ Meeting of the BOG, October 22, 1970, 6, FN 1, Chapter 1.

${ }^{199}$ Ibid.

${ }^{200} \mathrm{CU}$, Minutes of the $222^{\text {nd }}$ Meeting of the BOG, November 30, 1970, 2, FN 1, Chapter 1.

${ }^{201}$ For example, in 1971 the government announced that the unit value for the 1972-1973 academic year would only increase by $2 \%$. CU, Minutes of the $227^{\text {th }}$ Meeting of the BOG, May 31, 1971, 2, FN 1 , Chapter 1.

${ }^{202} \mathrm{CU}$, Minutes of the $230^{\text {th }}$ Meeting of the BOG, October 26, 1971, 2, FN 1, Chapter 1.

${ }^{203} \mathrm{CU}$, Minutes of the $224^{\text {th }}$ Meeting of the BOG, January $25,1971,2$, FN 1, Chapter 1.

${ }^{204}$ Ibid., 3 . 
year, he had initiated a budget review to reduce expenditures in order to make budget cuts. $^{205}$

Throughout this period, the president publicly objected to the weighting system, particularly for operating grants, in an attempt to pressure the government into modifying the funding formula. ${ }^{206}$ While in theory such an allocation method might be more objective than the previous "deficit" funding, ${ }^{207}$ in reality, Dunton believed that it led to inequitable allocations for Carleton primarily because the formula led to underweighting for some of the university's undergraduate programs as well as its large enrolment of part-time students. ${ }^{208}$ The provincial government was "sympathetic" to Carleton's situation but would not change any factors in the formula. ${ }^{209}$ It embarked instead on a reexamination of public policy. Dunton thought that this exercise had "the potential to initiate profound changes to post-secondary education in Ontario,",210 that could relate tie funding to "the subjective judgment of a body in Toronto about the research output," and increase tuition fees. ${ }^{211}$ The government had clearly been determined to force a "pause in growth" ${ }^{212}$ for some time, and Dunton had been open with the Board about the university's fiscal vulnerability since the introduction of formula funding in 1967. Oliver

${ }^{205} \mathrm{CU}$, Minutes of $231^{\text {st }}$ Meeting of the BOG, November 24, 1971, 4, FN 1, Chapter 1.

${ }^{206}$ Dunton belonged to the Council of Presidents, which regularly made submissions to the Committee on University Affairs, the advisory committee that reported to the Minister of Education.

${ }^{207}$ Cameron, More Than an Academic Question, 161.

${ }^{208} \mathrm{CU}$, Minutes of the $223^{\text {rd }}$ Meeting of the BOG, 2, FN 1, Chapter 1.

${ }^{209}$ Ibid.

${ }^{210}$ Ibid. In his final presidential report, released in October 1972, Dunton argued that although declining enrolment could benefit universities because they would be admitting "a lower proportion of students whose prime interest is in having some sort of degree to record on a job application." He also stated that the COPSE draft report (Learning Society: Report of the Commission on Post-Secondary Education in Ontario) included recommendations that could threaten universities. In particularly, the proposal that "future government grants be divided into two categories: one for educational expenditures and one for research"- an impossible task in his opinion. "President's Report Released," This Week Times Two 4, no. 9 (October 20, 1972), FN 3, Chapter 2.

${ }^{211}$ Ibid.

212 "President Oliver's Statement," FN 3, Chapter 2. 
might have expected that professors would welcome an open budget review that included participation from Senate members, particularly as an inclusive process might have seemed compatible with the commitment of faculty to participatory university government. ${ }^{213}$ However, over the next two years, academic staff suffered a steady "loss of trust in the management." 214

This growing mistrust reflected the strain resulting from Carleton's currently "bleak" financial reality that contrasted so starkly with the optimism of the earlier period of expansion. Although he had only been at the university since 1969, Andrew Brook understood that the institution was facing years of considerable operational contraction after a period of exponential growth:

We'd gone from the solid days of the late 60 s when this place doubled in size, trebled in size I think in less than a decade, to a period in which all capital expenditures had been frozen and there was talk about universities had overexpanded and ... there should be cut backs. ${ }^{215}$

He was concerned not just about potential budget cuts but also about the ability of the president to fulfil one of his primary roles of effectively defending the university's interests in front of the Ontario government, something, Brook believed, Dunton was better at than Oliver. ${ }^{216}$ Other faculty members shared these fears, despite the fact that Oliver had taken up Dunton's torch and expended considerable energy in advocacy on behalf of Carleton with representatives of the Ministry of Colleges and Universities and the Committee of University Affairs (CUA). ${ }^{217}$

${ }^{213}$ Ibid.

${ }^{214}$ D. McEown, oral history.

${ }^{215}$ A. Brook, oral history.

${ }^{216}$ Ibid.

${ }^{217}$ For example, "Board of Governors," This Week Times Two 6, no. 9 (Thursday, June 7, 1973): 1, FN 3, Chapter 2. 
Between 1972 and 1974, Oliver regularly attended the meetings of the Council of Ontario Universities (COU), the association of Ontario university presidents, and supported all its attempts to pressure the provincial government into changing the operating funding formula. He publicly argued that it did not treat Carleton "fairly," given that the proportion of the University's income coming from the government was "one of the lowest ... in the province." ${ }^{218}$ As he stated at a General Faculty Board meeting in early May 1973, “it's a ridiculous proposition that this University should find itself among the first—let alone being the first — to use the internal planning mechanisms ... to adjust to a situation which has basic elements of inequity in it." ${ }^{219}$ Oliver also headed the university's delegation to the annual meetings with the CUA, as well as special meetings with the minister. Other senior administrators were also active provincially; example, the Vice-President (Administration) A.B. Larose, for instance, became the "the first university administrator" to advise the ministry on strategies for the funding formula. ${ }^{220}$

Ironically, the professors' lack of confidence in Oliver's ability to protect the university might have been encouraged by his attempts to make the university's financial planning process more inclusive. Don McEown, who had a ringside seat in the arena of university decision-making as the secretary to the Board of Governors at this time, thinks that Oliver's "decision to do much of the budget in public" contributed to a perception that the president was inconsistent because it effectively put those involved onto a "financial crisis" rollercoaster.

2.

218 “General Faculty Board,” This Week Times Two 6, no. 5 (Thursday, May 10, 1973), FN 3, Chapter

\footnotetext{
${ }^{219}$ Ibid. Oliver was referring to the university's budgeting and academic planning processes as "internal planning mechanisms."

${ }^{220} \mathrm{CU}$, Minutes of the $249^{\text {th }}$ Meeting of the BOG, September 24, 1973, 5, FN 1, Chapter 1.
} 
He [Oliver] was quite prepared to describe how much he was going to allocate for faculty salaries in general and staff salaries and whatever else and how it was going to be worked ... but the problem was that the estimates of revenue that were being produced at the time always show huge deficits and then the other thing that happens is that the forecasts that people make don't come to pass. ${ }^{221}$

In each of the first two years of his presidency, Oliver (or Vice-President A.B. Larose) would announce a possible deficit that must have seemed astronomical to the community only to later report that the financial situation was better than anticipated. For example, in September 1972 the potential shortfall was forecast to be as high as $\$ 1.3$ million and eight months later, Larose stated that the deficit might actually be as low as $\$ 250,000$ to $\$ 300,000 .{ }^{222}$ In addition, non-academic departments such as the library and physical plant were known to be busy reviewing their budgets to identify areas where expenditures could be cut, including staff reductions. ${ }^{223}$ As a result, professors had significant access to financial information about the university's operations and, in the process, Oliver became widely disliked and was "blamed for a lot of things." ${ }^{224}$ Neatby thinks that some of this dislike stemmed from the faculty's belief that Oliver was actually concealing rather than revealing vital information.

It was widely felt, by professors, that Michael wasn't telling them everything that they needed to know ... he would talk about how hard up the institution was, and you couldn't raise salaries and that kind of thing. And then it would emerge that there was kind of a million dollars cached away or something, or so on. So ... it was widely thought that Michael had hidden objectives. They didn't know what he wanted and they were suspicious because he wasn't being open. ${ }^{225}$

${ }^{221}$ D. McEown, oral history.

222 "President's Statement”; "General Faculty Board, “This Week Times Two, 6, no. 5 (May 10, 1973), FN 3, Chapter 2.

223 "Library Committee Tackles Budget," This Week Times Two 5, no. 16 (Friday, March 9, 1973), FN 3, Chapter 2; "Operation Save," This Week Times Two, 5, no. 19 (Tuesday, March 20, 1973), FN 3, Chapter 2.

${ }^{224}$ B. Neatby, oral history.

${ }^{225}$ Ibid. Given his friendship with Oliver, Neatby did not discuss the president's performance with his colleagues. 
In particular, they became increasingly suspicious that their jobs might be in jeopardy. Now that professors were expected to engage in academic and financial planning, they had to consider the possibility of cuts to academic staff when there were no approved rules or regulations for laying off faculty at times of financial crisis- "the spectre of redundancy, like Banquo's ghost" was a constant disturbance. ${ }^{226}$ In October 1972, just weeks after Oliver arrived on campus, the board had approved Carleton's first official "Tenure and Dismissal document" which outlined the policies and procedures that governed the dismissal of tenured faculty. ${ }^{227}$ However, this document did not outline the process for academic layoffs for budgetary reasons and, as Professor Joe Scanlon emphasized at a Senate meeting in April 1973, "tenure ... only protected against dismissal without cause and guaranteed the right of appeal"; it was not "a guarantee of permanent employment. ${ }^{228}$ Work on the Redundancy Report continued throughout 1973 and 1974, with some progress being made towards a reaching agreement on a set of redundancy regulations. In particular, there seemed to be consensus on the principle that academic staff layoffs would only be considered as a "last resort" when all possible cuts had been made to other expenses such as maintenance expenditures. ${ }^{229}$

By 1974, however, the Board was delaying approval of what had become the Draft Document on Procedures for the Release of Teaching Staff in Times of Financial Stringency due to a difference of opinion as to whether the Senate or the Board had the legal authority to declare a financial crisis. In addition, faculty members like Bela Egyed,

\footnotetext{
226 “General Faculty Board,” This Week Times Two, 5, no. 10 (Thursday, May 10, 1973), FN 3, Chapter 2.

227 "Board Approves Tenure and Dismissal," This Week Times Two 4, no. 6: 1 (Friday, October 6, 19720, FN 3, Chapter 2.

228 "Senate Discusses Redundancy," This Week Times Two 6, no. 3 (Thursday, April 26, 1973), FN 3 , Chapter 2.

229 “CUASA Council," This Week Times Two 10, no. 4 (October 18, 1974): 1, FN 3, Chapter 2.
} 
an assistant professor of philosophy at Saint Patrick's College, eventually withdrew their support for the policy because they "had seen a disturbing trend towards tension and insecurity in the academic community since the document first came into being." ${ }^{230}$ While some professors had treated the academic and budget planning processes as opportunities to avert a catastrophe with "maturity and restraint,"231 others were threatened by the possibility that tenured faculty could be declared redundant. They saw themselves as vulnerable to "a new president ... [who had] decided that 'Carleton is going to hell in a hand basket and he's going to get rid of a whole lot of us'.,232

These feelings peaked in the fall of 1974 when the president reported that "it was hard times financially and things were gonna be rough." ${ }^{233}$ While Oliver had informed the Board of Governors in late 1973 that registration figures were better than expected, thus providing "some degree of encouragement in comparison with the bleak situation which existed last year,"234 by the time he convened the annual General Faculty Board meeting on October 6, 1974, the university's fortunes again seemed to have worsened. Enrolment was essentially static and, as A.B. Larose indicated at the same meeting, while the deficits were balanced for 1974 and 1975, "the trend for $1975-76 \ldots$ is for a larger deficit. ${ }^{235}$ Given that Carleton still was the university "generating the lowest BIU's [sic]" in Ontario, Oliver believed that the university faced serious financial challenges. ${ }^{236} \mathrm{He}$

230 “Redundancy Report Before Senate," This Week Times Two 10, no. 17 (Tuesday, December 3, 1974), FN 3, Chapter 2.

231 “General Faculty Board.” FN 3, Chapter 2.

232 J. Vickers, oral history.

233 Ibid.

${ }^{234} \mathrm{CU}$, Minutes of the $250^{\text {th }}$ Meeting of the BOG, October 30, 1973, 3, FN 1, Chapter 1.

235 “General Faculty Board," This Week Times Two 10, no. 3 (Friday, October 11, 1974), FN 3, Chapter 2.

236 “General Faculty Board,” This Week Times Two (Thursday, May 10, 1973), 1, FN 3, Chapter 2. 
then laid out a strategy for Carleton's "salvation." 237 The funding formula should be changed and he hoped that by presenting a strong case based on Carleton's "short-term needs" to the newly formed Ontario Council on University Affairs, ${ }^{238}$ the required modifications would be occur. However, university administrators and faculty members still had to use current resources as efficiently as possible and should not only engage in a review of current academic programs but also consider developing new professional programs based on student demand. With the "willingness to change quickly," Oliver was confident that Carleton could weather the current "crisis." ${ }^{, 239}$ Most importantly, he did not intend to fire any staff, although undoubtedly in a "tight year" there would be little money to fund new academic positions. ${ }^{240}$

This meeting was the one that "softened up" faculty for unionization. ${ }^{241}$ While the members of CUASA council publicly supported Oliver's demand for higher rates of funding from the provincial government, privately individuals were feeling threatened by "a president who was clearly going to close departments in theory because we were bankrupt." ${ }^{242}$ Council members began to "explore certification seriously" 243 in October and at a regular meeting on November 6, those members present voted unanimously to establish a committee to study collective bargaining as well as one to examine the possibility of accepting new members, including the university's professional

\footnotetext{
${ }^{237}$ Ibid.

${ }^{238}$ The Ontario Council of University Affairs was formed in 1973 by the provincial government to "coordinate" the university sector. See Cameron, More Than an Academic Question, 193.

239 "General Faculty Board," (Friday, October 11, 1974), FN 3, Chapter 2.

${ }^{240}$ Ibid.

${ }^{241} \mathrm{~J}$. Vickers, oral history.

242 "CUASA Council," This Week Times Two 10, no. 1 (Friday, October 18, 1974): 41, FN 3, Chapter 2; J. Vickers, oral history.

${ }^{243}$ Jill Vickers, Letter to Martin Foss and Val McDougall, Thursday, October 10, 1974, 1, in the author's possession.
} 
librarians. ${ }^{244}$ Before the Council could make any progress on these issues, however, Minister of Colleges and Universities James Auld announced in mid-November that the annual operating grants to universities would be the "equivalent to a $7.4 \%$ increase in the BIU"- a percentage increase that shocked the Ontario university presidents, including Michael Oliver, because they considered it too low. ${ }^{245}$ In response to this news, Oliver called a special General Faculty Board meeting for Friday November 22 to review the implications of the minister's funding statement with academic staff. Approximately 500 individuals showed up to hear him discuss the "budget blues." ${ }^{, 24}$ As he explained, the administrative team had drafted a $\$ 40$ million budget for the 1975-1976 fiscal year and was based upon an increase in the BIU of $10 \%$. Clearly this financial plan would have to be revised and reductions would be achieved by cost cutting in a number of areas including a $\$ 400,000$ decrease in allocations to "academic staffing. ${ }^{, 247} \mathrm{He}$ announced that both the Academic Planning Committee and the Budget Review Committee would hold closed-door meetings to study the proposed $\$ 1,035$ million in total budget cuts although he predicted no "immediate terminations" in staff or changes to the planned salary increases of $18 \%$ and $10 \%$ for non-academic and academic staff respectively. ${ }^{248}$

Those in attendance were reported to have urged the president not to "accept the MCU announcement as a fait accompli" - a position Oliver clearly supported as he was already planning for a December 6 meeting with the minister to request an additional operating grant. Any further concerns expressed at the meeting were downplayed in This

244 “CUASA Examines Collective Bargaining," This Week Times Two 10, no.15 (Tuesday, November 26, 1974), FN 3, Chapter 2.

245 "GFB Meeting Called to Look at '75-'76 Financing," This Week Times Two 10, no. 13 (Tuesday, November 19, 1974): 1, FN 3, Chapter 2.

246 "Budget Blues," This Week Times Two 10, no.15 (Tuesday, November 26, 1974), FN 3, Chapter 2.

${ }^{247}$ Ibid.

${ }^{248}$ Ibid. 
Week Times Two's account. However, if the October General Faculty Board meeting had softened professors to the idea of collective bargaining, Oliver's second presentation catapulted them into action. Jill Vickers was at the meeting and, according to her, "at the end ... Dave Brown and I and ... Langford and other folks who were on the executive said, "Okay, we've got it, we'll start organizing."249 The idea of cuts to academic staffing was undoubtedly unnerving, especially as the planning sessions would not be open to faculty. Oliver further fueled professors' fears when he speculated to those assembled that the budget shortfall equalled a surplus of fifty professors. The extent to which this was intentional remains debated.

He put it in terms of a coincidence, that "We've just acquired St. Pat's [and] fifty professors at Carleton. And we have a surplus of 50 professors in this institution now. If we could get rid of fifty professors then we could balance our budget." And ... some of the very active people were from St. Pat's [and] ... they thought that that was more than a coincidence. They thought that he was threatening to fire them and Michael, maybe innocently had just sort of said, “... abstractly if you look at it, we've got fifty professors too many... people took that very seriously ... job security wasn't as solid as they had believed. ${ }^{250}$

Jill Vickers was an assistant professor of political science at St. Patrick's College in 1974 and thinks that some of her colleagues from SPC might have "hoped that unionization would somehow or another save St. Pat's." ${ }^{, 251}$ However, she believes that the generalized

${ }^{249}$ J. Vickers, oral history.

${ }^{250}$ B. Neatby, oral history.

${ }^{251}$ J. Vickers, oral history. The integration of St. Patrick's College was under discussion later that year as reported in "St. Patrick's College Facing Integration?," This Week Times Two 10, no. 17 (Tuesday, December 3, 1974): 1, FN 3, Chapter 2. Faculty members had been discussing St. Patrick's for some time and was the subject of a Senate Advisory Committee given that the college was facing problems related to a decrease in enrolment and "an over-representation of faculty in the Humanities." "SPC Faculty Board," This Week Times Two 10, no. 4: 1 (Friday, October 18, 1974), FN 3, Chapter 2. Carleton agreed to purchase the Catholic Saint Patrick's College in 1967 and certainly some of the professors involved in the union drive were attached to the college, in particular Jill Vickers and Derek Sida. 
fear of job loss across campus was a more powerful motive for faculty collective actiondefinitely her own. ${ }^{252}$

Professors now moved towards unionization at "at a hectic pace." ${ }^{, 253}$ Petitioned by fifteen members, a special meeting was held on November 29 specifically to discuss collective bargaining at Carleton. With only $20 \%$ of CUASA members in attendance, the group of approximately sixty not only approved collective bargaining in principle but also mandated a review of the association constitution that would ultimately allow CUASA to submit an application for certification to the OLRB by mandating the association to regulate "employment relations" between faculty and Carleton University. ${ }^{254}$ A fourteen-person Carleton delegation, including President Oliver and the two vice-presidents, met with the Minister of Colleges and Universities on December 6 to ask for special financing. ${ }^{255}$ However, these efforts had no impact on the determination of faculty to pursue collective bargaining. Ten days after the university delegates' meeting with the provincial minister, twenty-nine CUASA council members unanimously voted in favour of forming a collective bargaining committee that would provide educational sessions for the membership and consider further the inclusion of new members. ${ }^{256}$ January was an equally busy month. CUASA's steering committee identified the

${ }^{252}$ J. Vickers, oral history. Vickers did report in CUASA News in December that some members were worried about the integration of St. Patrick's College.

${ }^{253}$ Jill Vickers, "President's Report," CUASA News 5, no. 2: 1 -2 (December 1974), FN 1, Chapter 2.

${ }^{254}$ Motions Passed at November $29^{\text {th }}$ General Meeting," CUASA News, 5, no. 2 (Dec. 1974): 1, FN 1, Chapter 2. According to the Carleton University Data Book 1974-75, there were 608 full-time faculty working at the University. Carleton University, Carleton University, Data Book 1974-75, 48, FN 3 , Chapter 1.

255 "Carleton Asks OCUA for Special Financing," This Week Times Two 10, no. 17 (Tuesday, December 10, 1974), FN 3, Chapter 2. According to the summary that appeared at the end of this article, Carleton's position was that it was already a "low cost" institution. Salaries and operating costs were kept low, and in fact its faculty were amongst the lowest paid in the province despite the fact that Carleton had one of the highest student-teacher ratios. In addition, given the university's mix of students and programs, it generated the lowest basic income unit (BIU) in the province of the established institutions. As such, the current funding formula unfairly penalized Carleton and was taking "its toll" on faculty, staff and students.

256 “Council Summary," CUASA News 5, no. 3 (January 1975): 1, FN 1, Chapter 2. 
potential obstacles to certification with the help of Jeffrey Sacks, a lawyer associated with both CAUT and OCUFA, and the collective bargaining committee planned the two-day workshop that was the cornerstone of the association's information program. Background materials for the education sessions were provided in a special edition of the CUASA newsletter that month and more than 300 members participated in the discussions and debates on unionization held on January 30 and 31 . At a general meeting held on the second day, members authorized the steering committee to draft the constitutional amendments necessary for certification. ${ }^{257}$

Over the next month, the CUASA council got ready to "take the plunge" and submit its application to the OLRB. ${ }^{258}$ Members voted in favour of the needed constitutional amendments in a referendum held in early February and several weeks later librarians had accepted the invitation to join CUASA. By March 14, CUASA had made its submission to the OLRB, and it quickly set the certification hearing for April $1 .{ }^{259}$ The proceedings lasted two days and on April 4 it was reported in This Week Times Two that the labour relations board had deemed CUASA a trade union and that the parties had "reached agreement in private consultation on the composition of the bargaining unit."260 Only two significant issues remained to be resolved: the inclusion of departmental chairs in the bargaining unit, and the need for a secret ballot representation vote. ${ }^{261}$ Despite its "virtually invariable practice of granting outright certification" where $65 \%$ of employees

\footnotetext{
257 “Constitutional Referendum Next Week," CUASA News, Special Edition (February 5, 1975): 1, FN 1, Chapter 2.

${ }^{258}$ Ibid.

${ }^{259}$ Association of Professional Librarians of Carleton University, Thirteenth Council Meeting, Friday, March 14, 1975, in the author's possession.

260 "OLRB Decision,” This Week Times Two Special Edition (Thursday, April 10, 1975): 1, FN 1, Chapter 2. 2.

261 “Certification Hearing," This Week Times Two 11, no. 18 (Friday, April 4, 1975): 1, FN 1, Chapter
} 
in the bargaining unit belong to the applying organization, the OLRB ordered a representation vote. This decision was based on evidence that CUASA had led faculty to believe that such a vote would be held, although Vickers understands that "the labour board didn't have any choice anyway because it was the first one in the province, they weren't going to let the first one go." ${ }^{262}$ The vote took place ten days later and passed with $79.7 \%$ of those casting ballots choosing CUASA as their bargaining agent. ${ }^{263}$

The issue of the inclusion of departmental chairs in the bargaining unit took longer to resolve and in fact, as far as Jill Vickers was concerned, "the wheels grind exceeding slow!" ${ }^{264}$ In making a determination, the OLRB was setting a precedent for future applications from the university sector in Ontario, in effect testing the "unique nature of the decision-making process within a university, ${ }^{, 265}$ that is to say collegial selfgovernment. The OLRB's final conclusion was that based on the traditional perception of a university as a "community of scholars, ${ }^{266}$ professors did indeed make collective employment-related decisions, such as hiring and promotions, and thus the chairs did not have significantly more authority than their departmental colleagues. ${ }^{267}$ As such, chairs were included in the bargaining unit and CUASA officially became the bargaining agent for Carleton professors on June 26, $1975 .^{268}$

Building Consensus: "It Wasn't About Money, It Was About the 'Rule of Law'”

${ }^{262}$ J. Vickers, oral history.

263 "OLRB Decision," (Thursday, April 10, 1975), 1, FN 1, CHAPTER 2; "Majority Votes Yes," This Week Times Two 11, no. 22 (Friday, April 18, 1975), FN 3, Chapter 2.

${ }^{264}$ Jill Vickers, “The Wheels Exceeding Slow!,” CUASA News 5, no. 4, (June 1975,): 1, FN 1, Chapter 2.

265 "Chairmen Included in Bargaining Unit Following Detailed Decision by OLRB," This Week Times Two 12, no. 9 (Thursday, July 10, 1975), FN 3, Chapter 2.

${ }^{266}$ Ibid.

${ }^{267}$ This decision set a significant precedent in Ontario and was the opposite of a later American decision regarding the managerial duties of departmental chairs. See conclusion and footnote 368 . 268 "Certification Issued, Chairmen in," CUASA News 6, no. 1 (July 1975): 1, FN 1, Chapter 2. 
Chemistry professor Don Wiles felt "considerable anguish" at the thought of a faculty union at Carleton University. ${ }^{269}$ Four days before members of the Carleton University Academic Staff Association (CUASA) cast their ballots in the Ontario Labour Relations Board (OLRB) representation vote, Wiles had made his thoughts public in a letter published in This Week Times Two. ${ }^{270} \mathrm{He}$ had been chosen as the association's president-elect in 1973 but had recently resigned this position when it became clear to him that other CUASA leaders would be applying to the OLRB for certification. His decision was a moral one: although he struggled with his conscience he could no longer belong to an organization that had contributed to the fracturing of the Carleton campus; this, at one time, had been "a single university community" in which everyone worked together towards the common goal of delivering "good education."271 As an academic, he believed that his duty was to teach, not "struggle against an enemy who used to be my friend. ${ }^{272}$

CUASA leaders were aware that many professors felt deeply about this issue and that the morality of their respective pro- and anti-union positions was primarily a function of workplace identity. For many dissenters, any anxiety caused by "financial stringency" was not strong enough to override the conviction that unionization was a form of group action incompatible with their role as self-governing scholars who, motivated primarily by duty rather than other concerns such as material gain. Professors who favoured certification might share this understanding of scholarly life but were also convinced that they had a right to equitable terms and conditions of work. This belief could have been

${ }^{269}$ D.R. Wiles, "Reasons for Resigning," This Week Times Two Special Edition (Thursday, April 10, 1975), FN 3, Chapter 2.

${ }_{270}$ Ibid.

${ }^{271}$ Ibid.

${ }^{272}$ Ibid. 
the result of a number of factors including gender. Indeed, some female academics in particular had seen union membership as a potential mechanism for changing the systemic disadvantages they experienced due to the gendered nature of the university. Given these conflicting perspectives, organizers had to carefully frame the case for collective bargaining to build consensus.

The CUASA executive members did not make any public appeal for reconciliation. Instead, they attempted to mobilize support through a process that was designed to be collegial. They emphasized the fact that certification would provide academic staff with the means to insist on the "rule of law" at Carleton without changing the democratic or academic nature of CUASA as an organization; unionization did not represent a fundamental change in scholarly identity. Although the campaign was not supposed to be “about the money," improvements to salaries and other monetary were frequently featured during the certification process. This contradiction suggests that although the occupational identity of professors seemed to preclude financial concerns, their occupational status was ultimately a [multi-faceted] moral economy.

Don Wiles was not alone in believing that a union endangered the essential nature of Carleton as a scholarly community — other opponents to certification stated similar ideas publicly. ${ }^{273}$ In a letter to the editor published in the March 11 issue of This Week Times Two, English professor Charles Haines contended that if CUASA became a "labour union," professors would in fact be shifting "the philosophical basis of our

${ }^{273}$ See also for example W.E. Walther, "No Redundancy at Carleton," CUASA News, 5, no. 1 (October 1974): 1, FN 1, CHAPTER 2; Douglas Wuertele, "No Final Solutions," Opinion Forum, CUASA News 5, no 3 (January 1975): 1, FN 1, Chapter 2. 
profession. ${ }^{, 274}$ Like Wiles, Haines envisioned the university as a distinct society, "a confederation against ignorance" made up of not just professors but also administrators, non-academic staff and students. Within this "Union," professors were "masters of our universe," and the basis for teaching and research was freedom. From his perspective, "to sacrifice any part of our liberty ... perhaps to gain a measure of security in return, is to undermine the very principles that induced us all, at the outset of our careers, to become University Professors. ${ }^{, 275}$ Economist Thomas Rymes was less genteel in his comments. In his letter to the editor in the same official Carleton newsletter, he stated bluntly that those who supported unionization were condoning a form of "group coercion" that posed the "gravest threat" to core values such as academic freedom and integrity. To be members of a union would put Carleton professors in an "intolerable" situation that could “"close' our academic community."276

Although these professors did not necessarily belong to the first generation of "Carletonians," their definition of scholarly work was in the tradition of professors such as Donald Rowat. As academics, they were independent members of a democratic selfgoverning community and their relationships were not predicated on the "the masterservant relationship found in industry and government"; they worked collegially and were "citizens" ${ }^{\text {"277 }}$ of the university rather than institutional employees. Moreover, their work as teachers and researchers was a vocation. Inherently, they were motivated by a commitment to their students and the greater goal of producing and sharing knowledge. A

\footnotetext{
${ }^{274}$ Charles Haines, "More on Unionization," This Week Times Two 11, no. 13 (March 11, 1975), FN 3, Chapter 2.

${ }^{275}$ Ibid.

${ }^{276}$ Thomas K. Rymes, “Threats from Within,” This Week Times Two 11, no. 6 (Friday, February 7 , 1975), FN 3, Chapter 2.

${ }^{277}$ See, for example, Rowat, "Faculty Participation in Canadian University Government."
} 
union was a form of occupational organization antithetical to this ideal of scholarly work for at least two reasons. ${ }^{278}$ One, the key purpose of collective bargaining was to improve the financial position of union members. Engineering professor David Coll had "worked on construction" with his dad while doing an undergraduate degree at McGill University and this may have been when he began to define unions as organizations designed to ensure that workers got their fair share of company profits, a goal with which Coll had "no truck." ${ }^{279}$ Two, strike action necessitated a withdrawal of labour. Professor Blair Neatby agreed in principle with his pro-union colleagues that "unions were a good thing. ${ }^{, 280} \mathrm{He}$ had had no personal exposure to unionized workers or workplaces during his childhood in rural Saskatchewan but as a Canadian historian he had developed a "very favourable view" based on his study of union formation in Canada. ${ }^{281}$

They were protecting the workers against the exploitation of capitalists and so on. And, you know, that's out of the 20s, the 30s, into the 40s. That's my background. So, as far as unions ... abstractly were concerned, they were ... part of democracy. ${ }^{282}$

In addition, unlike some professors, Neatby saw himself as an employee; academics did not exist in a rarefied world, separate from the world around them because "their very existence depended upon the colleges or universities which employed them."283 Nonetheless, he agreed with both Wiles and Coll that unions did not belong in universities because this form of labour relations inevitably presented a conflict of interest. Unionized employees had the right to "defend themselves by going on strike" and Neatby believed that at an academic institution, "it wasn't fair ... The students would

\footnotetext{
${ }^{278}$ Rowat, "Faculty Participation in Canadian University Government," 473.

${ }^{279}$ D. Coll, oral history.

${ }^{280}$ B. Neatby, oral history.

${ }^{281}$ Ibid.

${ }^{282}$ Ibid.

${ }^{283}$ Ibid.
} 
suffer [and] why the hell should you allow unions to interfere with your relationship with students and the benefit to students? ... So I was opposed to unions."284

Andrew Brook might have been surprised that Coll, Wiles and Neatby stood on such solid common ground because his perception during the certification campaign was that "the biggest split" was between those faculty members who were in "the basic teaching research units" and those in "the professional schools." ${ }^{285}$ Although Carleton did not offer degrees in the traditional professions of law, medicine or theology, the university did have programs in professionalized fields such as social work, architecture and engineering and apparently faculty members in the latter discipline were particularly vocal about their lack of enthusiasm for unions. ${ }^{286}$ Coll knows that at that time, "we considered ourselves out of it. There was no way. We were professional faculty, we were not going to be subject to the rule of socialist sociologists." 287 Brook attributes such resistance to the fact that engineers assumed that their professional associations, such as Professional Engineers Ontario, would act on their behalf. ${ }^{288}$ Moreover, his observation then was that engineering faculty often worked as private consultants while being employed on campus. Given that consultancy was far more lucrative than teaching at Carleton, they were less vested in the university; it was not a "community venture" for them as it was "with academics who weren't professionals.",289

${ }^{284}$ Ibid.

${ }^{285}$ A. Brook, oral history. Nelson describes the tensions at the University of Toronto between the professors from the Arts and Sciences faculty and those from the professional faculties. Apparently those from the professional disciplines (e.g., law and medicine), favoured "virtual representation" and consultation with the university president rather than more formalized collective bargaining. Nelson, Searching for Faculty Power, 102-04.

${ }^{286}$ Ibid.

${ }^{287}$ D. Coll, oral history.

${ }^{288}$ Ibid.

${ }^{289}$ Ibid. There is considerable debate in the academic literature on the issue of the professionalization of occupations. As William Goode pointed out in 1961, "Spokesmen from almost every recognized white- 
Engineering faculty members did take some actions that seemed to substantiate Brook's suspicions. On March 19, 1975, Professor D.A.J. Miller wrote to the registrar of the OLRB on behalf of members of the Carleton Engineering Faculty Association (CEFA). Miller was the pro tem chairman of the CEFA and the purpose of his letter was to request the assurance of the OLRB that the "rights" of engineers as a "special unit" within CUASA be enshrined in the board's decision on the faculty association application for certification. He indicated that members of the engineering association also belonged to CUASA and would support the certification application on the understanding that, "the special interests of our faculty and its members, being professional engineers as well as professors, would be recognized and actively protected by CUASA. ${ }^{290}$ Nonetheless, as a "minority" group of approximately sixty professors within CUASA, they were aware that future association leaders would not necessarily honour the agreement that the engineers had negotiated with the current "fair-minded" CUASA executive council. ${ }^{291}$ Specific "recognition" of this group in the OLRB decision would further protect their position as would support from the Federation of Engineering and Science Association, assistance that the group was also pursuing. ${ }^{292}$

collar workers have asserted that they are professional." Although there are various approaches to defining professionalism, Goode represents one of the dominant schools of thought, which identifies professional occupations in terms of key traits such as accredited specialized, technical work, autonomy, a code of ethics and a commitment to service. As a result, these are occupations that lead to a career rather than simply a series of jobs. Some academics, such as David Coll, refer to themselves as professionals because they do belong to an accredited occupation such as engineering. Others may use the term more broadly. There has certainly been debate amongst academics as to the suitability of this term for scholarship and Blair Neatby rejected it outright in 1986, writing that, "university professors in Ontario do not constitute a profession. They do not license practitioners or regulate their conduct." William J. Goode, "The Librarian: From Occupation to Profession?," The Library Quarterly 31, no. 4 (October 1961), 307. Blair Neatby, "The Academic Profession," 10. See also Harold L. Wilensky, "The Professionalization of Everyone?," American Journal of Sociology 70, no. 2 (September 1964), 137-58.

${ }^{290}$ D.A.J. Miller, Letter to the registrar of the OLRB, March 19, 1975, Carleton University Academic Staff Association fonds, CUASA-002, Carleton University Corporate Archives, Ottawa, Ontario. ${ }^{291}$ Ibid. ${ }^{292}$ Ibid. 
While the identity of engineering faculty was strongly influenced by their professional accreditation, individuals could find that they shared some of the concerns of fellow academics from other disciplines. Coll voted against certification because he had a deep loyalty to the traditions of professional engineering and academia and, in particular, to the autonomous, individual nature of work in both fields and to the idea of career as vocation. ${ }^{293}$ He still thinks that academic staff should not be union members as a membership in such a group contradicts the individual's responsibility for his or her research and teaching. Moreover, like Neatby he believes that as a teacher he has an ongoing duty to his students that precludes his withdrawal from the classroom and, as such, he "couldn't conceive of strike" where the loss of even two weeks would be destructive for students enrolled in short (twelve to thirteen weeks) terms. ${ }^{294}$

Professors who supported unionization recognized that to some extent their ideas about university life were similar to those of their opponents - even those in very different disciplines. Andy Brook agreed with his engineering colleagues on some key work-related issues.

I can make common cause with people in engineering over any number of academic governance issues. Because ... we value good research in the same way and we value picking the best possible students we can find each year in the same way. And so at that level of generality, yes, there certainly is a community of interest and a community of scholars. And a general feeling ... that we have to run our own shop because nobody else understands the shop well enough to do it properly. ${ }^{295}$

They also knew that their experiences and concerns could vary significantly from those of other professors, and believed that some dissimilarity between faculty members was due to inherently unfair working conditions. Inequities could be explained in terms of the

\footnotetext{
${ }^{293}$ Ibid.

${ }^{294}$ Ibid. Coll is a member of Professional Engineers Ontario.

${ }^{295}$ A. Brook, oral history.
} 
hierarchical nature of the institution embedded in the corporate model of governance that gave professors less control over decision-making than the ideal of the "community of scholars" promised and led to decisions by senior administrators that seemed arbitrary. Pro-union faculty also attributed inequity to additional factors, such as gender and age, which defined them as the "new type" on campus with a relatively low occupational status. For these professors, joining a union was a viable strategy for improving their status because they believed that their work as scholars did not preclude belonging to a labour organization, given that they were motivated by a desire for fairness rather than monetary gain. This was the position of some of the female faculty members who supported certification. ${ }^{296}$

Women had been employed as teachers and researchers at Carleton since the 1950s and early 1960s and the first generation was aware that female faculty members were in a minority. Professor Naomi Griffiths was hired for the 1961-1962 academic year and she can still name all her colleagues in the history department, none of whom were women: "David Farr, Desmond Bowen, John Moyer, Stan Mealing and Gordon

\footnotetext{
${ }^{296}$ I am not analyzing unionization explicitly in generational terms. As I will discuss in the conclusion, this is an area for further study because the tensions between "generations" is palpable in the oral histories and it is important to recognize that individuals see themselves as belonging to a cohort so this dimension of their identity is significant. Again, there are a variety of approaches to defining the concept of generation. However, Glen H. Elder's life course framework could prove to be useful in understanding the role that life span played in collective action at Carleton, in particular because he is interested in the intersection of agency and social structure. Elder suggests that while age is "a basic element of social structure," it is important to recognize that its meaning should not be reduced to chronological age. Instead, it is important to consider life span, social timetable and historical time in the course of a life or lives in order to begin to understand the function of age in social action and how "cohorts" or groups of people together at the same historical moment function. As such, when organizers at Carleton speak about the "older" wives or the "newer sorts," these are not terms that strictly refer to chronological age. In addition, he suggests that "human agency is inextricably social, structured by interactional situations" and thus influenced by the life course of individuals. As such, not only do gender and status have a role to play in collective action, but could be, in fact, bound up in individual life courses that intersect to create a specific historical cohort. See Glen H. Elder, Jr., "Age Differentiation and the Life Course" Annual Review of Sociology 1 (1975): 165; and Steven Hitlin and Glen H. Elder, Jr., "Time, Self, and the Curiously Abstract Concept of Agency," Sociological Theory 25, no. 2 (June 2007): 185.
} 
Couse. ${ }^{297}$ Griffiths understood that she could face discrimination in the workplace and, at the very least, be paid less than her male counterparts as she had been when she was a teenager working the Parker pen factory in England and "got paid a shilling and the boy next to me got a shilling and a penny." ${ }^{298}$ Nonetheless, Griffith's memory of her university career is positive. She began her academic life in a period when "women had as much difficulty going on as anybody" and was grateful that "somebody is paying me to do something I love. ${ }^{1299}$ Moreover, she speaks fondly of the other professors in the Carleton history department who acted as mentors during the early years of her academic life and helped, assistance, which facilitated a career that led to her appointment as the first female dean of a large arts faculty in Canada. Blair Neatby's impression is that women such as Griffiths may have been representative of her cohort of female academics, which included his aunt, well known Canadian historian Hilda Neatby.

Once you got hired, most women, in my experience, I mean I'm talking of some senior ones like my aunt ... would say ... "There's no prejudice once you're a member of the department." And so that was ...the attitude of most female professors, that once they got there they were treated like colleagues ... It may well be, that the men didn't have as much respect for women professors as they did for male professors. Because there was ... this sexism at the time ... I think they might have been more militant than they were in fact. ${ }^{300}$

The new and younger generation of female professors being hired at Carleton in the 1970s were willing to be more militant and to voice their dissatisfaction with the poor status of women on campus that subjected them to unfair treatment such as sexual harassment. ${ }^{301}$ Not only did they want improved and more equitable terms and conditions

${ }^{297}$ N. Griffiths, oral history.

${ }^{298}$ Ibid.

${ }^{299}$ Ibid.

${ }^{300}$ B. Neatby, oral history.

${ }^{301}$ Ibid. For example, former University of Toronto ( $U$ of T) professor Jill Ker Conway and colleague Natalie Zemon Davis were involved in the struggle for day care at U of T in the early 1970s. Jill Ker Conway, True North: A Memoir (Toronto: A.A. Knopf Canada, 1994), 192-94. 
of work but they were prepared to take direct action to achieve their goals. CUASA president Professor Jill Vickers belonged to this cohort. Vickers had become involved in the faculty association partly because she was in favour of work-based organizations so an active role in the association was a "good fit ... It wasn't then a union but I thought 'Okay, this is a probably interesting thing to be doing'... And I'm good at organizing and I'm a very persuasive speaker. So I was asked if I wanted to do it and I said sure." ${ }^{302}$ She was already familiar with collective bargaining and unions when she began working at Carleton. Vickers, who was born in England, had spent her early childhood southern Ontario, first in Hamilton and then Toronto. Her father was a tire builder and "union guy" who frequently walked the picket line and she has an early memory "of sitting on a piano, singing something while they were all on strike. ${ }^{303}$ Living in the Toronto area with its then robust manufacturing and tertiary sectors, she later had the opportunity to work in both factories and organizations such as the Bell Telephone Company and became involved in labour issues and organizing campaigns because she was "philosophically committed. ${ }^{304}$

When she was just out of high school, she worked at the Bell Telephone Company, and participated in a union drive. This was a pivotal experience that "ended badly.",305

I got fired ... for someone just from Grade 13, I was very well paid in those days as a business agent ... But if you do anything ... it was not [the] absence of the "rule of law", it was a really heavy weight of stuff coming down from the top which I found very difficult. There was a union ... Danforth was the hotbed of unions in those days and I was at the Danforth branch. ${ }^{306}$

${ }^{302}$ J. Vickers, oral history.

${ }^{303}$ Ibid.

${ }^{304}$ Ibid.

${ }^{305}$ J. Vickers, oral history. See also Sangster, "The 1907 Bell Telephone Strike" for an account of earlier job action by female Bell employees.

${ }^{306} \mathrm{~J}$. Vickers, oral history. 
She did her doctoral work in political science at the London School of Economics and arrived at Carleton in 1969 to teach at St. Patrick's College. By this time, Canadians were "getting to the height of the women's movement" and Vickers was an active participant because she thought women could, and should, demand significant economic, social and political gains. ${ }^{307}$ This general belief was reinforced by her own negative experiences at Carleton such as being assigned evening courses by a departmental chair who was "a real SOB ... who thought that you had a kid, 'Oh well we'll make you teach at night'.,308 Vickers attributed poor and unfair treatment generally to the lack of "rule of law" on campus. While a company like Bell Telephone was characterized by too many procedures and a heavy-handed leadership style, she had experienced the difficulties occasioned by the discretionary powers collegiality granted to colleagues in positions of authority. In her eyes, Carleton suffered from a lack of contractual rules that placed employees at a disadvantage because there were no consistent standards for determining how they were to be treated. These problems were compounded for women as a result of gendered practices and expectations. For example, the fact that hiring practices were loose and new faculty members were expected to bargain their starting salaries represented a particular challenge for women: she observed that they "don't bargain" and, as a result, would start their careers at the university with salaries that were significantly lower than those of their male colleagues - a gap that could be difficult to eliminate over the course of a career. Her initial salary was $\$ 9,000$ and she estimates she was paid between $\$ 1,000$ and $\$ 1,500$ less than men with the same qualifications at the time- a

\footnotetext{
${ }^{307}$ Ibid.

${ }^{308}$ Ibid.
} 
significant "financial handicap." ${ }^{309}$ Vickers contends that if a woman worked for a dean who was "enlightened," she might be treated fairly, not just in terms of her salary but also if she requested other benefits such as maternity leave. ${ }^{310}$ In the absence of collective agreement, even the policies and procedures that did exist at Carleton did not protect women or men because "the rules they did have ... [were] applied depending on circumstances, because there was no arbitration, there was no appeal process."’311

Many male faculty members also supported the principle of equal rights for Carleton employees, and many had arrived at the university with previous union-related experience or exposure. Andrew Brook, who became the CUASA president in $1976^{312}$ and is a self-described egalitarian, has always thought that faculty were overpaid relative to other workers and should be encouraged to consider whether salary increases proposed for academic staff were "adequate, not adequate, or too high." ${ }^{\text {"313 }}$ Like Vickers, he was in favour of certification because he wanted "a fairer and more public method of determining conditions of employment than the one we presently have;" he was contemptuous of colleagues like Thomas Rymes who seemed to be resisted unionization because they benefited from "the present system.."314 His support for organized labour pre-dated his joining the faculty at Carleton, in part because his father had been a "strong trade unionist" so Brook was "sympathetic to those traditions." "315 Other colleagues, such as journalism professor Joseph Scanlon, had been union members in earlier periods of

${ }^{309}$ Ibid.

${ }^{310}$ Ibid.

${ }^{311}$ Ibid.

312 "CUASA Steering Committee 1975-76," CUASA News 6, no. 4: 2 (October 24, 1975), FN 1, Chapter 2.

${ }^{313}$ A. Brook oral history.

${ }^{314}$ Andrew Brook, "Reply to Professor Rymes," This Week Times Two 11, no. 8 (February 14, 1975), FN 1, Chapter 2.

${ }^{315}$ Ibid. 
their working lives; Scanlon believed that a "union contract" would neither alter the collegiality of the university community nor an individual faculty member's ability to bargain with senior administrators on issues such as salaries. ${ }^{316}$ And there were professors like political economist Leo Panitch, who did not have previous union involvement but recognized collective action as "the only real power we have" institutionally. ${ }^{317}$ Given that professors had limited input into the financial and administrative decision-making on campus, "part of the motivation behind certifying was to achieve some democratic control over the operation of the institution"318 — a goal with roots reaching back to Rowat's advocacy for greater faculty involvement in university governance.

Memories of this period suggest professors understood that different facets of faculty identity — occupation, gender, age — could intersect and reinforce support or opposition to certification, as they could help bridge divisions between professors. Vickers, a self-described "new type," felt part of a peer group that was distinct from "the older people ... from First Avenue."319 These "Old Carletonians" made up the cohort that had worked at the college in Ottawa's Glebe neighbourhood and been committed to building Carleton as a university. She remembers them as having "the sense that we should be a very co-operative, collegial place" as the college had been and that a union would counteract that spirit. ${ }^{320}$ She was also aware that collegiality was not always a reason to oppose unionization - it could in fact encourage established faculty members

\footnotetext{
316 Joseph Scanlon, "Why Collective Bargaining (II)," CUASA News Special Edition (February 5 , 1975): 2, FN 1, Chapter 2.

${ }^{317}$ Leo Panitch, "Why Collective Bargaining (1)," CUASA News Special Edition (February 5, 1975): 1, FN 1, Chapter 2.

${ }^{318}$ A. Brook, oral history

${ }^{319}$ J. Vickers, oral history.

${ }^{320}$ Ibid.
} 
such as Blair Neatby to support unionization in order to protect the needs of "the younger people. ${ }^{321}$ Neatby sympathized with some of his young colleagues worries about being fired, even if he was not in their position: he "didn't give a damn",322 about threats of firing because his career was well established: "I had a $\mathrm{PhD}$ and I was a full professor, and ... I published ... I never thought of being fired." ${ }^{323}$ Despite his personal and ethical aversion to unions, and the lack of fear for his own future, he chose to publicly announce his support for certification as an act of solidarity with his departmental colleagues. His thinking at the time was:

I want to maintain a sense of community within the history department ... I don't want a division ... between the senior people like me, and the junior people ... it's important for the department not to be torn apart on this, and so if I come out in favour, because by that time I was a pretty senior figure, ... then at least the younger people who are agitating, or the people from St. Pat's ... won't feel that ... they're being rejected because they're just junior ... I was strongly committed to a sense of community within the department. ${ }^{324}$

Despite these tensions between faculty on the issues of unionization, ultimately pro- and anti-union professors were relatively united on one important point: academics should belong to an association, not a union. Canadians in the traditional professions, such as doctors, had formed their own voluntary associations and used these organizations to advance their occupational interests. ${ }^{325}$ Other work-related groups such as professors and librarians had followed suit, and although such organizations were often initially social clubs, over time members did engage in economic or advocacy activities as the occupational status of a given group evolved. ${ }^{326}$ Nonetheless, these

${ }^{321}$ Ibid.

${ }^{322}$ B. Neatby, oral history.

${ }^{323}$ Ibid.

${ }^{324}$ Ibid.

${ }^{325}$ For example, Richard A. Wier, "Federalism, Interest Groups, and Parliamentary Government: The Canadian Medical Association," Journal of Commonwealth Political Studies 11, no. 2 (1973): 159-75.

${ }^{326}$ Bruneau, A Matter of Identities. 
groups had long distanced themselves from the labour movement and would not accept to negotiating or bargaining on behalf of members. At Carleton, these boundaries were clearly understood: "CUASA, literally it was an association and it wasn't a union." ${ }^{, 327}$ The distinction was more than simply semantics—it was ideological. Vickers joined CUASA because she wanted to be actively involved in addressing workplace issues and thought that it would be "a venue for trying to do some of those things." ${ }^{328}$ Although she came from a union family and had labour experience, as an academic she was cautious about joining an external labour union such as CUPE. Representatives from CUPE had been lobbying faculty at other institutions to join, most recently at St. Mary's University in Halifax, where the debate amongst professors over the best form of collective action had become quite heated. ${ }^{329}$ From Vickers' perspective, the trade union was not suitable for Carleton.

There was a question as to whether we would get a union like CUPE ... they were kind of hanging around, and certainly we had some quite left wing people who thought it was a good idea ... I was less enthusiastic ... we weren't unionizing for money, we were unionizing for the rule of law. ${ }^{330}$

Her distinction could seem contradictory, but it illustrates the importance of status or what Blair Neatby calls "prestige" in the drive to unionization. Even professors such as Vickers, who understood that they were employees and recognized the need for collective bargaining, also wished to maintain their occupational status as workers who were driven less by economic need than by philosophical commitment.

${ }^{327}$ N. Griffiths, oral history.

${ }^{328}$ J. Vickers, oral history.

${ }^{329}$ See for example, Jensen's "Dodging the Steamroller," for an account of the struggle between CUPE and CAUT to certify the professors at that university.

${ }^{330}$ J. Vickers, oral history. 
As such, scholarly values were central to the certification campaign run by Vickers and her fellow CUASA council members. The process for gaining consensus was democratic and open, reinforcing the CUASA council's commitment to the principles of collegiality and academic freedom. The written communication from organizers to members-at-large presented unionization as an effective tactic for responding to the immediate problems - inadequate government funding and a president who would not protect professors - and for regularizing the long-term relationship between faculty members and senior administrators that would not contradict the egalitarian nature of either CUASA as a faculty association or of the scholarly community in general. It is interesting, however, that even if participants remember the case for certification being grounded in the need for the "rule of law" rather than financial gain, monetary issues such as salary increases were discussed, particularly in the issues of the CUASA newsletter (CUASA News) published during the campaign. The inclusion of these issues suggests that at least some professors considered equitable terms and conditions of work to include fair salaries and benefits. Certification was achieved with support from a majority of faculty, perhaps because they were reasonably convinced that this form of protection was needed and could be reconciled with occupational identity.

Although occupational status was a key factor in the unionization of faculty at Carleton, so too was the lack of resistance from university administrators. Unlike the experiences of Canadian industrial workers in the early $20^{\text {th }}$ century who faced great opposition from company representatives or those in the Canadian public sector whose employer had the legal authority to deny them the right to organize until after World War II, the senior administrators at Carleton, including members of the Board, did not engage 
in a counter campaign to prevent certification. In addition, CUASA organizers were careful not to frame unionization in terms of collective bargaining in terms of women's rights or gender quality.

According to Andrew Brook, the period of the campaign between October 1974 and June 1975 was an "incredibly busy" time as a small number of organizers attempted to engage professors in the issue of collective bargaining; this was a challenging task given the fact that amongst the many faculty who had belonged to CUASA, few had participated in the on-going work of the organization. ${ }^{331}$ The campaigners approached the certification drive as an inclusive process, using a number of tactics to involve as many academic staff as possible in the decision to unionize. As per the CUASA constitution and bylaws, they continued to hold regular council meetings as well as general members' meeting and reported to members on these activities. They also reached out to colleagues via a small team of faculty members who "spent a lot of time knocking on doors every day," trying to sign up a majority of the over 600 faculty currently working on campus, including the most vocal anti-union groups such as the engineers. ${ }^{332}$ In addition, members of CUASA's collective bargaining committee hosted the two-day education sessions in January as a public forum for discussing unionization and all faculty and librarians were invited to attend.

These strategies were consistent with the traditions of the "community of scholars," collegiality and academic freedom. CUASA was structured as an autonomous association, governed by its members; earlier that year, the previous council had even introduced a new "constitutional structure" to encourage greater member participation, including the

${ }^{331}$ A. Brook, oral history; Jill Vickers, "President's Report," CUASA News 5, no. 1 (October 1974): 1, FN 1, Chapter 2.

${ }^{332}$ A. Brook, oral history. 
election of a higher number of representatives. ${ }^{333}$ Regular and special meetings were integral to an egalitarian approach to decision-making and to ensuring that association officers were accountable to the membership. Efforts to communicate broadly provided opportunities for all professors to meet as peers and freely examine the issues, in open face-to-face forums. These tactics conveyed the message that a certified CUASA would protect the interests of members in the same way.

Effective communication was central to the success of the campaign and, in addition to the various formal and informal gatherings, the council revamped the association newsletter. The CUASA News became a critical outreach tool for organizers and facilitated their attempts to circulate information widely across campus. ${ }^{334} \mathrm{An}$ analysis of the issues published between October 1974 and June 1975 shows how CUASA representatives used both text and graphics to frame the question of unionization in order to counter dissent and mobilize support. Early issues included some material from opposing points of view but this information was limited; the editors did not print any letter or article similar in tone and position to those of Professors Wiles, Rymes and Haines that appeared in This Week Times Two, the university's official campus newsletter, during the same period. ${ }^{335}$ In the period leading to the representation vote, those selecting the content included only that which supported the case for unionization.

The first issue of CUASA News appeared in October 1974 when CUASA leaders were discussing the possibility of unionizing but had not yet taken any formal step. In her

\footnotetext{
${ }^{333}$ J.M. Vickers, "President's Report," CUASA News 5, no. 1 (October 1974): 1, FN 1, Chapter 2.

334 The CUASA website publishes an archive of association newsletters but no copies are posted for the years between 1971 and 1974. The name appears with CUASA both punctuated and not. As per Chicago style, I have chosen not to include punctuation.

335 There is no evidence to suggest that the editors of CUASA News censored material submitted for publication that represented an opposing view. However, the lack of such material in the newsletter is noted.
} 
inaugural president's report, Vickers hoped that the new format would motivate more members to become involved in CUASA activities. ${ }^{336}$ The last version of the association newsletter which had been produced in 1971 had the "look and feel" of meeting minutes, whereas the current publication featured many of the key elements of documents produced to persuade, influence and inform readers: column layout for text, nameplate, volume and issue information, and images such as cartoons. ${ }^{337}$ Of the eight newsletters published during the campaign, three were "regular" in content and design. Typically two pages in length, each included not only standard columns such as the president's report, committee notes and council meeting summaries, but also work-related announcements such as a notice about upcoming OCUFA teaching awards and opinion pieces from faculty members on topics of concern such as the redundancy document. If the five "special" issues were specifically dedicated to collective bargaining or developments in the certification drive, every newsletter addressed the issue of unionization to some extent.

In addition to introducing the revamped format, Vickers constructed the foundational frame for certification in her initial column. She foresaw looming challenges for faculty members, brought on by the reaction of senior Carleton administrators to external factors. Changes in provincial public policy were creating a more complex operational environment for universities in Ontario. In response, Carleton's "administration" seemed to be adopting an alarming "management philosophy" that, in

${ }^{336}$ Vickers, "President's Report."

${ }^{337}$ See for example, Phillip Lesly, ed., Lesly's Public Relations Handbook, $2^{\text {nd }}$ ed. (Englewood Cliffs, New Jersey: Prentice-Hall, Inc., 1978), 540; Patricia Hagwood, "Newsletters," in International Encyclopedia of Communications, ed. Erik Barnouw (New York, Oxford: Oxford University Press, 1989), 178. 
turn, was complicating its relationship with CUASA members - a not so veiled reference to the leadership of Michael Oliver. As a result, faculty members were at a crossroads.

They needed to re-evaluate their traditional approach to working with university administrators in the face of the new "professional" and "planning oriented" approach to decision making so that the association could "re-establish our right to negotiate benefits." 338 The provincial and national faculty organizations, CAUT and OCUFA, were already considering two new methods for securing fair working conditions for professors: a two-tier provincial negotiation program, and collective bargaining. In addition, Canadian faculty unions had been formed: Notre Dame of Nelson, British Columbia, St. Mary's University in Halifax, Nova Scotia and the University of Manitoba. ${ }^{339}$ By implication, these options were open to Carleton professors.

The next issue was published in December and the headline for the president's column was “C.U.A.S.A. Takes the Plunge??” As Vickers reported, collective bargaining was no longer a theoretical proposition but a serious possibility for at least some Carleton faculty. Although the association council and steering committee would have preferred to take "cautious and deliberate steps" towards a decision on unionization, individual members were exercising their democratic right to table the issue for immediate discussion. Their sense of urgency was again attributed directly to President Oliver; their feared that he would "internalize the systemic problems" caused by a lack of adequate provincial funding and close academic programs. CUASA representatives were prepared to address these concerns: a collective bargaining committee was in place and mandated to provide members with information as well as a forum for discussion; the council

\footnotetext{
${ }^{338}$ Vickers, "President's Report."

339 Donald C. Savage, "Special Report. Collective Bargaining: The State of the Nation," CAUT/ACPU Bulletin 23, no. 1 (September 1974): 10.
} 
would continue to act according to accepted procedures to promote debate and decisionmaking within the association; and they were advocating for professors by participating in university-level discussions such as those happening at the Academic Planning Committee. However, CUASA members at large needed to become more engaged - in discussions about unionization and the association in general - to ensure that their concerns were properly aired.

Collective bargaining was the primary focus of the next newsletter. The front page announced the upcoming January study sessions, and more than half of the ten-page issue was devoted to background material on the "pros and cons" of unionization, mainly through reprints from other organizations; dissention was permitted, alternative course of actions would be considered. There were also an OCUFA update on its proposed two-tier provincial bargaining model, as well as letters from Carleton faculty printed in the “Opinion Forum," including one in which Professor Douglas Wurtele proposed that a solution to the current problem of potential firings was for faculty to find "fair minded ways to cut the cost of operations," such as salary decreases. ${ }^{340}$ Vickers and other CUASA council and steering committee members did not print their own editorials advocating in favour of unionization. Instead, members were "urged to consult" not only the information printed in the newsletter but a number of other sources such as recent CAUT bulletins and Adell and Carter's Collective Bargaining for University Faculty in Canada, in preparation for the study sessions at the end of the month. ${ }^{341}$

${ }^{340}$ Douglas Wurtele, "No Final Solutions," CUASA News 5, no. 3 (January 1975): 6-7, FN 1, Chapter 2; B.L. Adell and D.D. Carter, Collective Bargaining for University Faculty in Canada (Kingston, Ontario: Industrial Relations Centre, Queen's University, 1972).

${ }^{341}$ CUASA News 5, no. 3 (January 1975): 1, FN 1, Chapter 2. 
Perhaps the best articulation of the pro-union position was contained in the following issue, printed in early February after the educational workshops had been held. Leading with the headline "CUASA Takes the Plunge," the top news items reported briefly that the members had approved the constitutional amendments necessary for certification. However, the majority of space in the newsletter was used for three prounion editorials. "Why Collective Bargaining (I)" and "Why Collective Bargaining (II)"expressed the views of Carleton professors Leo Panitch and Joseph Scanlon respectively while the third, "CAUT and Collective Bargaining," was the "personal view" of CAUT executive director Donald C. Savage. Each piece varied in tone: Panitch's was more militant, including references to unfair wages, "naked market forces," and the need for collective power that other professional groups had already harnessed; ${ }^{342}$ Scanlon's was essentially pragmatic, emphasizing his own experience that unions did not ruin the workplace; and Savage's seemed intent on soothing concerns by pledging the endorsement and support of the national organization. The three authors were united in maintaining academics need not be afraid of unionization because the labour laws were flexible enough to accommodate more than one type of employee group. If professors were not inclined to combativeness and strike action, they could use the legal framework to achieve their own goals: the protection of traditional scholarly values and a fair deal. As Savage concluded, "collective bargaining is not a break with the past but a new device to realize old ends - a real input by faculty into the decision-making process, and the entrenchment of academic freedom and due process." 343

\footnotetext{
${ }^{342}$ Panitch, "Why Collective Bargaining (1)," FN 1, Chapter 2.

${ }^{343}$ Donald C. Savage, "CAUT and Collective Bargaining," CUASA News Special Edition (February 5, 1975): 2, FN 1, Chapter 2.
} 
While the tenor of the first few issues was reasonably measured, organizers became increasingly polemical in the period leading up to the representation vote. The OLRB's insistence on the vote appears to have caught CUASA organizers off guard, as Vickers and others believed that they "shouldn't really have had to have a vote in the sense that we'd signed up such a large portion of people." ${ }^{344}$ However, Vickers now believes that the vote strengthened the position of CUASA organizers because the positive outcome was perceived as a clear, public statement that a majority of professors were in favour of collective bargaining. "It was probably the best thing that happened because a whole lot of people who'd assumed that it was a soft unionization, i.e., a lot of people that are probably on hand in the heat of the moment actually came out and voted for us., 345

At the time, however, the vote threatened unionization by allowing the renewal of many fears. ${ }^{346}$ CUASA council published two newsletters just prior to the vote, one on April 8 and the other on April 10, and each was used to convince faculty not only to vote but to vote "CUASA-Yes!" and "Yes! To protect Carleton." 347 The "problems ahead in the provincial system" were profiled and, as Professor Cooper Langford, wrote "new structures are necessary now in the University to respond to new structures developed by government. ${ }^{348}$ Reprinted was a congratulatory telegram from the current CAUT president, Richard Spencer "U.B.C. engineering prof.," who reinforced the support of faculty associations across the country, and urged CUASA members to vote in favour of

${ }^{344} \mathrm{~J}$. Vickers, oral history.

${ }^{345}$ Ibid.

${ }^{346}$ CUASA News Special Edition (April 10, 1975): 1, FN 1, Chapter 2.

${ }^{347}$ CUASA News Special Edition (April 10, 1975): 1 and 3, FN 1, Chapter 2.

${ }^{348}$ C.H. Langford, "The Problems Ahead in the Provincial System," CUASA News Special Edition (April 10, 1975): 2, FN 1, Chapter 2. 
certification, as did OCUFA Chairman Norma Bowen. And for the first time, the prospect of "raiding" by an outside union was introduced. A short notice in the April 8 edition of CUASA News alerted faculty to the fact that the OLRB decision,

has reduced the fear that another non-academic union unaffiliated with either CAUT or OCUFA might move in and organize discontented faculty. If the Board had denied CUASA status, the only route left to Carleton academics would have been a union unrelated to CUASA. ${ }^{349}$

The warning was unmistakable: if the vote was unsuccessful, faculty would have no representation until CUASA could reapply, a process that would take at least six months and leave professors vulnerable to the organizing efforts of another labour group. ${ }^{350}$ The article does not specify a particular union, but the author might have been referring to CUPE. The public employee union had actively attempted to certify a faculty union at St. Mary's University in Halifax. ${ }^{351}$

In the final campaign issue of CUASA News of June 1975, Vickers' presidential column had a distinctly testy tone. She was impatient with the slowness of the process and the lack of a final ruling from the OLRB on the inclusion of departmental chairs in the bargaining unit. She no longer framed the challenges facing professors in terms of their relatively unprotected status but in terms of the on-going need for a united effort as professors headed into the first round of negotiations with university representatives.

Their redefined relationship with senior managers demanded a new "sophistication" and members would have to be actively involved to maintain the "grass roots" nature of the association and to prevent CUASA from becoming a more bureaucratic organization. ${ }^{352}$

349 “Labour Board's Decision Reduces Fear of Non-Academic Union Moving Into Carleton," CUASA News Special Edition (April 8, 1975): 4, FN 1, Chapter 2.

350 Ibid.

351 Jensen, "Dodging the Steamroller."

${ }^{352}$ Vickers, "The Wheels Grind Exceedingly Slow," FN 1, Chapter 2. 
The first steps included completing the CUASA survey on bargaining issues and participating in the upcoming council elections. Other items in that issue included the notification that no salary increases would be announced prior to negotiations, a short report that faculty at the University of Ottawa had launched their own certification drive, and a recommendation that if the administration offered a "golden hand shake" to faculty as a cost-cutting measure, individuals should consult CUASA council members to ensure that such an option was in their best interests. CUASA's active role in representing members continued as always.

Humour, as well as persuasive text, was used in newsletter content to gain consensus. The central messages of the certification drive were conveyed not only through written material but also through cartoons. Throughout the campaign, strategically chosen comics appeared in the publication and illustrated the key theme of the case for unionization: the vulnerable status of professors. Starting in the December 1974, small images appeared in five issues that reinforced key threats. For example, because higher education was no longer a public priority, professors could become "extinct," particularly because senior management was not trustworthy, specifically Michael Oliver, who would stoop to wearing a "shabby" suit" to misrepresent the state of affairs at the university to faculty members. ${ }^{353}$ Mistrust of the president was unmistakable in two cartoons representing Roman senators entitled "Chronicles of Old Carleton." In fact, one of these comics was printed in both the April 10 and June 1975 issues and the caption read: "When I veto something, I want it to stay vetoed! I didn't veni, vidi, vici just to have a bunch of senators mess up my program" (See Illustrations 2.1 and 2.2).

${ }^{353}$ CUASA News 5, no. 2 (December 1974): 2, FN 1, Chapter 2. 


\section{Illustration 2.1 "Shabby Suit"}

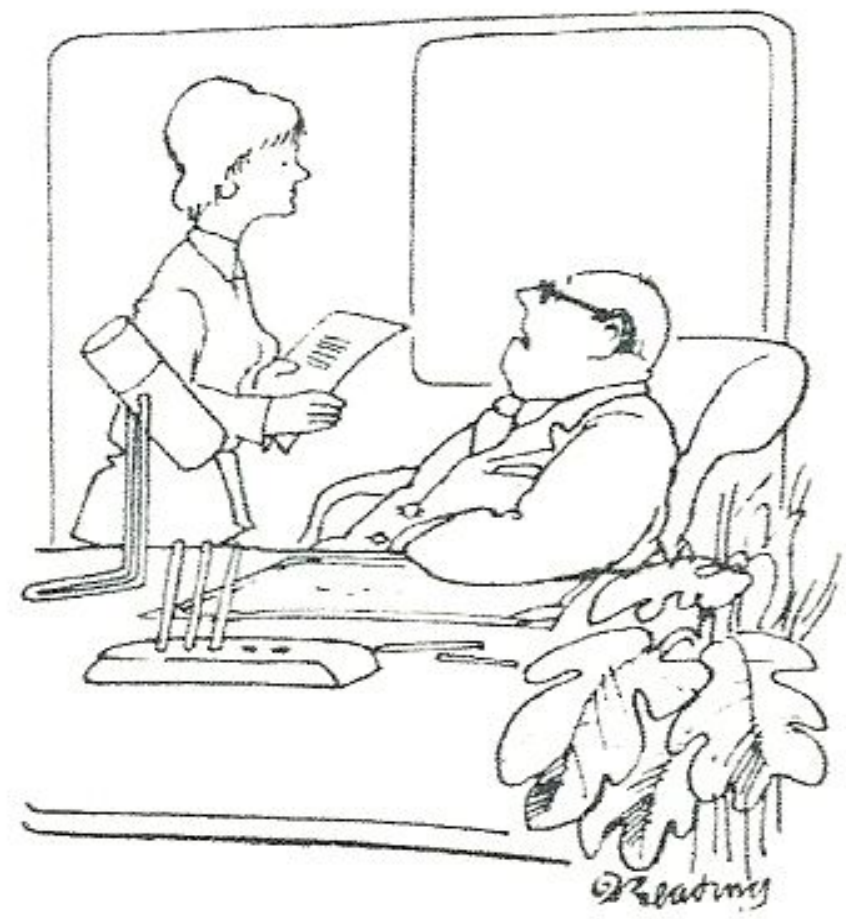

"But I can't see the strike committee today-l've left my shabby suit at home."

CUASA representatives were clearly framing President Michael Oliver as less than honest. CUASA News 5, no. 2 (December 1974): 2.

Whether the commanding figure in the image is Oliver or one representative of the corporate leaders of the university including board members of the board, the statement reflects the idea that professors had long expressed about their historical relationship with other institutional decision makers. By failing to be the self-governing community of

\section{Illustration 2.2. “Chronicles of Old Carleton": Veni, Vidi, Vici}




\section{"Chronicles Of Old Carleton"}

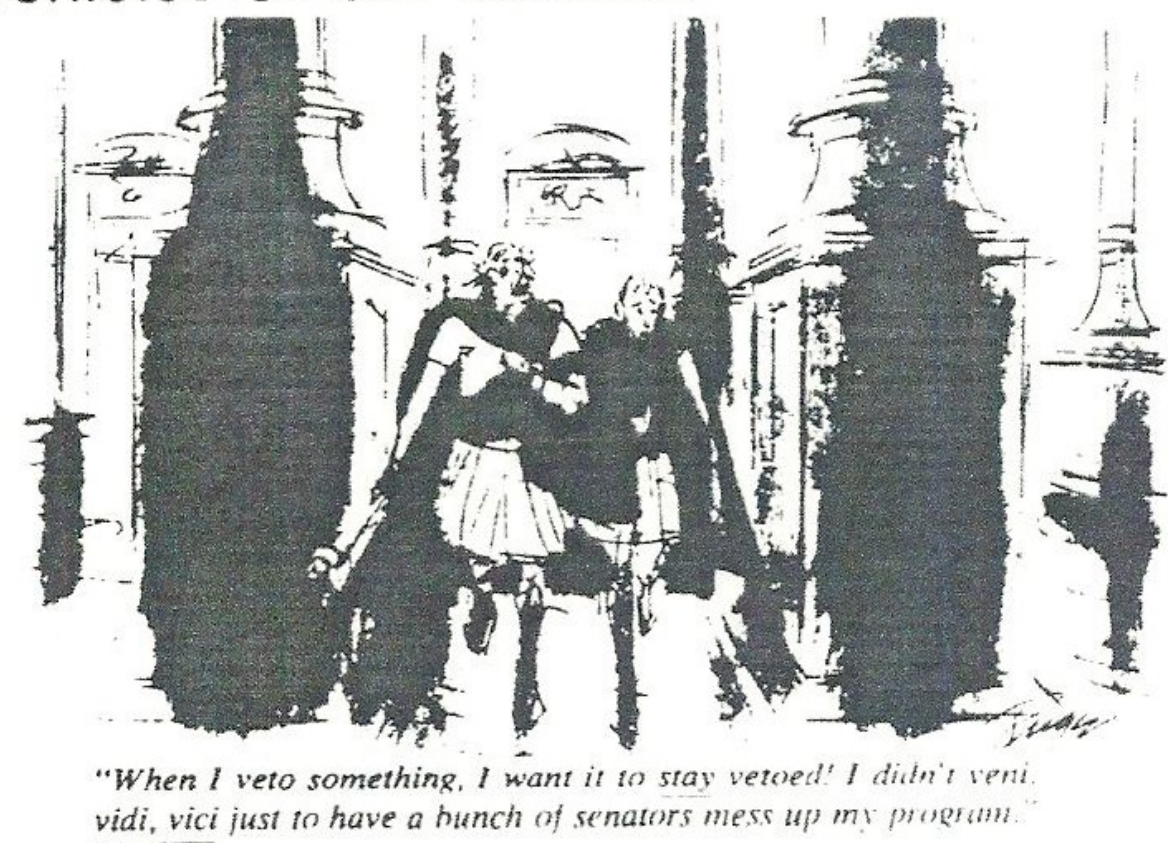

Here the "Old Carletonians," along with Oliver, are framed as being part of the problem. CUASA News 5, no. 4 (June 1975).

scholars it should be, the university left professors exposed to the arbitrary decisionmaking of others with less concern for the well-being of the institution.

In addition to the efforts of organizers to frame the issues in terms of occupational status, at least other two factors help explain the success of the certification drive. University representatives chose not to intervene actively and organizers made no overt references to gender inequality during the campaign. Interference from management can be a significant factor in the final outcome of unionization drives. In fact, as Professor J. George Neuspil wrote in the April 8 issue of CUASA News, the Labour Relations Act made specific reference to "the limits of permissible persuasion" and, in particular, stipulated that employers could not "use coercion, intimidation, threats, promises or 
undue influences. ${ }^{״ 54}$ Despite these legal requirements, CUASA volunteers feared reprisals or intimidation as they canvassed for new members, encouraged professors to cancel classes to attend the education sessions, and published their newsletter. However, such resistance proved to be unfounded, as Andrew Brook recalls: although "there's a certain amount of paranoid expectations, I mean, 'At some point we're going to get it for doing this,' but it never materialized." ${ }^{355}$ Individual deans and departmental chairs did request the names of professors who cancelled classes to attend the educational workshops, but official institutional attempts to stop unionization appear to have been minimal. ${ }^{356}$

This lack of formal resistance stemmed from a number of sources including personal preference and administrative confidence. Don McEown proposed at the time that university administrators could oppose unionization on the grounds that faculty members were already "so involved in the management of the university through the Senate and picking the president. ${ }^{, 357}$ However, the consensus among senior managers was that this strategy was not viable and, as Vice-President Love suggested in his memo to faculty on April 7, senior managers were comfortable working with the existing faculty association that already effectively negotiated on behalf of professors. ${ }^{358}$ Plus, McEown suspected that Michael Oliver's "socialist" politics made the president unwilling to "fight" the unions.

${ }^{354}$ J. George Neuspil, "This is the Law!” CUASA News Special Edition (April 8, 1975): 2, FN 1, Chapter 2.

${ }^{355}$ A. Brook, oral history.

356 "Why Collective Bargaining (II)," CUASA News Special Edition (February 5, 1975): 2, FN 1, Chapter 2.

${ }^{357}$ D. McEown, oral history.

${ }^{358}$ G.R. Love, Memorandum to all members of faculty, reprinted in This Week Times Two Special Edition (Thursday, April 10, 1975): 8, FN 3, Chapter 2. 
University administrators did express concerns publicly prior to the representation vote. In the same April 7 memo, Love questioned the appropriateness of the provincial labour legislation for academia. "I do have reservations as to whether the Labour Relations Act, designed as it is to deal with an organizational model quite different from a university, is an appropriate vehicle to impose on the governing relationships within a university. ${ }^{359}$ And Michael Oliver made his position clear in the April 8 issue of This Week Times Two. Whereas a faculty union would not threaten the "health and strength" of Carleton University, collective bargaining was not necessarily compatible with the "shared authority" that marked decision-making at universities. ${ }^{360}$ Negotiations might actually threaten the "tradition of departmental autonomy" as the "President, VicePresidents, and the Deans" could have stronger roles as a result of their "automatic locus standi" at the bargaining table. ${ }^{361}$ The release of these public statements at the same time that representation vote was held indicates perhaps a desire to influence the final decision to unionize. However, administrators do not appear to have had an overall strategy for preventing certification. Faculty chose decisively to gain the legal authority to both bargain and enter into a binding employment contract with the university.

Female faculty also held back during the certification campaign by refraining from raising the issue of workplace gender inequality. Academic work had long been the territory of men and thus masculine work. As Vickers and co-author June Adam pointed out in their 1977 monograph but can you type? Canadian Universities and the Status of Women, historically fewer Canadian women than men had pursued higher education and

${ }^{359}$ Ibid.

${ }^{360}$ Michael Oliver, "Statement from the President," This Week Times Two Special Edition (Thursday, April 10, 1975): 6 .

${ }^{361}$ Ibid. 
few became university professors. ${ }^{362}$ Those women who were employed as faculty members typically attained a lower status than their male colleagues as measured by their average rank of either assistant or associate rather than full professors and the expectation that they would teach rather than do research. ${ }^{363}$ Official institutional statistics are unavailable for the breakdown in membership in CUASA by sex but according to a 1975 report to the Ministry of Colleges and Universities, at this time only $10 \%$ of Carleton faculty members were women. ${ }^{364}$ Faced with this reality, Vickers and other campaigners chose to frame the need for unionization in terms of the interests that would appeal to the majority of CUASA members. They were careful not to draw attention to the "subagendum" of women's rights during unionization: "Oh, you don't think we told them that, did you?" Instead they focused on the "overt agenda" of job security, the collective mistrust of Michael Oliver and the "rule of law" because these issues could mobilize a broader cross-section of the faculty population including "new, younger people," and academics from a number of disciplines such as the economics department and the engineering faculty. ${ }^{365}$ This was a significant decision. The "gender agenda" had been the principal reason Jill Vickers participated actively in CUASA and the certification campaign; moreover, she had observed that it also motivated "a number of women" to be amongst the most active CUASA members "in the first decade" after unionization, including several librarians. ${ }^{366}$ As a result, although gender equality was not a highlight of the campaign, unionization was a gendered issue.

\footnotetext{
${ }^{362}$ Vickers and Adam, but can you type, 8 .

363 Ibid.

${ }^{364}$ Gail McIntyre and Janice Doherty, Women and Ontario Universities (October 1975), 125.

365 Ibid.

${ }^{366}$ J. Vickers, oral history.
} 


\section{Conclusion and Epilogue}

The OLRB made the final decision in late June that departmental chairs did not manage but worked collegially with their peers which placed them in the bargaining unit—a significant ruling, particularly in light of the 1980 Yeshiva case, in which the American Supreme Court ruled that faculty members in a private university were "managerial," thus effectively halting faculty unionization in the United States. ${ }^{367}$ Soon after CUASA representatives received the final certificate to bargain, they submitted a seventy-five-page list of proposals to the university's negotiating team: this was July 14 , "Bastille Day." ${ }^{368}$ Jill Vickers became the chief negotiator for CUASA, while board member Cliff Kelley, a "labour relations expert for the CBC management," led the university's team. ${ }^{369}$ Michael Oliver had correctly noted, in early April, that the period prior to certification had not been characterized by "the spirit of acrimony" experienced on other campuses. ${ }^{370}$ This would not be true of the negotiating process. ${ }^{371}$ For many involved, the following months would be "gruelling," with the two sides pursuing different mandates: according to Vickers, CUASA's team intended to "get us the best possible protection against exigency and to introduce the best contract with regard to the rule of law across the whole broad range of processes, but not to get a lot of money" while Kelley was expected to "bring it in cheap" and evidently found it difficult to understand that money was not the professors' first priority. ${ }^{372}$

${ }^{367}$ Robert H. Metchik and Parbudyal Singh, "Yeshiva and Faculty Unionization in Higher Education," Labor Studies Journal 28, no. 4 (Winter 2004): 45.

${ }^{368}$ Vickers, "The Wheels Grind Exceedingly Slow."

${ }^{369}$ A. Brook, oral history; J. Vickers, oral history.

370 "Statement from the President," This Week Times Two Special Edition (Thursday, April 10, 1975): 6, FN 3, Chapter 2.

${ }^{371}$ J. Vickers, oral history.

${ }^{372}$ A. Brook, oral history. 
Talks broke down in early September and although spokespersons for both the university and the association were optimistic when a new round of meetings was announced later that month, negotiations almost floundered again. Brook, who was one of the members of the CUASA team, credits Michael Oliver with facilitating a positive outcome in early November. ${ }^{373}$

Well, we'd been going at it and going at it and going at it, and the chief negotiator for the university ... had fairly strict marching orders from the board about how far he could go, and we just weren't living with what he was offering us. So we pretty much reached an impasse. And in a fit of desperation ... one of our team called Michael Oliver and said, "You've got to intervene, this is just going nowhere." And so he invited both sides over to his house, put a bottle of scotch on the coffee table, and said, "I'm going to bed." And [at] about three that morning, we had an agreement. ${ }^{374}$

On November 14, professors voted to ratify the agreement and by December 11, 1975 the board had signed the agreement. ${ }^{375}$ CUASA members now had their legally binding employment contract and although Kelley had been "a pretty tough cookie,"376 Vickers thinks that the professors "gained a great deal from having a professional on the other side" and the contract provided them with improved working conditions including an $18 \%$ salary increase, better fringe benefits such as a dental plan and a tenure appeal committee. $^{377}$

In Scholars and Dollars, Paul Axelrod concludes that Carleton organizers led a successful certification drive because they "upheld academic traditions and university

${ }^{373}$ Ben Pederson, "Faculty Talks on Again," The Charlatan 5, no. 7 (Friday, September 26, 1975): 1; Ben Pederson, "Faculty to Ratify Agreement," The Charlatan 5, 14 (Friday, November 14, 1975): 7. Note: All issues of The Carleton and The Charlatan (Carleton University's student newspaper) are located in Archives and Research Collections at the Carleton University Library. As such, this information will be cited only once, in this footnote. All future citations will refer back to FN 373, Chapter 2.

${ }_{374}$ A. Brook, oral history.

${ }^{375}$ Ben Pederson, "Faculty Contract off to Anti-inflation Board," The Charlatan 5, 20 (Friday, January 23, 1976), FN 373, Chapter 2.

${ }^{376}$ A. Brook, oral history.

${ }^{377}$ Pederson, "Faculty to ratify agreement," FN 373, Chapter 2. 
conventions" rather than threatening the status quo. ${ }^{378}$ Certainly, those leading the unionization campaign did frame collective bargaining as a tool that could protect the status of professors and, with the "rule of law," faculty members were able to negotiate an inaugural contract that provided distinct material benefits and gave them greater power over some decision-making processes such as grievance resolutions. ${ }^{379}$ In addition, the decision to certify their existing faculty association rather than join an external union such as CUPE was significant in terms of occupational identity. Many faculty were not interested in aligning with the trade union movement, given its historical connection with industrial workers. Instead, they preferred to belong to an independent, self-governing association that was effectively more consistent with the academic tradition of collegial self-governance and their identity as "the university" and not employees. For example, the CUASA negotiating team consisted of Carleton professors who might take input and advice from representatives of faculty-affiliated groups such as CAUT but ultimately bargained on behalf of the interests of their members and were not led by anyone outside of CUASA.

Certification also upheld another tradition that was meaningful not only for faculty but also to other Carleton employees: the relative positioning of faculty within the campus occupational hierarchy. As Rosabeth Moss Kanter argues in her classic 1977 study Men and Women of the Corporation, by the mid-1970s many North Americans were working in white-collar jobs at either private or public organizations modelled to

\footnotetext{
${ }^{378}$ Axelrod, Scholars and Dollars, 210. In his analysis of faculty unionization at Carleton, Axelrod draws on Debra Mair's thesis on the unionization of Carleton faculty. Mair does not use either status or gender to analyze the union drive whereas this study reveals the critical role that both played in the success of the certification drive.

${ }^{379}$ Power is a highly contested theoretical concept. I am using Peter Morriss's definition of power: "the ability to act and thus effect outcomes." Peter Morriss, Power. A Philosophical Analysis, $2^{\text {nd }}$ ed., (New York: Manchester University Press, 2002).
} 
some extent after the corporation. ${ }^{380}$ In these large bureaucracies, work was broadly divided into discrete areas of responsibility based on organizational need and employees usually worked in offices where jobs were arranged hierarchically according, in large part, to the level of institutional power assigned to each position. At the "top" of the organization (or a given office) were the "managers, professionals and technical personnel" who had the greatest power; at the bottom were the "paper handlers" with little if any control over resources. ${ }^{381}$ Carleton University was not only legally a corporation but also operationally a large bureaucracy with its own particular occupational structure; as Don McEown observed, "the whole social strata of the university is a complex piece of business. ${ }^{, 382}$ Some professors may have viewed themselves as working outside the existing hierarchy but other employees did not and frequently perceived faculty as occupying the upper rung of the job ladder; certainly this true of librarians and support staff who unionized in the same period and whose decisions to vote in favour of certification was directly influenced by their status relative to faculty. Support staff in particular recognized that the legal right to collective bargaining provided faculty with greater decision-making power and threatened to widen the status gap between non-academic staff and professors who now had "more clout"relatively and absolutely. ${ }^{383}$

In retrospect some union leaders question the long-term impact of collective bargaining. Prior to certification, Andrew Brook's experience was undoubtedly shared by many faculty members: "management made all the decisions, had all the power, and we

${ }^{380}$ Rosabeth Moss Kanter, Men and Women of the Corporation (New York: BasicBooks, 1993 edition), 3 .

${ }^{381}$ Ibid., 4.

${ }^{382} \mathrm{D}$. McEown, oral history.

${ }^{383}$ MacRae, in oral history. 
had no idea how they were being made, we had no idea who's benefitting and we had no say.” After certification, he found that, as a group, professors had a greater capacity to safeguard "individual rights" and adjudicate conflicts related to key employment conditions such as tenure in part because of their right to strike. In addition, he thinks that “finances are just way more transparent and senior administrators are much more accountable." However, he also believes that over time the process of negotiation at Carleton became "pretty dysfunctional ... everything is rammed up to the 11 th hour and each party squeaks until each side collapses a little bit, which is not good for collective agreements" and, as a result, professors have not achieved a significantly greater role in university administrative decision-making. ${ }^{384}$

Certification also resulted in some improvement in the status of female faculty members to some extent. Jill Vickers led CUASA's first negotiating team and although she acknowledges that there were "some bad deals and some things in retrospect I feel embarrassed about" in general, she is still pleased that she was able to take "what I could for my women." 385 For example, the team managed to bring a number of female sessional instructors into the bargaining unit who were "full time under the labour code and ... were being exploited" and signed a memorandum of understanding that ensured that no requests for maternity leave could be "reasonably denied." In addition, she believes that CUASA itself has been a relatively "women-friendly" organization, that is to say an institution in which women have participated actively in the founding of and have a

\footnotetext{
${ }^{384}$ A. Brook, oral history.

${ }^{385}$ J. Vickers, oral history.
} 
continuing presence and therefore some "clout." ${ }^{, 386}$ As a political scientist, Vickers has specialized in studies of gender and democracy and found that,

Very few organizations are women-friendly ... unless they were created by women in fairly equal roles ... [however] CUASA ... I think stayed a womenfriendly space because we were there, in on the ground floor, we had a feminist agenda, there had been an awful lot of women who had served as president and chief negotiator and all of that. ${ }^{387}$

With women taking leadership roles in the union, gender issues did not "fall off the table" as it did in other organizations, even if core benefits such as maternity leave were not included in the initial contract. ${ }^{388}$

Status and gender thus played significant roles in the decision by Carleton University faculty members to support, oppose and ultimately vote in favour of unionization. And, as will be demonstrated in the following chapters, these social constructs were also key factors in the success of the efforts of librarians and support staff to organize.

${ }^{386}$ Jill Vickers, "What Makes Some Democracies More 'Women-Friendly'?” Canadian Political Science Association, accessed September 26, 2013, http://www.cpsa-acsp.ca/papers-2006/Vickers.pdf.

${ }^{387} \mathrm{~J}$. Vickers, oral history.

${ }^{388}$ Ibid. 


\section{Chapter 3 A "Honey" of a Union Deal: The Labour Action of Carleton University Librarians}

\section{Introduction}

When the small group of Carleton University librarians began to think about becoming part of a formal bargaining unit in the fall of 1974, they knew that one option was to join a union that would include all non-managerial library employees. ${ }^{1}$ Retired Carleton librarian Susan Jackson believes that this was not a viable option for anyone, except perhaps the chief librarian Geoffrey Briggs, because "his idea was that he would have a honey union of all the library staff and that he would of course then have some nice influence on." If Jackson and her colleagues were going to unionize, their goal would be to gain more authority over terms and conditions of work for themselves, not the chief librarian. Plus, as former Carleton librarian Valerie Swinton recalls, they were professionals and wanted to be recognized for the "degreed" nature of their work rather than to be mistaken for employees who had "high level clerical" jobs not substantively different from other library staff - a perennial problem in an occupation that had been feminized since the late $19^{\text {th }}$ century. ${ }^{3}$ After much soul searching, the decision was made: "we discussed CUPE, we discussed CUASA, we discussed this PIPSC kind of

\footnotetext{
${ }^{1}$ Mudge, "Collective Bargaining of Librarians," 94.

${ }^{2}$ S. Jackson, oral history.

${ }^{3}$ Valerie Swinton in oral history interview with the author, May 30, 2011. Although Swinton's last name was McDougall at the time of unionization, her current last name will be used for this analysis except in footnotes and the bibliography where all documents authored by her in the 1970s will be cited using McDougall. Her attitudes are consistent with those noted by Carl Garry in the overview of the opinions of Canadian professional librarians on unionization in his Chapter, "The Unionization of the Profession," in Canadian Libraries and Their Changing Environment, eds. Lorraine Spencer Garry and Carl Garry (Toronto: York University, Centre for Continuing Education, 1977), 499-501. Garry notes that librarians had "an anathema for unionization which was regarded as working class." See Chapter 1 of this thesis for the definition of the process of feminization.
} 
organization and decided that really our interests were more allied to the academic group", that belonged to the Carleton University Academic Staff Association (CUASA).

Less than a year after their initial conversations about a more collective approach to negotiating working conditions, Carleton librarians struck their own "honey" of a union deal in the summer of 1975. Earlier in February, CUASA council members had quietly voted to admit librarians into the faculty association. As a result, four months later the majority of Carleton librarians became founding members of the first certified faculty association in Ontario when the Ontario Labour Relations Board (OLRB) made its final ruling in favour of the Carleton University Academic Staff Association (CUASA) as the sole bargaining agent for Carleton faculty members. This was a significant change for the librarians - most of whom were women. They now had the legal right to bargain more equitable terms and conditions of work as members of the largest employee group on campus and, as we have seen in Chapter 2, they had partnered with faculty members who were also disinterested in becoming members of a trade union like the Canadian Union of Public Employees (CUPE). In addition, the librarians could distinguish themselves more easily from non-professional library staff if they were formally part of a separate, distinct and male-dominated occupational group; membership in CUASA would minimize the

\footnotetext{
${ }^{4}$ S. Jackson, oral history. In 1975, CUPE represented 91.3\% (thirty-one of thirty-four) of workers at unionized Canadian public university libraries and 47.6\% (10 of 21) of workers at the unionized Canadian university libraries. Not all of these bargaining units contained professional librarians. According to CUPE, it was one of six organizations representing professional librarians working at Canadian universities and it had locals on three campuses: University of Quebec (Montreal), Yarmouth Western Regional Counties and Bathurst College. Canadian Union of Public Employees (hereafter CUPE), Research Department, Background Material Prepared for the Institute of Professional Librarians of Ontario Panel on Job Security for Librarians (CUPE: 1975): 1-3. PIPSC is the Professional Institute of Public Servants of Canada.
} 
"feminized" stigma attached to librarianship, and strengthen the claim that their work was academic and professional, if not masculine, work. ${ }^{5}$

The purpose of this chapter is to explore how this process of unionization unfolded as it did for librarians at Carleton. It can be argued that while this collective action had its roots in the professional culture nurtured by Hilda Gifford, Carleton's first chief librarian, the librarians were mobilized largely by a desire for equity in the workplace, a goal they shared not only with Carleton faculty but also with Carleton support staff as well as other librarians in both Ontario and Canada. ${ }^{6}$ Between the spring of 1973 and June 1975, the librarians organized, first by establishing their own voluntary association and then by successfully arguing that they shared a "community of interest" with Carleton professors. Perhaps surprisingly, the inclusion of professional librarians in the Carleton faculty union was achieved with little conflict amongst individual librarians and with minimal resistance from professors or university administrators including Geoffrey Briggs. This is due, in part, to the fact that the librarians' efforts to align themselves with faculty took place at a time when the occupational status of librarianship was being actively debated in several arenas and, in particular, when the Canadian Association of University Teachers (CAUT) was publicly supporting both faculty unionization and academic status for librarians. The lack of dissent can also be attributed to two other critical aspects of the faculty union drive: the strategy of university administrators, including President Oliver, not to obstruct the CUASA certification drive; and, the decision of librarians not to frame unionization as a gender issue, even though

\footnotetext{
${ }^{5}$ See Goode, "The Librarian: From Occupation to Profession?," 306-20. According to Goode, "Librarians have complained that the public does not see the difference between the professional librarian and the non-professional, or clerk, because in the main the book-seeker has direct contact only with the latter. Perhaps some two-thirds of library work is non-professional in character."

${ }^{6}$ To be discussed in Chapter 4 of this thesis.
} 
the librarians had powerful supporters within the CUASA council, including Jill Vickers, who was particularly sensitive to what she has called the "feudal" working conditions for female library professionals. ${ }^{7}$ Once again, gender and status were critical factors in the labour activism of Carleton white-collar employees.

\section{Hilda Gifford and Early Recognition for Librarianship at Carleton (1948-1968)}

Carleton University president W.E. Beckel wrote to the university's retired chief librarian Hilda Gifford on September 10, 1982, and in a short but sweet message, he informed her that members of Senate had voted to award her an honorary Doctor of Literature honoris causa: "In recognition of your leadership, over thirty-three years, in transforming the modest book collection of a small college into the larger holdings and sophisticated library operation appropriate to the Carleton of today." "Miss Gifford"-as she is still known to former colleagues in 2014 - responded with a handwritten note that expressed both her gratitude and reservations regarding the honour:

I am deeply appreciative of the invitation ... Sadly, I face the prospect of the ceremony with some trepidation for I am a person without personal ambition or desire for formal recognition ... I personally had the continuing good fortune to believe wholeheartedly in the importance of a good library to a university, so my work often brought its own rewards. ${ }^{9}$

This brief exchange suggests that by the second half of the $20^{\text {th }}$ century, university librarianship was recognized as both academic and professional in nature. As Gifford explained in an article published in the Royal Architectural Institute of Canada Journal in 1959 , librarians in previous centuries had acted as the gatekeepers for libraries that

\footnotetext{
${ }^{7}$ J. Vickers, oral history.

${ }^{8}$ W.E. Beckel to Hilda Gifford, September 10, 1982, Public Relations and Information Services Fonds, 1996-97, PINFO-28, Fall Convocation, November 7, 1982, Hilda Gifford File, Carleton University Library Archives, Ottawa, Ontario.

${ }^{9}$ Hilda Gifford, note to W.E. Beckel, received September 7, 1982, Public Relations and Information Services Fonds, 1996-17, PINFO-28, Fall Convocation, November 7, 1982, Hilda Gifford File, Carleton University Library Archives, Ottawa, Ontario.
} 
were designed and organized, mainly to preserve book collections that remained locked away in shelves, closed to most readers and not widely circulated widely. ${ }^{10}$ She believed that this work was a "far cry" from that of the modern librarian, who was expected to have the authority and sophisticated knowledge to develop and administer library holdings that were "good", held on "open stacks" or shelves accessible to readers and integral to the teaching and research being done by faculty and students on campus. Gifford and her colleagues had a duty to bring "readers and books together in the closest possible relationship."11

"Modern" librarianship had emerged as a distinct occupation in North America in the late $19^{\text {th }}$ century as a new generation of librarians began to gain control over the field by identifying their work as professional and educational in nature. ${ }^{12}$ Promoting this enhanced role were advocates such as American librarian Melvil Dewey, who proclaimed in the first issue of The American Library Journal, published in 1876, that:

The time has at last come when a librarian may ... speak of his occupation as a profession ... The time was when a library was very like a museum, and a librarian was a mouser in musty books ... The time is when a library is a school, and the librarian is in the highest sense a teacher, and the visitor is a reader among the books as a workman among his tools. ${ }^{13}$

${ }^{10}$ Hilda Gifford, "Function and the Library Building," Royal Architectural Institute of Canada Journal 36, no. 4 (April 1959):104.

${ }^{11}$ Ibid.

${ }^{12}$ Wilensky, "The Professionalization of Everyone?" For contrasting view of professions, see also Andrew Abbott, The System of Professions. An Essay on the Division of Expert Labor (Chicago and London: The University of Chicago Press, 1988).

${ }^{13}$ Melvil Dewey, "The Profession," The American Library Journal 1, no. 1 (September 1876): 5-6. Melvil Dewey died in on December 26,1931 and according to the lengthy obituary that appeared in the New York Times the next day, he was a "an internationally known educator, inventor of the decimal classification system and spelling reform advocate." In addition to creating the decimal-based book classification system and catalogue system, he was the chief librarian at Columbia University in the late $19^{\text {th }}$ where he founded the first American library school. Latterly, he directed the New York State Library. "Dr. Melvil Dewey Dead in Florida: Noted Educator, Library Expert and Founder of Lake Placid Club Stricken at 80," New York Times, December 27, 1931 (online version), 36. http://bit.ly/18rXxpH, accessed November 30, 2013. Note: the original URL for this online document was over six lines in length. For simplicity, this is the Bitly version of that link. 
While Dewey seemed to be singling out men for professional librarianship, he publicly supported the entry of women into the profession, and both men and women were engaged in the early "library movement" in and Canada and the United States. ${ }^{14}$ These pioneers quickly recognized the need for a collegial professional community and formed two occupational organizations, the American Library Association (ALA) in 1876 and the Ontario Library Association (OLA) in 1900, through which they communicated and collaborated regularly with each other at their respective annual conferences, committee meetings and in their organizational journals, The American Library Journal and the Ontario Library Review. ${ }^{15}$

OLA members had an ambitious programme for their "missionary work." ${ }^{\text {16 }}$ One of their principal goals was to regulate the profession by developing library standards that included specialized training because, as E.A. Hardy, the secretary of the Lindsay Public Library, stated in 1901, "Skilled workmanship is everywhere in demand and library work should be under the direction of trained librarians. ${ }^{17}$ The first North American library

\footnotetext{
${ }^{14}$ Melvil Dewey, "Women in Libraries: How They are Handicapped," reprinted in The Role of Women in Librarianship 1876-1976, eds. Weibel and Heim, 10-2. In this seminal article, Dewey advocated for librarianship as a suitable occupation for women but believed that they would be "handicapped" due to lack of physical stamina, lack of appropriate business training and the temporariness of their participation in the paid labour force, i.e., librarians were expected to be single and then to leave their paid employment when they married.

${ }^{15}$ Dewey, "The Library Profession," 22. In Canada there was discussion amongst librarians in 1900 of forming a national Canadian organization. However, despite efforts over the next four decades, the Canadian Library Association was not established until 1946. The OLA was the only Canadian library association until 1919 when another was formed in British Columbia. There was considerable collaboration between American and Canadian librarians. For example, four ALA conferences were held in Canada between 1900 and 1934: Montreal (1900 and 1934), Ottawa (1912) and Toronto (1928). Elizabeth Homer Morton, "The Canadian and American Library Associations," ALA Bulletin 54, no. 4 (April 1960): 283-85. Likewise, the ALA formed the Canadian Library Council in June 1934 to address issues of importance to its Canadian members. Hon. H.H. Stevens, Minister of Trade and Commerce, Survey of Libraries in Canada 1933, (Ottawa: 1933), 14.

${ }^{16}$ Judge [E.A.] Hardy, "Presidential Address. The Proceedings of the Ontario Library Association, Tenth Annual Meeting, March 28 and 29, 1910,” (Toronto: Legislative Assembly, 1910), 33.

${ }^{17}$ E.A. Hardy, "An Outline Programme of the Work of the Ontario Library Association. A Paper Read at the First Annual Meeting, 1901," reprinted in The Ontario Library Association, The Ontario Library Association. An Historical Sketch. 1900-1926 (Toronto: University of Toronto Press, 1926), 26.
} 
schools were founded in the United States in the late 1800s and emphasized technical skills such as classification and cataloguing. ${ }^{18}$ Canadians could, and did, attend these schools, but from the early 1900s they also had the option of taking "intensive" three- or four-week summer courses offered at McGill University (1904) and with the Ontario Ministry of Education (1911), in addition to those offered at several large Ontario public libraries such as the Toronto Public Library. ${ }^{19}$

Despite efforts to set standards and regulate the profession during the early $20^{\text {th }}$ century, North American librarianship was plagued by a lack of recognition that lowered its occupational status. Librarians realized that they continued to be as "ill paid" 20 as they had been in the $19^{\text {th }}$ century, and they were keenly aware that their work was not perceived as skilled or expert. In a 1922 opinion piece on the recruitment of academic librarians, W.E. Henry, the chief librarian at the University of Washington, summed up these frustrations. Not only were wages lower than those paid for similar or competing occupations but the role of library work in education was misunderstood because most library users defined librarianship narrowly in terms of the service offered at the "lending desk"- everyone could be a librarian. ${ }^{21}$ Henry was convinced that the root cause of these problems was the feminization of modern librarianship.

Our profession has come to be looked upon as a women's profession, not only for the large per cent of womanly women engaged in it, but also and quite as much as

\footnotetext{
${ }^{18}$ Charles C. Williamson, "Training for Library Work, 1921," reprinted in The Williamson Reports of 1921 and 1923 (Metuchen, New Jersey: Scarecrow Press Inc., 1921), 21-29.

${ }^{19}$ Students of the School, "The Training School for Librarianship," Ontario Library Review II, no. 2: 53. Similar library-based training programs were also available in the United States during this period. See for example, Barbara Brand, "Pratt Institute Library School: The Perils of Professionalism," in Reclaiming the American Library Past: Writing the Women In, ed. Suzanne Hildebrand (Norwood, New Jersey: Ablex Publishing Company, 1996), 251-78.

${ }^{20}$ Editorial, The American Library Journal 1, no. 1 (September 30, 1876): 12.

${ }^{21}$ W.E. Henry, "Recruiting for College and University Libraries," Bulletin of the American Library Association 16, no. 4, Papers and Proceedings of the Forty-Fourth Annual Meeting of the American Library Association (July 1922): 125.
} 
because of the large per cent of lady-like men that are numbered within our ranks. Can anything be done ... so that a larger number ... of the strongest and best of both men and women may come into our profession and vitalize it with ... a greatly augmented manly and womanly energy? ${ }^{22}$

Whether Henry was right (i.e., that many librarians were lady-like) or not, the majority of library staff in North America was female during this period. Library work, along with other occupations such as nursing, teaching and social work, had been culturally sanctioned as appropriate paid work for young, single women. ${ }^{23}$ Many women had entered the field in both Canada and the United States between the late 1880s and early 1920 s, even though, as "women's work," the pay was relatively poor. ${ }^{24}$

B. Mabel Dunham, the chief librarian for the Kitchener Public Library (19081944) and OLA president in 1920, was equally dissatisfied with the state of librarianship. ${ }^{25}$ Her presidential address, delivered two years before Mr. Henry published his polemic, bluntly stated that, "library work in Ontario at least, is called a profession by courtesy only. ${ }^{26}$ She was specifically incensed about the status of public library work and although she too associated the lack of prestige with the presence of women, she also blamed it on the presence and decision-making of men. According to Dunham, the 1920s were certainly a time when women played a greater public role, particularly in the workplace. No longer was it accepted, even by the "most confirmed woman-hater," that women should be relegated to the home sphere-women had the right to be "engaged in all manner of occupations once sacred to the lords of creation., ${ }^{27}$ However, while librarianship was a suitable occupation — if not a vocation—for women and especially

\footnotetext{
${ }^{22}$ Ibid.

${ }^{23}$ See for example, Milner, “'Lady Librarian'," and Garrison, "The Tender Technicians."

${ }^{24}$ Ibid.

${ }^{25}$ The Ontario Library Association, An Historical Sketch, 57.

${ }^{26}$ B. Mabel Dunham, "Library Work as a Profession for Canadian Women," 2, (OLA Presidential Address), Ontario Library Association fonds, MV 2246, F1195, Archives of Ontario, Toronto, Ontario.

${ }^{27}$ Ibid., 1.
} 
university-educated women, the field was suffering in part because chief librarians were often men who

drifted into the profession from many other walks in life and they hold their positions, like our judges, for life and good conduct. They are for the most part managers of large libraries and are surrounded by a corps of assistants who are either trained or experienced workers in the various departments of library service. $^{28}$

Dunham found that librarianship at that time was also less professional because the assistants could often be untrained women who were hired by the local library board and held jobs in their hometowns for life. In either case, university-educated women found it difficult to get a professional "footing." 29 The real culprits responsible for the present state of the profession were ignorant and apathetic male-dominated library boards that were disinterested in improving hiring practices or helping to develop professional standards such as those that existed for medicine, law, nursing and teaching.

Library movement leaders considered a number of solutions to this problem of low status such as improved compensation standards and educational reform. In the late 1920s the ALA's own Committee on the Classification of Library Personnel received proposals from the American Bureau of Public Personnel Administration for a set of universal job classifications and pay scales based on the principle of "equal pay for equal work." ${ }^{30}$ According to the Bureau's final report on job classifications and pay scales to this committee, these changes were necessary to improve compensation for librarians, most of whom were highly intelligent women, underpaid relative to workers in other

\footnotetext{
${ }^{28}$ Ibid., 2

29 Ibid.

${ }^{30}$ Bureau of Public Personnel Administration, Proposed Classification and Compensation Plans for Library Positions. Report of the Bureau of Public Personnel Administration to the Committee on the classification of Library Personnel of the American Library Association (Washington, DC: Bureau of Public Personnel Administration, 1927), 22. There is no evidence to indicate whether the ALA committee solicited this work from the Bureau or not. See Chapter 4 of this thesis for a discussion of the use of the Hay job classification for administrative and technical workers at Carleton in the mid-1960s.
} 
occupations such as clerks, stenographers, skilled tradesmen and even "the janitor who merely keeps the room clean and orderly., ${ }^{, 31}$ The report included suggested pay scales for all sectors and those for college and university chief librarians ranged from $\$ 1,860$ to $\$ 7,500$, depending upon the number of library employees (i.e., whether the library was considered smaller or larger). ${ }^{32}$

More popular than higher payroll expenditures, however, were recommendations to reform library education. ${ }^{33}$ Based on the 1921 Williamson report entitled Training for Library Work. A Report Prepared for the Carnegie Corporation of New York, library educators in both Canada and the United States began to revise their programs in the 1920s. Charles E. Williamson believed that programs needed to be university-based, accredited and adopted by the "by the proper professional body" (i.e., the ALA). ${ }^{34}$ Curricula should be developed for year-long programs and include both technical and cultural material as library work was not "wholly clerical in nature" or routine in nature; instructors were to be classed as academic staff. ${ }^{35}$ These changes, modelled after the programs offered in the traditional professions such as law and medicine, were intended to improve professional standards as well as the reputation of library schools within the academic community where respect was currently lacking, in part, because of the lack of men and the "preponderance of women in both faculty and student body."36

The Canadian library community responded positively to the idea of educational reform and, by the early 1930s, students could earn a one-year Bachelor of Library

\footnotetext{
${ }^{31}$ Ibid., 20.

${ }^{32}$ Williamson, "Training for Library Work," 57-58.

${ }^{33}$ Establishing educational credentials has traditionally been a key component of the process of professionalization. See for example, Tracey L. Adams, "Professional Regulation in Canada: Past and Present," Canadian Issues (Spring 2007), 14-16; also Wilensky, "The Professionalization of Everyone?"

${ }^{34}$ Williamson, "Training for Library Work, 1921," 79, 28 and 32.

${ }^{35}$ Ibid., 25, 23 and 32.

${ }^{36}$ Ibid., 71 .
} 
Science (BLS) from the ALA-accredited McGill University library school, or take a oneyear program at the Ontario College of Education in Toronto. ${ }^{37}$ However, despite a 1946 federal government official statement that confidently claimed that a librarian was now an "educationist" rather than a "glorified file clerk ... a curator of books,", librarians continued to struggle for occupational legitimacy. Salaries were persistently low compared to those of other occupations such as teaching, ${ }^{39}$ and predominantly single women still flocked to library schools while men did not, although they were expected to have better career opportunities than women given the gendered occupational hierarchy. ${ }^{40}$ Within the field, women generally earned less than men, even those with considerable experience, and they faced a "double ghetto" in that men were more likely to be promoted into senior management positions. ${ }^{41}$ Between 1936 and 1938, of the 199 fulltime librarians in Canadian university, college and professional libraries who reported their income, all of those in the highest salary bracket were men while female librarians dominated the lower salary categories. ${ }^{42}$ Moreover, salaries at academic libraries continued to be lower than those at public libraries, and in small academic libraries (e.g., those for normal schools) wages trailed behind those at larger colleges and universities. ${ }^{43}$ Women held the majority of chief librarian positions in these smaller (and most often less prestigious) institutions.

\footnotetext{
${ }^{37}$ Canada, Survey of Libraries in Canada 1931 (Ottawa: Department of Trade and Commerce, Dominion Bureau of Statistics, 1933), 23. Note: All these surveys were published by the Dominion Bureau of Statistics. Subsequent footnotes will not contain this information,

${ }^{38}$ Canada, Survey of Libraries in Canada 1942-44, (Ottawa:, 1934), 20.

${ }^{39}$ Ibid., 35.

${ }^{40}$ Canada, Survey of Libraries in Canada 1935, (Ottawa:, 1933), 56. See also Jean Weihs, "Women in Libraries: The Long Struggle for Equality," Interfaces 28, no. 3 (May/June 2008): 11.

${ }^{41}$ Armstrong and Armstrong, The Double Ghetto.

${ }^{42}$ Canada, Survey of Libraries in Canada 1936-38, (Ottawa:, 1933), 30.

${ }^{43}$ Canada. Survey of Libraries, 1946-48, 19.
} 
In August 1948, Hilda Gifford arrived at Carleton College with the credentials, aspirations and challenges of her generation of academic librarians. Raised in Montreal, where her father was a history professor ${ }^{44}$ at McGill University, she completed her Bachelor of Arts in 1937 and then her one-year Bachelor of Library Science in $1938 .^{45}$ Gifford never regretted taking her mother's advice to enrol in a "librarian's course," which included topics such as "the history of books, public relations, planning a library building"- useful training as it turned out. ${ }^{46}$ Over the next ten years, perhaps because she was a person of "wide intellectual interests" with a taste for travel, ${ }^{47}$ or due to the lack of available jobs in Canada, ${ }^{48}$ Gifford worked mainly as a cataloguer at several university libraries including Dalhousie University, Harvard Law School and Dartmouth College. ${ }^{49}$ Gifford's appointment as the chief librarian for Carleton College was unusual. Women dominated the profession in both Canada and the United States and if they held positions as chief librarians, they were typically working at small libraries. Gifford might have seemed to fit that occupational stereotype but, as we have seen in Chapter 1, H.M. Tory always intended that Carleton was to be a university and he was determined that even in its early years, the school would offer a library collection to support the work of students

\footnotetext{
${ }^{44}$ Newspaper clipping (no title), Public Relations and Information Services, AC. No. 1996-17, Former employees 1954-1994, PINFO-36, Gifford, Hilda, 1948-82, Carleton University Library Archives.

${ }^{45}$ Kathryn Hubbard, e-mail message to author, April 25, 2012.

${ }^{46}$ Newspaper clipping (no title). See also Canada, Survey of Libraries 1948-1950 and Survey of Libraries 1948-50 (Ottawa: Edmund Cloutier, 1952), 29. Training included 30 semester hours and obligatory courses included organization and administration of libraries, acquisition and care of library materials, selection and use of library materials, and library practice as an educational factor in society.

${ }^{47}$ David Farr, unpublished tribute to Hilda Gifford, 1, Library Historical Collection, Hilda Gifford File, A294 2004-17, Carleton University Library Archives, Ottawa, Ontario.

${ }_{48}^{48}$ Blackburn, Evolution of the Heart, 302.

${ }^{49}$ Carleton University Library, Carleton Library Staff. Newsletter no. 2 (December 1973): 1, Library Historical Collection, Carleton Library Staff Newsletter 1973-1974, LSC-040 2009-42, Carleton University Library Archives, Ottawa, Ontario; Ibid. The name of this school was spelled Dartmourt in the newsletter but this could be Dartmouth College in New Hampshire. "Carleton librarian runs big business," Ottawa Citizen, May 27, 1968, AC. No. 1996-17, Former employees 1954-1994, PINFO-36, Gifford, Hilda, 1948-82, Carleton University Library Archives, Ottawa Ontario.
} 
and faculty. ${ }^{50}$ As a result, Gifford was effectively hired to oversee the development of a large academic library and over the course of her twenty-year tenure as chief librarian, she had enough support from senior college administrators to plan the library buildings, collections and staff to be the "heart of the academic community." 51 She was fulfilling Dewey's visions of the library as a school and the librarian as a teacher.

Gifford assumed responsibility for the library at Carleton's original First Avenue campus, which was located in the former Ottawa Ladies College in Ottawa's middle class neighbourhood called "The Glebe.",52 The collection consisted of a relatively small collection of approximately 4,000 books (mostly donations), some periodicals and catalogue cards typed by the bursar's secretary since the early 1940 s but not much else. ${ }^{53}$ The lack of existing resources and infrastructure gave her great freedom to design the first college library building, and apparently she had "a very firm idea of what she wanted the library to be, she had developed it from scratch. It was her beloved child." ${ }^{, 54}$ By December 1950, she was overseeing the move into a "spacious new library" that cost $\$ 89,000 .^{55}$ The building reflected her thinking about librarianship and was in the best tradition of the reformists of the former half century: adequate workspaces for staff to free up time to provide reference assistance, as well as enough shelves for an expanding

\footnotetext{
${ }^{50}$ A review of the Board minutes for the Ottawa Association for the Advancement of Learning from 1942 to 1948 (the year Gifford was hired) reveals that Tory accepted all book donations, assigned staff to process and organize the materials and even established a library committee in 1945 to take staff requests for reference and other materials.

${ }^{51}$ Farr, unpublished tribute, 3. Hiring a professional librarian and allocating resources for acquisitions, staff and a new building indicates institutional support for the college library.

${ }^{52}$ Neatby and McEown, Creating Carleton, 25.

53 “Humble Beginnings," Carleton Library Staff Newsletter, 1 (Nov. 1973): 1, Library Historical Collection, LSC-040 2009-42, Carleton University Library Archives.

${ }^{54}$ S. Jackson, oral history.

55 Jim Muir, "Spacious Library to Open Soon," The Carleton 10 (Thursday, December 7, 1950): 6-7, FN 373, Chapter 2; Carleton College, Report and Financial Statement for the Year Ended June 30, 1950, Cover letter: 1, Office of the Vice President (Planning and Development) fonds, OCPPD-48, 30/06/50, Carleton University Corporate Archives, Ottawa, Ontario.
} 
collection that by then contained enough volumes for students to do their work without depending "on outside libraries"; ${ }^{56}$ designated areas or rooms for reading and studying as well as the consultation of less frequently used materials; and most importantly an openshelf system that gave patrons the opportunity to actually look at books before choosing to sign them out. ${ }^{57}$ The library would be "a definite help to all students." many of the same principles, this time with the direct advice of Harvard's former librarian Keyes D. Metcalf, to the construction of the much larger, multi-million dollar Maxwell MacOdrum Library, which opened nine years later, on Carleton's new Rideau River. $^{59}$

If the library was the heart of the university, the collection was its lifeblood. Gifford had inherited materials from donations from a variety of sources such as the Canadian Legion and former president H.M. Tory rather than items chosen specifically for the college's programs. Soon the deliberate acquisition of materials became the top priority as "selection was Miss Gifford's thing," opened, it already housed 15,000 volumes, more than twice the number she had inherited, and it had shelf space for up to 40,000 more, ${ }^{61}$ by 1966 , the collection totalled 193,386 volumes with 35,834 only having been added the previous year. ${ }^{62}$ Like her trained colleagues, Gifford believed that an appropriate collection was defined by quality as well

\footnotetext{
${ }^{56}$ Muir, "Spacious New Library," 7, FN 373, Chapter 2.

${ }^{57}$ Ibid.

58 Ibid.

59 The new library was named for Carleton's second president who had died suddenly in 1955. Gifford not only visited other libraries for inspiration, but also consulted former Harvard University Librarian Keyes D. Metcalf who came on campus several times to offer his advice. Farr, Unpublished

${ }^{60} \mathrm{~S}$. Jackson, oral history.

${ }^{61}$ Muir, "Spacious library," FN 373, Chapter 2.

${ }^{62}$ Robert B. Downs, Resources of Canadian Academic and Research Libraries (Ottawa: Association of Universities and Colleges of Canada, 1967), 190-91.
} Tribute, 2. 
as quantity_ “whimsy was not in her book." 63 Over time, she developed collection policies and procedures in collaboration with faculty members who would become directly involved in book selection, both individually and through a succession of library committees she formed, in the manner of most Canadian academic libraries of the time. ${ }^{64}$ Gifford's "professional interest in librarianship" showed in her sustained exchanges with library colleagues at other institutions, both in Canada and internationally, a community amongst whom her work commanded much respect. ${ }^{65}$ In the late 1950 s and early 1960 s, she became one of eight consultants the Canadian Association of College and University Libraries (CACUL) chose to be in its standards committee chaired by Robert B. Downs; the committee developed performance measurements for Canadian academic libraries in key areas including shared faculty-librarian responsibility for book selection and numeric benchmarks for academic library holdings. CACUL considered such standards necessary in order to justify in front of governments and the public the need for higher resource allocations to academic libraries during a period of historic expansion in Canadian higher education. University administrators had largely ignored these needs in previous years as a result of inadequate funding. ${ }^{66}$

\footnotetext{
${ }^{63}$ Ben Jones, honorary degree citation for Hilda Gifford, 1, Library Historical Collection, Hilda Gifford File, University Communications, ACC-1996-17, PINFO 28 Convocation Fall 1982, Carleton University Library Archives, Ottawa, Ontario.

${ }^{64}$ Downs, Resources, 60. Faculty direct involvement in acquisitions was standard practice in Canadian academic libraries at this time. See also W.R. Taggart, "Book Selection Librarians in Canadian Universities," Canadian Library Journal 31, no. 5 (October 1974): 410-12.

${ }^{65}$ Susan Jackson, retired librarian, Carleton University, in oral history interview with Frances Montgomery, Carleton University librarian, and the author, April 24, 2012. See also Jones, honorary degree citation."

${ }^{66}$ Downs, Resources, 1-2. Professor Bruce MacFarlane from Carleton University sat on the steering committee for the Downs study.
} 
In addition to building design and collection development, Gifford also believed that a team of trained, full-time ${ }^{67}$ staff should manage an academic library and she began to hire professional librarians almost immediately. In 1951, the college library staff had increased from one to seven members: four "trained librarians" with degrees from either McGill or the University of Toronto, and three who appear to have been hired in clerical positions. ${ }^{68}$ This growth continued and by 1965 the MacOdrum Library reported a team of 15.5 professional librarians, 9 sub-professional librarians and 73 clerical workers. ${ }^{69}$ Although there was an "acute shortage" of librarians in Canada in the mid-1960s, Gifford managed to keep hiring professional staff, including future union organizers like Susan Jackson. ${ }^{70}$

She came back with buckets of librarians ... Every spring she would go off to the library schools and she would do interviews and she would come home with baby librarians, that was how I got hired. And so she'd come back from her trip and we would wait to hear who was coming. ${ }^{71}$

No yearly statistical evidence on the marital status of the librarians hired by

Gifford is available. She herself remained single, and in that respect continued to fit the early stereotype of the librarian as female and unmarried, but some her early library staff were married. "Mrs. Hilda Reid Cougle" was a graduate of the University of Toronto

\footnotetext{
${ }^{67}$ In the United States in the late 1800 s, the librarian was a part-time faculty member. Connie R. Dunlap, "Organizational Patterns of Academic Libraries, 1876-1976," College and Research Libraries (September 1976): 395-407. Robert Blackburn, in his history of the University of Toronto (U of T) Library, indicates that this practice existed at that library as well. For example, Henry van der Smissen was the U of T librarian for seventeen years (1874-1891) but this was only a "minor diversion" from his work as the head of the German department at University College. Blackburn, Evolution of the Heart, 51.

${ }^{68}$ Carleton University Library, "Carleton Library Staff," The Carleton (Thursday, December 6, 1951): 8, FN 373, Chapter 2. Doris Honeywell, Pat Spratt and Hilda Reid Cougle were hired as librarians. Non-professional staff included Hilda Freed (a British trained teacher), Majorie Milne (who had worked in the office of the federal minister of transport) and Wauneta Johnston (a high school graduate who had done courses at Carleton).

${ }^{69}$ Downs, Resources, 107. According to the report, the hiring of full-time staff could be considered as a reflection on the recognition of university administrators that academic libraries played a significant role in teaching and research.

${ }^{70}$ Downs, Resources; 1; S. Jackson, oral history.

${ }^{71}$ S. Jackson, oral history with F. Montgomery.
} 
Library school and began working at the Carleton library on June of $1951 .^{72}$ The women Gifford was hiring in the 1960s were of the past-war generation. This cohort, as will be discussed in Chapter 4 in more detail, saw the number of married women in the paid Canadian labour force rise significantly. As such, more of them may have been married when they began their careers as librarians. Valerie Swinton, for example, was married when Geoffrey Briggs hired her in the early 1970s. ${ }^{73}$ While increasingly marital status was less of a barrier to employment at that time than it had been at the turn of the century, it could still present obstacles to the pursuit of a professional career as a librarian for women. In particular, as will be discussed further in Chapter 4, married women with children were still not necessarily welcome in the labour force in the 1950s and 1960s.

Librarian Jean Weihs was working in the University of Toronto library when she became pregnant in 1959. She expected to return to work when her child went to school but "the chief librarian ... discouraged this intention by saying that he was certain I would want to stay home and look after my family." ${ }^{, 74}$ The chief librarian at that time was Robert H. Blackburn, author of Evolution of the Heart. Blackburn's attitude was very different from that of Eric Bow, the coordinator of technical services at the Ontario Provincial Service. Writing in 1974, Bow deplored what he believed to be a standard practice when hiring librarians: "If an older woman library school graduate returning to the work force and a young attractive woman graduate both apply for a position the younger woman is more likely to get the job, despite the fact that the older woman,

\footnotetext{
${ }^{72}$ "Library staff article," The Carleton (Thursday, December 6, 1951): 6, FN 373, Chapter 2.

${ }^{73} \mathrm{~V}$. Swinton, oral history.

${ }^{74}$ Weihs, "Women in Libraries," 11.
} 
having had her children, is more likely to stay." 75 Instead of discriminating against married women, Bow recommended that library administrators find more opportunities "to climb the career ladder and keep in touch with their field." ${ }^{, 76}$ Weihs did return to fulltime work and was the director of the Seneca College library technicians program from 1969 to $1986 .^{77}$

A significant number of these librarians were hired for traditional library work such as cataloguing, but Gifford was increasingly able to hire librarians who specialized in other areas, such as bibliography and book selection. ${ }^{78}$ Canadian librarians continued during this period to be concerned that there be a clear division of labour between professional and clerical library employees and the somewhat blurred reality at Carleton may have been representative of that at other libraries. ${ }^{79}$ The distinction between professional and "clerical" library work had been a concern to librarians in Canada and the United States since the early $20^{\text {th }}$ century and had informed Charles Williamson's recommendations for education reform in the 1920s. Typically, librarians would be promoted to managerial positions such as departmental heads and had exclusive access to specific functions such as reference work while non-professional staff were assigned jobs considered to be clerical or mechanical, routinized tasks. ${ }^{80}$ However, Carleton librarian Valerie Swinton worked with library assistants in both the acquisitions and cataloguing sections at the university "who were doing work at a high enough level that ... they felt

\footnotetext{
${ }^{75}$ Eric Bow, "Interrupted Careers: The Married Woman as Librarian," Ontario Library Review 56, no. 2 (June 1972): 76.

${ }^{76}$ Ibid., 77.

${ }^{77}$ FN 169 in Chapter 4 of this thesis.

${ }^{78}$ S. Jackson, oral history.

${ }^{79}$ Charles Deane Kent, "What is a Professional?," Ontario Library Review (May 1957): 89. The OLA established a professional committee to set benchmarks for as standard of professionalism for librarians.

${ }^{80} \mathrm{~V}$. Swinton, oral history. In his 1921 report, Williamson is explicit of the need for university training for librarians and a more general education for the library employees who needed to learn the "mechanics and routine operations of the library." Charles C. Williamson, "Training for Library Work," 11.
} 
that they were doing librarians' work." ${ }^{81}$ This belief might have stemmed not only from the nature of the assistants' own work, but their understanding that librarians like Swinton were also filing cards in the card catalogue or, like Frances Montgomery, did not always receive the necessary on-the-job training or direction to perform certain functions. ${ }^{82}$ Similarly, at the University of Guelph, Library Director Margaret Beckman was hiring "library assistants" for the various subject divisions in the library. These support staff had academic degrees in the disciplines for which they offered "quick reference, information, and instructional services" 83 — work that might be done by librarians at another institution. Occupational boundaries became more formalized in the mid-1960s when support staff positions across the university were classified under the Hay job evaluation system into three non-professional streams: administrative, clerical and technical. ${ }^{84}$

In keeping with the historically gendered nature of librarianship, most of the new librarian hires were women rather than men-as Susan Jackson has been known observe, the shortage of men meant that there were "not many treasures" working at the Carleton Library. ${ }^{85}$ By 1975 , when CUASA certified, two of the thirty librarians in the bargaining unit were men. ${ }^{86}$ Although women were chronically underpaid, relative to their male peers, Gifford's salary over the course of her term as chief librarian seems to have been

\footnotetext{
${ }^{81} \mathrm{~V}$. Swinton, oral history.

${ }^{82}$ V. Swinton, oral history; Frances Montgomery, librarian, Carleton University, in oral history interview with the author, June 10 2011. I worked full-time as a junior library clerk at Coquitlam Public Library in Coquitlam, British Columbia from 1976-1977 and did this kind of clerical work.

${ }^{83}$ Margaret Beckman, "Implications for Academic Libraries," In Collective Bargaining in Libraries (Papers presented at the Allerton Park Institute 1974), ed. by F.A. Schlipf, 126, accessed November 30, 2013, https://www.ideals.illinois.edu/handle/2142/499.

${ }^{84} \mathrm{M}$. McEown, oral history. See Chapter 4 of this thesis for discussion of the introduction of the Hay system at Carleton in the mid-1960s.

${ }^{85}$ F. Montgomery, oral history.

${ }^{86}$ Geoffrey Briggs, "Ranking of librarians," Office of the vice-President Academic fonds, OVPAC78-8, Carleton University Corporate Archives, Ottawa, Ontario.
} 
remained competitive with that of senior librarians in Canada. In 1947, the Canadian average salary for academic librarians was $\$ 1,512$ (including those at both large and small libraries) ${ }^{87}$ and Gifford was hired a year later at a starting salary of $\$ 2,800 .^{88} \mathrm{In}$ 1969 , she was earning $\$ 16,500$ per year, and in 1966 , the mean salary for chief librarians in Canada was $\$ 14,767$. For other ranks in 1966, typically salary scales at Canadian university libraries started at approximately $\$ 6,000$ for general and senior professional librarians. At Carleton, the lower end of the scale of $\$ 6,400$ was higher, and the median salary for a professional librarian was $\$ 6,800$, excluding that of the chief librarian. ${ }^{89}$ When Susan Jackson was hired as a cataloguer in 1965 , her annual salary was $\$ 6,500$; within four years she was promoted to head of cataloguing and paid $\$ 10,000$ per year: "I was just so rich!"90

Wage differentials between Canadian male and female librarians are also hard to establish for this period. Perhaps, however, as was the gap between male and female professors reported in Chapter 2, women may have been making significantly less than men - if not at the beginning of their careers then over the course of their working lives as librarians. For example, Jean Weihs graduated from the University of Toronto (U of T) library school in 1953 and was hired as a bibliographer to work in the U of T library. ${ }^{91}$ She reported that her salary only differed from that of a fellow male graduate by $\$ 100$ : she had a starting salary of $\$ 2,400$ and his was $\$ 2,500$. Looking back, she realized that while the difference in earnings seemed small initially, the gap grew for over time. "I do know that the men in my graduating class rose very quickly in library hierarchies to

\footnotetext{
${ }^{87}$ Survey of Libraries 1946-48, 19.

${ }^{88} \mathrm{CU}$, Minutes of the $38^{\text {th }}$ Meeting of the BOG, 2, FN 1, Chapter 1.

${ }^{89}$ Ibid., 119.

${ }^{90} \mathrm{~S}$, Jackson, oral history.

${ }^{91}$ Weihs, "Women in Libraries," 10.
} 
become heads of departments and of libraries. The chief librarians of most libraries were male. ${ }^{92}$ As the Downs report revealed, librarians in these senior positions made significantly more than their subordinates. The following table shows that not all universities submitted information for ranks. As Table 3.1 demonstrates, however, for those that did there was a significant wage differential.

Table 3.1 Professional Salary Scales (1967-1968) for Selected Ontario Universities ${ }^{93}$

\begin{tabular}{|c|c|c|c|c|}
\hline Institution & $\begin{array}{l}\text { General and } \\
\text { Senior } \\
\text { Librarians } \\
\end{array}$ & $\begin{array}{l}\text { Departmental } \\
\text { and Division } \\
\text { Heads }\end{array}$ & $\begin{array}{l}\text { Assistant and } \\
\text { Associate } \\
\text { Librarians } \\
\end{array}$ & $\begin{array}{l}\text { Chief } \\
\text { Librarians }\end{array}$ \\
\hline Brock & $\$ 6,660-\$ 8,350$ & $\$ 7,900-8,100$ & $\mathrm{n} / \mathrm{a}$ & $\mathrm{n} / \mathrm{a}$ \\
\hline Carleton & $\$ 6,400$ & $\$ 8,000$ & $\mathrm{n} / \mathrm{a}$ & $\mathrm{n} / \mathrm{a}$ \\
\hline Guelph & $\$ 6.600$ & $\$ 8,500$ & $\$ 11,000$ & $\$ 16,000$ \\
\hline Ottawa & $\$ 6,500-9,225$ & $\begin{array}{l}\$ 9,500- \\
12,350\end{array}$ & $\mathrm{n} / \mathrm{a}$ & $\$ 13,900$ \\
\hline Queen's & $\$ 6,300$ & $\$ 9,00$ & $\$ 13,000$ & $\$ 18,765$ \\
\hline Toronto & $\$ 6,800$ & $\$ 8,300$ & $\mathrm{n} / \mathrm{a}$ & $\mathrm{n} / \mathrm{a}$ \\
\hline Trent & $\$ 6,600-9,000$ & $\begin{array}{l}\$ 8,000- \\
11,000\end{array}$ & $\mathrm{n} / \mathrm{a}$ & $\mathrm{n} / \mathrm{a}$ \\
\hline
\end{tabular}

Carleton librarians might have compared their salary scales to those of these institutions. Original data published in the Downs report.

Unlike their faculty colleagues, Carleton librarians working at the university during this period do not seem to have complained openly about lower-than-average salaries but there is no evidence to suggest why this might be the case even though Gifford was undoubtedly aware of the broader national discussion about occupational status. The 1967 Downs report on resources for academic and research libraries devoted some space to discussing this issue and warned university administrators that they would

\footnotetext{
${ }^{92}$ Ibid.

${ }^{93}$ Downs, Report, 118.
} 
have difficulty recruiting "enterprising and ambitious" librarians if "status is

unsatisfactory." ${ }^{94}$ More pointedly,

the qualified librarian can be placed in any type of library that interests him ... the institutions that are most successful in attracting and holding able staff members are those where librarians are recognized as an integral part of the academic ranks, a vital group in the educational process, with high qualifications for appointments, and all the rights and privileges of other academic employees. ${ }^{95}$

Whether the authors assumed that most libraries were targeting male recruits or not, libraries participating in this study submitted descriptions of the status of their professional librarians and the statement for Carleton that appeared in the Downs report reveals that they were considered to be non-academic employees: "Librarians have faculty status socially and in academic processions, but are regarded as a professional group, eligible for study leaves, faculty club and retirement benefits. The chief librarian serves on faculty committees." 96

Gifford actively promoted a sense of collegiality and professionalism within her team. Some of her efforts were informal and could include all library staff, such as the ritual of the morning break where new librarians like Susan Jackson were called upon to play hostess - a role that might not have been appealing to the "able librarians" singled out in the Downs report. "When I started at the library in 1965 during the HGG era (Miss Gifford's memo signature) the junior librarians made tea for everyone and she bought the cookies. ${ }^{97}$ Jackson also remembers that these efforts to "socialize" at least the female

${ }_{94}^{94}$ Downs, Resources, 110.

95 Ibid.

${ }^{96}$ Ibid., 113.

${ }^{97}$ This coffee ritual was important in the working days of library staff and all of the library staff that I interviewed remembered it fondly. At some point after Hilda Gifford retired as chief librarian, Monica Cruikshank was hired to be the "tea lady." According to Susan Jackson, Monica would serve coffee and cookies to everyone in the staff lounge ... we paid, and people would sit in the lounge in their groups and it was not always just departmental groups, there was quite a bit more mixing than there is now." Susan 
staff also included events that Gifford would hold outside of the library. Librarians do not seem to have been included in Gifford's famous Scottish country dancing parties, as were her faculty friends and colleagues, but were invited to her home on other occasions although their role was seemingly similar to that at the coffee hours; as Jackson wryly notes, it was a "different time." "98 Jackson remembers that Gifford "often sponsored get togethers at her house ... she used to have her young librarians, her young ladies, ... come and serve at her tea parties and her evening parties. We got to pass around the canapés. ${ }^{99}$ Although she promoted social interactions for and amongst her librarians, Gifford clearly did not define collegiality in the scholarly sense of a working relationship amongst peers; these examples reveal that she had firm ideas about social hierarchy that reinforced the existing bureaucratic division of Carleton librarians into those with senior status and those considered junior members of the professional team.

Gifford also encouraged her colleagues to engage in more formal work-related activities such as participation in professional organizations. ${ }^{100}$ More explicitly, she suggested that the librarians engage with the campus community and "have a presence so that we would be seen as part of the picture." ${ }^{, 101}$ One of the more popular options was to join the faculty club, which librarians did because "it was one of the few status things that was available to us." ${ }^{, 102}$ Gifford also advocated for institutional acknowledgement of the contribution that librarians made to the university. In particular, she insisted that the

Jackson, retired librarian, Carleton University, e-mail message to author, November 15, 2012. See Chapter 4 of this thesis for library support staff memories of these coffee breaks.

${ }^{98} \mathrm{~S}$. Jackson, oral history.

${ }^{99}$ Ibid.

${ }^{100}$ Throughout her tenure at Carleton, Gifford appears to have consistently been a member of various library associations at the local, provincial, national and international levels and involved in various activities related to professional standards. Jones, honorary degree citation.

${ }^{101}$ Ibid.

${ }^{102}$ S. Jackson, oral history with F. Montgomery. 
librarians be invited to the general faculty board meeting hosted by President A.D. Dunton each fall and that their names be listed in the university calendar, "right after" those of professors. ${ }^{103}$ These forms of recognition were significant enough to the librarians that when they were neglected, at least some of Susan Jackson's colleagues were openly unhappy. "We used to get an invitation ... And then one year we didn't get an invitation and it was a big hoo-hah. Where are our invitations? And ... one year they dropped the librarians out of the calendar. And so then that caused a big hoo-hah as well." 104

Hilda Gifford was not a supporter of unions, in fact she "had no interest in unionizing, she thought it was a terribly bad idea." ${ }^{\prime 105}$ Yet, as the chief librarian, she helped to nurture a culture at Carleton that facilitated unionization to some degree. This environment not only contributed to an on-going consciousness of librarianship as both professional and academic work but also reinforced to some degree the gendered nature of the occupation. She had designed and developed a library based on occupational standards that was staffed and managed by trained librarians and promoted the recognition of their contribution to the educational work of the university. Moreover, through her own activities, she reinforced the role of occupational associations as a mechanism through which librarians could regulate their working conditions. However, Gifford also hired a generation of librarians who she socialized to be "young ladies" and whose work was still not recognized as either academic or professional in nature. She resigned as the head librarian in 1968 to take on the role of collections librarian at Carleton leaving this legacy and, as such, when the Carleton librarians began to organize

\footnotetext{
${ }^{103}$ Ibid.

${ }^{104}$ Ibid.

${ }^{105}$ Ibid.
} 
in the mid-1970s, the idea of their status as academic, professional staff might have seemed relatively new but in fact was not.

\section{Conversations About the Status of Librarianship}

When Susan Jackson first arrived at Carleton to study history in the early 1960s, there was "lots going on" including presentations by invited speakers, hootenannies and the commotion generated by the Cuban missile crisis of 1962 that led to phones in residence "ringing off the walls" as students called their parents "to say goodbye."106 By the end of the decade, the university community had gotten "a little more excitable." Anti-war protests were not uncommon and library staff had to contend with protecting the shelf list because "one of the Marxist groups, or somebody was fulminating against the university" and had threatened to destroy these unique library records. ${ }^{107}$ Certainly challenges to the status quo were now the order of the day as Canadians across the country were caught up in Trudeaumania, public sector labour action as well as the debate surrounding the status of women and both Carleton faculty and support staff members were questioning their workplace status. In the late 1960s, as Carleton professors started pushing for binding negotiations with senior administrators and as support staff in the library tried and failed to unionize, Carleton's professional librarians were more focused on day-to-day responsibilities and special projects, such as the introduction of technological change to library processes, rather than in gaining new rights and privileges. Nonetheless, they were aware to some extent of the conversations amongst other librarians outside Carleton, provincially and nationally, concerning

${ }^{106}$ Ibid.

${ }^{107} \mathrm{Ibid}$. The shelf list is a record (kept on cards) of the books and other materials in a library in the order in which they stand on the shelves. As Jackson explains, it is the "unique item identification."

S. Jackson, oral history. 
occupational prestige, especially on the questions of the status of women in librarianship, professionalization versus unionization and academic status.

In the early 1960s acquisitions librarians at North American university libraries would have had some interesting choices to consider for collection development as faculty and students began to ask for new best-selling books such as Betty Friedan's The Feminine Mystique and English translations of Simone de Beauvoir's The Second Sex as traditional "sex roles"108 became a topic of public discussion. Work, both paid and unpaid, was of great interest given that since the end of World War II Canadian women had been entering the labour market in record numbers to take on a variety of jobs from the most menial to leadership roles in organizations such as the Canadian Union of Public Employees (CUPE). ${ }^{109}$ More particularly, many Canadians were talking about the "double ghetto": the traditional division of labour that gave women primary responsibility for unpaid housework and child care in the home and segregated them into “specific industries and occupations characterized by low pay, low skill requirements, low productivity and low prospects for advancement" in the paid labour force. ${ }^{110}$

Librarians contributed to this public conversation, which in some respects was a continuation of the discussions that had preoccupied them since the early $20^{\text {th }}$ centurylow salaries, poor advancement opportunities, lack of recognition for skill and expertise, women in the workplace. One of the most outspoken advocates for change was Sherrill Cheda, a librarian at Ontario's Seneca College in the 1970s, whose views on the inferior status of women in her profession received national coverage. At the annual Canadian

\footnotetext{
${ }^{108}$ Monica Boyd, Canadian Attitudes Toward Women: Thirty Years of Change, Women's Bureau, Labour Canada, (Ottawa: Minister of Labour, Government of Canada, 1974), 3.

${ }^{109}$ Armstrong and Armstrong, The Double Ghetto, 17 and 53. Susan Crean, Grace Hartman. A Woman for Her Time (Vancouver: New Star Books, 1995).

${ }^{110}$ Ibid., 20.
} 
Library Association (CLA) conference held in Sackville, New Brunswick in June 1973, a "damn angry" Cheda made an impassioned plea for change in a presentation entitled "That Special Little Mechanism." ${ }^{\text {111 }}$ Her argument was simple: as a woman and a librarian without the "special little [biological] mechanism" she was battling a "heritage of sex discrimination" that assigned men to "executive duties" and women to the lower paying "housekeeping duties." "112 Instead of accepting the patriarchal "masculine mystique" that led to inequitable gender roles in librarianship in particular and society in general, she suggested that librarians had a duty to alleviate workplace unfairness in a number of ways, such as creating more part-time jobs for working mothers and ensuring that women got promoted into senior leadership positions. Anyone who missed hearing her speak could read her presentation in the October 1974 issue of the Canadian Library Journal. ${ }^{113}$

Also presenting at the 1973 CLA conference was Jack Hughesman, the director of education for the prairie region of CUPE. Hughesman's goal was to debunk some of the popular myths about unions, and encourage librarians to unionize. He urged them to break the stereotype of "small grey-haired elderly people with wire-rimmed glasses who shuffle around a building with books in it saying sh-h-h-h-h" and assert their professionalism by joining a union. ${ }^{114}$ As he pointed out, CUPE represented

${ }^{111}$ Sherrill Cheda, "The Special Little Mechanism," 423. Susan Jackson and Frances Montgomery did not remember attending this conference or reading the article, but a copy of this issue of the Canadian Library Journal was still in Susan Jackson's papers when she cleaned out her office in 2012 in preparation for her retirement from Carleton after more than 40 years. Cheda's opening remarks refer to Mount Allison College and it seems likely that the conference was held at the college.

${ }^{112}$ Ibid.

${ }^{113}$ Ibid., 431. Cheda and several colleagues (including long-time Ottawa Public Library chief librarian Barbara Clubb) went on to publish the Emergency Librarian, a feminist journal dedicated to "radical change." Susan Klement, "Feminism and Professionalism in Librarianship. An Interview with Sherrill Cheda," Canadian Library Journal 31 (November-December 1974): 522

${ }^{114}$ Ibid. 
approximately $80 \%$ of the unionized library staff in Canada (most in public libraries) and although the overall percentage of library workers in unions was significantly lower than the national average at a time, librarians' with collective agreements could make as much as $25 \%$ more than their non-unionized peers. ${ }^{115}$ While CUPE might have been having some success unionizing public libraries, these bargaining units frequently included all library workers ${ }^{116}$ and it is likely that Hughesman would have met with some resistance from professional librarians, given that in Canada and the United States they had chosen professionalization over unionization since the early $20^{\text {th }}$ century. ${ }^{117}$

Forty years later, Canadian librarians were also still attempting to regulate and improve their occupational status within a professional context but not with great success. As discussed in Chapter 1, the formation and development of the Institute of Professional Librarians of Ontario (IPLO) highlights the challenges that librarians faced in establishing their professional status. Most relevant in this case was the inability of the IPLO to secure the regulatory powers from the Ontario government that would have allowed the institute to license librarians in the province and negotiate with the province in a manner similar to that of other regulated professions such as medicine and dentistry. As such, there was no strong, central organization either provincially or nationally to represent the occupational interests of librarians on matters related to terms and conditions of work.

\footnotetext{
115 Jack Hughesman, "Union Representative Looks at Librarians," Canadian Library Association Conference 1973 Proceedings (CLA: 1973): 101-06; In his study of American librarians' attitudes to unions, Theodore Guyton also noted that between 1917 and 1970, only forty-five public library unions had been formed in the United States. Theodore Guyton, Unionization: The Viewpoint of Librarians, (Chicago: American Library Association, 1975), 12-15.

${ }^{116}$ Mudge, "Collective Bargaining of Librarians," 94.

${ }^{117}$ See for example, Shanley, “The Library Employees’ Union.”
} 
Librarians' historical preference may have been for professionalization, but unionist Hughesman's presence at the CLA conference of 1973 was not completely unexpected. Between 1957 and 1970, union membership in Canada had grown by $57 \% .{ }^{118}$ The initially the greatest growth was from 1940 to 1956 amongst semi-skilled workers from and then latterly amongst white-collar workers in the public sector, many of whom who joined either the newly formed CUPE or Public Service Alliance of Canada. ${ }^{119}$ Growth in Ontario would be second only to that in British Columbia ${ }^{120}$ and CUPE would be very successful in its certification drives in Canadian libraries; and as previously mentioned, by 1975 the union would represent $91 \%$ of staff members working in public libraries and $48 \%$ of university libraries in the country. ${ }^{121}$ CUPE organizers had less success in organizing faculty members despite the growing interest of academic staff in unionization during the 1970s and so in many ways, the unionization of Carleton librarians can be understood in the context of a competition between CUPE and the Canadian Association of University Teachers (CAUT).

Instead of joining trade unions, professors were taking the lead from their own occupational organizations, including the Canadian Association of University Teachers (CAUT), which began to promote the certification of faculty unions as well as academic status for librarians during a period of retrenchment in both federal and provincial

${ }^{118}$ Eaton, Union Growth in Canada, 11. Eaton attributes some of this growth to the increase in the number of government employee associations.

${ }^{119}$ Ibid.

${ }^{120}$ Ibid., 43.

${ }^{121}$ CUPE, Background. For example, according to Hilary Richardson, the Non-Professional Association at the Douglas Library at Queen's University officially became CUPE Local 1302 on July 1, 1970. Hilary Richardson, “The Douglas Library in 1967," originally published in 1998, accessed May 3 , 2012http://qspace.library.queensu.ca/bitstream/1974/1614/1/DOUGLAS_1967.pdf. 
funding for higher education. ${ }^{122}$ CAUT members seem to have ignored academic librarians until 1973, the same year that Carleton librarians began to take collective action. Librarians had begun to gain membership in faculty associations in the mid-1960s, which de facto guaranteed them membership in the national faculty association, but no centralized attempts were made to acknowledge their presence or address issues specific to librarianship until the mid-1970s when the CAUT governing board began to become interested in collective bargaining for academic staff. A special report published in the CAUT newsletter in March 1976 explained this neglect it in terms of the tired misconceptions regarding librarians: faculty perceived librarians as "clerks who pass books over a counter and otherwise jealously guard these books"; that is, no differentiation between professional librarians and no-professional staff. ${ }^{123}$ However, in the early 1970s CAUT representatives began to support the idea that there was a sufficient "community of interest" between librarians and faculty, based in part on the shared need for intellectual freedom, to justify including librarians in academic associations.

Between 1973 and 1975, CAUT members changed the organizational constitution to allow librarians to be members and formed a partnership with CACUL. This collaboration resulted in the Guidelines on Academic Status for University Librarians that was published in March 1976 and endorsed the membership of librarians in faculty associations and set out a series of recommendations on key terms and conditions of

\footnotetext{
${ }^{122}$ Calvin D. Evans, "Librarians and CAUT: Historical Overview and Future Directions," CAUT Bulletin 24, no. 5 (March 1976): 12.

123 Ibid., 13.
} 
employment for librarians including appointments, promotions and salaries. ${ }^{124}$ At the same time, just as they advocated for collective bargaining as a way for faculty to "achieve old ends with new means"125 members of the CAUT executive also suggested that unionization would be an effective strategy for librarians to achieve work-related goals such as increased salary levels and greater input into university decision-making. ${ }^{126}$ This support came during the period when CUPE organizers were actively trying to certify academic staff and librarians and some librarians were also considering forming separate associations because they did not want to be identified as "pseudo faculty." ${ }^{127}$ It is not clear if Carleton librarians were aware of all the CAUT initiatives but certainly some, such as Valerie Swinton who became a key Carleton organizer, were participating in discussions about academic status held by other organizations such as the CLA. ${ }^{128}$

To summarize, between 1968 and 1973 Canadian librarians were involved in a number of key discussions that related to their occupational status. Women were questioning traditional gender roles that segregated them into low-status jobs and landed them at the bottom of occupational hierarchies. In general, librarians were struggling to regulate their occupation and gain greater professional status at a time when more and more public sector workers in Canada—professional and non-professional—were opting for unionization as an effective strategy for improving terms and conditions of work. Academic librarians were being given the option to align themselves with faculty members and thus not only gain bargaining power but also the means to differentiate

124 "Guidelines on Academic Status for University Librarians," CAUT Bulletin 24, no. 5 (March 1976): 19-22.

125 Savage, "CAUT and Collective Bargaining," 2. 14.

${ }^{126}$ Kenneth B. More, "Collective Bargaining for Librarians," CAUT Bulletin 24, no. 5 (March 1976):

127 Ibid.

${ }^{128}$ V. Swinton, oral history. 
themselves from all other library staff who could not possibly claim a "community of interest" with professors. As a group, Carleton librarians did not participate actively in these debates but individually some were ready to at least meet with others to discuss the issue of their occupational status in late 1973 and early 1974.

\section{The Association of Professional Librarians of Carleton University joins CUASA}

The professional librarians at Carleton University began to join these broader conversations more actively in the early 1970s and, as was true for previous generations of North American librarians, pay was a catalyst for action. Librarian Valerie Swinton succinctly expressed their concerns in a letter to Professor R.J. Crowther, the director of the CAUT office in Halifax, dated May 9, 1974: for several years the professional librarians had been dissatisfied with their "salary increases" and had come to realize that there were no formal policies and procedures to define their work and thus their occupational status. ${ }^{129}$ As a result, the "position of librarians is undefined in a number of areas ... librarians are considered neither academic nor non-academic staff. ${ }^{, 130}$ In response to this general discontent, the librarians had formed the Professional Staff Committee in January 1974 as an institutional forum for addressing these issues. This committee turned out to represent the first phase of labour activism for the Carleton librarians and over the next eighteen months they reorganized their efforts three times. In November 1974, they "regularized their relationship with each other" ${ }^{\text {"131 }}$ by forming the Association of Professional Librarians of Carleton University (APLCU); in February 1975 many joined the Carleton University Academic Staff Association; and in June 1975

\footnotetext{
${ }^{129}$ Valerie MacDougall to Professor R.H. Crowther, May 9, 1974, 1, in the author's possession. ${ }^{130}$ Ibid.

${ }^{131}$ Frances Montgomery, handwritten note, n. d., in the author's possession.
} 
they became members of a legal bargaining unit when the Ontario Labour Relations Board (OLRB) certified CUASA. Throughout this transition, the librarians were driven by a moral agenda. As Swinton explains, they wanted to participate in decision-making related to their employment.

The motivation to it was more to have greater say in making decisions for the library ... some librarians felt that ... "Wouldn't it be nice if we could all sit together and talk this out and have our ideas heard as well?" Because we were a small group of professional librarians and just felt we weren't ever consulted about things. ${ }^{132}$

Ultimately, the journey to unionization would be a quest for equity through the recognition of their status as professional, academic staff.

Between January and October 1974, the professional staff committee members pursued two key goals: to develop work standards and to identify a more formal group with which they might align in order to "effectively represent our interests."133 They made some early, though limited, progress in their efforts to identify appropriate terms and conditions of work. The formation of the committee coincided with the efforts of the IPLO to develop a framework for professional employment and work standards that could be modified and adopted for all library sectors (i.e., public, government, school, special and academic libraries). The IPLO had distributed a draft of these guidelines to librarians across the province in 1974, and the professional staff committee used the standards to assess the policies and procedures at Carleton. ${ }^{134}$ Committee members compared current practices at Carleton to the IPLO guidelines and confirmed that in key areas of employment such as appointments, employment contracts, security as well as promotions, there were no stated and accepted standards in practice at the university. For

\footnotetext{
${ }^{132}$ V. Swinton, oral history.

133 Ibid.

${ }^{134}$ Martin Foss, memo to all professional staff, May 2, 1974, in the author's possession.
} 
example, when Swinton was promoted to the position of head of the serials department she did not have to compete formally with other candidates.

In those days, the way you got the job was the chief librarian chose you. There was no competition. He took me for lunch at the Faculty Club and said, "I'd like to offer you this position, I think you can do it." And I was flabbergasted because ... how old was I when I came to Carleton? I think I was 27 or 28 by that time. And I'd only had a couple of years' experience and I didn't know anything about serials other than what I'd learned in library school. ${ }^{135}$

Likewise, the conditions of work did not include job descriptions or evaluations nor was there any formal grievance procedure. Feedback gathered on each clause of the IPLO document via a survey indicated that there was "broad support" from the majority of professional librarians for using the guidelines as a basis for work standards at Carleton and the committee seems to have been hopeful that the IPLO framework might be discussed with Geoffrey Briggs. However, although Briggs had invited librarians to make a "formal reaction" to a proposal from President Michael Oliver regarding discretionary salary (i.e., merit) increases earlier in the spring, the committee's attempts in July to pursue the issue of work standards with him seem to have been unproductive. ${ }^{136}$

The committee was even less successful in identifying a larger group that would be willing to form an alliance or act on their behalf. They considered a number of options including membership in the Professional Institute of the Public Service of Canada (PIPSC) or the formation of their own bargaining unit but had started by contacting CUASA in April 1974. CUASA seemed a natural choice given their historical understanding of librarianship as educational work and the fact that the association already represented the university's academic staff (including certified professionals such as engineers) but faculty members had either missed or rescheduled the three meetings

\footnotetext{
${ }^{135}$ Ibid.

${ }^{136}$ Ibid.
} 
they had arranged with the librarians in early $1974 .{ }^{137}$ Other academic librarians in Ontario were also concerned about working conditions and more receptive to collaboration so in September Swinton and Carleton colleague Elspeth Ross travelled to York University in Toronto in September 1974 to attend a meeting of university and college librarians who had gathered to informally discuss the issue of librarian membership in faculty associations as well as collective bargaining. ${ }^{138}$

In a report to their Carleton colleagues, Swinton and Ross indicated that the meeting was "essentially a forum for exchange of information" between professional staff from different institutions but in fact there was some urgency to the discussions. Both CAUT and the Ontario Confederation of University Faculty Associations (OCUFA) were actively debating the question of collective bargaining for faculty and alternatives to trade unionism. ${ }^{139}$ OCUFA in particular had proposed a two-tier system in which the university presidents would negotiate salaries and working conditions with both the province and their own institutions. Given that only seven of the fifteen Ontario universities were full members of faculty associations, if the OCUFA two-tier model was introduced some librarians would be included in bargaining and others not. ${ }^{140}$ OCUFA representatives had invited comments from librarians on the proposed bargaining model and those present at the "York Meeting" unanimously endorsed the proposal. They also agreed to review a brief on academic status that some members of the group were preparing for presentation to OCUFA executive members in October, despite the fact that

${ }^{137}$ Ibid.

${ }^{138}$ The status of the professional staff committee is hard to determine. It seems from the documentary evidence that it had official sanction and support from the chief librarian and its members were involved in issues related to collective bargaining. The group appears not to have met regularly or kept official minutes. A number of librarians seem to have been active including Valerie Swinton, Elspeth Ross and Martin Foss.

${ }^{139}$ Professional Staff Committee, Carleton University Library, Report of York University Meeting of University and College Librarians in Ontario, September 1974, in the author's possession.

${ }^{140}$ Cal Evans, Report on York Meeting (n.d.), 1, in the author's possession. 
initial reports from Jill Vickers, the current CUASA president and Philip Hull, a University of Guelph librarian, that individual OCUFA representatives had responded coolly to the idea of academic status for librarians - perhaps because "academics do not understand the nature of librarianship" and feared "spreading benefits like sabbaticals too thinly." 141

The "York Meeting" signalled the next phase in the collective action of Carleton librarians. If the OCUFA two-tier negotiating proposal was accepted, then membership in CUASA could lead to collective bargaining and Carleton librarians would be amongst those in the province without representation. On October 1, 1974, Swinton and colleague Martin Foss sent a memo to Vickers regarding membership of librarians in CUASA and this time they received a quick reply. Vickers wrote back on October 10 with the news that the issue of librarian membership was raised at a CUASA council meeting in late September and as usual, "Council voted to establish a Committee to examine the question further!" ${ }^{142}$ Nonetheless, she could report that CUASA was "seriously" considering the possibility of applying for certification to the Ontario Labour Relations Board (OLRB) and, as such, the association would be in a position to potentially offer professional librarians some substantive membership benefits—-something that Vickers frankly believed would not necessarily have been possible otherwise because the association lacked "the power to negotiate salary increases and fringe benefits for our own members" (i.e., the teaching faculty) let alone those from another occupational group. ${ }^{143}$

\footnotetext{
${ }^{141}$ Professional Staff Committee, Report of York Meeting. It is unclear whether Jill Vickers was at the September meeting at York University. Swinton and Ross's notes imply that she was but a report from Cal Evans on the meeting does not include her as one of the attendees although Phil Hull was there.

${ }_{142}$ Jill Vickers to Martin Foss and Valerie MacDougall, Thursday, October 10, 1974, 1, in the author's possession.

${ }^{143}$ Ibid.
} 
With this information in mind, and support from OCUFA council for unofficial discussions between librarians and faculty association representatives, Vickers was agreeable to meeting the following week. "An informal luncheon meeting" was held and turned out to be quite productive. Vickers cautioned the librarians that their academic colleagues still did not understand librarianship or their need for benefits such as study leave but, despite this lack of widespread support, she would be recommending to the CUASA council members that they form two committees: one to study membership for librarians, and librarians would be appointed to this group; and a second to consider collective bargaining. The latter committee would be organizing a series of education sessions for professors on unionization organized in the near future and she would suggest that librarians would be invited to attend these presentations. Most importantly, she was anticipating that a vote on collective bargaining would be held for CUASA members in May $1975 .^{144}$

Vickers was true to her word. She arranged to have the librarians put on the mailing list for the CUASA newsletter, (CUASA News), and in the very next issue readers were alerted to the fact that Professors Antonio Urrello and Andrew Brook had made the following motion at a recent council meeting: "That the Steering Committee from [sic] an ad hoc committee to explore librarians' membership and to consider other categories of membership." 145 Although they had now started a tentative — and seemingly positiverelationship with CUASA, the librarians decided to formalize their relationships with each other as well as other organizations by creating the Association of Professional

\footnotetext{
${ }^{144}$ Note to librarians regarding meeting with CUASA President Jill Vickers, Wednesday, October 23, 1974, in the author's possession.

145 “Council Summary," CUASA News 5, 1: 2 (, October 1974), FN 1, Chapter 2.
} 
Librarians of Carleton University (APLCU).${ }^{146}$ Membership was voluntary and those who had decided to join held their first meeting on Thursday, November 14 at which much was accomplished: a constitution was adopted and three officers were elected (President Valerie Swinton, Vice-President Elspeth Ross, Secretary Treasurer Peggy Atherton) in addition to three committee chairmen (Susan Jackson, Salary; Erika Fuerst, Conditions of Employment and Work; Frances Montgomery, Job Description and Classification). According to Jackson, the APLCU was "really the precursor to moving towards unionization" ${ }^{\prime 147}$ and over the next three months the new association met virtually every week to address on-going issues and two of the association members (Swinton and Neal Brearley) were assigned to the CUASA subcommittee tasked with exploring "enlarged CUASA membership." ${ }^{148}$ Members also continued to collaborate with other academic librarians on work-related issues, including colleagues at the University of Ottawa as well as those involved in the earlier discussions at York University who seem to have formalized their own collaboration with the establishment of the Association of Academic Librarians of Ontario (AALO). In addition, Valerie Swinton participated in efforts by CAUT and CACUL to develop a national statement on academic status for librarians. ${ }^{149}$

The APLCU's agenda during this period was heavily influenced by the CUASA council decision to move forward with collective bargaining. Faculty members had been on "high alert" since the Carleton general faculty board meeting in September 1974.

\footnotetext{
${ }^{146}$ Professional Staff Committee, Notice of Meeting, n.d., in the author's possession.

${ }^{147}$ S. Jackson, oral history.

${ }^{148}$ Association of Professional Librarians of Carleton University (hereafter APLCU), Minutes of the First Council Meeting on Thursday, November 21, 1974, in the author's possession. Note: All these minutes are in the author's possession. As such, this information will only be cited once, in this footnote. Subsequent footnotes will be referenced back to FN 148, Chapter 3.

${ }^{149}$ APLCU, Minutes of the Meeting on May 29, 1975, 1, FN 148, Chapter 3. CACUL was a division of the Canadian Library Association.
} 
Generally it was understood that the Canadian economy was currently in a downturn and in addition "there was a great deal of buzz because it was very clear that the ... provincial funding was not going to be good." ${ }^{150}$ At the September meeting, President Oliver famously announced that "there really isn't much hope for getting any more money for ... salaries unless you unionize." ${ }^{151}$ Moreover, many present understood him to suggest that the only way to solve the university's current financial crisis might be to lay off faculty members, a message that Geoffrey Briggs repeated at a subsequent meeting with library staff in which he indicated, "that the funds were really bad, it was highly unlikely that anybody was going to get any more money, that people might be let go, and the only way to save yourself was to bring political pressure to bear." 152 At a meeting on November 29 , fifty-three CUASA members (or less than $10 \%$ of full-time faculty) voted to "endorse collective bargaining in principle" and this support was sufficient for the CUASA council to launch an official certification drive. ${ }^{153}$ A special issue of CUASA News published in early January provided background information so that faculty members could prepare themselves to debate both the pros and cons of unionization during the two days of educational sessions planned for the end of the month.

The librarians realized that they were being called upon "sooner than we would like to make a decision about faculty association membership and collective bargaining" 154 and also began to gather the information and support they would need to

${ }^{150}$ S. Jackson, oral history.

${ }^{151}$ Ibid.

${ }^{152}$ Ibid. See Chapter 2 for faculty reaction to Oliver's statements.

153 “Motions Passed at November $29^{\text {th }}$ General Meeting," CUASA News 5, no. 2 (December 1974): 1 , FN 1, Chapter 2. According to the Carleton University Data Book 1974-75, there were 608 full-time faculty working at the University. Carleton University, Carleton University Data Book 1974-75, 48, FN 3, Chapter 1.

${ }^{154}$ APLCU Council, memo to all professional librarians, December 6, 1974, in the author's possession. 
move forward as a group. Members of the APLCU council encouraged their colleagues to attend the upcoming CUASA presentations but also arranged a series of noontime information sessions for librarians on collective bargaining featuring representatives from key interest groups that could provide an alternative to CUASA. The sessions were held throughout January and February 1975 and the speakers included Elizabeth Plettenberg, the assistant to CUPE's director of education; Vic Sim, the CAUT executive secretary; Christine Baird, the president of the North York Public Library union (a CUPE local); Professor Roine from Carleton's law department; ${ }^{155}$ and Jill Vickers. They did not invite a speaker from the PIPSC as that organization had denied them membership nor did they approach anyone from the Carleton University Support Staff Association (CUSSA), which was currently involved in a membership drive and to which the librarians could potentially belong. ${ }^{156}$ At this time, the CAUT and CUPE were vying to represent faculty members in labour negotiations but Frances Montgomery still has the impression that the noon-hour information sessions simply reinforced what the librarians already believed: they were naturally aligned with professors rather than non-academic staff.

The thing was ... what group would sort of best represent the sort of aspirations of the librarians. Which group would be the most ... sympathetic because of course this is where it was so crucial for us ... If one was interested in equity, there were no procedures ... it was timing as well, because that seemed to be moving a lot faster. And I think maybe that was the decisive thing ... CUASA seemed to be far more advanced at the time than CUPE ... [and] people identified ... more with the academic staff than they did with the support staff. ${ }^{157}$

${ }^{155}$ APLCU, Minutes of the Meeting on January 2, 1975, 1, FN 148, Chapter 3; APLCU, Minutes of the Meeting on January 13, 1975, 1. APLCU, FN 148, Chapter 3; Minutes of the Meeting on February 5 , 1975, 1, FN 148, Chapter 3. Baird, Plettenberg and Sim had spoken at an IPLO-sponsored workshop held at the Ottawa Public Library October 26, 1974. Valerie Swinton, Elspeth Ross and Peggy Atherton attended this seminar. Report on IPLO Workshop: "Negotiating Options for Librarians, n.d., in the author's possession.

${ }^{156}$ APLCU, Minutes of Meeting on January 2, 1975, 1, FN 148, Chapter 3.

${ }^{157}$ F. Montgomery, oral history. 
At the same time, the APLCU committees responsible for tackling salaries and conditions of employment and work (CEW) began to gather data. Susan Jackson was the chair of the salary committee and her first major task was to conduct a staff survey. She sent out forms to each professional librarian asking for information on not only current salaries but also annual increases, a process "where the cat got out of the bag ... because nobody knew what anybody else's salary was because there was no salary structure."158 Currently individuals were hired at a given salary that appeared to be determined randomly as did the annual raises - these decisions did not seem to be made according to the principle of "equal pay for work of equal value." Not everyone was comfortable revealing their pay increase levels but Jackson was able to gather enough information by assuring participants that the survey would be "totally anonymous." "159 The results were dramatic.

The range was phenomenal ... you might have got $1 \%$ or you might have got $8 \%$. You know? And so at that point it was kind of an ah-ha moment ... there was no equity ... It was a personal relationship thing and if you were a favoured person, you got a good amount of money, if you were not a favoured person, oh well. You might be invited to move along. ${ }^{160}$

The CEW committee was kept equally busy continuing the work done earlier on the proposed IPLO standards for terms and conditions of work. These standards were now considered "minimum" required work and employment conditions and, along with the results of the salary survey, were used by the CUASA sub-committee on librarian membership in its position statement. ${ }^{161}$

\footnotetext{
${ }^{158}$ S. Jackson, oral history.

159 Ibid.

160 Ibid.

${ }^{161}$ APLCU, Minutes of Meeting on January 9, 1975, appended report from the Committee for Conditions of Employment of Work, January 9, 1975, 1, FN 148, Chapter 3.
} 
The CUASA education sessions were held at the end of January and APLCU attended a presentation by Ian McKenna from the CAUT on the membership of librarians in faculty associations. ${ }^{162}$ Despite their participation in these presentations, they were increasingly aware that there was no guarantee that the CUASA council would grant them membership - the faculty association at the University of Ottawa had "turned down" a recent request from the university's librarians to become members — and continued to keep their options open. As Valerie Swinton reported at the January 31 council meeting,

If faculty amend their constitution to enable librarians to join them, they may issue us an invitation. If we vote to join faculty, we have been advised to act as a group, and go in and share their lot, i.e., see if collective bargaining comes in. We could also maintain our own association, and if they don't proceed to collective bargaining, we could. ${ }^{163}$

However, by then the CUASA sub-committee on librarian membership had submitted its report entitled Librarians and CUASA that supported both academic status for librarians and their membership in the association and by February 14, 1975 the CUASA council had voted in favour of amending its constitution to define members as "all academic staff ${ }^{\prime 164}$ which included librarians. On February 24 the council passed the following motion:

The professional librarians were officially invited to join CUASA and it was also voted to invite those sessional lecturers who would, in accordance with the provisions of the Labour Relations Act, probably be considered full-time academic staff to join CUASA. ${ }^{165}$

The librarians now had a decision to make: would they join CUASA and participate in collective bargaining?

\footnotetext{
${ }^{162}$ APLCU, Minutes of Meeting on January 24, 1975, 1, FN 148, Chapter 3.

${ }^{163}$ APLCU, Minutes of Meeting on January 31, 1975, 1, FN 148, Chapter 3.

${ }_{165}^{164}$ CUASA Motion to Amend Constitution, February 24, 1975, in the author's possession.

165 "Council Report," CUASA News Special Edition (April 10, 1975), FN 1, Chapter 2.
} 
The next step was to hold a "soirée" off campus at the home of APCLU council member Erika Fuerst to "air" all alternatives for collective bargaining. ${ }^{166}$ The meeting took place on February 24 and the librarians had three options to debate: informal negotiations with Carleton's administration, voluntary recognition of the APLCU by university administrators and collective bargaining. If they chose collective bargaining they would then have to opt for one of six possible bargaining units and three possible bargaining agents. ${ }^{167}$ Although not all professional librarians attended what Susan Jackson refers to as the "very famous meeting," twenty-four were present including twenty paid-up APLCU members - enough for a quorum. ${ }^{168}$ In the end, the majority of those present voted in favour of collective bargaining and chose CUASA as their preferred bargaining agent (fifteen to nine). ${ }^{169}$ For Jackson, it was not so much the choice of bargaining agent that was memorable but the fact that one of the librarians presentMartin Foss — indicated that Geoffrey Briggs had offered him an "assistant librarian job" that would put him outside the bargaining unit. ${ }^{170}$

The CUASA council moved swiftly to submit its application for certification to the OLRB in March and Valerie Swinton wasted no time in distributing "little slips" so that librarians could enrol in the association. ${ }^{171}$ The OLRB gave its conditional decision on April 4, 1975. Swinton, who attended the hearing, reported to the APLCU council that the librarians had been included in the overall bargaining unit and that five positions had

${ }^{166}$ Notice of General Meeting of APLCU, n.d., in the author's possession.

${ }^{167}$ APLCU, Minutes of Meeting on February 5, 1975, FN 148, Chapter 3.

${ }^{168}$ APLCU, Minutes of the Meeting on February 24, 1975, 1, FN 148, Chapter 3. The minutes include a discrepancy in the number of librarians present. Peggy Atherton recorded both a total of twenty-three and twenty-four people present. I have opted to use twenty-four because there two references to those voting in favour and against given motions and in each case the number of voters adds up to twenty-four.

${ }^{169}$ Ibid., $1-2$.

${ }^{170}$ S. Jackson, oral history.

${ }^{171}$ F. Montgomery, oral history. 
been excluded, either because they were managerial or working with confidential materials: the chief librarian; head of technical services; head of interlibrary loans, circulation, and building facilities; head of systems; and the administrative assistant to the university librarian. ${ }^{172}$ However, no one was a full-fledged union member because the OLRB had the outstanding issues of the status of departmental chairs and a potential representation vote to resolve. As discussed in Chapter 1, the OLRB members eventually included chairs in the bargaining unit and they made the "unprecedented" decision to require a representation vote although more than the required number of faculty had already signed cards during the certification drive indicating their support for CUASA as the bargaining agent — perhaps because CUASA was setting a precedent as the first faculty association in Ontario to file for certification. By the time that vote was held on April 14, twenty-seven professional librarians had voluntarily chosen to join the faculty association and were amongst the $79.8 \%$ of CUASA members who cast ballots in the OLRB vote in favour of the association as the designated bargaining agent. Of the 481 individuals voting, some would have belonged to the group of twenty-seven APCLU members. ${ }^{173}$

Given the initial ruling by the OLRB, university senior administrators had indicated that they would be ready to negotiate as soon as the final decision was rendered and this put pressure on the librarians to prepare for potential contract negotiations. ${ }^{174}$ Over the next month and a half, Swinton and Neal Brearley were kept busy as the APLCU-elected representatives on the CUASA council and dealt with issues such as a challenge to two of the library exclusions from the bargaining unit and the APLCU

${ }^{172}$ This Week Times Two, Special Edition (Thursday, April 10, 1975): 1, FN 3, Chapter 2.

${ }_{174}^{173}$ APLCU, Minutes of Meeting on April 15, 1975, 1, FN 148, Chapter 3.

${ }^{174}$ Ibid. 
committees worked non-stop to develop salary recommendations and a coherent statement of professional work standards that would become the basis for collective bargaining. The CEW committee submitted a detailed 21-page document to the APLCU council at the end of May that outlined all the key conditions of employment and work including academic status, university government, academic freedom, professional development, rank structure, appointments and promotions. ${ }^{175}$ Prominently featured at the beginning of the submission was an article addressing the issue of academic status:

In recognition of the fact that the librarian's task of creating, assembling and making accessible the tools and materials of research is an academic function, the University shall grant academic status to all its librarians, and shall designate librarian appointments as academic appointments. ${ }^{176}$

On June 26, 1975, the OLRB issued a certificate to CUASA confirming it as the legal and sole bargaining agent for academic staff at Carleton. Although union membership did not make academic status inevitable, the librarians now had the legal right and a forum within which to negotiate this standing.

Overcoming the Resistance of Professors

When Valerie Swinton reflects back on the process of unionization, she realizes that it was not as peaceful a transition as it seemed at the time.

I think I was a real Pollyanna ... I kind of was skipping around in my little pink dress and not paying attention to the mood of the day and what was going on. Clearly there was some opposition in the library and on the campus, among the campus administrators. ${ }^{177}$

${ }^{175}$ APLCU Committee for Conditions of Employment and Work, Submission on Conditions of Employment and Work to the Council and Members of the Association of Professional Librarians of Carleton University, May 1975, in the author's possession.

${ }^{176}$ Ibid., 2.

${ }^{177}$ V. Swinton, oral history 
As previously mentioned in Chapter 1, privately senior administrators, including President Oliver, questioned the inclusion of librarians in the bargaining. Publicly, they addressed the issue in the campus-wide newsletter This Week Times Two, although their comments were not derogatory and the perception of librarians was that the opposition was not "so much actively stating it as sort of more in sorrow ... "Do you really know what you're doing" kind of tones." ${ }^{178}$ And there were certainly individual managers or administrators on campus who opposed CUASA's certification drive. Susan Jackson’s perception was that Geoffrey Briggs seemed "very unhappy" when the librarians opted to join CUASA rather than belong to a single library union for all staff. ${ }^{179}$ However, in general the reactions were understated if not "subtle" 180 and President Oliver openly expressed relief when unionization was accomplished without significant unpleasantness. ${ }^{181}$ Likewise, the librarians seem to have enjoyed a significant degree of solidarity, unlike both Carleton faculty and support staff who were experiencing divisive differences in opinion on the appropriateness of unionization within their respective groups.

There was, however, some opposition from faculty members who continued to question whether a "community of interest" existed between themselves and their professional colleagues in the library. ${ }^{182}$ In order to gain sufficient support for their inclusion in CUASA, the librarians had to make a convincing argument to the association council that the two groups did have substantive shared interests. More specifically, they

\footnotetext{
${ }^{178}$ S. Jackson, oral history

179 Ibid.

180 Ibid.

181 "Statement from the President," This Week Times Two, Special Edition (Thursday, April 10, 1975): 6, FN 3, Chapter 2.

${ }^{182}$ S. Jackson, ibid.
} 
had to frame their message in terms that would resonate with faculty. They chose to argue that librarianship was fundamentally educational in nature and that they needed to belong to a large, powerful group in order to have gain occupational status. They opted to completely suppress any reference to the gendered occupational inequalities, i.e., collective bargaining was never an issue of the status of women despite the fact that a key ally, CUASA President Jill Vickers, believed that female librarians and faculty members had a "common cause" because as women they had experienced "some really nasty stuff."183

Former Carleton University chief librarian Geoffrey Briggs still has very decided views on the unionization of librarians at Carleton. He had been trained at the University College London School of Librarianship and Archives in the late 1940s and arrived at Carleton in 1968 after a stint at the University of Calgary as deputy librarian, and with a mandate to plan a new library building and automate certain library services. ${ }^{184} \mathrm{He}$ explains "the advent of unions"- -both CUASA and the Carleton University Support Staff Association (CUSSA) - in terms of situational and economic factors as well as the leadership of then President Oliver who succeeded A. D. Dunton in 1973. As we have seen in the preceding chapter, Oliver had a very different style from the charismatic Dunton and was unpopular with many faculty, including CUASA organizers. In Briggs' opinion, unions were the result of Carleton's current financial position and the way this issue was handled by Michael Oliver, the growing acceptance of unionization in North American universities, and in the case of the library the realisation that forming a union with the faculty offered the opportunity of a more formal career structure and improved

\footnotetext{
${ }^{183}$ J. Vickers, oral history.

${ }^{184}$ Geoffrey Briggs, e-mail message to the author, November 1, 2011.
} 
salaries. ${ }^{185}$ Collective bargaining was not a change to which Briggs remembers having any "real objection" and the evidence suggests that, like President Oliver, Briggs made no deliberate attempt to obstruct the activities of either the Professional Staff Committee or the APLCU. In fact, he paid the expenses for Swinton and Ross to travel to Toronto for the "York Meeting" on collective bargaining and gave Swinton leave to attend the OLRB hearing on April 1. ${ }^{186}$ However, he does seem to have questioned the premise of academic status and the right of librarians to participate in management decisions, which he still considers to be an intrusion into the "sphere" of the university librarian. By implication, the librarians' "pursuit of this aspect of so-called professionalism" was inappropriate and might have been designed to make them "feel more like faculty members!" but did not necessarily guarantee this status. ${ }^{187}$ It is unclear whether he articulated his views in this way during the certification campaign although Susan Jackson's lingering impression is that he would have been more comfortable negotiating with a single bargaining unit such as that at the North York Public Library-the "honey" union—over which he might have more influence than multiple locals. Plus, she wonders at the timing of the promotion of a senior librarian into a managerial position that, unlike that of a departmental chair, eventually was excluded from the bargaining unit. ${ }^{188}$

Briggs was not alone amongst Canadian chief librarians in questioning the appropriateness of unionization for professional librarians. Another dissenting voice was that of Margaret Beckman, the library director of the University of Guelph Library. In 1974, Beckman argued that academic librarians should not seek an improvement in their

\footnotetext{
${ }^{185}$ Ibid.

${ }^{186}$ Professional Staff Committee, Report of York University.

${ }^{187}$ Ibid.

${ }^{188}$ S. Jackson, oral history.
} 
occupational status by attaching themselves to professors, whose goals and credentials might be similar but were not identical. ${ }^{189}$ Instead they should "achieve their status and any ensuing rights and privileges through their own merit," which meant asserting the academic nature of their work rather than claiming faculty status with its requirement for teaching and all the characteristics of belonging to Rowat's "community of scholars" such as tenure and rankings. ${ }^{190}$ She did not object to librarians belonging to faculty associations but cautioned that even that status did not guarantee that librarians would be included in a bargaining unit if the association was certified — as had happened for the librarians at St. Mary's University who were told by the provincial labour relations board that they did not share a "community of interest" with professors. Joining with support staff was also not a viable option. Given that typically administrative and clerical library staff outnumbered the librarians in the workplace, being affiliated in such a union would threaten the interests of librarians. Support staff would dominate the membership in numbers and, by implication, they would have the power to promote their interests and librarians would not (and interesting observation, light of what would have happened to Carleton librarians if they had joined CUSSA [which eventually became a CUPE local]). In Beckman's opinion, the solution to current personnel issues was for chief librarians and other library managers to abandon the "traditional hierarchy" and its attendant bureaucratic management style and become more "participatory or consultative."191

Valerie Swinton and the other APLCU council members certainly seemed to have enjoyed the support of the majority of librarians. This is in some ways unexpected since early American library union organizers notoriously faced stiff resistance from librarians

\footnotetext{
${ }^{189}$ Beckman, "Implications for Academic Libraries," 122.

${ }^{190}$ Ibid., 123.

${ }^{191}$ Ibid., 124.
} 
and historically Canadian librarians were consistently more interested in professionalization than unionization. Canadian public library librarians had only begun to unionize in the late 1950s, later than their American counterparts, with those in academic libraries trailing behind them. ${ }^{192}$ Certainly there were librarians at Carleton who openly opposed collective bargaining and seem to have been particularly concerned about the potential backlash and a "lack of harmony, and conflict with Mr. Briggs.",193 Hilda Gifford expressed concern that "we were throwing ourselves into who knew what trouble" ${ }^{, 194}$ and Pam Roberts, head of the social sciences division, ${ }^{195}$ seems to have had similar feelings throughout the period in which librarians were organizing. Roberts avoided the "preliminary meetings" of the APLCU and Frances Montgomery believes that she resigned when it became clear that the librarians were going to belong to a union. "So that was a bit of a shock ... I think that it had to do with her perception of unions and that she knew that it was going to be difficult times ahead, and so she left and went to Victoria." ${ }^{196}$ Such protest was, however, minimal and at the time that CUASA applied for certification the APLCU represented more than $50 \%$ of the professional staff despite the fact that Carleton librarians were unfamiliar with unionization. There is no evidence that they had tried to unionize in previous years and this lack of interest can be attributed in part to the generalized preference amongst North American libraries for collective action in the form of professionalization. Individually, however, their own family backgrounds and personalities undoubtedly played a role in their decision to vote in favour of joining CUASA when it became clear that the association was going to apply for certification

\footnotetext{
192 Mudge, "Collective Bargaining of Librarians," 1.

${ }^{193}$ F. Montgomery, oral history.

${ }^{194}$ S. Jackson, oral history.

${ }^{195}$ F. Montgomery, oral history.

196 Ibid.
} 
with the OLRB.

As is discussed briefly in Chapter 4, some union organizers and researchers have concluded that women are less likely to approve of unionization, particularly if their fathers or other male family members are not union supporters. However, both Susan Jackson and Valerie Swinton's attitudes seem to contradict this conclusion, as does the research on librarians and unions, suggesting that familial approval was not necessarily a pivotal factor in librarians' decision-making. ${ }^{197}$ For example, Susan Jackson's father had been a director of sales for Charles E. Frost and Company, a pharmaceutical company in Montreal, and Jackson would "chit chat" with him about the events at Carleton over the Sunday dinner table.

[He] didn't have a particularly strong pro-union position but he had a very strong pro-equity position. And he was a pretty darn good feminist for his time and age. So he was very supportive, even though he didn't really think unions were all that good. Now he worked in a commercial industry that dealt with things like warehousers and you know, quite different union environments. ${ }^{198}$

Likewise, Valerie Swinton grew up in a non-union household but she describes herself as someone who is prepared to "go out on a limb" and had been involved in a unionization effort when she worked at the University of Calgary. ${ }^{199}$

If librarians did not experience significant dissent from within their ranks or opposition from university administrators, they were certainly aware that substantive resistance could come from Carleton professors. Generally, Canadian faculty members were not convinced that librarianship was scholarly in nature and there was the recent precedent for a lack of professorial support at St. Mary's University. In Ontario, there

\footnotetext{
${ }^{197}$ Guyton, Unionization.

198 S. Jackson, oral history.

${ }^{199}$ V. Swinton, oral history.
} 
was similar opposition - as Jill Vickers had indicated in October 1974, academics were territorial regarding their benefits and did not have any real knowledge of the nature and scope of librarianship ${ }^{200}$ and she had already forewarned the librarians that some Carleton professors were not immune to this thinking. As such, the APLCU executive had to make a compelling argument to the CUASA council that professors and librarians shared a "community of interest" if they were going to be admitted into the association. To do so, their position had to be carefully framed to be meaningful to professors, particularly as the librarians were aware that there were substantive differences between the two occupational groups.

The work is not the same. The conditions of work are not the same. The criteria by which we're judged is [sic] not identical, but we have tried to move it into areas of similarity, so that wherever there is linkage it appears. So, yeah, you can't say it's identical, it's not. But there is certainly a very strong community of interest and practice. ${ }^{201}$

As such, they had to make strategic decisions not only about what should information included in their argument but also what should be excluded.

The librarians' position on faculty status and membership in CUASA was contained in a submission made to the association's membership subcommittee. Unlike other currently circulating documents on academic status (which were long and detailed) authors Valerie Swinton and Neal Brearley - the library representatives on the committee-wrote a short statement that focused on three key points: the educational nature of their work; the shared interests of librarians and faculty; and the need for a powerful ally. The preamble to the document was taken directly from the Association of

\footnotetext{
${ }^{200}$ Professional Staff Committee, Report of York University Meeting. It is unclear whether Jill Vickers was at the September meeting. Swinton and Ross's notes imply that she was but a report from Cal Evans on the meeting does not include her as one of the attendees although Phil Hull was there.

${ }^{201}$ S. Jackson, oral history.
} 
College and Research Libraries (ACRL) article on faculty status that appeared in the journal College and Research Libraries in 1974: "As the primary means through which students and faculty gain access to the storehouse of organized knowledge, the university library performs a unique and indispensable function in the educational process."202 Librarianship could not be thought of simply as the provision of an "add on" service or routine, clerical work. Instead, librarians were integral to teaching and research at the university or, as per the Carleton University Act, "the advancement of learning" and the "dissemination of knowledge."203

Based on this premise, Swinton and Brearley argued that librarians and professors had common concerns. Both groups had the right to academic freedom which was essential if they were to use their "professional judgment" to make decisions critical to their work: librarians to choose and make available materials for the collection; professors to teach and do research; together to participate in institutional decisionmaking. They also should have opportunities for career development and be adequately paid. Given the nature of their work and these shared interests, the librarians were entitled to academic status but were not recognized institutionally and were in fact status-less, caught in limbo between faculty and support staff. The rapidly looming possibility of certification for CUASA forced the librarians to quickly address the issue of collective bargaining and, in particular, the choice of the most suitable bargaining unit. As a small group, they were aware that they did not have either the strength of numbers or the expertise to successfully advocate on their own behalf for improved occupational status. An alliance with faculty would empower them to negotiate with the university

\footnotetext{
202 "Statement on Faculty Statues of College and University Librarians," College and Research Libraries 35, no. 2: 26 (1974): 26, in the author's possession.

${ }^{203}$ Carleton University Act, FN 13, Chapter 2.
} 
administrators for the recognition and academic standing they wanted whereas one with support staff would not and they had five specific objectives: participation in library and university governance; economic benefits including "realistic" salaries and rankings tied to those of faculty; improved conditions of work such as appointments and promotions equivalent to those of faculty; and finally both study leave and access to research funds. $^{204}$

Swinton and Brearley's argument was not nearly as elaborate as that developed in the AALO brief to OCUFA, the ACRL statement or the CAUT/CACUL guidelines that were published later that spring and to which Swinton had contributed. In fact, their positioning statement seems almost anti-climactic given the real need to gain faculty consent at a time when such support was potentially doubtful. Swinton and Brearley may very well have not felt the need to make a stronger statement. Despite the fact that CUASA members at large may not have recognized the shared occupational interests between themselves and the librarians, there were members of the CUASA council who did and seem to have been influential allies prior to the final vote on membership. For example, Professor Andrew Brook was one of the two faculty representatives on the membership subcommittee. As we have seen earlier, Brook was supportive of collective action. As such, he seems predisposed to understand the librarians' perception that "they weren't getting a very good deal out of the university"; it made sense that they needed greater input into their terms and conditions of work because "the librarians had no governance documents at all. I mean their careers were run at the whim and fancy of the

\footnotetext{
${ }^{204}$ Neil Brearley and Valerie McDougall, Librarians and CUASA: A Statement to the Sub-Committee Exploring the Membership of Librarians in CUASA, 1975, in the author's possession.
} 
university librarian." ${ }^{205}$ Such support from professors at the committee level undoubtedly was helpful in drafting a statement that would resonate with other faculty members.

Arguably the most powerful supporter was CUASA president Jill Vickers who, according to Swinton, "encouraged us, included us and persuaded the faculty association that it was a good fit for us to be part of their organization. ${ }^{206}$ As we saw in Chapter 2, she seems to have followed in her father's "left-wing" political footsteps-certainly enough to refuse to sign the regent's oath of allegiance as a graduate student at the State University of New York (Buffalo) and to run as an New Democrat Party candidate in the $1970 \mathrm{~s} .{ }^{207}$ She arrived at Carleton in 1969 with an interest in collective action and a sensitivity to the issues being raised by Canadian feminists at that time. ${ }^{208}$ Some of her own experiences as a young, female faculty member were decidedly unpleasant and her concerns about campus-wide problems such as sexual harassment, a lack of day care and no maternity leave gave her "common cause" with the librarians- - "because the librarians were mostly women., ${ }^{209}$ Apparently Vickers had not only the respect of the librarians but of her CUASA colleagues as well—certainly she seems to have had no difficulty in getting approval to form the membership subcommittee-so her endorsement of membership for librarians might very well have been as or more compelling than any written argument the librarians could have made on their own behalf.

The brevity of the APLCU statement was due to a conscious decision by Brearley and Swinton to exclude certain issues and details from their document that might not be

${ }^{205}$ Ibid.

${ }^{206}$ V. Swinton, oral history.

${ }^{207}$ J. Vickers, oral history. According to Vickers, "in order to be employed by the state university in New York at the time you had to swear that not only were you not a member of the communist party but that none of your family was and I wasn't going to/able to swear to that."

${ }^{208}$ Ibid.

${ }^{209}$ Ibid. 
considered meaningful to professors or worse, provoke opposition. In late January they reported to the APLCU council that they had been advised by their faculty colleagues on the subcommittee to "play down" any reference in the submission to the teaching function of librarians, which had been included in the AALO document Elaboration on the Fourteen Points in Answering the Question 'What Exactly is it We Want as University Librarians? ${ }^{210}$ Although Brearley and Swinton did not elaborate on the reasons for avoiding the issue of instruction, it is possible that this reflected a belief on the part of the faculty committee members that their professorial colleagues might question the teaching role of librarians, a belief that certainly contradicted Dewey's original assertion that "the library was school and the librarian a teacher." Nor did Swinton and Brearley discuss the educational credentials of librarians, maybe because they wanted to avoid any suggestion of an equivalency between the academic backgrounds of librarians and faculty - unlike librarians at an AALO meeting that Frances Montgomery attended on in early January. ${ }^{211}$

Most glaring is the lack of any reference to occupational inequities, and in particular the status of women, even though some Carleton librarians, such as Swinton, did frame workplace issues in terms of inequality, at least off the record. "Oh, we all read Germaine Greer and all the seminal feminist stuff. And we ... were talking about things like $99 \%$ of the employees in libraries are female but $90 \% \ldots$ of the leaders in libraries are male and how fair is that?"212 The omission does not surprise Jill Vickers. She already recognized that although women from academic units across campus were motivated to get heavily involved in the association as a result of "gender agenda," equity for women was not necessarily a top priority for their male colleagues. Instead of raising issues of

\footnotetext{
${ }^{210}$ APLCU, Minutes of Meeting on January 31, 1975, 1, FN 148, Chapter 3.

${ }^{211}$ Ibid.

${ }^{212}$ V. Swinton, oral history.
} 
day care and lower starting salaries for women, CUASA organizers ran a successful certification campaign on the premise that professors needed "contractual rules of the game" to protect themselves given that jobs were being threatened by a president who seemed ready to cut jobs in response to the university's financial crisis. ${ }^{213}$ By avoiding these gender issues in their position statement, Swinton and Brearley were simply being consistent with the strategic approach of the broader unionization campaign. They were also acknowledging the unspoken understanding that when some professors questioned the "community of interest" with librarians, they were really asking "how can women's work be the equivalent to men's work?"

Between mid-January and the beginning of February, the subcommittee had several telephone conversations and one face-to-face meeting to discuss the issues related to librarians' membership. On February 3, they formally approved Swinton and Brearley's submission and sometime over the next three weeks, they submitted a final report to the CUASA council. ${ }^{214}$ In their report, the committee members focused on the main objectives raised in the APLCU statement and stated succinctly that, based on the assessment of the two CUASA representatives, they found no "base-level disagreements" between the ambitions of the professors and librarians - in fact "these desires seem consistent with —indeed, complementary to- the aims of CUASA." ${ }^{215}$ On the strength of these findings and with little or no fanfare, the CUASA council voted to admit librarians into the association less than six weeks after the committee had begun its work.

213 J. Vickers, oral history.

${ }^{214}$ APLCU Collective Bargaining Committee, Statement, February 5, 1975, in the author's possession.

215 J.A. Brook, B. Wand, Valerie McDougall and Neil Brearley, CUASA Report on the SubCommittee on Membership of Librarians, n. d., in the author's possession. 


\section{Conclusion and Epilogue}

The minutes of the APLCU meeting on Friday, July 11, 1975 show that "J. King and F. Montgomery are to prepare the press release to publicize our unionized status." 216 The OLRB had made its final ruling on June $18^{217}$ and by the time the press release went out members of the APLCU were already in discussions with Jill Vickers and other CUASA representatives on initial bargaining positions. ${ }^{218}$ Formal talks with the university's negotiating team began on July 14 and over the next four months, the librarians "got busy" writing their own bargaining positions on key terms and conditions of work such as salaries, appointments, promotions, and rankings. ${ }^{219}$ Their goal was:

to create language that would provide a reasonably equitable and transparent set of processes under which peoples' working lives would be regulated. I mean essentially it was the transparency, right? Because that was what we discovered, was that there was no transparency, that it was total murk. ${ }^{220}$

The librarians might not have encountered significant resistance prior to certification but they definitely faced overt opposition to changes in their working conditions during the first round of collective bargaining. CUASA negotiators had difficulty reaching agreement with "the university on the librarians," and one of the key sticking points was salary levels. ${ }^{221}$

Eventually, however, they reached a settlement that legally encoded their status as academic staff and provided "radical" improvements in their working conditions. ${ }^{222}$ According to Andrew Brook, the increase in salaries alone was spectacular. "In the end,

\footnotetext{
${ }^{216}$ APLCU, Minutes of Council Meeting on July 11, 1975, FN 148, Chapter 3.

${ }^{217}$ Collective Agreement between Carleton University and Carleton University Academic Staff Association, December 11, 1975 to June 30, 1977 (hereafter CUASA-CU Agreement), Article 3, Recognition, in the author's possession.

${ }^{218}$ APLCU, Minutes of Council Meeting on July 11, 1975, FN 148, Chapter 3.

${ }^{219}$ S. Jackson, oral history.

${ }^{220}$ Ibid.

${ }^{221}$ A. Brook, oral history.

${ }^{222}$ S. Jackson and F. Montgomery, oral history.
} 
the [chief] librarian was not willing to cap salaries ... let alone reduce salaries of his favourites. And so the librarians as a whole got an average $28 \%$ increase to bring everybody else up to the level that his chosen few were earning." 223 These higher levels were welcome not just because they provided additional income, particularly during an economic period of high inflation, but also because of past inequities. In the case of Frances Montgomery, her actual starting salary had been lower than originally promised in her verbal contract with Geoffrey Briggs.

Mr. Briggs [had] ... named a figure which was close to what they were being paid at the National Library, and I think that that was something like, I don't know, $\$ 10,000$ or $\$ 11,000$ at the time. And so we agreed that that's what it was. And then in my letter that I got from the president ... it was something like $8 \ldots$ So it was not the figure that ... I thought that we had agreed on. ${ }^{224}$

Higher pay scales only have not the only benchmark of equity or status. Unlike colleagues at other universities such as the University of Toronto, prior to unionization the librarians did not have a system of ranking or promotions that would allow them to have what Montgomery calls "some kind of career progression.",225

It was very hard for people because sometimes they were forced to apply for jobs that they weren't terribly interested in just so that they could become a "three" for example so even if you were ill suited to becoming the assistant head of cataloguing ... you would apply because it was the only thing that was going that would have made you a three"... So you had to wait for somebody to pop off. Or as they say in Yorkshire, 'pop your clogs'."226

The first contract introduced both a four-level ranking system based on a number of factors including educational attainment that was the basis for a promotional structure that offered new opportunities for career growth through progression through the ranks rather than strictly advancement via movement into managerial positions. There were

\footnotetext{
${ }^{223}$ A. Brook, oral history.

${ }^{224} \mathrm{~F}$. Montgomery, oral history.

${ }^{225}$ Ibid.

${ }^{226}$ Ibid.
} 
also clauses related to peer evaluation, library governance and the rights and responsibilities of professional librarians as "academic staff.,"227

As such, unionization proved to be an effective strategy for regulating terms and conditions of work. The librarians achieved significantly positive changes to their workplace in a relatively short space of time and the contractual language to explicitly place them in the same occupational group as faculty members. However, the designation of librarians as academic staff did not necessarily confer full faculty status, particularly if that standing was measured by participation in university governance. The first contract included provisions for the university library committee that would include the university librarian, eight elected librarian representatives and five faculty members chosen by the Senate executive committee. ${ }^{228}$ According to Susan Jackson, the librarians had also asked for representation on the Senate because "in the 60 s and 70 s ... there was this sort of sense that it was an important thing to participate in." ${ }^{229}$ Her experience has been, however, that while the university librarian was appointed to the Senate ex officio,

The librarians can't actually have representation on Senate, which is interesting because of the Carleton University Act ... because ... in many institutions that's possible. But because of the language in the text and they didn't want to open the text because it's a provincial act, because they were afraid of other changes that the province might then want. ${ }^{230}$

The perceived unwillingness to revise the legislation clearly rankles a bit even though she recognizes that "we probably have a pretty good deal."231 The Senate was (and is) an icon of collegial activity and inclusion represented an opportunity for "more interaction with

${ }^{227}$ CUASA-CU Agreement, Article 11 (Professional Librarian Employees), Article 15 (Rights and Responsibilities) and Schedule 2 (Memorandum of Agreement Concerning the Assessment of Positions in the Library).

${ }^{228}$ Ibid., Article 11.2.

${ }^{229}$ S. Jackson, oral history.

${ }^{230}$ Ibid.

${ }^{231}$ S. Jackson and F. Montgomery, oral history. 
faculty. ${ }^{232}$ A review of the Carleton University Act some time later had recommended that it be revised and apparently it had been to incorporate instructors but "we were not able to be fluffed in.,233

Similarly, the choice of CUASA as a bargaining agent did not mean that either the status of librarians or the professors had become trade unionists. Both groups had deliberately rejected the opportunity to join CUPE during the certification campaign because it represented a form of union with which they did not want to be associated. As discussed in Chapter 1, CUASA has remained an independent association, affiliated with CAUT rather than the Canadian labour movement, and more in the tradition of library associations such as the OLA than that of trade unions.

In 1975, Theodore Lewis Guyton published the results of his research on the formation of public library unions in an ALA monograph entitled Unionization: The Viewpoint of Librarians. Guyton had developed an explanatory model that incorporated a number of variables that could determine library unionization including occupational and personal characteristics such as age, sex and race as well as "economic position," i.e., key terms and conditions of work including earnings and fringe benefits. ${ }^{234} \mathrm{He}$ distributed an extensive questionnaire to 715 professional librarians ${ }^{235}$ working at public libraries in southern California and, based on the input of 460 respondents, concluded:

${ }^{232}$ Ibid.

${ }^{233} \mathrm{~S}$. Jackson, oral history. I have not been able to find a record of this later review. The last amendment to the Carleton University Act was done in 1968.

${ }^{234}$ Guyton, Unionization, 7. Guyton had a response rate of $64 \%$ based on 460 responses; 715 questionnaires were distributed.

${ }^{235}$ Guyton defined professional librarians as "one who has completed a course of study in a graduate library school. This usually means at least five years of college: four to meet the requirements of a bachelor's degree and a fifth year of more of specialized study in library science, after which a master's degree is conferred. In actuality, many public librarians attain a professional position through experience and without a degree in library science." He also defined unionization as follows: "If a library staff determines either through a formal representation election or through an informal vote that they desire to 
The goal of unionization is to enhance the "professional" status of the job in order to achieve status equivalent with expectations. Expectations are measured by the amount of professional training and status of administrators. To this end, library unionization is more of an expression of a status than a class ideology since there is no apparent rejection of administrative authority or attempt to displace the administrative hierarchy. ${ }^{236}$

Guyton's analysis seems to be compatible with the experiences of librarians at Carleton University. As professionals, they were dissatisfied with their current status as reflected in current working conditions, which they viewed as inequitable, as well as the lack of recognition for their expertise and contributions to teaching and research at the university. They were not interested in changing the structure of institutional governance; rather they wanted to participate more fully in both academic decision-making as well as that related directly to policies and procedures within the library. Moreover, they did not frame either the desire for academic status or the decision to support collective bargaining in terms of gender or the status of women, which is consistent with Guyton's argument that contrary to popular belief, female employees were not "a crucial obstacle to unionization.",237

Sex, however, is not gender. Although the librarians did not openly acknowledge the "feminization" of their occupation and the "double ghetto" reality of low wages and the overabundance of male leadership, their status was clearly influenced by traditional "sex roles" which undoubtedly underpinned the resistance of some male faculty members to the idea that librarianship was academic in nature and shared a "community of interest" with professorship — no matter how politely this opposition was expressed.

Professionalization had facilitated the ability to regulate occupational boundaries to some degree but it had failed to break through these cultural barriers. Unionization did not

form or join an organization to act as their representative, then they are expressing a desire for collective action and will be considered "unionized." Guyton, Unionization, 2-3.

${ }^{236}$ Ibid., 174.

${ }^{237}$ Guyton, Unionization, 1. 
immediately result in an "eruptive" break in these attitudes—according to Jill Vickers, female professors were still expected to type in the late 1970s and academia persisted in being a "chilly climate" for women well into the 1990s — but over time it did produce such attitudinal changes. ${ }^{238}$ Susan Jackson thinks fondly of one particular professor whose moral stance changed over time.

It was very sweet, there was a very nice German professor who was very very confused with why librarians would have anything to do with CUASA at all. And I was at one meeting one evening ... and so he says, "You know, with due respect ... I really really don't understand why we have librarians ... when he retired he sent me a lovely letter of apology saying ... he understood what a valuable resource the librarians had been to CUASA after seeing them operate over the years ... He was embarrassed that he had to say this in public ... but he felt it so deeply. ${ }^{239}$

The United Nations declared 1975 International Women's Year and chose Australian singer Helen Reddy's hit song "I am Woman" as the anthem for the year. Reddy had caught the mood of militancy felt by many women around the world in her opening lyrics: "I am woman, hear me roar, in numbers too big to ignore. And I know too much to go back and pretend." The Carleton librarians were relatively few in number, but they were mighty enough to succeed that year in their collective efforts that year to introduce more equitable labour practices into their workplace — they really struck a "honey" of a deal.

${ }^{238}$ Vickers and Adam, but can you type?; The Chilly Collective, eds. Breaking Anonymity. The Chilly Climate for Women Faculty (Waterloo, Ontario: Wilfrid Laurier University Press, 1995).

${ }^{239}$ S. Jackson, oral history. 


\section{Chapter 4 Not to be "Squeezed Out": The Carleton University Support Staff Union Certifies}

\section{Introduction}

Although support staff received certification for their staff association after the Ontario Labour Relations Board (OLRB) Carleton University Academic Staff Association (CUASA) ruling was delivered, they were the first of the three employee groups to attempt to unionize. Library staff had tried to organize a CUPE local in late 1972 without success and then the clerical, administrative and technical support employees who belonged to the Carleton University Support Staff Association (CUSSA) began their collective efforts to improve working conditions in 1973. Pat Finn, an organizer for the CUSSA, describes the process as "fractious": young women committed to "equal pay for work of equal value" squaring off against older women convinced that they did not need this form of protection as well as male technicians who were either afraid of lowering their wages if they aligned themselves with their female colleagues or wanted voluntary recognition rather than unionization. ${ }^{1}$ Initially those leading the union drive were able to mobilize support for collective action on the issue of the "workers" plight," that is to say low wages and benefits, particularly relative to those in the federal civil service. However, while many Carleton support staff agreed that their compensation package needed improvement, material gains were not enough to garner the number of members needed to meet the OLRB requirement of 55\% of members in the bargaining unit. $^{2}$ Then the faculty and librarians voted to certify their staff association in June of

\footnotetext{
${ }^{1}$ Pat Finn, retired employee, Carleton University Academic Staff Association, in oral history interview with Sylvia Gruda and the author, March 22, 2011.

2 An Act to Amend the Labour Relations Act, R.S.O. c76. See Chapter 2 of this thesis for explanation of the representation vote. The 1970 version of the Labour Relations Act was in force when CUASA certified but was amended and granted assent on July 18, 1975. Thus the new percentages applied to the CUSSA certification application.
} 
1975. Over the next nine months, CUSSA leaders were able to capitalize on the deeply rooted understanding amongst support staff that they occupied a lower rung on the campus occupational ladder than faculty members. With unionization, academic staff had strengthened their position as the most powerful employee group at the university and many non-academic clerical, administrative and technical staff realized that they would need the "clout" of collective bargaining just to maintain their current standing and not be "squeezed out." By the fall of 1975, over 500 support staff had joined CUSSA and in March of 1976, the OLRB granted the association certification as the bargaining agent for Carleton support staff. ${ }^{4}$

This chapter explores the evolution of Carleton University support staff from being an unorganized group of employees working in a variety of occupations to becoming members of a legal bargaining unit. Many "Old Carletonians" were professors or senior administrators such as the chief librarian Hilda Gifford, but this group also included a large number of single and married women who had been hired in increasingly large numbers between 1942 and the late 1950s to do the "office work" deemed essential to the operation of the university. Although their participation in the paid workforce reflected a significant transformation of the Canadian labour market towards a larger proportion of white-collar workers which occurred half a century earlier, these Carleton employees did not frequently identify themselves as part of a homogenous occupational group — as did faculty and librarians — and there is little evidence that they had supported

\footnotetext{
${ }^{3}$ P. MacRae, oral history.

${ }^{4}$ The original OLRB ruling of March 4, 1976 included 780 Carleton employees in the CUSSA bargaining unit. On March 11, 1976, Pat Finn sent a notice to support staff that, after negotiations with university administrators, 656 members would be included in the union. Ontario Labour Relations Board, Ontario Labour Relations Board Report, Applications Disposed by the Ontario Labour Relations Board during March 1976 (Toronto: March, 1976), 19.
} 
collective labour activism. In the mid-1960s, the nature of this group began to change significantly. The change was partly the product of a formal job evaluation process introduced by senior managers that created two distinct non-academic categories of support work: administrative and technical. Amongst the administrative employees was a new cohort of workers who were influenced by the social justice politics of the period, including those of the labour and women's movements. These movements emphasized issues of workplace status and gender inequality. By the mid-1970s, clerical, administrative and technical employees had embraced the official moniker of "support staff' in recognition of their relative employment status on campus. Ultimately the political realities of their position led to sufficient support for collective action to allow CUSSA organizers to apply to the OLRB for certification. Consistent with the experiences of professors and librarians, success was contingent to some extent on suppressing gender issues - this could not be a campaign that was openly and primarily about "women's rights" despite the fact that the majority of support staff were women whose employment status was determined by the consistent social undervaluing of their work relative to that of their male co-workers.

\section{Creating An Identity: "Our Work is Necessary and Requires Skill"}

Today, retired university secretary Bette Smith can still feel angry about the low occupational status of clerks and secretaries in the 1970s. She certainly felt strongly enough to publicly challenge University of Toronto professor Edward Shorter's dismissal of office jobs as unskilled in a letter she wrote to the editor of the Canadian women's 
magazine Chatelaine in April 1977. ${ }^{5}$ Shorter had published an article in the national Canadian magazine the previous month, entitled The Dark Side of the Sexual Revolution. Left-Behind Women, in which he suggested that newly divorced women looking for work should be practical.

Get a skill you can market. Nothing makes a person feel more useless than the knowledge that you can't get a job at anything except waitressing or typing some idiot's letters. Try night courses at cooking school, or furniture-making or polish up your French. Any of these things - if you're ditched - might lead to some interesting work. ${ }^{6}$

Smith was offended by this characterization of certain forms of the work done by many

women as meaningless and uninteresting and said so in her response, which was

published in the magazine's "Letters to the Editor" column the following month. She took Shorter to task:

Waitresses, secretaries, clerks, factory workers - all of us employed in so-called menial jobs - are aware that for years, we've been underpaid for labor essential to the world's routine day-to-day business. Our work is necessary and requires skill. ${ }^{7}$

Smith had begun her career in the early 1970 s as a junior secretary at Carleton and undoubtedly some of her university contemporaries, such as Pat Finn, then a buyer in the purchasing department, shared her opinion. ${ }^{8}$ They might have agreed that the complexity of their work was different from that of academic staff and their workday more regimented, but they did not believe that their jobs were inherently tedious or simple;

\footnotetext{
${ }^{5}$ Gertrude Joch Robinson defines Chatelaine as a women's magazine in her article "The Media and Social Change: 30 Years of Magazine Coverage of Women and Work (1950-1977)," Atlantis 8, no. 2 (Spring 1983), 82.

${ }^{6}$ Edward Shorter, “The Dark side of The Sexual Revolution. Left-Behind Women," Chatelaine, March 1977, 56.

7 Bette Smith, "Left-behind Women," The Last Word is Yours (letters to the editor), Chatelaine, April 1977, 5.

${ }^{8}$ P. Finn, oral history. Patricia (Pat) A. Finn was married when the support staff began to unionization and appears in many original documents as Patricia, P.A. or Pat Chartier. At the time of the oral history interview, her last name is Finn and this name will be used throughout this thesis except for documents she authored during the certification campaign, where her name at the time will be used.
} 
they contributed in meaningful and visible ways to achieving the educational mandate of the university. Likewise, Carleton administrators had recognized from the early college days that "office work" was essential to the successful operation of the academic corporation, even though institutional personnel practices contributed to a gendered occupational hierarchy that created systemic inequality between men and women and facilitated both the unionization of support staff as well as conflict within this employee group during the certification campaign.

On June 18, 1942, when Carleton College's president Henry Marshall Tory convened the inaugural meeting of the Board of the Association for the Advancement for Learning in Ottawa at the Chateau Laurier, one of the issues he asked the governors to address was the appointment of an "Assistant Secretary ... upon whom the main work of the College would fall." ${ }^{\prime 9}$ Board members clearly understood the real need for secretarial support because at the next meeting, held on July 10, it was reported that Miss J.M. Jost had been hired to fill this position and was to be paid $\$ 125$ per month. ${ }^{10}$ Then on September 1, Dorothy Wardle became the "College secretary," Carleton's first full-time employee, while shortly afterwards Dorothy Povat joined Carleton as a "permanent stenographer." ${ }^{11}$ Over that first academic term, the courses offered at the new college proved to be so popular that Tory was able to report that over 700 part- and full-time

\footnotetext{
${ }^{9}$ OAAL, Minutes of the $1^{\text {st }}$ Meeting of the BOG, June 18, 1942, 1, FN 1, Chapter 1. From 1943 to 1952, the Ottawa Association for the Advancement of Learning has legal responsibility for Carleton College. In 1952, the provincial government passed a private member's bill and chartered Carleton College and the governing body for the college became the Board of Carleton College. OAAL, Minutes of the 70th Meeting of the BOG, May 15, 1952, FN 1, Chapter 1.

${ }^{10}$ OAAL, Minutes of the $2^{\text {nd }}$ Meeting of the BOG, July 10, 1942, 1, FN 1, Chapter 1 . There is not record in these minutes of whether Miss Jost was hired on a full- or part-time basis.

${ }^{11}$ Dorothy Wardle, Reminiscences (a handwritten account of employment at Carleton), 2-3, Don McEown fonds, ACC-No. 2000-05 A-278, Carleton University Library Archives, Carleton University. Although Dorothy Povat was "permanent," Wardle also related in this account that Povat worked full-time during the day for the federal government and in the evenings for the college.
} 
students had registered on November 6, and, as such, the "growth of the College made full-time office service necessary."12 In the early years, college administrators kept the number of "paid office assistants" to a minimum, and hired part- as well as full-time staff - perhaps due to financial constraints. This was to remain the pattern for meeting clerical, administrative and technical staffing requirements. As the college grew, over the fifteen years, ${ }^{13}$ and with it the need to "employ extra help" as a result of the "pressure in the office."14

During the first phase of Carleton's development from 1942 to 1958 , nonacademic staff members were hired to fill a progressively varied collection of jobs, and this fragmentation seems consistent with that of other corporate offices in both the public and private sectors, including the federal government in Ottawa. ${ }^{15}$ Initially, Miss Jost's job might have been thought of as a "junior" clerical position, perhaps requiring her to do general office work such as handling correspondence (e.g., typing and filing documents ${ }^{16}$ ) and answering the telephone. Almost immediately, however, both more specialized and senior positions began to be filled, signalling the development of an occupational hierarchy with greater complexity. ${ }^{17}$ Dorothy Wardle acted as President

${ }^{12}$ OAAL, Minutes of the $5^{\text {th }}$ Meeting of the BOG, November 6, 1942, 1, FN 1, Chapter 1.

${ }^{13}$ OAAL, Minutes of the $6^{\text {th }}$ Meeting of the BOG, January 8, 1943, 2, FN 1, Chapter 1.

${ }^{14}$ OAAL, Minutes of the $19^{\text {th }}$ Meeting of the BOG, December 20, 1945, 2, FN 1, Chapter 1.

${ }^{15}$ See Morris Altman and Louise Lamontagne, "On the Natural Intelligence of Women in a World of Constrained Choice: How the Feminization of Clerical Work Contributed to Gender Pay Equality in Early Twentieth Century Canada," Journal of Economic Issues 4 (December 2003), 1045-74; John Taylor, Ottawa. An Illustrated History (Toronto: James Lorimer \& Company and Canadian Museum of Civilization, 1986), 120.

${ }^{16}$ Ibid. Altman and Lamontagne provide a general description of clerical work in the 1920s that included positions such as: general clerks; typists; dictating machine transcribers; stenographers; bookkeepers; computing, billing and related machine operations; file clerks; secretaries supervisors; check proofers; card punchers; telephone operators; mail order clerks etc. p. 1057. See also May Hoyle's oral history in Patricia Bird, "Hamilton Working Women in the Period of the Great Depression," Atlantis 8, no. 2 (1982): 132-33.

${ }^{17}$ Bryan Dewalt, "Men, Women and Machines: Time Management and Machine Dictation in the Modern Office," Material History Review 52 (Fall 2000), 19. 
Tory's assistant and had a range of duties that included driving him to meetings in his "much-loved Packard" automobile, working closely with faculty members on registration and helping with the planning of the commencement ceremonies—duties which could require her, like the president, to use the stenographic services of Miss Povat. ${ }^{18}$ Four months later, Tory had identified the need for the skills of a bookkeeper and in 1944 the board approved the hiring of a secretary specifically to be responsible for the college records. ${ }^{19}$ The Carleton Board members also discussed the creation of a library within the first year of operation. Over the next few years, donations of books began to arrive and in 1946 "Miss Jones" was assigned the task of receiving and presumably managing the growing collection so that it could be accessible for students and faculty. ${ }^{20}$ At the end of the 1950s, the office group became even more heterogeneous and stratified as college administrators employed higher-ranking secretaries and bookkeepers in addition to typists, stenographers, machine operators, statistical as well as purchasing clerks and a variety of library assistants.

The Board minutes between the late 1940s and late 1960s regularly recorded the credentials of "instructional" staff, reflecting their concern that they were hiring high quality academic employees during the evolution of Carleton from college to university. In contrast, they did not note the education or experience that qualified office staff for employment—perhaps assuming that jobs which required a general education or limited specialized training did not need their scrutiny to ensure institutional success. They could

\footnotetext{
${ }^{18}$ Wardle, Reminiscences, 3-5.

${ }^{19}$ OAAL, Minutes of the $5^{\text {th }}$ Meeting of the BOG, November 6, 1942, 2, FN 1, Chapter 1; and OAAL, Minutes of the $9^{\text {th }}$ Meeting of the BOG, September 15, 1944, 2, FN 1, Chapter 1. Neatby and McEown, Creating Carleton, 16.

${ }^{20}$ OAAL, Minutes of the $27^{\text {th }}$ Meeting of the BOG, November 6, 1942, 2, FN 1, Chapter 1. See also Don McEown, Interview with Elizabeth Bennett, Don McEown fonds, ACC-No. 200-05 A278, Carleton University Library Archives, Ottawa, Ontario.
} 
count on the fact that the standard since the 1930s in all Canadian provinces had been for "business skills" to be taught in public commercial high schools in order to prepare students who were not going to university for the labour market. ${ }^{21}$ In the late $19^{\text {th }}$ century, bookkeeping, penmanship and business law were amongst the core competencies taught to a limited number of students, initially in private business colleges and soon in public schools to prepare those destined for "genteel" and respectable jobs in commercial offices. $^{22}$ By the 1920 s, curricula had changed across the country in part as a result of a growing demand for more young people who had the training and technical skills needed for employment in the trades and business. ${ }^{23}$ The respectability of such work started to diminish as practical courses such as typing, stenography, bookkeeping and advertising were added to economics and business mathematics as the courses required for students in commercial programs. ${ }^{24}$

Accordingly, in the late $19^{\text {th }}$ century Ottawa, students taking training for clerical work in the civil service or business attended private business colleges. Over the next thirty years, these programs were absorbed into the curriculum at the public high school, Lisgar Collegiate, before being transferred to the newly opened Ottawa High School of Commerce in $1929 .{ }^{25}$ Although high school attendance in Canada increased exponentially between 1900 and 1940, access to these programs was not guaranteed;

\footnotetext{
${ }^{21}$ Robert M. Stamp, “Canadian High Schools in the 1920's and 1930's: The Social Challenge to the Academic Tradition," Historical Papers/Communications Historiques 13, no. 1 (1978): 90.

${ }^{22}$ Nancy S. Jackson and Jane S. Gaskell, "White-Collar Vocationalism: The Rise of Commercial Education in Ontario and British Columbia 1870-1920," Curriculum Inquiry 17, no. 2 (Summer 1987): 178-79.

${ }^{23}$ Ibid. See also Paul A. Moreland, A History of Business Education (Toronto: Pitman Publishing, 1977) and Stamp, "Canadian High Schools," 78.

${ }^{24}$ Moreland, ibid., 135, gives the example of the Ontario Vocational Education Act of 1921.

25 Ibid., 142.
} 
even non-university bound students were expected to meet certain academic standards. ${ }^{26}$ Evelyn Aldridge, who was hired as "Secretary to the Administrative Assistant" at Carleton in $1959,{ }^{27}$ graduated from Ottawa's High School of Commerce during the 1930s and she had to "write tests" in order to be admitted. ${ }^{28}$ Moreover, if college governors assumed that office staff only had such high school diplomas in business-related courses, they were mistaken. Some office staff arrived at Carleton with other qualifications, including university degrees. Jean Loates, for instance, a "student personnel officer" in the $1950 \mathrm{~s},{ }^{29}$ had received a teaching certificate from the Regina Normal School $^{30}$ before completing a Bachelor of Arts at Carleton in $1956,{ }^{31}$ while just months before starting at Carleton, Dorothy Wardle had graduated from Queen's University with a Bachelor of Arts in $1942 .{ }^{32}$ In addition, office personnel could arrive at Carleton with much experience from elsewhere. Wardle was a new graduate with organizational and office experiences gained through her involvement in student activities while she was at Queen's, which included being elected as the first female president of the Alma Mater

${ }^{26}$ Christopher J. Anstead and Ivor F. Goodson, "Subject Status and Curriculum Change: Commercial Education in London, Ontario, 1920-1940," Paedagogica Historica 29, no. 2 (1993): 459; and Stamp, "Canadian High Schools," 77.

${ }^{27} \mathrm{CU}$, Minutes of the $123^{\text {rd }}$ Meeting of the BOG, October 29, 1959, 5, FN 1, Chapter 1.

${ }^{28}$ Evelyn Aldridge, retired employee, Carleton University, in oral history interview with the author, May 17, 2011.

${ }^{29}$ Carleton University, 1999-2000 Undergraduate Calendar, Bursaries, Jean A. Loates, Bursary, accessed October 20, 2013, http://www3.carleton.ca/cu9900uc/awards/Bursaries.html.

${ }^{30}$ Marvin Schreiber, "Campus Close-up (Jean A. Loates," The Carleton, November 22, 1951, 4, FN 373, Chapter 2. Loates was also awarded an honourary degree by the Carleton University Senate in 1977, accessed November 20, 2013, http://www1.carleton.ca/senate/honorary-degrees/honorary-degreesawarded-since-1954.

${ }^{31}$ Carleton College, Convocation Booklet, May 18, 1956: 4.

${ }^{32}$ Wardle, Reminiscences, 1 . It is not clear, though, if they were over qualified or if the requirements for the job were higher than the governors might have assumed. 
Society in $1941^{33}$, while Loates had taught in Saskatchewan before moving to Ottawa and working for seven years at the Dependents Allowance Board. ${ }^{34}$

The limited information available regarding the working conditions of this first generation of Carleton employees suggests that the environment could be challenging. Initially, the college had office space in the Ottawa High School of Commerce, which was housed in Glebe Collegiate. ${ }^{35}$ Wardle's memories of her third-floor office were of a sunlit classroom that was nonetheless "spartan and unwelcoming." ${ }^{36}$ Unlike clerical staff in other organizations who might be one of a team of more than 10 people seated in the same workspace, ${ }^{37}$ the few individuals employed at Carleton that first year had this room to themselves and clearly the environment made a lasting impression on Wardle. Even after fifty-six years, her description of this space was detailed, right down to the equipment on her desk. Perhaps less noisy than a "steno pool" with its many clacking typewriters, or the floor of a "pounding room" in a factory, ${ }^{38}$ there were still distinct physical disadvantages to the college office - although Wardle seems to have taken some consolation in sharing the hardships with the college president.

[There was] a long counter, about two feet from the door, stretched almost halfway down the length of the room, with cupboards beneath it. There were two desks facing away from the windows, a large one at the far end, a smaller one facing the door. Some filing cabinets stood against the wall to the right of the smaller desk. The desk chairs were arm-types, and upon each desk was a telephone, an "in" basket and an "out basket", and copies of the first Calendar.

\footnotetext{
${ }^{33}$ Queen's University, Queen's Encyclopedia, Admission of Women at Queen's, accessed January 15, 2014, http://www.queensu.ca/encyclopedia/w/womenatqueens.html,

${ }^{34}$ Schreiber, "Campus Close-up," FN 373, Chapter 2.

${ }^{35}$ Wardle, Reminiscences, 3.

36 Ibid.

${ }^{37}$ Hugh A. Dempsey, “Confessions of a Calgary Stenographer,” Alberta History 36, no. 2 (Spring 1988): 5.

${ }^{38}$ Bird, "Hamilton Working women in the Period of the Great Depression." They also compare favourably to those of women in previous generation such as those working at the Bell Telephone Company who went on strike in 1907. Sangster, "The 1907 Bell Telephone Strike."
} 
There were several side chairs. Fiscal restraint was evident, for although the furnishing (sic) were of good quality, they were obviously second-hand. ${ }^{39}$

Winter came, and the big office windows let in a lot of cold air. It became a daily battle to keep warm, despite the steam hissing in the radiators. I would sit with my snow boots [sic] on, my feet in the right-hand bottom drawer of my desk to keep them warm. Dr. Tory wore his new zipper-closing goloshes [sic], kept his gray homberg [sic] hat upon his head, and a woollen scarf around his neck. The radiators' complaints were often punctuated by his sneezing. He knew that he looked ridiculous, and with a sheepish grin on his face he would look down the room at me. We would burst into laughter. We soon learned to bring hot thermoses of tea with in the mornings. How I loved that Packard on the cold Ottawa mornings! ${ }^{40}$

Working days were apparently long in the first few years and erratic. President

Tory had warned Wardle that she would have to be a "willing" assistant, which translated into working days that were "full and taxing, with much administrative detail, and sometimes irregular hours. ${ }^{, 41}$ The latter proved to be no exaggeration and although Wardle began her first day on the job at 8:50 a.m., she soon found herself starting work at 8:30 a.m. during the week, attending staff meetings on Sunday afternoons and working half-days with Tory during the Christmas and Easter holidays. Betty Buckley had a similar experience in her first years at the college when she had a more junior position in the registrar's office. ${ }^{42}$ When looking back in 1977 at her 31-year career with the university, she recalled long hours spent "burning ... [the] midnight oil" to schedule classes as well as "Saturday mornings and weekday" nights along with other office staff, in part because the college offered evening classes for part-time working students. ${ }^{43}$

As most classes were still offered at night, the girls in the office took turns being on duty - handed out roll books to instructors, phoning students if classes

\footnotetext{
${ }^{39}$ Wardle, Reminiscences, 3.

${ }^{40}$ Ibid., 9

${ }^{41}$ Ibid., 2.

${ }^{42}$ Betty Buckley, Some Remembrances. Given at Spring Conference, May 1995, 1, Don McEown fonds, ACC-No. 2000-05, A278, History Betty Buckley, Carleton University Library Archives.

43 "The Years Roll By," This Week at Carleton 16, no. 16 (Thursday, September 15, 1977), FN 3, Chapter 2.
} 
cancelled and so on. Got to know a lot of interesting people on those evenings. Since there were Saturday classes, we tooks [sic] turns there as well, and we were also expected to distribute the mail. We were not sorry when Friday evening and Saturday classes finally dwindled. ${ }^{44}$

Presumably, once the college moved to the new First Avenue building in 1946, the physical space improved somewhat, and certainly by the early 1950 s, library staff finally had a working space that Carleton's librarian Hilda Gifford designed according to modern principles of librarianship. However, the popular basement canteen was not "impressive" $" 45$ and "crowded at all hours with students and staff",46 while library employees undoubtedly would have worked shifts when the library was open in evenings and on weekends. It is also unclear whether office employees had regular breaks or lunch hours, although Wardle and President Tory did stop for "cookies and cocoa" when they worked in his home library during holidays. ${ }^{47}$ Clerical workers at other organizations faced comparable working conditions as they spent long days under close supervision, taking dictation, typing, never having a "coffee break" and generally "just ran ragged" for nine hours a day and without the compensation of annual holidays, at least in the first few years of a new job. ${ }^{48}$ Plus, at work they could face other difficulties, such as being arbitrarily reassigned to jobs they had not been hired to do or sexual harassment from supervisors and fellow employees. ${ }^{49}$ These conditions may not have been as physically as arduous as those for industrial workers or the Bell girls who went on strike in 1907, but

\footnotetext{
${ }^{44}$ Buckley, Some Remembrances, 2.

${ }^{45}$ Neatby and McEown, Creating Carleton, 47.

${ }^{46}$ Buckley, Some Remembrances, 5.

${ }^{47}$ Wardle, Reminiscences, 8.

48 Bird, "Hamilton Women," 132.

${ }^{49}$ Bird, "Hamilton Women," 132; Dempsey, "Confessions of a Calgary Stenographer."
} 
office staff often worked in environments that were also highly regulated, entailed physical risks and had the potential to be exploitative. ${ }^{50}$

While the experiences of Wardle and Buckley may not be representative of all Carleton office staff in the early years, their employment does accurately reflect a significant trend at the college: unlike the faculty group where the majority of employees were men, women did the clerical work, with the exception of the odd office boy. ${ }^{51}$ This phenomenon is consistent with the hiring practices at other organizations during the period, when a "white-blouse revolution" had occurred during the late $19^{\text {th }}$ and early $20^{\text {th }}$ centuries, the feminization of paid clerical work in Canada and other "advanced economies" such as those of the United States and the United Kingdom. ${ }^{52}$ In his histories of the feminization of clerical work in Canada, Graham Lowe has explained that typically $19^{\text {th }}$ century clerks were men working in commercial enterprises such as banks and insurance companies who were responsible for accounting-related and other administrative tasks. ${ }^{53}$ Coming for the most from middle class families ${ }^{54}$ and having acquired "craft-like" skills through a long period of training, ${ }^{55}$ they went to work in "white-collars" and commanded wages that were high relative to men doing manual and

${ }^{50}$ Sangster, "The 1907 Bell Telephone Strike."

${ }^{51}$ OAAL, Minutes of the $47^{\text {th }}$ Meeting of the BOG, April 7, 1949, 2, FN 1, Chapter 1.

${ }^{52}$ See Chapter 1 of this thesis for discussion of the definition of feminization. Gregory Anderson, ed. The White-Blouse Revolution. Female Office Workers since 1870 (Manchester and New York: Manchester University Press, 1988). For further discussion of the feminization of clerical in the United Kingdom, see Samuel Ross Cohn, "Clerical Labor Intensity and the Feminization of Clerical Labor in Great Britain, 1857-1937," and Fiona McNally, Women for Hire. A Study of the Female Office Worker (London and Basingstoke: MacMillan Press, 1979). For the history of the feminization of clerical work in Canada, see Lowe, Women in the Administrative Revolution and for the history of clerical work in North America, see Kim England and Kate Boyer, "Women's Work: The Feminization and Shifting Meanings of Clerical Work."

${ }^{53}$ Lowe, Women in the Administrative Revolution, 1.

${ }^{54}$ Graham S. Lowe, "Class, Job and Gender in the Canadian Office," in Canadian Working Class History, $2^{\text {nd }}$ edition, ed. Laurel Sefton MacDowell and Ian Radforth (Toronto: Canadian Scholars' Press Inc., 2000), 386.

${ }^{55}$ Ibid., 383. 
unskilled labour; they also expected to have a career, or to go into business for themselves. ${ }^{56}$ Between 1900 and 1930, however, the Canadian economy changed radically and in the process experienced an "administrative revolution." According to Lowe, three factors fueled a dramatic transformation in the structure of Canadian industries, organizations and occupations: the "ascendancy of corporate capitalism"; the commensurate development of large private and public manufacturing and service corporations (e.g., federal government departments) that were inherently bureaucratic in nature; and the emergence within these organizations of administrators intent on using modern management methods and technology to run efficient, rational operations and handle the sizeable mounds of paperwork generated by daily operations. ${ }^{57}$

The growth of these "centralized bureaucracies" in turn led to a fundamental shift in the nature of office work. ${ }^{58}$ Clerks were no longer skilled generalists. Instead, clerical employees could now be assigned a myriad of specialized administrative jobs that were presumed to require less skill and find themselves responsible for shipping, proofreading, accounting, mail sorting and delivery as well as other basic clerical tasks such as filing. ${ }^{59}$ Stenography and typing were included in clerical duties but Lowe argues that these skills were not feminized—-"almost from their inception they were defined as women's work. ${ }^{60}$ As corporations grew in number, size and complexity, the demand for clerical workers went up as did the higher labour costs that came with this larger administrative workforce. Women were attracted to this work in significant numbers and their

\footnotetext{
${ }^{56}$ Ibid.,; 383-84.

${ }^{57}$ Lowe, Women in the Administrative Revolution, 25.

${ }^{58}$ Ibid., 49. Using data from the Dominion Bureau of Statistics, Lowe shows that between 1901 and 1931, the percentage of clerical workers in Canada doubled from 3.2\% to 6.7\%. From 1921 to 1971, this percentage grew to $15 \%$.

${ }^{59}$ Ibid., 48.

${ }^{60}$ Ibid., 74 .
} 
participation rate in the clerical workforce rose from $5.3 \%$ in 1901 to $17.7 \%$ in $1931 .^{61}$

These numbers seem remarkable, given that this work could be typecast as monotonous, dead-end and unskilled. ${ }^{62}$ However, many clerical workers considered these jobs to be better than alternative positions in other economic sectors. Female clerks received wages that were higher than those paid for other forms of work open to them ${ }^{63}$ - and than those earned by many Canadian male workers ${ }^{64}$ _ even though employers paid them annual earnings that were persistently low relative to those earned by male clerical staff. ${ }^{65}$ For example, in 1901 the average annual earnings for a male clerical worker were $\$ 496.49$ while those for his female counterpart were $\$ 264.37$ or $53 \%$ of his salary. ${ }^{66}$ By 1931 , the gap had narrowed somewhat and women were making $\$ 830.00$ per year, or $71 \%$ of that earned by men who made on average $\$ 1,153.00$ year. ${ }^{67}$ This wage discrimination was often rationalized in terms of the inherent political and physical "disabilities" of being female - the "curse of Eve" - that made them inferior to men and not only prevented them from masculinized work but made their own work less socially and economically valuable. ${ }^{68}$ Despite the disadvantages, however, women continued to do office work in greater and greater numbers over the course of the $20^{\text {th }}$ century. ${ }^{69}$

${ }^{61}$ Ostry, The Occupational Composition of the Canadian Labour Force, 50-51.

${ }^{62}$ Lowe, "Class, Job and Gender," 383 and 386.

${ }^{63}$ Kate Boyer, "“Neither forget nor remember your sex": Sexual Politics in the Early Twentiethcentury Canadian Office," Journal of Historical Geography 29, no. 2 (2004): 212. For general discussion of women's work in Canada during the early $20^{\text {th }}$ century see also Veronica Strong-Boag, "The Girl of the New Day: Canadian Working Women in the 1920s," Labour / Le Travail 4, (1979): 131-64.

${ }^{64}$ Altman and Lamontagne, "On the Natural Intelligence of Women," 1047.

${ }^{65}$ Lowe, Women in the Administrative Revolution, 49.

${ }^{66}$ Lowe, "Class, Job and Gender," 387.

${ }^{67}$ Ibid.

${ }^{68}$ Lowe, Women in the Administrative Revolution, 70. For a discussion of the "cult of domesticity," a concept used to explain the gendered nature of women's work, see Cynthia R. Comacchio, The Infinite Bonds of Family. Domesticity in Canada, 1850-1940 (Toronto, Buffalo, London: University of Toronto Press, 1999).

${ }^{69}$ Ostry, The Occupational Composition of the Canadian Labour Force. 
Early personnel practices at Carleton reveal a second critical trend in Canadian women's work during the early $20^{\text {th }}$ century, and one that eventually led to conflict amongst the university's support staff during unionization: the entry of significantly greater numbers of married women into the paid labour force. In their meeting minutes, the governors would faithfully record detailed information about the instructional, clerical, maintenance and canteen employees who walked into or out of the college (and then the university). The disclosure of employee information that is now considered confidential typically included the marital status of the female workers. While men were referred to as "Mr. William Dempster" (a marriage-neutral courtesy title), the women were identified as "Mrs. Lillian Heather,"71 "Mrs. Laverna McDowell,,"72 "Miss Dorothy Clark",73 and, even in 1968, "Mrs. M. Armour.",74 The presence of a sizeable number of single female workers was not necessarily remarkable by the 1940s, but the higher number of married women was. According to the 1911 national census, only $16.6 \%$ of Canadian women were "gainfully employed," i.e., those over fourteen years of age who were working for pay or contributing to production. ${ }^{75}$ This recorded rate grew to $19.9 \%$ in 1921 and by 1941 it had risen to $20.4 \% .{ }^{76}$ However, while $58 \%$ of Canadian women were married in that third year of World War $\mathrm{II},{ }^{77}$ only $4.5 \%$ of married women did paid work outside the home.

\footnotetext{
${ }^{70}$ OAAL, Minutes of the $25^{\text {th }}$ Meeting of the BOG, September 3, 1946, 3, FN 1, Chapter 1.

${ }^{71}$ OAAL, Minutes of the $19^{\text {th }}$ Meeting of the BOG, December 20, 1945, 2, FN 1, Chapter 1.

${ }^{72}$ Ibid.

${ }^{73}$ OAAL, Minutes of the $58^{\text {th }}$ Meeting of the BOG, December 20, 1945, 2, FN 1, Chapter 1.

${ }_{75}^{74} \mathrm{CU}$, Minutes of the $194^{\text {th }}$ Meeting of the BOG, January 17, 1968, 11, FN 1, Chapter 1.

${ }^{75}$ Frank T. Denton and Sylvia Ostry, Historical Estimates of the Canadian Labour Force (Ottawa: Dominion Bureau of Statistics, 1967), 29 and 1.

${ }^{76}$ Ibid., 28-29.

${ }^{77}$ Prentice, et. al., Canadian Women. A History, 412.
} 
Just as the feminization of women's work has been attributed to prevalent cultural ideologies that created a sexual division of labour in the paid workforce, so too has the historic lack of married women working for pay. In $19^{\text {th }}$ and early $20^{\text {th }}$ century Canada, men were socially identified as the sole paid breadwinner and women as the unpaid worker responsible for a range of manual, nurturing-related tasks in the home. These responsibilities could include child bearing and rearing, cooking, cleaning, sewing and gardening and were assumed to be quintessentially feminine and suited to the nature and physical as well as intellectual and psychological capabilities of women. ${ }^{78}$ Such cultural ideals were actively and effectively invoked to discourage married women from competing with men for the "family wage" by working outside the home and thus single, widowed and divorced women were substantially responsible for the increasing rates of female participation in the labour force during the early years of the $20^{\text {th }}$ century. ${ }^{79}$ However, within ten years these statistics were substantively different. In 1951, 11.2\% of married Canadian women were participating in the paid labour force and by 1971 that percentage had tripled. ${ }^{80}$

The increased presence of married women in the paid labour force should not be construed as a definitive sign that Canadian social mores had been profoundly altered. The official Dominion Bureau of Statistics data collected for the national censuses had not necessarily captured all of the work done by women in general, let alone married women specifically, and certainly women's experiences had historically varied according

\footnotetext{
${ }^{78}$ See for example, Armstrong and Armstrong, The Double Ghetto, 53-58; Leo Johnson, "The Political Economy of Ontario Women in the Nineteenth Century," in Women at Work, 1850-1930, (Toronto: Canadian Women's Educational Press, 1974); and Prentice et. al., Canadian Women, 75-84.

${ }^{79}$ Armstrong and Armstrong, The Double Ghetto, 152. See also Strong-Boag, "The Girl of the New Day: Canadian Working Women in the 1920s."

${ }^{80}$ Armstrong and Armstrong, The Double Ghetto, 17.
} 
to socioeconomic status and ethnicity. As Joan Sangster argues in her history of working mothers in Canada in the period from 1945 to 1970, historically wives in working class families had consistently needed to boost the family income in a variety of ways that were not always officially recognized and reported as paid employment. ${ }^{81}$ In addition, Canadian society was torn on the issue of women employed outside the home. Sangster found that even as more married women went back work after their children were older and less dependent, there was an on-going debate in the Canadian media as to the appropriateness of gainful employment if it meant that wives and mothers left their husbands and children at home. ${ }^{82}$ Old domestic stereotypes die hard and certainly in the 1950s and early 1960s "June Cleaver remained the dominant popular image of motherhood"; working mothers had to justify their employment as financially necessary to avoid being labelled as selfish or unnatural. ${ }^{83}$ Even in the late 1960 s and early 1970 s when these ideas and norms were being contested during the latest wave of feminismand very publicly in national women's magazines such as Chatelaine - not everyone was forsaking the ideal of the male breadwinner. ${ }^{84}$ Certainly some married women may still have seen themselves (or were perceived by others) as working only for "pin money,"85 i.e., relatively small salaries that would earn them the income they wanted for discretionary expenditures such as redecorating their living room or a new pair of shoes.

\footnotetext{
${ }^{81}$ Joan Sangster, "Doing Two Jobs: The Wage-Earning Mother, 1945-1970," in Joy Parr, ed., $A$ Diversity of Women: Ontario, 1945-1980 (Toronto, Buffalo, London: University of Toronto Press, 1995), 100.

82 Ibid., 98.

${ }^{83}$ Ibid., 102. See for example, Crean, Grace Hartman, 39. Grace Hartman, the first female president of CUPE, is an interesting example of the working wife and mother during this period. In this bibliography of Hartman, Crean explains that Hartman had worked prior to marriage and went back to work in 1954 because her husband Joe's employment as a construction worker was seasonal. She made this decision despite the fact that "in the fifties this was an admission of failure." In fact, one of Hartman's sisters was firmly of the opinion that a wife should be at home, looking after the household and children.

84 Joch Robinson, "The Media and Social Change," 96.

85 Janice Taflet, “Gendered Dollars: Pin Money, Mad Money, and Changing Notions of a Woman's Proper Place," Essays in Economic \& Business History 26, (2008): 189-202.
} 
They were not working for the "family wage," although if they made such claims publicly, they may have been hiding real economic need that was not expressed in case it reflected poorly on husbands as providers. ${ }^{86}$

Through their hiring practices, college decision makers constructed a gendered occupational hierarchy in the period between 1942 and 1958 that segregated most female employees into lower paying clerical, maintenance or canteen work. Official statistics for the entire Carleton College workforce are not readily available for these early years. However, again official Board minutes reveal that Carleton governors and senior administrators consistently organized staff into five distinctly ranked categories that reflected the institutionally-biased seniority of each group: instructional, administrative, clerical, maintenance and "canteen." Typically, the minutes recorded new hires, promotions or transfers and resignations for the five categories in this order and, within each group, individuals would be identified by name, marital status (if female); job title (often including some indication of whether the job was senior or junior); department and pay; both amount and frequency of remuneration (i.e., annual, monthly or weekly). As previously mentioned, the academic credentials of teaching staff would be noted but information regarding the educational background of all other staff was omitted and pay scales varied for each group. Remuneration levels could overlap slightly (e.g., the senior clerical staff could overlap with that of a junior teacher) but typically instructors and senior administrators were in the highest earnings bracket, followed by the clerical staff and senior maintenance workers (e.g., the caretaker) and then the junior maintenance staff and canteen employees. Compensation also varied in terms of the frequency of

\footnotetext{
${ }^{86}$ Sangster, "Doing Two Jobs," 102; See also Taflet, “Gendered Dollars,” 192.
} 
payment: teachers were paid on an annual basis, clerical and maintenance staff received monthly salaries while canteen staff earned weekly wages.

As Graphs 4.1, 4.2, 4.3 and 4.4 demonstrate, between the 1940s and the late 1960s the board segregated men and women into occupational silos. The majority of instructor, technical and maintenance staff were men while those in the library or doing administrative work were women.

\section{Graph 4.1 Carleton University Board of Governors Approved New Hires of Academic Staff (1942-1967) ${ }^{87}$}

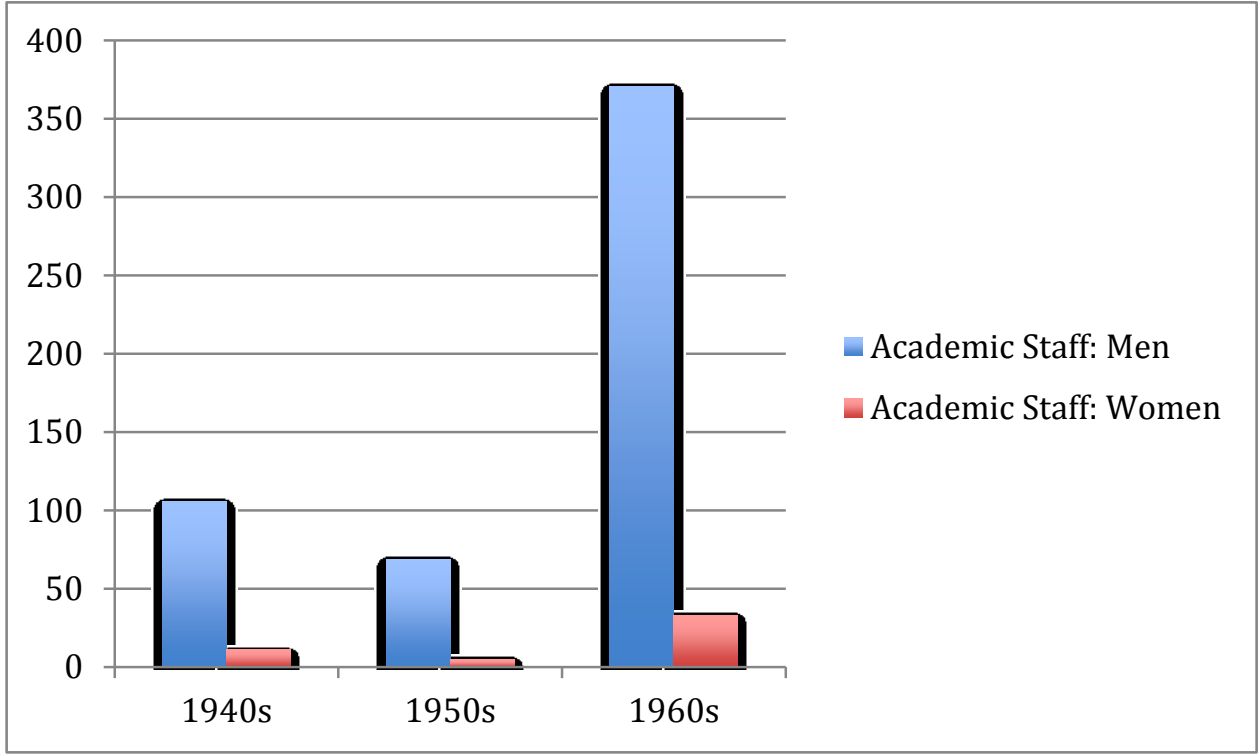

${ }^{87}$ These graphs are based on a simple count that I did of all the board-approved hires that appeared in the official board minutes between 1942 and 1968 when the hires of support staff were no longer recorded in the main section of the minutes. I have not distinguished between positions that seemed to be managerial and those that did not. I was simply interested in seeing if the recorded decisions were consistent with the occupational segregation experienced by Carleton employees. In addition, official university personnel statistics with a breakdown of employees by job and sex is not available for these years. 
Graph 4.2 Carleton University Board Approved New Hires of Library Staff, Including Librarians and Non-Librarians (1942-1967)

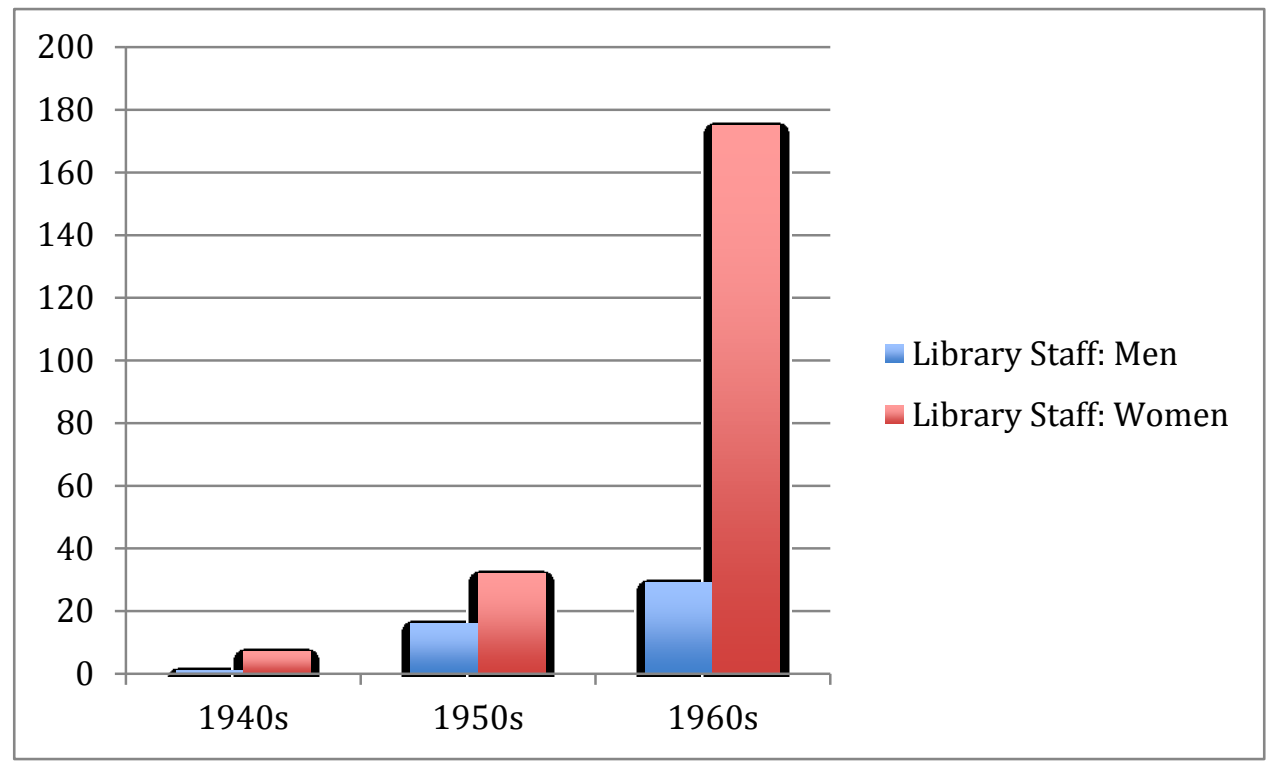

Graph 4.3 Carleton University Board of Governors Approved New Hires of Administrative and Clerical Staff (1942-1967)

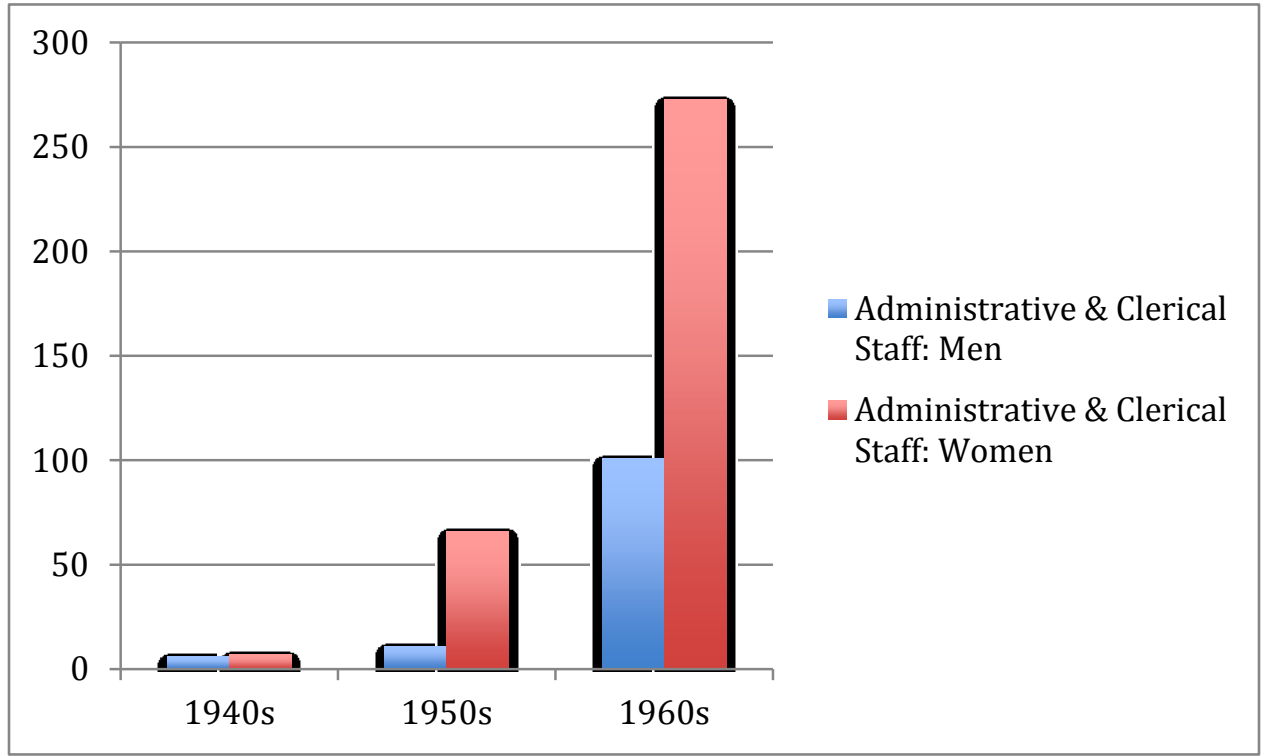




\section{Graph 4.4 Carleton University Board of Governors Approved New Hires of Technical Staff (1942-1967)}

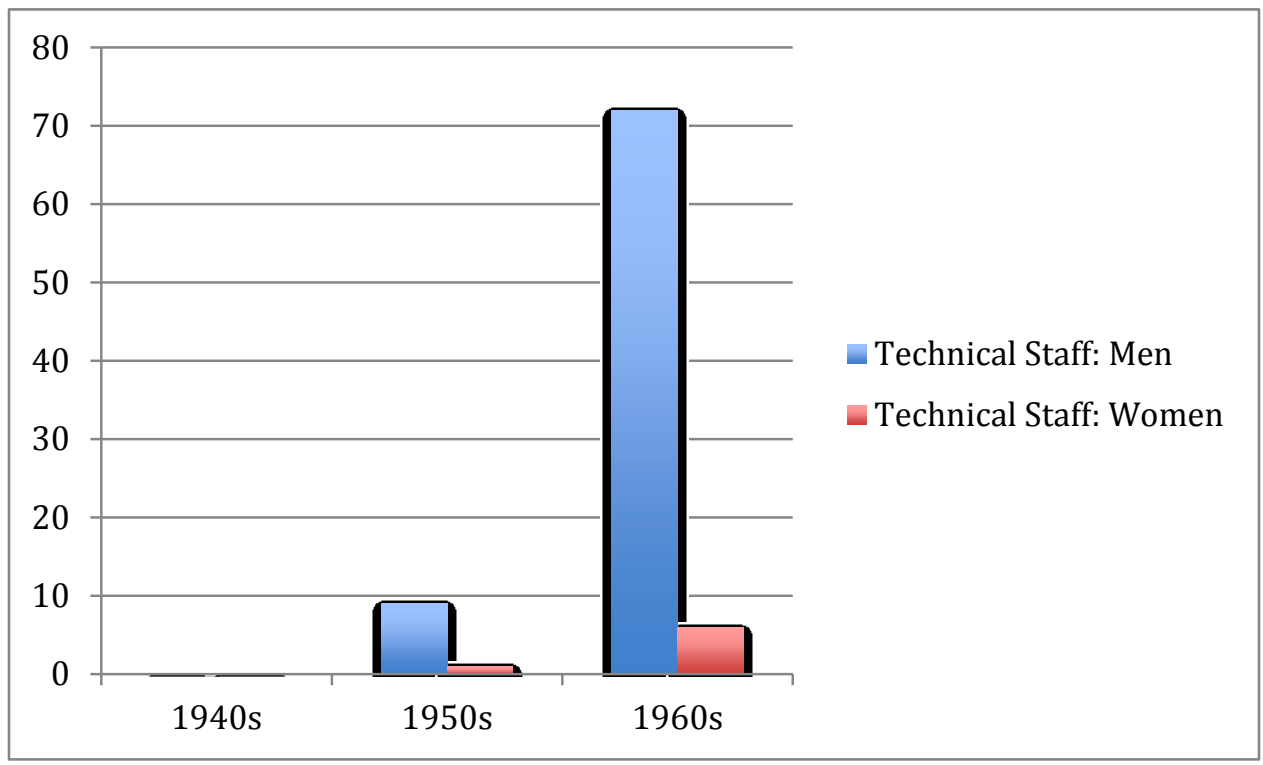

While Board members used the same ranking system for faculty positions as that in place at other Canadian universities, they do not appear to have had any formal process of job classification for other employee positions that would explain this hierarchy—this decision would come in the 1960s. However, personnel decisions for all groups generally seemed to have been consistent with culturally dominant ideas about various forms of work and the "sexual division of labour" that justified the lack of equivalency between jobs and thus the difference in status between employee groups. As former CUASA president, Jill Vickers, wrote thirty-five years later,

In our society ... it has often been assumed that tasks which involve working with one's head are both more essential and more difficult than those which involve working with one's hands. In addition, it has generally been assumed that tasks related to production are more important than those related to reproduction and maintenance. ${ }^{88}$

\footnotetext{
${ }^{88}$ Vickers and Adam, but can you type?, 9.
} 
These ideas seem to validate the creation of an occupational pyramid that placed the white-collar non-manual instructional staff at the top and the cleaners doing manual work at the bottom, particularly as Tory—as well as successive presidents and board members - was hiring academic staff with the advanced educational credentials increasingly demanded in Canada for university teaching. These employees would naturally outrank those blue-collar workers doing the seemingly less skilled manual labour on campus who might not even need a high school diploma to be hired, such as the caretaker. Between and within categories, it could also seem logical that certain jobs were masculine and others feminine. ${ }^{89}$ Teaching is more intellectual and productive than typing and thus better suited to men; likewise tending to buildings is more demanding than cleaning floors or toilets. But where the arbitrariness of these distinctions becomes more obvious, the boundaries could be blurred. For example, when the skills of some "white blouse" female jobs might seem equivalent to those of certain "blue shirts" positions, then the relative status of these forms of work might overlap, as evidenced by salary scales where the top manual labour (e.g., the caretaker) could be rewarded with the same compensation as the top non-manual female labour (e.g., a bookkeeper).

Support staff might have accepted the relative status of each employee group as logical or reasonable but tangible proof of their thoughts and feelings from this period is rare. However, the experiences of individuals such as Dorothy Wardle, Betty Buckley and Evelyn Aldridge, along with those of employees working at comparable jobs in other organizations during approximately the same period, suggest that clerical staff could have opinions compatible with those of Bette Smith: however routine some aspects of their work might be, their jobs still offered challenges and required levels of knowledge,

\footnotetext{
${ }^{89}$ See Chapter 1 of this thesis (Historiography)" for discussion of the feminization of work.
} 
decision-making and responsibility not reflected in the low rates of pay they received. In addition, although they did not take formal labour action, such as forming or joining a union, they nonetheless recognized and found ways to protest the undervaluing of their work. Wardle, Buckley and Aldridge seem to have felt confidence and pride in their ability to perform relatively demanding jobs during the 1930s and 40s. Wardle did not wait for a job advertisement to apply to the new college. After finishing her undergraduate degree, which included holding a "high profile position" in student government, she telephoned Dr. Tory "offering my services." ${ }^{, 00}$ Apparently her position was "everything he said it would be, and more" and she worked for him for two years, contributing to the creation of the new college. She enjoyed the "laughter" as well as the hard work and had contact with people at every organizational level while fulfilling her "important" administrative responsibilities. ${ }^{91}$ Similarly, Buckley saw Carleton as a "second home" where she participated in "happy occasions" such as commencement and was able to work directly with "a great many" students, helping them with the admissions process. More importantly, she progressed up the organizational ladder doing a series of jobs that took her from the two classrooms in the original college to the university on the Rideau River where she had "a great many opportunities" and eventually became the assistant secretary to the Board of Governors.

Aldridge was not hired at Carleton until the end of the 1950s but by then she had already spent a number of years working in Ottawa. As a young woman in the 1930s, she found work despite the severe economic depression but, like many women and men in the national capital, initially not where she hoped to get a job: the federal government.

\footnotetext{
${ }^{90}$ Wardle, Reminiscences, 2.

91 Ibid.
} 
I can remember begging for work, 25 cents an hour at Kresge's ... then I answered an ad for People's Credit Jewellers. In the meantime, I'd taken a government test that was typing [and] all the other things. And I didn't work very long for People's Credit Jewellers when I got a call. And I went to work in the Civil Service Commission in the Hunter building. And I can remember, I'd look in the window as I passed there and I'd think, "Oh, it would be so nice to work there. ${ }^{92}$

Over time she gained "permanent" status and, like Buckley, took advantage of the opportunity to work in an organization that was large enough to allow her to compete for new positions in a variety of departments or agencies. ${ }^{93}$ Women doing clerical jobs in other parts of Ontario and Canada also described employment experiences that were positive and stimulating. A stenographer working at the Eaton's department store in Hamilton, Ontario during the 1930s "just loved the typewriter" 94 and did not seem to view her job as a simple routine. ${ }^{95}$ In fact, other stenographers saw the process of "producing correspondence" as collaborative, where they participated by using their language knowledge and skills to correct the grammatical or spelling mistakes made by the employer during dictation. ${ }^{96}$ In addition, under certain circumstances they would answer letters themselves, rather than simply waiting to record and type the response of their boss. ${ }^{97}$ As an anonymous stenographer from the first generation of clerical workers wrote in the mid-1910s, "no St. Bernard dog on a Swiss mountain top was ever more faithful to its monkish owner than this little band of girls to the firm in which it plays a small, but important, part." 98

\footnotetext{
92 Aldridge, oral history. Kresge's was a branch of the American department store chain of the same name.

93 Ibid.

94 Bird, "Hamilton Working Women," 133.

${ }^{95}$ Dewalt, "Men, Women and Machines," 19.

${ }^{96}$ Ibid.

${ }^{97}$ Ibid., 28-29.

${ }^{98}$ Dempsey, "Confessions of a Calgary Stenographer."
} 
Whatever satisfaction they derived from their work, however, office employees were also aware that their skills and expertise were underrated if not treated as invisible by senior organizational decision-makers. Wardle had been working for Dr. Tory for two years when, in early 1944, she decided to leave the college and find a job at another institution.

[At Carleton] there was the possibility of becoming buried in my kind of administrative work, important as it was, and eventually being almost overwhelmed by responsibility, with no possibility of assistance. I was not prepared to grind on. I was young and yet to experience the wider world. There was also the matter of salary. Despite the efforts of Dr. Tory and W.M. Connor, the Board had not moved on raising it. There had been no compensation for all the hours of extra evening work at Dr. Tory's home. I was tired and frustrated, and on March 1 tendered my resignation. ${ }^{99}$

Even if Wardle considered her position less clerical and routine than other available forms of office work, she nonetheless recognized that her time and skills were valuable and deserved to be compensated accordingly. At no point does she seem to have considered unionization as a strategy for improving her pay but she did take the one form of job action readily available: she left Carleton and found work elsewhere. And Dr. Tory supported her decision. Despite his disappointment in losing a good employee, he recognized that "we can't expect to keep good people in Administration, unless they [the Board] are willing to pay decent salaries."

Aldridge also considered resigning when she faced another, and common, form of gender inequality as a federal government worker. Having become a permanent employee, she lost this status when she got married and "nothing worked very well" without that job security. Now she was forced to move from job to job, not as a result of her desire for different or better work but because of her temporary status, and this precariousness took

\footnotetext{
${ }^{99}$ Wardle, Reminiscences, 13.

${ }^{100}$ Ibid.
} 
its toll. After working at the Governor General's office where she was assigned on a short-term basis, she almost left the civil service. However, her individual skills and abilities kept leading to other opportunities and it was not until she became pregnant that she made the decision to stop working.

I went back to Civil Service Commission but I decided when I wasn't being reclassified to the same level that these people ... "I'm quitting." So, I think there was an ad for the solicitor to the Director of [the] Veteran's Land Act. And he was to come into Ottawa once a week into the offices in the Supreme Court building. Top level, beautiful view. Oh, I had a nice office ... I hadn't been there all that long when ... the office was about to close. And then I got a call from the Department of Justice, the Minister of Justice, Stewart Garson, so I went for an interview with his secretary, and I was hired. And that's 1949. But ... I was only there a couple of months when I was pregnant. And, mind you, they asked me if I would go to Winnipeg with them ... during the election campaign. Well I couldn't very well go. So I quit. ${ }^{101}$

Like Wardle, Aldridge considered an individual (rather than collective) form of job action to protest working conditions she considered to be unfair. However, her experience reflects the employment-related chronic inequities faced by clerical staff that were (and are) unrelated to their skills and abilities and could lead to either poor pay or lack of job security or both.

Aldridge might have made the decision to change jobs regardless of where she was living and working at that time - and indeed, she might have had a similar experience anywhere in Canada. However, it is unsurprising that she would have this particular experience in Ottawa, given that the nation's capital was a highly gendered workspace in the early to mid- $20^{\text {th }}$ century. Although a "male bastion" in the $19^{\text {th }}$ century, ${ }^{102}$ both men and women began to be hired into the federal public service between 1900 and the 1930s and size of the government workforce multiplied rapidly,

\footnotetext{
${ }^{101}$ E. Aldridge, oral history.

${ }^{102}$ Taylor, Ottawa. An Illustrated History, 85.
} 
increasing from 1,129 in 1900 to 11,766 (8009 of which were permanent positions) in 1931. ${ }^{103}$ This made the federal government the largest employer in the city at the time. ${ }^{104}$ The proportion of women in the civil service remained at approximately $13 \%$ until after World War II and then grew steadily until the federal government was the largest employer of women in Canada in $1970 .{ }^{105}$ This lack of growth in the number of female employees prior to the late 1940s and early 1950s was not due to lack of interest. As Aldridge had noticed, the offices seemed to be nice places to work and regularly women "flooded in" to take the civil service entrance exams. ${ }^{106}$ However, the hiring practices of the Civil Service Commission were imbued with the traditional ideas related to women's work, and particularly the work of married women. In her 1970 report Sex and the Public Service in Canada, author Kathleen Archibald noted that from the late $19^{\text {th }}$ century until the mid-1950s, the official hiring policy was to "keep the numbers of women down." In particular, from 1921 to 1955 commission personnel officers would only hired married women on a temporary basis or if they need to be "self-supporting." ${ }^{107}$ As Aldridge discovered, any woman who married was required to resign and could only be hired back on a temporary basis. Moreover, those women who were hired were segregated into the lowest paying jobs in the service. ${ }^{108}$ This policy set the standard for the rest of the country; as Archibald pointed out, "the government is more than an employer; it is also responsible for the welfare and progress of the nation as a whole." ${ }^{, 109}$ Although these provisions were rescinded in 1955, Canadian historian Patrizia Gentile has suggested that

\footnotetext{
${ }^{103}$ Ibid., 212.

${ }^{104}$ Ibid., 213.

${ }^{105}$ Archibald, Sex and the Public Service, 15 and 9.

${ }^{106}$ Ibid., 16

${ }^{107}$ Ibid.

${ }^{108}$ Lowe, Women in the Administrative Revolution, 71.

${ }^{109}$ Archibald, Sex and the Public Service, 9.
} 
the civil service culture was still uncomfortable with the idea of working women and effectively found ways to continue reinforcing traditional gender stereotypes, such as the "Miss Civil Service" and "Mr. Government Man" beauty pageants that were held from 1951 to $1973 .{ }^{110}$

The end of the 1950s marked the beginning of a new period of expansion for the Carleton community that proved to be exciting and beneficial for clerical employees. Faculty, staff and campus moved into the new Rideau River campus, which initially housed only two buildings - the MacOdrum Library and the Tory Building — and conditions could be cramped. ${ }^{111}$ Under the leadership of the energetic and popular President Dunton (1958 to 1972), however, academic and non-academic operations within the university expanded exponentially, and support staff could be offered new opportunities for recognition and on-the-job advancement at the university. Notwithstanding this positive air of change, Dunton also oversaw the further entrenchment of the gendered occupational hierarchy. Hiring practices did not change substantially as more women worked in offices that grew in size, number and responsibility. In addition, university administrators introduced a job evaluation program that amalgamated three groups of employees—clerical, administrative and technical— and solidified further the boundaries between male and female work. Dissatisfaction with working conditions began to emerge in the mid- and late 1960s and the job assessment process proved to have an unintended consequence: it created a large group of employees

${ }^{110}$ Patrizia Gentile, "Government Girls" and "Ottawa Men”: Cold War Management of Gender Relations in the Civil Service, in Gary Kinsman, Dieter K. Buse and Mercedes Steedman, eds., Whose National Security? Canadian State Surveillance and the Creation of Enemies, (Toronto: Between the Lines, 2000): 130-41.

${ }^{111}$ P. Finn, oral history. 
who, however uneasily aligned and occupationally fragmented, eventually became the basis for the support staff union at Carleton in the 1970s.

The excitement and satisfaction of working at Carleton during Dunton's presidency was infectious. Margaret McEown who had been hired in the early 1960s describes these years as "happy times ... buckets of fun."112 Although she considered herself to be part of the management team, McEown relished her working life at this time, perhaps for reasons that were similar to those of other non-academic office staff. Employment at the university offered opportunities to take on interesting, varied and more senior jobs without the pre-requisite of specialized training and according to McEown, who became responsible for hiring support staff between 1966 and 1976, people "were ready for new experiences." ${ }^{\text {113 }}$ For women in particular, who traditionally had had limited access to post-secondary education in Canada, this could be an advantageous environment. A few might be working for discretionary income but McEown observed that employees were motivated by a variety of needs and goals.

Many of the women, who weren't married ... came to work at the university because of the flexibility ... The people who worked in the academic departments just about had the summer off ... There were those that went back for their kids, for free education ... [and] those that were career people ... and there were the young girls who worked there because they thought that they might find love. ${ }^{114}$

McEown's own experience was less atypical than it might have been a generation earlier. While her widowed mother had given McEown and her brother a reasonably comfortable upbringing "in a very nice neighbourhood" near Ottawa's Civic Hospital without entering the paid workforce, McEown had to work to support her own young children after her

\footnotetext{
${ }^{112}$ M. McEown, oral history.

${ }^{113}$ Ibid.

${ }^{114}$ M. McEown, oral history with D. McEown.
} 
divorce in the mid-1960s. ${ }^{115}$ She had no post-secondary training but she easily found fulltime work, first at the Canadian Good Roads Association ${ }^{116}$ and then at the university where she applied "for the benefits"-Carleton offered a pension plan. ${ }^{117}$ In her first position, she was the secretary in the science faculty but very quickly the head of personnel, Ruth Deacon, and Fred Turner, the bursar, handpicked her to be responsible for the hiring of secretarial and clerical staff. ${ }^{118}$ She "didn't go in with any skills. It just somewhat evolved" but this was still a period in which employees could learn on the job and "subsequently ... I took courses in counselling and interviewing."119

Such opportunities for advancement were sources of satisfaction not just because the jobs could be more interesting but also because they represented institutional respect for the abilities and efforts of individual employees; their contributions were "appreciated and recognized and rewarded." ${ }^{120}$ Like McEown, Evelyn Aldridge found herself being offered positions by senior administrators from different departments. She was hired on October 29, 1959 to work in the "information department" but made a positive enough impression that when her supervisor died suddenly, Dunton personally requested her to "to take over for now, until they could get someone." ${ }^{, 21}$ Although she had little experience, she found it "interesting" to deal with the press as well as promote special

${ }^{115}$ Ibid.

${ }^{116}$ David W. Monaghan, "Canadian Good Roads Association," Oxford Companion to Canadian History [online edition]. According to Monaghan, CGRA was an advocacy group that acted as "a clearinghouse for information relating to highway legislation as well as to encourage improved road construction and maintenance techniques throughout Canada," accessed October 1, 2013, http://www.oxfordreference.com.proxy.library.carleton.ca/view/10.1093/acref/9780195415599.001.0001/a cref-9780195415599-e-268.

${ }^{117} \mathrm{M}$. McEown, oral history.

${ }^{118}$ Ibid.

${ }^{119}$ Ibid.

${ }^{120}$ Ibid.

${ }^{121}$ E. Aldridge, oral history. 
lectures and collaborate with printing firms on the design of university publications. ${ }^{122}$

She subsequently moved to the library where Hilda Gifford, the chief librarian, had been waiting for her to apply. When she eventually grew tired of operating machines, converting funds and processing invoices, she did not have to fill in any job applications.

Dr. English was chairman of the economics department. And he came over ... into the library and he said, "Did I hear you're leaving?" I said, "Yes." He said, "How would you like to come work for us?" ... I went over and worked for them. I didn't have a clue. But ... I was there the rest of the time [I worked at Carleton]. ${ }^{123}$

During her tenure (which lasted twenty years), she worked with a number of departmental chairs and these faculty members valued her highly, according to Don McEown.

She ran the department and she had for a long time. The professors who were chairs [would say], "I don't want to do this stuff" so over to Evelyn Aldridge ... she was just an incredibly competent woman and ... and the faculty deferred to her ... they tended to look towards her in almost a mother ... this was a strong woman who was running the place. ${ }^{124}$

In fact, President Dunton intervened one more time in Aldridge's career at the university. When she considered applying for the position as his secretary, he indicated that he "felt that I was more valuable in the department" where she had wide responsibilities that included the supervision of more junior departmental staff. ${ }^{125}$

For this cohort, however, the meaningfulness of their role as Carleton support staff was not defined exclusively in terms of work-related activities or the development of a career. Non-academic staff formed the Carleton University Staff Association and this organization functioned as a social club for women that contributed to a strong sense of solidarity amongst its members. Margaret McEown was active in this group and has fond

\footnotetext{
122 Ibid.

123 Ibid.

${ }^{124} \mathrm{D}$. McEown, oral history.

125 Ibid.
} 
memories of the camaraderie that led to lifelong friendships. Just as faculty members might meet on Friday evenings for "happy hour," association members would get together at the Ottawa Hunt and Golf Club for "wonderful parties" but they would also collaborate on activities such as the production of a cookbook, and collected membership fees that could be used for a variety of purposes such as sending flowers to members who might be ill and in hospital. ${ }^{126}$ To some extent, such socializing was facilitated by the fact that the campus and workforce was still physically relatively small and centrally located. If faculty perceived the university to be a "community of scholars," non-academic staff could see it as "a little city," complete with services such as a post office and print shop, where people could easily meet one another. The positive nature of campus life at this time has also been attributed to the leadership of Dunton, who apparently paid close attention not just to members of the faculty or senior administrative staff but also to those in support positions. One of McEown's strongest recollections of being at Carleton is of two early meetings with the president, on campus and at a local ski hill.

The first week I was on campus, I went to the bank. This nice gentleman said, "Oh, how do you do ... you must be new here, I haven't seen you around." And I introduced myself. Then I went back and I said to Dolores Neilson, "This guy was talking to me." ... She said, "That's the president!" A couple of weeks later, I'm up at Camp Fortune, waiting in the ski tow line, "Well Marg! How nice to see you!" Now, I mean you know how different you look in ski clothes. And there he was with his toque pulled down ... And he recognized me, and he remembered my name. ${ }^{127}$

However pleasant and exhilarating it might have been to be on campus in these early years of the university, not every aspect of the work environment was positive. The physical space was not always ideal and hours could be irregular. Aldridge worked in an office with no windows at the library but although she had a "nice big office" in the

\footnotetext{
${ }^{126}$ P. Finn, oral history.

${ }^{127}$ M. McEown, oral history.
} 
economics department she also had a workload that led to long days. She could begin at "8 o'clock and I'd be there till 5:30 ... my day was so full. I very rarely would take a coffee break. There'd be so many interruptions. Students would come in and ... it just didn't seem to work [to take a break]. ${ }^{128}$ More senior personnel such as Margaret McEown might have found that there was enough flexibility in the day to play bridge at lunch time and not worry if the game ran over time but such freedom did not necessarily apply to all non-academic staff, particularly those in junior positions. ${ }^{129}$ Moreover, staff at Carleton were well aware that while some benefits were competitive with those offered by other Ottawa employers, their salaries continued to be low and specifically relative to those at the university's largest competitor, the federal government. ${ }^{130}$ In turn, senior administrators were sensitive to the growing discontent amongst support staff with salary levels and knew these concerns would need to be addressed.

In the mid-1960s the university's bursar Fred Turner made two significant decisions in response to "difficulties ... erupting in several areas." ${ }^{\text {131 }}$ He tasked Margaret McEown with introducing the Hay job evaluation system at Carleton; and he proposed that the Board of Governors approve salary increases for full-time technical (8\%), library $(10 \%)$, secretarial (6\%) and clerical (8\%) staff. ${ }^{132}$ In the short term, these increases would "alleviate the problem" of staff discontentment, which seemed to stem from the fact that Carleton salaries were as much as $20 \%$ lower than those being earned by workers in the Canadian civil service for comparable positions. Turner's long-term solution was the job evaluation program, which he hoped be implemented by July 1967. As McEown

\footnotetext{
${ }^{128}$ E. Aldridge, oral history.

${ }^{129}$ M. McEown, oral history.

${ }^{130}$ Ibid.

${ }^{131} \mathrm{CU}$, Minutes of the $179^{\text {th }}$ Meeting of the BOG, November 10, 1966, 3-4, FN 1, Chapter 1.

${ }^{132}$ Ibid.
} 
understood, the Hay system was chosen because "there were discrepancies. They figured they'd better get a platform so that they could assess ... jobs ... salary-wise." ${ }^{\prime 133}$ Prior to introducing this formal process, the approach to salaries had to some extent been perceived as more subjective and reliant upon the discretion of individual managers or faculty members. For example, when McEown's supervisor Ruth Deacon decided that he should get an increase in pay, Deacon simply spoke directly to her own boss, Fred Turner.

Well, Ruth went to him one time and said, "Margaret needs a raise. You know, she has to give cigarettes out to these people to make them relax ... So we have to increase her salary so she can hand out cigarettes." And I got a raise. ${ }^{134}$

And for clerical staff in the academic units, pay levels were whatever "the academic with the biggest and loudest voice could get for his staff.",135

As an alternative to this apparently unsystematic approach to determining remuneration for non-academic staff, a job evaluation system would formally and openly determine the organizational worth of individual positions. In her discussion of pay equity in Canada, Canadian social scientist Patricia McDermott suggests that since the 1940s such evaluations have generally consisted of two major processes: classification and valuation. ${ }^{136}$ Typically, the first step is to organize workplaces into broad job classes. ${ }^{137}$ These categories can include any number of positions that are grouped by similarity of function (i.e., duties and responsibilities determined by operational

${ }^{133}$ M. McEown, oral history.

${ }^{134}$ Ibid.

${ }^{135}$ Ibid.

${ }^{136}$ Patricia McDermott, "Pay Equity in Canada: Assessing the Commitment to Reducing the Wage Gap," in Judy Fudge and Patricia McDermott, eds., Just Wages. Feminist Assessment of Pay Equity (Toronto, Buffalo, London: University of Toronto Press, 1991): 21-32. Factors similar to those of the Hay system are still in use when classifying jobs belonging to the CUPE 2424 bargaining unit.

${ }^{137} \mathrm{McDermott}$ is describing the process as laid out in Canadian provincial pay equity legislation introduced between 1985 and 1989. 
requirements as well as traditional assumptions about job content) and qualifications. ${ }^{138}$

Jobs in a given class are then arranged hierarchically according to complexity, i.e., increasing levels of skill and responsibility, and this information is recorded in written job descriptions. The next stage is to quantify job complexity in order to determine compensation scales. Job descriptions are scored in terms of the weighted importance of a number of key factors related to job performance, weights that vary within and between job classes. The final point score represents the institutional value of each job and this numeric total is then equated to a given rate of pay. In unionized environments, pay scales are bargained but in non-unionized environments employers decide upon wages and their choices can be informed a number of considerations including information on the "going rates" in the local labour market. ${ }^{139}$

In the post-World War II period, the Hay system became one of the most popular “off-the-shelf" job evaluation programs in North America. ${ }^{140}$ Edward N. Hay was an American management consultant who began developing his approach to job appraisal in

${ }^{138}$ Ibid.

${ }^{139}$ Ibid., 26.

${ }^{140}$ Ronnie J. Steinberg, "Gendered Instructions: Cultural Lag and Gender Bias in the Hay System of Job Evaluation," Work and Occupations 19 (1992): 387-423. I was interested to discover if Canadian government departments and agencies use the Hay System, particularly as Carleton support staff compared their jobs and earnings to those in the federal civil service on a regular basis. I was unable to find any printed literature to indicate if this was the case. However, I e-mailed Rosemary Warskett, an adjunct professor in Carleton's Department of Law and Legal Studies. She researched the Public Service Alliance of Canada for her $\mathrm{PhD}$ has written on pay equity in the Canadian civil service. She put me in touch with Elizabeth Millar, who at one time held the position of Co-ordinator Classification and Equal pay Section, Membership Services Branch, Public Service Alliance of Canada. According to Millar, "the Hay System was only used for the Executive Group beginning approximately 1980. The public service job evaluation system dates from 1965-1967. It was needed in preparation for the Public Service Staff Relations Act which was passed in 1967 and which provided for collective bargaining for the first time in the federal government along with a grievance procedure including classification grievances. The sixty-nine different occupational groups primarily used quantitative classification systems, which mean each group has a set of factors, definitions, degrees and point ratings within each factor, and benchmarks to illustrate the interpretation of the factor. All group classification standards differed from the others. Even the level point boundaries were different so that 300 points in one group could indicate Level 2 and in another Level 6." Elizabeth Millar, e-mail message to the author, November 22, 2013. 
1943. ${ }^{141}$ His intention was to provide organizations with a method for comparing and equating senior managerial, professional and technical jobs in order to develop appropriate pay structures for this category of employee. ${ }^{142}$ As Hay Group partner Alvin O. Bellak explained in 1982, the group's program assessed job complexity in terms of three core factors: know how (all the skills needed for job performance); problem-solving (the thinking required to "identify, define and resolve problems" on the job); and accountability (the "answerability" and consequences of actions taken on the job). ${ }^{143}$ Working environment, i.e., the physical demands and hazards encountered on the job, could also be considered and measured but was not automatically incorporated into evaluations. The Hay consultants developed these metrics "in a real situation ... [with] a deep understanding of jobs and organizations." 144 While the program was originally envisioned as a strategy for assessing executive jobs and job categories were drawn from the manufacturing sector, by the 1970s it had become widely used for numerous positions at senior and junior organizational levels in the both the public and private sector. ${ }^{145}$

Fred Turner discussed the need for this formal job evaluation tool with the board but he was not explicit as to the reasons for specifically choosing the Hay program. Perhaps he (and Carleton's personnel administrators) thought that it would be most costeffective to use an existing system that was widely in use (and thus seemingly credible) rather than spending resources on the creation of a proprietary program for the university. In addition, he may have believed that the strength of the Hay approach was its ostensibly

\footnotetext{
${ }^{141}$ Alvin O. Bellak, "Specific Job Evaluation Systems: The Hay Guide Chart-Profile Method," in Handbook of Wage and Salary Administration, ed. Milton L. Rock (New York: McGraw-Hill, 1984): $15 / 1$.

${ }^{142}$ Bellak, "Specific Job Evaluation Systems." See also Steinberg, "Gendered Instructions."

143 Bellak, "Specific Job Evaluation Systems," 15/2-15/4.

144 Ibid.

145 Steinberg, "Gendered Instructions," 390.
} 
objective approach to quantifying the comparative value of jobs and, in turn, to setting pay scales. However, "pay forms the organic part of the relations between members of society" ${ }^{\prime 146}$ and the assumptions about the complexity and worth of various forms of work underlying the Hay method has an intrinsic bias that contributed to the establishment of wages that are not neutral because the process is "saturated" with historical ideas about the value of women's and men's work. ${ }^{147}$ Essentially, job evaluations are "social documents" that reflect the belief that intrinsically female labour is simpler and less valuable than male work. ${ }^{148}$

Ronnie J. Steinberg's extensive research on job evaluation programs, and specifically the Hay system, reveals that this "organizational practice" has two significant weaknesses. ${ }^{149}$ One, all work is assessed on the premise that management jobs are the most complex positions in any organization and thus the "distinctive" content of all other work automatically has a lower value; two, the system reproduces the historic discrimination against certain jobs through the continued use of factor definitions and weights that favour the managerial or supervisory work traditionally done exclusively by men and render invisible the knowledge, thinking and responsibilities required to perform the jobs traditionally done by women. ${ }^{150}$ In particular, job evaluation systems recognize formal credentials but not the "know how" gained through experience or on-the-job training; the autonomous decision-making of workers in lower-level positions is downgraded; and weight is not given to "emotional" labour because supervising subordinate staff is more complex and earns a higher wage than working directly with

\footnotetext{
${ }^{146}$ Henry Phelps Brown, The Inequality of Pay, (Oxford: Oxford University Press, 1979), 18.

${ }^{147}$ Steinberg, "Gendered Instructions," 386.

${ }^{148}$ Ibid.

${ }^{149}$ Ibid.

${ }^{150}$ Ibid., 388.
} 
clients or patrons — smiles are not rewarded. ${ }^{151}$ As a result of such "shortcomings," systemic pay inequities are perpetuated. ${ }^{152}$

McEown finished the initial assessment of jobs at Carleton based on the Hay system sometime in late 1967 or early 1968 and her review identified and valued the administrative/management job class as well as two core areas of support work at the university: administrative and technical. ${ }^{153}$ Although it is unclear whether this system was fundamentally changed between 1968 and 1975, when Pat Finn prepared the first official report on the status of women (students and support staff) at Carleton for President Oliver in 1975, she discovered that the distribution and compensation for work in these two classes was clearly biased in favour of work done by men. ${ }^{154}$ The 407 administrative support staff were overwhelmingly female (83.9\%) and employed in jobs that were consistent with the $20^{\text {th }}$ century definition of clerical work including cashier, clerk, typist, secretary, bookkeeper and stenographer. ${ }^{155}$ These jobs had an annual salary scale that

${ }^{151}$ Ibid., 391.

${ }^{152}$ Ronnie J. Steinberg, "Emotional Labor in Job Evaluation: Redesigning Compensation Practices," Annals of the American Academy of Political and Social Science,561 (1999): 143. Steinberg points out that some of these shortcomings are due to the fact that because the work categories upon which the program was based were industrial rather than service-oriented or technical, i.e., found in male dominated workplaces.

${ }^{153} \mathrm{I}$ am assuming that the categories that Finn reported in 1976 were similar if not identical to those that Margaret McEown had developed in the 1960s. Research such as Steinberg's has shown that Hay factors and weights remained remarkably stable from the 1940s to the 1980s and the current job classification process includes job descriptions that are broken down into major categories (complexity, accountability, etc.) that are similar to those used in the Hay system.

${ }^{154}$ In her oral history, Finn remembers that the job classification system at Carleton was always changing. However, it is possible that refinements to the job classifications themselves were still modelled after those used in the Hay factors. As reported in the November 22, 1974 issues of This Week Times Two, President Oliver established the President's Advisory Committee on Equal Rights for Women and Men at Carleton University that month. The top priority of the committee was to "review and document the current situation and practices with respect to equality of treatment of women and men of the faculty, staff and study body." Pat Finn was given responsibility for writing the report, perhaps from Jill Vickers who became the chair of the committee in the following year. "Equal Rights Committee Formed," This Week Times Two (Friday, November 22, 1974) 1, FN 3, Chapter 2; P. Finn, oral history.

${ }^{155}$ P.A. Finn (Chartier), Report on the Status of Women at Carleton University (Students and Support Staff, n.d., 14. There is no date but in her oral history, Finn indicated that the report was submitted to President Oliver in 1975. 
began at $\$ 4,400$ and ended at $\$ 12,600$. Those doing the 120 technical support jobs were predominantly men $(85.7 \%)$ and employees in this class included animal, audio visual, chemical and electronics technicians in addition to graphic artists and the "pool service person." ${ }^{, 156}$ Their salary scale began at $\$ 4,500$ and ended at $\$ 16,600$. Regardless of the differences in the nature of work and required qualifications in these two categories, Finn concluded that, on average, female support staff had more years of overall work experience as well as more years in their current jobs but that their average salaries were lower than those of men doing equivalent work. ${ }^{157}$

Although Finn did not define the nature of technical work in her report, the type of jobs she included in this category suggest that the definition being used at Carleton might have been compatible with later understandings of this form of employment. Technical work has been characterized as crossing the boundaries between "craft and science" and is done by professionals and scientists with highly specialized training in a variety of disciplines such as chemistry, biology and engineering. ${ }^{158}$ This work is thus considered specialized and complex in terms of the key factors of "know how," creative thinking and accountability ${ }^{159}$ but has also been identified as a "cultural anomaly" because it depends on both "mental and manual skills." ${ }^{160}$ While many jobs could be considered technical in nature, generally the category excludes classic clerical and blue-collar work and technical workers have maintained the complex status of their work through a "hiving off" process that delegates the simpler, more routine elements of many jobs "to somewhat less well

${ }^{156}$ Finn (Chartier), Status of Women, Statistical Breakdown of Personnel Job Postings.

${ }^{157}$ Ibid., 2.

${ }^{158}$ Stephen R. Barley and Julian E. Orr, "Introduction: The Neglected Workforce," in eds. Stephen R. Barley and Julian E. Orr ,Between Craft and Science, Technical Work in U.S. Settings (Ithaca and London: ILR Press, an imprint of Cornell University Press, 1997), 1-19.

${ }^{159}$ Ibid., 12

${ }^{160}$ Ibid., 7. 
trained" technicians. ${ }^{161}$ As a result, the support work of technicians, such as that being done at Carleton, has been both "respected and denigrated" because although they might have more formal training than other support workers, these employees do not have the credentials, knowledge and autonomy of full-fledged technical staff. ${ }^{162}$

At Carleton a significant number of technical support workers in the 1960s seem to have been employed in the science and engineering faculties, particularly as demonstrators. ${ }^{163}$ From the 1950 s to the end of the 1960 s, the Board recorded the hires, promotions and resignations of these employees under "instructional staff" but by the 1960 s, they had effectively been redefined as non-academic support staff. It is unclear what qualifications were required to do this technical work at Carleton in the 1960s but by the 1970 s employees with undergraduate degrees were being hired. Ian Babcock earned a Bachelor of Science in biology from Carleton in 1973 and, after part-time work as a chemistry research assistant for Professor Peeter Kruus, he was hired in 1974 as a full-time demonstrator in the same. ${ }^{164}$ In this job he had a number of responsibilities that required technical skills and knowledge.

[I] was in charge of setting up the lab for the experiments that the students would be doing, and answering their questions, and supervising the student lab demonstrators who were hired to work in that role ... they needed somebody to do the setup, the clean-up, organize things, prepare the chemical reagents and solutions and things like that. ${ }^{165}$

Technicians in other organizations might have found that their work was treated as inferior relative to technical staff but certainly some faculty members at Carleton

${ }^{161}$ Ibid.

${ }^{162}$ Ibid., 13.

${ }^{163}$ Based on my analysis of the Carleton University Board minutes from 1942 to 1973.

${ }^{164}$ Ian Babcock, retired support staff, Carleton University, in oral history interview with the author, May 27, 2011. Babcock became one of two CUSSA Zone 12 representatives in early 1975. "Council Notes," The What? 2, no. 2 (n.d.): 2, FN 13, Chapter 1.

${ }^{165}$ I. Babcock, oral history. 
respected their support staff employees. During the "off season" Babcock found that, as a result of his qualifications and "abilities,"166 he could be reassigned to research projects and engineering professor David Coll worked with many technicians and technologists who he regarded with high esteem.

In an engineering team ... all our people were technologists ... they are sort of ... skilled support workers. And they built the things after the concepts that the engineer makes up. It's the technologists who created it. And they were essential parts of the teaching as well, and undergraduate labs, and grad labs. And so we always treated them as colleagues. ${ }^{167}$

There was a second key group of technical workers on campus: the "library assistants." Although they do not seem to have been included in the technical support staff category by the official Carleton job evaluation program, Pat Finn did a random sample of CUSSA members at the same time she prepared the status of women report and found that in 1974 there were four levels of in the library assistant category (LA2 to LA5). ${ }^{168}$ Their occupational status as support staff in the early 1970 s seems to have been similar to that of the science and engineering technicians and directly influenced by the attempts of librarians to establish the professionalism of their own work. Canadian community colleges had begun to offer training programs for nonprofessional library staff in the mid-1960s. ${ }^{169}$ Three technical programs were available in 1967, including one at Lakehead University in Thunder Bay, Ontario, ${ }^{170}$ and by 1970 students in six provinces had access to similar "pre-service" courses - the year that the chairperson of a library

166 Ibid.,

167 D. Coll, oral history.

${ }^{168}$ Finn (Chartier), Status of Women, Table 5 (n.p.). Of the fifty-two library assistants responding to Finn's survey, $86.5 \%$ (forty-five) were women who, even at the LA 5 rank, made a lower average salary than their male counterparts.

169 Jean Weihs, "Library Technicians in Technical Services," Library Mosaics (November/December 2004): 8-10. Weihs was the director at Seneca College from 1969-1986.

170 Jean Riddle Weihs, "The Library Technician," in Spencer Garry and Garry, Canadian Libraries in Their Changing Environment, 422. 
technician workshop in Thunder Bay declared to attendees that their occupational movement was "coming-of-age." "171 The Canadian Library Association (CLA) produced curricula guidelines for this training that were designed to ensure that graduates were "job ready." As per these guidelines, the CLA recommended that programs include general academic courses as well as "tools of the trade" such as the less complex aspects of copy cataloguing, ${ }^{172}$ other "related technical topics" and basic office procedures. ${ }^{173}$ Graduates were typically hired to do "routine original descriptive cataloguing" and clerical work such as "serials check-in," although they could also find themselves supervising staff doing even simpler clerical tasks. ${ }^{174}$

Despite the role that the CLA played in encouraging this new type of training, some professional librarians opposed the hiring of college graduates and apparently those at university libraries were particularly hostile. ${ }^{175}$ Weihs has suggested that such opposition could have been partly due to a reluctance on the part of librarians to give up some traditional responsibilities but also because "universities had lots of people available and willing to work or modest wages" $" 176$ and some of these individuals would be hired as assistants and actually had a university degree but no formal library training. ${ }^{177}$ Nonetheless, other professionals recognized the value in relinquishing "routine" tasks that did not necessarily require high levels of specialized skills. In fact, the college programs became available during the same period that organizations such as

${ }^{171}$ Campbell, Allen and Irene Dawson, eds., The Library Technician at Work: Theory and Practice. Proceedings of the Workshop held at Lakehead University, Thunder Bay, Ontario, May 8-9, 1970, (Thunder Bay: Lakehead University, 1970): 19, 4.

\footnotetext{
${ }^{172}$ Ibid.

${ }^{173}$ Weihs, "The Library Technician," 423-24.

${ }^{174}$ Ibid.

${ }^{175}$ Weihs, "Library Technicians in Technical Services," 9.

${ }^{176}$ Ibid.

${ }^{177}$ Ibid.
} 
the IPLO were pushing for the greater professionalization of librarianship in Canada, suggesting that the emergence of the trained library technician could have effectively been yet another example of the "hiving off" or separation of simple, less skilled tasks from those that were considered more complex and essentially technical in a given occupation. As Dan Sudar, the director of Lakehead's School of Library Technology, reiterated at the 1970 library technician workshop, "Much of what Librarians have done in the past will be done by Library Technicians in the future while the Librarian himself moves on to a role that will demand efficient in the emerging knowledges of information and human understanding.",178

Despite the administrative efforts to quell discontentment with new salary scales, support staff continued to be unhappy with working conditions. In particular, young female administrative support employees began to publicly question workplace inequalities. Like professors and librarians, they were informed not only by their own backgrounds and individual experiences as well as by the change politics of the mid- to late 1960s. Although none of the commissioners of the Royal Commission on the Status of Women, represented the Canadian workers' movement, labour activist Grace Hartman prepared a brief for the panel members on behalf of CUPE and was also contributing to a revitalization of the Canadian labour movement by organizing millions of women and men working in the public sector, including many in public libraries and some university libraries. ${ }^{179}$ In particular, library technical workers at Queen's University had dissolved

${ }^{178}$ D.D. Sudar, "Education for Librarianship-A Personal View," (CLA Workshop), in The Library Technician at Work, 19. Apparently Mr. Sudar was quoting from a recently published editorial in the Library Journal.

${ }^{179}$ Crean, Grace Hartman, 79-84; Heron, The Canadian Labour Movement, 97. 
the Non-Professionals Association and become CUPE Local 1302 on July 1, 1970. ${ }^{180}$ This decision was of great interest to a cohort of young library assistants at Carleton whose "feminist stirrings and radicalism" motivated them to improve what they perceived to be unjust labour practices in the university library. In 1971, support staff made an initial, concerted attempt to unionize at Carleton.

\section{Organizing Support Staff at Carleton}

Part A. Mobilizing Library Workers: "We Saw a Situation that was Unfair" Carleton University library unionist Sylvia Gruda and American suffragette Maud Malone could never have met but if they had, they would have discovered a shared passion: equitable working conditions for female library workers. ${ }^{181}$ Malone was one of the founders of the Library Employees' Union of Greater New York, which was established in 1912. ${ }^{182}$ As explained in Chapter 1, this was the first library union in North America. It formed at the time when library employees widely recognized that the majority of library staff was women and both female librarians and library assistants were chronically disadvantaged relative to their male colleagues due to the sexual division of labour within libraries that led to low pay and few promotion opportunities for women. Malone and her fellow union members, rejected the "elitist" professionalism and preferred by librarians, arguing that changes such as higher educational standards would

${ }^{180}$ Richardson, “The Douglas Library in 1971." See also Mudge, "Bargaining Unit Composition,” 19. According to Mudge, there were seven library support staff unions in Ontario universities by 1976: Lakehead University (1968), Queen's University (1970), University of Toronto (1973), Guelph University (1974), York University (1975), Carleton University and University of Windsor (1976), 19. There were also seven public libraries with support staff unions.

${ }^{181}$ Maud Malone died in 1951 at the age of 78 in the United States. Catherine Shanley, "The Library Employees' Union of Greater New York, 1917-1929," (doctoral thesis, Columbia University, 1992), 121.

${ }^{182}$ Shanley, "The Library Employees' Union." Shanley indicates that there were no more than twentyfive members in the union. 
create further divisions between the better-educated librarians and the library assistants who often had years of on-the-job experience but little or no formal training and were already amongst the lowest paid of library workers. Instead, library staff should align themselves with the working class and fight to improve the status of women by gaining "equal pay for equal work" for all non-administrative employees. Union representatives even took this issue to the annual conference of the American Library Association several years in a row. Each time, however, their ideas and motions regarding "equal pay" for men and women proved to be too controversial for other library workers and the union was eventually disbanded in $1929 .{ }^{183}$ Gruda's first efforts to unionize support staff at Carleton met a similar fate-albeit more swiftly.

When she finished high school in 1968, Gruda wanted to work at the Carleton library. ${ }^{184}$ However, although she went for an interview at the university she was not hired and, over the next three years, she found clerical work locally, in the private sector and at the federal department Veterans Affairs, and also did some waitressing. ${ }^{185}$ These early experiences contributed to her later commitment to labour activism, particularly her period of employment at the Mutual Life Assurance Company, which in her opinion was "negative" due to a "horrible working atmosphere.","186

The first job I had out of school was for a ... private insurance company [that provided] ... the medical insurance for public service workers. And you were given a test ... and I actually could have been an underwriter but I didn't do very well on that and I ended up being a file clerk ...in the file clerk area there were a lot of young women and we used to have a ball, but the place was terrible because

\footnotetext{
${ }^{183}$ William Warner Bishop, "The American Library Association. II. Fragments of Autobiography," The Library Quarterly 21, no. 1 (Jan. 1951), 35-41. Shanley, “The Library Employees' Union,” 243-44.

${ }^{184}$ Sylvia Gruda, retired support staff employee, Carleton University, in oral history interview with the author, March 17, 2011; Sylvia Gruda, e-mail to the author, November 8, 2013.

${ }^{185}$ Ibid.

${ }^{186}$ Ibid.
} 
they would actually ring a bell ... you had to be at your desk when the bell rang ... "no questions," it was a very strict thing. ${ }^{187}$

Despite the advice from her guidance counsellor, who had cautioned Gruda that not

"everybody has to go to university," she began to study part-time at Carleton the same year she graduated from high school—a decision that proved beneficial. When Gruda reapplied at the library for full-time work in 1971, she had "taken Spanish and French and was taking Russian" and this knowledge of foreign languages helped her get a job in the serials department where she received and processed academic publications "from all over the world." 188 She felt privileged to work at Carleton where she found the environment decidedly more pleasant than that of the insurance company, even though her new job was considered transitional and "the kind of job people didn't stay at." 189 The process of receiving and sorting serials was manual and former head of Carleton's serials department, Valerie Swinton remembers that "juniors" ensured that all of this work got done.

We had huge KARDEXs and [there were] ... people sitting in stalls and ... they had responsibility for a certain part of they checked in, unpacked the books and checked them in. They were sorted, everybody took turns doing that, and then they checked them into the KARDEX record. ${ }^{190}$

Although the work was routine in nature, Gruda found it "cool" and also appreciated the opportunity to not only eventually take on supervisory responsibilities and eventually

${ }^{187}$ Ibid.

${ }^{188}$ Ibid.

${ }^{189}$ Ibid.

${ }^{190}$ V. Swinton, oral history. In a 1995 article of serials automation, American librarian Sarah D. Tusa described the KARDEX" time-consuming. "Through a system of clips, colored stickers and various codes pencil marks, the status of each individual publication was discernible by trained serials staff ... for example, a purple clip [could] indicate when the next issue [of a serial] was expected ... Such a system was not easily accessible by the uninitiated. The KARDEX system was also slow. Since the file was arranged in alphabetical order by title, it was necessary to alphabetize the newly received issues in order to progress smoothly through the checkin process. A check-in clerk then wrote the date of each issue and the date of receipt in the appropriate space of the check-in card ... ." Sarah D. Tusa, "Serials Automation," Acquisitions Librarian 13/14 (1995), $55-56$. 
complete and undergraduate degree in sociology in $1980 .{ }^{191}$ Moreover, she enjoyed the company of her co-workers and seems to have trusted some of the management staff including her direct supervisor, who became a friend, and Swinton, who had overall responsibility for the department.

Valerie Swinton ... was a really open-minded librarian, I wouldn't say she fit the stereotype of librarian at all, she was a real go-getter ... And our serials department was made up of four ... KARDEX clerks ... And we had a supervisor, and that was my friend, Jellowe from Barbados ... And we actually had a pretty good atmosphere ... we were all young girls or women who ... were working our way up in terms of studying part time. ${ }^{192}$

While Gruda's early experience at Carleton as a library assistant was reminiscent of that of the earlier cohort that included Margaret McEown and Evelyn Aldridge—she did not have any specialized post-secondary training and was taught on-the-job-library assistants at that time also included new employees who had completed the specialized technical training available at the newly established library programs offered at Canadian colleges. Ann Newton was one of the early graduates from the pioneering one-year technical program at Lakehead University and finished in 1969 with both her diploma and an additional year of arts courses. ${ }^{193}$ In her first job after graduation, she worked in the reference department at the Carleton library, taking shifts on the information desk as well as preparing library guides. Although her orientation included a mandatory session on "bibliographic searching" (which she did not perhaps need) she revelled in the

${ }^{191}$ S. Gruda, email to the author, November 18, 2013.

${ }^{192}$ Ibid. Jellowe Clarke went on to become a CUSSA zone representative for the Food Services group in 1975. CUSSA, Minutes of Council of Representatives Meeting, Wednesday, July 9, 1975," Carleton University Support Staff Association fonds, CUSSA-002-2, Carleton University Corporate Archives, Ottawa, Ontario.

${ }^{193}$ Ann Newton, retired support staff employee, Carleton University, in oral history interview with the author, July 6, 2011. 
additional and varied work she was given to do-assignments that contrasted to some extent with the more routinized work of the KARDEX clerks. ${ }^{194}$

In those days, which was pre-union, we used to do all kinds [of work] ... we would get called on to help out if there was shortages in different departments ... It wasn't like working in any of the government offices [where I later worked] ... [where] you were basically doing one thing, and you never really knew what was happening.

Newton was given a wide exposure to the work done in different departments throughout the library, but nonetheless as support staff she had limited control over her work. Like Gruda, however, Newton respected her supervisors and does not seem to have begrudged her limited personal autonomy or her supervisor's authority to determine the rhythm of the workday — which did not include ringing bells but did lead to a structured work environment. Perhaps one of the most important mitigating factors that prevented Newton from feeling resentment was that her supervisor seemed to respect the skills and contributions of her support staff.

Sheila was actually the one ... that impressed upon me and others in the unit the importance of being responsible ... you have coffee breaks and you have lunch hour[s]. But Sheila was a bit of a dragon when it came to things like ... breaks. It was a 15-minute break and ... If it's an hour lunch, it's an hour lunch ... And we would hear if it was seventeen minutes. But you know ... she was very, very good as a manager. And she made you feel like you were a vital member of the team ...There was none of this, "Oh these are the professionals and you're the para-professional." It was very different ... you didn't get any of that prima donna stuff. ${ }^{195}$

A sense of friendly workplace solidarity also contributed to Newton's overall satisfaction with her work at Carleton, some of which developed during those 15-minute coffee breaks that were often held in the staff lounge. These coffee breaks could be one of the

194 Ibid.

195 A. Newton, oral history. Sheila Bradley is a professional librarian and was the head of Reference Services when Newton first worked at the Carleton University Library. Ann Newton, e-mail to the author, November 18, 2013. 
highlights of the working day for library staff and all members of the staff would attend, from the "stack people" to the chief librarian. ${ }^{196}$

We had a coffee lady ... Monica Cruikshank ... [who] was working in the bindery... she also provided coffee in the morning and the afternoon ... and there was tea and there were cookies. She'd get all kinds of different types of cookies, really fattening ones. And, but, we would just go and we would pay for our coffee ... But what we paid for our coffee, you see, would basically give her the money that she needed to buy the supplies. ${ }^{197}$

Interesting work, well-liked supervisors and on-the-job friendships were not enough, however, to prevent some library assistants from recognizing and resenting "injustices" in their workplace. Gruda was grateful to be working at the university but she was not blind to the disadvantages of being a support staff employee at Carleton. In particular, salaries were inadequate and some employees like Gruda were forced to make choices that could have long-term consequences.

The pay was really bad ... I know there was inflation and everything [and] I was making $\$ 3,000$ a year ... [for] a lot of young people who started working at Carleton at the time, you really couldn't live out on your own and exist ... it wasn't mandatory to join the pension until you were 30 , and I was in my early 20 s and I really needed the money, and my dad said ... "Join the pension" and I didn't ... that was one time I didn't listen to him which was unfortunate. ${ }^{198}$

Some of the library assistants, influenced by "feminism and also the trade union movement," identified the problem as an issue of gender inequity. ${ }^{199}$ Overt inequalities between men and women might not have necessarily existed within a library department but did exist on campus. Gruda became increasingly conscious of these "injustices," in part through relationships she had with library co-workers. "I ended up making a friend,

\footnotetext{
${ }^{196}$ Ibid. None of the library staff that I interviewed could remember exactly when Monica Cruikshank became responsible for providing coffee but all remembered her buying snacks and serving coffee.

${ }^{197}$ Ibid. The ritual of staff taking a daily coffee break together has persisted in one form or another for some staff members until the present. For example, the staff members in Reference Services still go for coffee at approximately 10 a.m., although not in the staff lounge.

${ }^{198}$ S. Gruda, oral history.

${ }^{199}$ Ibid.
} 
and she was part of the Company of Young Canadians ... so she still had that training to say, "Oh, looking [sic] ... at a social situation and how can we improve it?" 200 She and colleagues were particularly aware that some management staff sanctioned the unfair advantages given to male employees.

[In] the serials department, I would say we were bright young women, not being paid a lot, we all worked at the back room opening up all the journals ... The fellow that was delivering mail at the time, we were level 2's, and he was a level 4 201

I remember once asking my supervisor, "Why is the mail clerk a Level 4 and I'm a Level 2?" and the reply was, "Because he has to lift up boxes." 202

Faced with some labour practices that they considered intolerable, Gruda and a small group of fellow library staff decided to try and form a union because "we weren't unhappy, we just saw a situation that wasn't fair and felt that we had to do something about it." ${ }^{203}$ In 1973 the number of employees totalled $187 .{ }^{204}$ Given that approximately thirty-five of these staff members were librarians, it is reasonable to suggest that the organizers were probably facing the challenge of mobilizing over 100 people. They do not, however, appear to have been unduly daunted by this task.

Sometime in the fall of 1971, the group approached CUPE to discuss the possibility of organizing a local. ${ }^{205}$ They may have considered contacting other labour organizations, particularly as the group had input from "students ... because we're talking about the radical times, who also got involved [with] who the people in the library should

200 Ibid.

201 Ibid.

202 Ibid.

203 Ibid.

204 “Humble Beginnings," Carleton Library Staff. Newsletter 1, 4 (Nov. 1973), Library History Collection, LSC-040 2009-42, Carleton Library Staff Newsletter, 1973-1974, Carleton University Library Archives.

${ }^{205} \mathrm{~S}$. Gruda, oral history. There is no conclusive evidence of the date on which library organizers approached CUPE but all the documentation is dated November so I am presuming that the CUPE campaign began soon after the organization was first approached. 
unionize with. ${ }^{206}$ At the very least, however, CUPE seems to have been perceived as a logical candidate because the technical workers at the Queen's University Library had certified their staff association the previous July and now had 190 members in CUPE Local $1302 .^{207}$ Some of the Carleton library staff might have also realized that, in the early 1970s, CUPE organizers had successfully certified a significant number of public library unions as well as workers at the Lakehead University library. ${ }^{208}$ In addition, they could have had some inkling of the depth and breadth of CUPE's membership. By 1965, the overall rate of unionization in Canada had begun to rise again after falling in the $1950 \mathrm{~s}^{209}$ and between 1965 and 1970, the rate of Canadian women joining unions nationwide had increased from 16.6 to $22.6 \%,{ }^{210}$ many of those women belonged to CUPE locals across Canada. ${ }^{211}$ Regardless of their original reasoning, the group reached out to the national union in the fall of 1971 and "J. Ed Scott, Representative" was assigned to their case. $^{212}$

${ }^{206}$ S. Gruda, oral history. There is no evidence to indicate whether these were students in the library (either part-time or full-time) or students who simply approached library staff independently.

${ }^{207}$ Richardson, "The Douglas Library," 1.

${ }^{208}$ In background information provided to an IPLO panel held in April 1975, CPUE had thirty-one of thirty-four agreements in Ontario public libraries and ten of twenty-one agreements in Ontario university libraries. CUPE, Background Material, 2, in the author's possession. According to Charlotte Mudge, by 1976, 62\% of Canadian public libraries employed workers with a CUPE contract. Mudge, "Bargaining Unit Composition,"17. In her history of CUPE Local 1302, Richardson indicates that the local had "about 190 members."

${ }^{209}$ Heron, The Canadian Labour Movement, 90.

${ }^{210}$ Linda Briskin, "Women and Unions in Canada: A Statistical Overview," in Union Sisters. Women in the Labour Movement, ed. Linda Briskin and Lynda Yanz, (Toronto: The Women's Press, 1983), 33.

${ }^{211}$ Ibid. Briskin's statistics are from 1979: CUPE is the largest national union with 252,040 members and $43.5 \%$ are women.

212 J. Ed. Scott to Carleton University Library employees, November 19, 1971, Office of the President fonds, Acc. \#1997-21, PRES-233, Collective Bargaining-Collective Bargaining Agreements/Documents 1975-76, Part I, Carleton University Corporate Archives, Ottawa, Ontario, 1975. Scott was a wellrespected employee of CUPE. According to a news release dated October 1, 2010, Scott established the CUPE Kingston office, which is named in his honour. Media Advisory: CUPE Kingston Office to Honour Long-Time Kingston Labour Activists-Building Dedication Ceremony on Monday October 4, accessed on November 10, 2013, http://www.marketwired.com/press-release/media-advisory-cupe-kingston-officehonour-long-time-kingston-labour-activists-building-1328349.htm. Scott died on June 7, 2013 and, in the 
Gruda conjures up a vivid memory of Ed Scott, who she describes as "sort of like a truck driver, Elvis Presley type.”213 Apparently Scott's campaign strategy was very straightforward: library activists were to "Get them in the union hall and I'll have them all signed up." 214 Gruda and her fellow union supporters "kind of took that for word" and did not question Scott's role as the lead union organizer. In turn, Scott does not seem to have provided a job description for his work as the union representative but Eileen Sufrin, a veteran organizer who helped lead the unionization drive at the T. Eaton Company just after World War II, suggests that the paid organizer's primary responsibility is persuasion.

Above all, an organizer must be able to communicate: the primary function of the job is to persuade workers to join and become active in a union. As well as being able to put one's prospective members at ease, it is important to win their trust and respect. It is not enough to be armed intellectually with all the reasons for forming a union; the organizer must be able to impart them to members, and to inspire as many as possible to assist in signing up their co-workers. ${ }^{215}$

Whether Scott agreed completely with Sufrin's definition of union organizing or not, he did began his certification campaign with a letter to Carleton non-professional library staff, dated November 24, urging them to attend an upcoming off-campus meeting on November 29 to discuss the possibility and advantages of unionizing. ${ }^{216}$ Initially, Scott's efforts to mobilize widespread support for unionization seem to have been successful. In his December 2 follow-up letter to library staff, he reported that "many" of the library workers who had attended the earlier meeting had signed CUPE membership cards and were preparing to move forward with a formal certification campaign. Seemingly on the strength of this initial interest, Scott hosted a second information session on December 16

photo that accompanies his online obituary, one can see the resemblance to Elvis Presley. Accessed on November 10, 2013 (http://yourlifemoments.ca/sitepages/obituary.asp?oid=712535).

${ }^{213}$ S. Gruda, oral history.

${ }^{214}$ Ibid.

${ }^{215}$ Eileen Sufrin, The Eaton Drive. The Campaign to Organize Canada's Largest Department Store. 1948 to 1952 (Toronto, Montreal, Winnipeg, Vancouver: Fitzhenry \& Whiteside, 1982), 37. ${ }^{216}$ Ibid. 
so that those who had not attended the first meeting could learn more about unionization in general and CUPE in particular. ${ }^{217}$ Subsequently, pro-union library staff scheduled a third meeting for early January that included the opportunity for Carleton library staff to discussion the experience of unionization with two representatives from the Queen's CUPE local. ${ }^{218}$ It is possible that the meetings in December and January were held because enthusiasm for unionizing was growing but it is more likely that at least the third meeting took place to counteract the concerted efforts of an "anti-union" group within the library to prevent certification.

After the November 29 meeting, Gruda and her fellow activists quickly found themselves embroiled in a "big debate for and against" unionization. ${ }^{219}$ At the heart of the conflict was the issue of the occupational status of women and the tensions amongst library employees at this time foreshadowed those that would split support staff during the CUSSA certification drive. In his initial letter to potential union members, Ed Scott framed collective bargaining as a strategy for non-professional library staff to improve their standing within the library operations vis-à-vis that of the librarians. He made no reference to class or gender issues but instead his strategy to build support for unionization was to normalize what would be a significant change in internal labour relations in terms of two factors. One, the positive experience of Carleton library staff peers, the library workers at Queen's who were no longer "second-class citizens" as a result of effective collective bargaining; and two, constitutional autonomy of CUPE

${ }^{217}$ J. Ed. Scott to Carleton University Library employees, November 24, 1971, Office of the President Fonds, PRES-233, Collective Bargaining-Collective Bargaining Agreements/Documents 1975-76, Part I, Carleton University Corporate Archives, Ottawa Ontario.

${ }^{218}$ Letter to library staff, January 6, 1971, Office of the President Fonds, PRES-233, Collective Bargaining-Collective Bargaining Agreements/Documents 1975-76, Part I, Carleton University Corporate Archives, Ottawa, Ontario.

${ }^{219}$ S. Gruda, oral history. 
locals and the success that these unions had had in achieving better working conditions without striking. ${ }^{220}$

His logic did not, however, convince those opposed to unionization to abandon their concerns, and a group of anti-union staff quickly organized their own campaign to discourage co-workers from signing membership cards. These employees reached out to other library staff with The Disadvantages of CUPE at MacOdrum Library, a handout that they distributed on December 2- the same day that Scott wrote to invite library staff to a second information session. ${ }^{221}$ In this statement of their objections, the anonymous authors flatly rejected the idea that they were "second class" library employees. Focusing strictly on the potential material benefits of unionization, they argued that staff would lose more than they would gain: ${ }^{222}$ collective bargaining would not ensure a strong position because "the world does not come to an inconvenient halt when a library is nonoperating,",223 trying to raise wages at a time when the university had a "depleted budget" would only contribute to a cycle of rising prices; CUPE members had actually recently received lower salary increases $(7.5 \%$ per year) than those paid to some of the Carleton staff in the same period, which included merit pay and substantial cost of living increases ( 3 to $15 \%$ ); finally, union dues simply went to pay the salaries of union leaders or the strike pay of other union members such as "garbage collectors," with whom, by

\footnotetext{
${ }^{220}$ Scott, to Carleton University Library employees, Carleton University Support Staff Fonds, CUSSA-001-08, Carleton University Corporate Archives. Ironically, as Linda Briskin has shown, the years between 1975 and 1979 were ones where there was a "high incidence" of strikes by CUPE locals. Linda Briskin, "CUPE on Strike, 1963-2004," Just Labour: A Canadian Journal of Work and Society 10, (Spring 2007): 11.

221 "The Disadvantages of CUPE at MacOdrum Library," (December 2, 1971), Office of the President Fonds, PRES-233, Collective Bargaining-Collective Bargaining Agreements/Documents 1975-76, Part I, Carleton University Corporate Archives. The name of the Carleton University library building is the MacOdrum Library.

${ }^{222}$ Ibid.

${ }^{223}$ Ibid.
} 
implication, library staff had no "community of interest. ${ }^{224}$ Moreover, they argued that Carleton library staff already had the very advantageous working conditions that CUPE was promising to deliver through labour negotiations such as guaranteed wage rates, job security, grievance procedures and overtime pay. In short, unionization was not needed to improve the status of staff, nor was it an appropriate strategy for managing workplace relations in the library.

The anti-unionists also organized a meeting in the library staff lounge for nonprofessional library workers where Bursar Albert $(\mathrm{Ab})$ Larose had been invited to speak about the university budget, which President Oliver had discussed at the special General Faculty Board meeting held on November $19 .{ }^{225}$ This meeting appears to have taken place sometime between December 2 and December 16, and provoked a quick, retaliatory response from the union organizers. Now communicating directly to their co-workers, rather than through Scott, pro-unionists positioned collective bargaining in terms of women's rights — not just a strategy for attained a fair wage but also for a gaining meaningful role in workplace decision-making. In an open letter to staff on December 16 and a leaflet distributed sometime in January, the "Group of Concerned Library Employees" tried to expose the "wrong information" that "doubters" were spreading by undermining Larose's authority and "exploding" the "anti-union myths."226 Less interested in any comments Larose might have made on the university's financial position, the union supporters questioned his assumption that staff and university administrators

${ }^{224}$ Ibid.

${ }^{225}$ Letter to All Non-Professional Staff in the Library, December 16, 1972, 1, Carleton University Support Staff Fonds, CUSSA-001-9, Carleton University Corporate Archives, Ottawa, Ontario. "Budget Blues," This Week Times Two 1, FN 3, Chapter 2. As discussed in Chapter 2 of this thesis, President Oliver indicated that the recent funding for universities announced by the province was inadequate and "puts the universities in an unhappy position."

${ }^{226}$ Seven Anti-Union Myths Exploded (In Two Easy Instalments), (n.d.), 1, Carleton University Support Staff Fonds, CUSSA-001-9, Carleton University Corporate Archives, Ottawa, Ontario. 
were engaged in positive relationship-building or that the appreciation senior staff had asked for the "input" of the "Women's Association.,"227 They challenged his credibility on the grounds that individual library staff members knew from first-hand experience that "the co-operativeness in attitude was not there" and that the input of women was not sought regularly over important issues such as the annual budget. ${ }^{228}$ Moreover, Larose did admit publicly that wages at Carleton were "very low"-so Carleton employees were not fairly paid and, although not everyone lived in a two-income family, even those who were "economically secure because they are married and can depend on a spouse's income" should receive a just wage. ${ }^{229}$ Co-workers were encouraged to recognize that the only way to find a "balance between administration and ourselves" was to act in solidarity and form a union. ${ }^{230}$ Most pointedly, the pro-union group admonished other staff not to "rely on the advice of friends or husbands ... ask questions for yourself. Listen and make a rational decision based on protecting your interests as a library employee.,231

In one of their last formal acts of persuasion, the pro-union group invited Mary

Oliver and Nancy Leitch of the Queen's University CUPE local to the meeting on January 6, 1972. ${ }^{232}$ Regardless of how "well qualified" these women might have been to address concerns about unionization or how strongly the pro-unionists argued their case overall, ultimately the certification campaign failed. The strong resistance amongst

\footnotetext{
${ }^{227}$ Letter to All Non-Professional Staff, (December 16, 1972), Carleton University Support Staff Fonds, CUSSA-001-9, Carleton University Corporate Archives, Ottawa, Ontario.

${ }^{228}$ Ibid. President Oliver's presentation on the university's financial challenges at the General Faculty Board in November had been reported in in a recent issue of This Week Times Two. "Oliver Explains Improved Deficit," This Week Times Two 4, no. 20 (Tuesday, November 28, 1972), FN 3, Chapter 2.

${ }^{229}$ Seven Anti-Union Myths, 2.

230 "Letter to All Non-Professional Staff," (December 16, 1972), Carleton University Support Staff Fonds, CUSSA-001-9, Carleton University Corporate Archives.

${ }^{231}$ Letter to All Members of the MacOdrum Library, (January 6, 1971), 1, Carleton University Support Staff Fonds, CUSSA-001-9, Carleton University Corporate Archives. This letter is dated January 6, 1971. However, based on the content of the letter as well as that of other documents related to this topic in the archival files, it appears that the letter should actually have been dated January 6, 1972.

${ }^{232}$ Ibid.
} 
library staff might have seemed remarkable to Ed Scott. After all, as fellow union organizer Eileen Sufrin points out, "it is generally true that interest in a union varies in inverse proportion to satisfaction with earnings and working conditions, ${ }^{233}$ so he might have assumed that Carleton employees would be supportive of unionization given that many were aware that "even the faculty is receiving the second lowest wages in the Province of Ontario.. ${ }^{234}$ Nor did Carleton staff face some of the barriers that historically had proven to prevent collective bargaining such as restrictive labour legislation (both federally and provincially) and either union or employer hostility. ${ }^{235}$ In fact, according to the union supporters, at the meeting with the bursar in early December, Larose "refused to make statements pro or anti-union" and indicated that the Carleton administrators had not trouble negotiating with the "maintenance men" who were already unionized. ${ }^{236}$ In addition, the staff appears to have been relatively homogenous in terms of culture and language — at the very least, everyone seems to have spoken English—and the library was a single workspace within the university so employees were centralized in one building rather than being spread out or fragmented in different units across campus, thus making communication comparatively easy.

For Sylvia Gruda, the explanation for opposition to unionization is simple: resistance reflected generationally different ideas about the status of women. Her observation then — and now—was that older, married women working at the library still

${ }^{233}$ Sufrin, The Eaton Drive, 65.

234 "Letter to All Non-Professional Staff," (December 16, 1971), 1, Carleton University Support Staff Fonds, CUSSA-001-9, Carleton University Corporate Archives, Ottawa, Ontario.

${ }^{235}$ See for example Heron, The Canadian Labour Movement, 89; Gregory Kealey and Bryan Palmer, "The Bonds of Unity: The Knights of Labor in Ontario, 1880-1900," Social History/Histoire Sociale, 14, no. 28 (Nov. 1981), 369-411; Sangster, "The 1907 Bell Telephone Strike," and Canadian Industrial Relations. The Report of the Task Force on Labour Relations, (Ottawa: Privy Council Office, 1968), 16-22.

${ }^{236}$ Letter to All Non-Professional Staff in the Library, December 16, 1971, 1, Carleton University Support Staff fonds, CUSSA-001-9, Carleton University Corporate Archives, Ottawa, Ontario. The maintenance men belonged to CUPE Local 910. 
believed that as wives they did not have to depend upon their own earnings but could rely upon their husbands, as the male breadwinners, to provide for the family. Young women on staff, regardless of marital status, were more radical and believed that they had an inherent right to equity in the workplace, which included fair wages and working conditions. Ed Scott might have agreed with her-traditionally union organizers had argued that women were hard to mobilize, although more recent research from Canada and the United States indicates that "women are as likely as men to support unionization. ${ }^{, 237}$ However, while the comments of both the anti- and pro-union library employees seem to validate this interpretation, the argument is perhaps incomplete. Gruda refers to the library as a "female work ghetto" but there were men, such as retired military personnel, working in support positions and apparently collecting public service pensions in addition to their salaries, so they too could have been disinterested in unionization. ${ }^{238}$ Plus, as Gruda would later discover, there were older married women working at Carleton who shared her unconventional views and there were younger women on staff at the library who were against unionization and whose beliefs were influenced by familial values that may or may not have been gendered. Ann Newton loved the "little family in the library" and would have loathed any conflict that disrupted this environment. However, she also opposed collective action because her father "was the military, and there's no unions in the military" and because, when she and her siblings

${ }^{237}$ Julie Guard, "Fair Play or Fair Pay? Gender Relations, Class Consciousness, and Union Solidarity in the Canadian UE," Labour / Le Travail 37, (Spring 1996): 149-77; Richard W. Hurd, "Learning from Clerical Unions: Two Cases of Organizing Success," Labor Studies Journal 14, no. 1 (Spring 1989): 31.

${ }^{238}$ S. Gruda, oral history. As reported in an April 1973 issue of This Week Times Two, Harry Thornton was the supervisor of the stacks department and he had " 14 full-time and 20 part-time stack-men" reporting to him. "Getting the Books Back," This Week Times Two 5, no. 24 (Friday, April 6, 1973), FN 3, Chapter 2. 
went to university, "our father told us not to get involved in protests, or sit-ins, or any of those things, because you never know when it's going to come back to haunt you.",239

In addition, the reference to "garbage collectors" in one of the anti-union handouts hints at occupational status as another factor in the anti-union campaign i.e., library staff may have regarded their work as more prestigious than that of manual, blue-collar workers such as sanitation workers, as had the first generation of clerical workers in the early $20^{\text {th }}$ century. ${ }^{240}$ Library employees were part of the first cohort of white-collar workers in Canada to organize and representatives from unions such as CUPE had to overcome the stigma of unions as blue-collar, working class organizations in order to successfully mobilize support. ${ }^{241}$ Whatever the overriding motives of each group, Gruda was initially very disappointed in the outcome of the library campaign but now views this result more positively.

The worst thing that happened was that ... we didn't get certified ... but I think [too] that was actually a blessing for the library because at the time we were trying to unionize on our own and ... when the Carleton University Support Staff Association was formed ... it was going to be a union of all employees, support employees of the university. So I believe that the library, being predominantly female, benefitted greatly to have jobs compared outside of the library. ${ }^{242}$

She did not have long to wait. The library campaign fizzled in early 1972 but at the same time that the pro-unionists in the library were running their union drive, employees in other parts of the university were also reaching out to each other to form a staff

${ }^{239}$ A. Newton, oral history. This is consistent with Elaine Sufrin's observation that during the Eaton drive, women were less likely to support unionization if their male relatives (or friends) did not. See for example, Robert A. Ventresca, “'Cowering Women, Combative Men?': Femininity, Masculinity, and Ethnicity on Strike in Two Southern Ontario Towns, 1964-1966," Labour / Le Travail 39 (Spring, 1997): $125-58$.

${ }^{240}$ Julie White, Sisters and Solidarity. Women and Unions in Canada, (Toronto: Thompson Educational Publishing, 1993), 9-10.

${ }^{241}$ See Chapter 3 of this thesis for further discussion of unions in libraries.

${ }^{242}$ S. Gruda, oral history. 
organization that would represent and negotiate their interests with senior university administrators.

Part B. Organizing Support Staff: "You Gotta Have a Union"

In November 1971 the following notice appeared in a Carleton University publication:

\section{Staff Organization}

A Carleton University Administrative/Secretarial Employees Organization is being formed. It hopes to become the collective bargaining agent for its members, (members to include administrative assistants, secretaries, stenographers, and clerical employees). It will consider matters relating to the general welfare and interests of the Organization including pension, medial and insurance plans, leave salary scales, etc.; and plans to establish a Personnel Review Board. A general meeting of the Organization will be held on Tuesday, November 30, 12:15 to 1:00 in Room 201, Paterson Hall. Anyone interested is welcome to attend. For further information please call $231-5530$ or $231-3861 .^{243}$

Pat Finn is sure that Judith Poitras, a secretary in Carleton's journalism department, had placed the announcement for the meeting that took place virtually at the same time that library employees were holding their own meetings. ${ }^{244}$ Like that union drive, Poitras's "meeting did not go well. People were not keen on the idea. Most of the women weren't keen on the idea, the older women." 245 Nonetheless, when she thinks back on the early 1970s at Carleton, Finn is convinced that these first efforts to unionize were symptomatic of the serious discontent that had been ripening over time for administrative and clerical staff, as it had for library employees.

${ }^{243}$ Staff Organization announcement, 1971, in the author's possession. I received the clipping from Pat Finn but there is no indication of the title of the publication in which it appeared.

${ }^{244}$ P. Finn, oral history. Judith (Judy) Poitras was hired as the secretary in the journalism department on August 14, 1967 at the annual monthly salary of $\$ 300$. CU, Minutes of the $189^{\text {th }}$ Meeting of the BOG, September 20, 1967, 16, FN 1, Chapter 1. She became active in CUSSA and in 1975 took on the role of chair of the Salary and Benefits Committee. "Council Notes," the What? 2, no. 2 (n.d.), FN 13, Chapter 1. 245 Ibid. 
Unions don't happen like some sort of disease you wake [up with] one morning and you gotta have a union. It's a reaction to bad management. [If] you don't have bad management, you probably won't have a union. But we did. A number of very odd things went on. ${ }^{246}$

As the above notice indicates, these "odd things" related to specific terms and conditions of work but, more generally, support staff were no longer satisfied with the process by which decisions were made regarding their employment. They wanted more direct input into decision-making and they knew that the existing staff association was not a labour advocacy group; they needed an organization that would engage in collective bargaining.

By the 1970s, Carleton non-academic staff worked across campus in a variety of academic and non-academic departments and represented a significant proportion of the total workforce. It is challenging to recreate the distribution of men and women in support staff jobs across units and job categories during these years as published demographic statistics for these employees from 1971 to 1972 are difficult to find. Nevertheless, based, on data for the period between 1973 and 1975, a pattern emerges that might be consistent with the nature of the workforce at the beginning of the decade: the majority of support staff were women, working in administrative jobs split roughly evenly between academic and non-academic units while the minority male employees worked almost exclusively in academic units as technical staff. In addition, for those employees in the administrative support category, roughly 50\% worked in the library. As noted earlier, women tended to dominate the lower paying jobs - a phenomenon also observed at other English Canadian universities, such as the University of Saskatchewan. ${ }^{247}$ Not only were staff spread out amongst departments at Carleton, they also were now working on a campus that was considerably larger than it had been in the

\footnotetext{
${ }^{246}$ Ibid.

${ }^{247}$ Makahonuk, “'In Union is Strength'," 30-43.
} 
early to mid-1960s, with the main administration building located at a distance from the "academic precinct." ${ }^{248}$ The size of the employee population and the dispersal of workers across a number of buildings located in a larger geographic area than in the early 1960s, led to a sense of separateness amongst support staff. Finn recollects that,

There was a distinction between the staff who worked on the academic side and the staff who worked on the administrative side, so mainly you knew people on the administrative side if you were on that side, or once we moved to Robertson, the other side of the tracks ... that tended to be the group you saw the most often. $^{249}$

In addition, unlike library staff members who could retreat to the staff lounge for their daily coffee breaks, the earlier cohort of employees who had the First Avenue basement cafeteria in which to meet, or the professors with their faculty club, most support staff did not have a central place on campus where they could socialize with colleagues during the workday.

There was Honest John's in the tunnel ... you could go there and pick up something, or you could go to the ... the lower cafeteria which is where Oliver's is [today] ... and ... later there was the Loeb, so one could go there for lunch ... But there wasn't [sic] a lot of venues. ${ }^{250}$

As they had done since the 1940s, support staff worked in departments that were organized hierarchically. Supervisory and/or managerial staff headed the non-academic units while faculty members chaired the academic departments, although supervision for the clerical and administrative staff seems to have been the responsibility of a departmental secretary or administrator such as Evelyn Aldridge. Bette Smith began her career as a stenographer in the sociology and anthropology department at Carleton in

${ }^{248}$ When I started working at Carleton University in 2001, this was how the academic quadrangle (which houses most of the main academic buildings) was identified in the maps for the underground tunnels on campus. The administration building is now called Robertson Hall.

${ }^{249}$ P. Finn, oral history.

${ }^{250}$ Ibid. 
1972. ${ }^{251}$ In her experience, although the departmental chair, Professor Muni Frumhartz, was "the boss" and could be counted on to intervene between clerical staff and professors if necessary, the departmental secretary delegated work and managed the work of support staff day to day.

The chair would be there for a number of years. There would be an assistant chair ... somebody who reported as a faculty member to the chair, and in terms of support staff, there was an administrative assistant ... Then you had the departmental secretary [Eleanor Currie] who was also the graduate secretary, the undergraduate secretary, and I believe the chair's secretary would be one down but still higher than the three stenos who were in the main office ... [the relationship with faculty] ... could be a little contentious ... depending on whether something was trying to be pushed forward ... into the work flow ... But that wasn't really up to us to sort out. That was up to Eleanor, and she was a very capable and diplomatic person. ${ }^{252}$

Similarly, laboratory technicians such as Ian Babcock would ultimately report to a faculty member although they too could have an immediate supervisor who was a non-academic and in the library, typically department heads were librarians with the exception of the stacks department. ${ }^{253}$

As previously mentioned, the administrative category included a range of clerical positions such as keypunch operator, stenographer and accounts clerk while the technical workers could be animal technicians, junior artist illustrators or storekeeper and a high school diploma seems to be the minimum required credential although some employees, such as Bette Smith and Ian Babock, had post-secondary education. ${ }^{254}$ Smith attended high school in Ottawa and after Grade 13 attended the local branch of the Willis Business

${ }^{251}$ In early 1975, Bette Smith became the CUSSA Zone 4 representative for the Carleton University Support Staff Association (CUSSA). "Council Notes," The What? 2. no. 2 (n.d.): 2, FN 13, Chapter 1.

${ }^{252}$ Bette Smith, retired administrator and former Carleton University support staff employee, in oral history interview with the author, June 11, 2011.

${ }^{253}$ FN 238 in this chapter re Harry Thornton.

${ }^{254}$ Finn (Chartier), Status of Women, Statistical Breakdown of Personnel Job Postings. Bette Smith did a diploma at the local Willis Business College while Ian Babcock had an undergraduate degree in science. B. Smith, oral history; I. Babcock oral history. 
College. ${ }^{255}$ She believes that this training provided her with specialized skills that she needed for the often time-consuming complicated stenographic work she was assigned.

Muni was a lovely man ... [who] could also go on at great length with his memos $\ldots$ and he was very particular. He didn't like mistakes being made. It could be three pages long and you'd have to do like six carbons ... So you had to be very careful because you didn't really have Wite-Out ${ }^{\mathrm{TM}}$ at that point. You had to go back and basically erase carefully all the copies and then put in another carbon piece to get it back in ... we had electric typewriters ... but there was no such thing as the erase tape at that point ... [and] we had quite a few who did ... statistical tables, very complex ones, and so if you're in business college you learn how to set these up ... there's a particular way of figuring it out. The computer doesn't do it for you, you had to measure things out, know how many spaces across the page you had to work with, and map it basically.

But you also had to remember that if you were doing statistical tables ... [and] had to be very careful when you were making corrections ... one professor .... said, (and I think it was Professor McFarlane) ... he was very annoyed with one of the stenos ... because what she was doing was ... just typing it over and handing it back to him, and he said, "Well, what is the number? Is it 675 or is it 665 ? I can't tell. This is ruined.” ... you, know, got to use your noggin here. So I do remember at a certain point, I very naively made a suggestion: maybe we could be more efficient, just have certain professors could just work with certain stenos ... apparently it started a stampede. Bette, we want Bette! $!^{256}$

The recognition for the contributions of support staff in the late 1960s and early 1970s continued — at the very least, for those doing the senior administrative work. For example, Professor David Coll and his wife Margaret Coll still speak highly of the support staff in the engineering faculty, particularly the former faculty secretary Goldie Wilkinson.

Oh we had excellent relationships with them ... our department was blessed with, still is, with superb support staff ... They were always a part of our lives ... so they were treated as colleagues in Engineering ... especially Goldie ... [she was one of the] three original secretaries who formed a lot of the culture of Carleton. ${ }^{257}$

${ }^{255}$ The Willis Business College is a local private college founded in Ottawa in the late $19^{\text {th }}$ century. It still offers post-secondary training today. http://www.williscollege.com/about_willis_history.php, accessed November 21, 2013.

${ }^{256}$ B. Smith, oral history.

${ }^{257}$ D. and M. Coll, oral history. 
While these staff members were respected, the boundaries between their authority and that of faculty or senior university administrators were nonetheless clearly drawn.

Professor Blair Neatby describes a division of labour at Carleton during the 1960s and early 1970 s that is clearly gendered.

The role of women is, in the administration of the university, is very important in terms of getting the routine things done. But I don't think very many women were so important in making decisions about whether you needed ... to expand some other field of interest ... I think that was men who did that. ${ }^{258}$

And there was yet another gulf between the senior female administrators and those employees who reported to them. The working environment for lower-level support staff was generally more regulated and the physical conditions could be "rough," particularly during the on-going construction that accompanied expansion between 1958 and 1972.

Finn was a leader in the support staff certification drive and, although unique, in some respects her experiences are representative of those of union supporters in the administrative support category. She had finished Grade 13 in 1966, where she had been in the academic stream at high school but was always "grateful that I took typing and bookkeeping." She worked first for "Prudential in Toronto and then for Ian Martin Engineering Associates in Ottawa" before accepting a position as a telephone operator at Carleton in the general services department in $1967 .{ }^{259}$ Her starting salary of $\$ 3,000$ at the university was "not great" but she took the job because one of her benefits was the "free tuition," which was valuable both for herself and her husband, who was a Carleton student. ${ }^{260}$ She quickly learned that not only was her salary low but that her working conditions were not ideal.

\footnotetext{
${ }^{258}$ B. Neatby, oral history.

${ }^{259}$ P. Finn, e-mail to the author, November 18, 2013; P. Finn, oral history.

${ }^{260}$ Ibid.
} 
It was a shift job so [the phone line] was kept open until 10 o'clock at night. [The office] was situated in the basement at the library ... The basement of the library was horrible. It was freezing cold, there were sewer fish in the carpets. And, very crowded, very dull, the windows were all up and behind you. Norm Fenn, the dean of students, his dog used to come and stand in the entrance to the office and bare its teeth at us. It was a quite unattractive German Shepherd who didn't like people except Norm. It actually bit somebody on the campus. I got the call. ${ }^{261}$

Like many women working in offices across Canada, Finn found the workplace restrictive, training inadequate and the system for awarding compensation, including salaries and raises, arbitrary.

It was pretty regimented ... Women had to wear skirts, I couldn't wear slacks [although] eventually we were allowed to wear pantsuits ... and there was no orientation, very little training. We were just sort of thrown in [and] your training manual was a telephone book ... That's it ... you were just supposed to pick it up as you went along. So, you found your way around the buildings by yourself. You found your way through the tunnels by yourself ... you were annually assessed on your performance and then you were just given a raise, there was no discussion about it, it just happened. ${ }^{262}$

By the early 1970s, she had transferred to the purchasing department, which was also originally located in the library basement but eventually relocated to the newly finished administration building. She enjoyed the move, in part because "you didn't have to wear your coat, it was clean, it was new, it was very nice." ${ }^{263}$ In addition, she liked her position as an expeditor in which she was "basically chasing up the orders and seeing where they were and if they had shown up." This work was more interesting than answering and transferring telephone calls, as she was required to order "many exotic things" or track down unusual items such as the observatory that "turned out to be on a train somewhere that got shunted." She also had the opportunity for advancement and

${ }^{261}$ Ibid. As Finn points, out construction was ongoing on campus during this period- "there was mud everywhere" - and few buildings were complete. As a result, "Lots of people were in the [library] basement. All services was in the basement, and I was in general services to start, and then I was in purchasing next door, stationery storage was in the basement, [the] Registrar's Office was in the basement, [as was the ] high school liaison."

${ }^{262}$ Ibid.

${ }^{263}$ Ibid. 
was promoted from expeditor to assistant buyer and eventually active buyer before

leaving the department to become the first executive director of the newly certified

CUASA in 1976.

Finn enjoyed, and excelled at, her work but was very conscious of the gendered

nature of her workplace that eventually limited her career options at Carleton-but not

before she was encouraged to think that she could advance further within the department.

There were certain jobs you could move into [but although] there was one woman buyer, all the others were men. The one woman buyer bought stationery stuff ... it was okay to buy the pens and pencils and so on but you couldn't buy the scientific equipment and the drugs and the hardware and the things that the boys in blue needed, in maintenance control. ${ }^{264}$

[Nonetheless] I got to be an assistant buyer, and then my buyer left, and so I was asked to step in and be the acting buyer. So I did that and ... I was told to stop taking degree courses and take purchasing management courses and this would help me get ahead in purchasing, so I took the major course and came first in the ... greater Ottawa area, which included Cornwall and around there. ${ }^{265}$

Despite her efforts and accomplishments, however, she unequivocally hit the "invisible barrier for women" and had an experience shared by many women, including Grace Hartman, the first female president of CUPE. While Finn was qualified as a purchaser, her manager assigned her to train men hired to do this work. ${ }^{266}$ Not only did she dislike this practice, she also objected when men with fewer qualifications than her earned higher salaries. In one particular case, Finn handled the situation in a manner that was true to her willingness to "get into trouble.",267

264 Ibid.

265 Ibid.

${ }^{266}$ Ibid. Crean, Grace Hartman, 48-49. Hartman worked at the North York, Ontario planning office in the early 1960s. Apparently she had been taking on more responsibility in addition to taking more training. When a job was posted in her department that explicitly "asked for a man" she applied and was turned down. She was then eventually asked to train the young man chosen for the position. According to Crean, Hartman believed that the union as "the only practical instrument for helping women overcome this barrier of discrimination - in pay as well as status."

${ }^{267}$ P. Finn, oral history. 
I had been the expediter and so we hired a ... nice young man, Danny Buisson, French-Canadian, to do that job ... he knew very little English and so I used to have to help him with his English and ... [to] write out the necessary forms and so on ... [He] got married, had a couple of children, and then I find out he's making more than I am. Now, he's got maybe Grade 12, five years' experience [and] I've got some university at that point, and ... eight or nine years experience ... So I went in to my boss, Mr. Dalton, ... stormed in [in fact] and said, "How come Danny's making more than I am?" and I got told "Well, he has a family to support." And I said, "That's funny, I didn't know about this family supplement when I was supporting my husband at university here ... I don't like this ... I work here very hard and I constantly get these, "You're the only promotable person in the department", so why is he making more than me?" And I couldn't get anything other than "He's a male, and he has family." So I said, "It seems to me, you have to have the two P's to get around here." And he said, "What's that?" And I said, "A pipe and a penis." And I slammed the door on the way out. ${ }^{268}$

These enshrined ideas about women's and men's work were not unique to the management practices in purchasing department and inequitable salaries were not the only form of discrimination that female support staff encountered — benefits could be denied. Finn still seems irritated by the fact that, in 1969 , the university policy was that married women were ineligible for coverage under the Ontario provincial medical insurance plan. That year, employees received notice that university would pay $50 \%$ of the premium for designated employees only—married men as well as single women and men - and Finn did not hesitate to confront a personnel officer directly about this policy.

So I ... said to Laurie Cox, "I work here just as hard as everybody else, why am I not being covered this?" "Well, you're expected to go in with your husband." "Well, that's fine," I said, "but my husband works for the government and they're not paying anything" ... She said, "Well I need you to sign this form ... So that we can exempt you." I picked up the form, I ripped it up, threw it on the desk ... And she said, "Well I guess we'll have to cover, we have no signed form. ${ }^{269}$

The personnel department appears to have been a source of particular frustration for Finn — in part because, through their policies and attitudes, the women running that

\footnotetext{
${ }^{268}$ Ibid.

${ }^{269}$ Ibid.
} 
department seemed to reinforce the gendered occupational hierarchy at the university and the double standards that seemed to be applied to women on campus.

The personnel officer [called] ... a series of [luncheon] meetings ... [in] '73 ... so a certain number of us were invited to each one. I went and she was talking about how Carleton was going to develop and ... and the new classification system, there were always new classification systems. And so she drew this one on the board [and said], "Oh I shouldn't be telling you girls about this yet,"-we were girls - but she proceeded to draw it on the board and it was Clerk 1, Clerk 2, Clerk 3, Clerk 4, and Secretary 1 and eventually, if you worked really hard, your ultimate goal was secretary to the president. And I started to crack up, got quite hysterical. And I said to her, "Well, what if we don't want to be secretary to the president, what if we want your job?" Well that was the end of the meeting, we were all dismissed, and she didn't have any more of them.

There was no thought ... that women would want to do more than to be a clerk or a secretary because they were just working to supplement their husband's incomes. And Ruth [Deacon, the head of the personnel department], had, of course, just been a secretary when she was hired, as was Laurie Cox and all the other gals. And so as Carleton grew, they took on more and more responsibilities. They had no training, they just grew with the job ... it never occurred to them that we might want to be ... director of purchasing or anything else. Those were men's jobs. And we hired a lot of ex-military in those days, military men who'd retired. Several of my bosses were military... Well you could get them cheap because they had pensions. ${ }^{270}$

Male non-academic staff undoubtedly had work-related frustrations during the latter half of the 1960s and the early 1970s. CUPE 910 was formed in $1964^{271}$ and by 1975 , the employee turnover rate had reached $32 \%$ and apparently had been steadily increasing for some time, reflecting perhaps a widespread dissatisfaction with working conditions. ${ }^{272}$ But if the technical staff were particularly unhappy or a significant proportion of those leaving the university for better jobs elsewhere, there is no published evidence of their dissatisfaction in the period prior to 1973 . They did, however, become involved with the new support staff association that was formed in 1973 and would be

\footnotetext{
${ }^{270}$ Ibid.

${ }^{271}$ T. Cristiano, e-mail to the author.

272 "Salaries and Benefits Report," the What? 2, no 1 (n.d.): 3, FN 13, Chapter 1.
} 
certified in 1976 as the support staff union. These men worked mainly in the science labs and were amongst the early initiators of collective action. ${ }^{273}$ As a group, they were apparently very aware of the low level of their wages relative to that of their peers in the federal government and willing to support an association that would advocate for salary increases. ${ }^{274}$

In mid-November 1972, members of the existing Carleton University Staff Association (CUSA) met to welcome their new slate of executives and attend to regular business. ${ }^{275}$ CUSA, the association formed in the mid-1960s to which Margaret McEown belonged, seems to have been a very active as evidenced by the "close to 300 members" and the variety of committees reporting that day (workshop, social, publicity, membership and financial and staff relations). ${ }^{276}$ Nonetheless, for support staff employees who wanted to negotiate terms and conditions of work, CUSA was strictly a social club that they were not interested in joining because it "just muddled along doing whatever it did." ${ }^{, 277}$ Instead, they wanted an association that could "lobby for some sort of recognition for the management, we could put in salary briefs, and we could talk about benefits, and going on summer hours, and things like that. ${ }^{278}$ Given that Finn was "outspoken and forthright," she already had individual employees "bringing their complaints to me" and so she understood that others shared her frustrations. But she had also realized that "just going cap in hand and begging wasn't getting anywhere, that you had to level the playing

${ }^{273}$ B. Smith, oral history. See also P. Finn, oral history.

${ }^{274}$ See for example, "A Committee is: Report from the Salaries and Benefits Committee," the What? 1, no. 4, (n.d.), 3, FN 13, Chapter 1.

275 "CUSA Elects New Executive," This Week Times Two 4, no. 10 (Tuesday, November 14, 1972),

FN 3, Chapter 2.

${ }^{276}$ Ibid.

${ }^{277}$ P. Finn, oral history.

${ }^{278}$ Ibid. 
field. ${ }^{279}$ As a result, sometime in either 1972 or early 1973, she helped to found the Carleton University Non-Academic Staff Association (CUNASA) along with other administrative staff and chemistry technicians. ${ }^{280}$ Then on July 19, 1973, it was announced in This Week Times Two, the campus newsletter, that CUSA and CUNASA had "merged to form the Carleton University Support Staff Association."281

Support staff employees at Carleton were not the only administrative and technical workers to organize in the university sector at this time-either in Ontario, Canada or the United States - and one university support staff union actually went on strike in the early 1970s. ${ }^{282}$ The University of Saskatchewan Employees' Union (USEU) appears to be the oldest English Canadian union in the sector and formed by eight power plant workers after the Saskatchewan government introduced its Trade Union Act in $1944 .{ }^{283}$ Organized under the auspices of the Canadian Congress of Labour, it was not a "friendly employee association" but a "real trade union" and encountered significant institutional roadblocks before certifying in 1945, including resistance from some workers who wanted the existing staff association to remain a "social club." ${ }^{284}$ This union has strong blue-collar roots and initially its members included a wide range of employees doing manual work

${ }^{279}$ Ibid.

280 "New Staff Association Formed on Campus," This Week Times Two 5, no. 15 (July 19, 1973), FN 3, Chapter 2.

${ }^{281}$ Ibid.

${ }^{282}$ It has been difficult to find information about other academic support staff unions. As a student, I worked part-time at the Simon Fraser University Library from 1977-1982 and was unionized. According to John Bannister, the union then was the Association of University and Collage Employees, Local 2 (AUCE 2), which certified in 1974. In 1992 the members of AUCE 2 voted to join the Canadian Union of Public Employees becoming CUPE Local 3338. Bannister is the current business agent for CUPE Local 3338. In addition, there is mention in an early issue of the What? of a visit from a representative of the University of Alberta staff association. There is no indication, however, as to whether that association was unionized. "Announcements," the What? 1, no. 2 (June 1974): 2, FN 13, Chapter 1. In addition, the University of Toronto CUPE Local 1230 became the bargaining unit for full-time support staff at the University of Toronto Library. Blackburn, Evolution of the Heart, 304.

${ }^{283}$ Makahonuk, "'In Union is Strength'," 31.

${ }^{284}$ Ibid., 32 
such as farm workers, waitresses, machinists and truck drivers in addition to the workers in the power plant. Even from the beginning, however, white-collar clerical workers were included in the bargaining unit and, by the 1970s, union members in this employee category included cashiers, stenos and library assistants. ${ }^{285}$ USEU members went on strike in 1974 and improved wages and benefits during a period of high inflation were the key issues. ${ }^{286}$ Workers in Ontario English universities were slow to follow suit but by 1973 the "first wave" was beginning to build: the University of Toronto Staff Association (1971), which received voluntary recognition from the university's Board of Governors ${ }^{287}$ the University of Toronto library staff (1973) ${ }^{288}$; Guelph University (1974); and York University (1975). ${ }^{289}$ In addition, employees at the University of Western Ontario, McMaster University and the University of Waterloo all had non-unionized staff associations that were active to some extent on work-related issues. ${ }^{290}$

In the United States, similar organizing campaigns were underway. Library staff in California working for public colleges and the University of California, Berkeley joined the American Federation of State, County and Municipal Employees (1972); ${ }^{291}$ administrative and technical formed support staff unions at the University of Rhode Island (1974); ${ }^{292}$ and between 1973 and 1974 District 65 was successful in organizing

${ }^{285}$ Ibid., 35.

${ }^{286}$ Ibid., 34.

${ }^{287}$ Ross, The Short Road Down. 112. This association was formally recognized as the support staff bargaining agent by the university administration in 1971 but is not legally certified.

${ }^{288}$ Ibid., 113 This union certified as a CUPE local and went on strike in 1975.

${ }^{289}$ Mudge, "Bargaining Unit Composition," 19.

${ }^{290}$ A Meeting of Universities of Ontario at Queen's University, June 8 \& 9, the What? 1, no. 2 (June 1974): 5, FN 13, Chapter 1.

${ }^{291}$ Flanagan, "Sleeping Giant Awakes," 492-94. The mandate of the American Federation of State, County and Municipal Employees (AFSCME) appears to be similar in scope to CUPE and has unionized other university support staff workers, such as those at Yale University. See Anderson, "On Strike Against Yale University"; Weber, "Support Staff Unions in Academic and Public Libraries," 65-86.

${ }^{292}$ Sansbury, "Now, What's the Matter With You Girls?"," 67. 
clerical staff at colleges affiliated with Columbia University. ${ }^{293}$ And why not? A survey of office staff in higher education in the United States released in March 1980 by Working Women, National Association of Office Workers revealed that "campus clericals are woefully underpaid and treated not better, often worse, by non-profit institutions of higher learning than clerical employees in private, for-profit institutions. ${ }^{, 294}$ In sectors other than Canadian municipalities (where CUPE representatives were aggressively organizing), clerical employees in Canada were also dissatisfied and predisposed to fight for collective bargaining rights. For example, in 1976 female employees at the Victory Square branch of the Canadian Imperial Bank of Commerce in Vancouver attempted to form The United Bank Workers, a local of SORWUC, the Service, Office and Retail Workers Union of Canada. This union drive was prompted by poor working conditions that included poor wages-“"a] full-time stenographer made so little money that her salary was subsidized by welfare"295 —unpaid overtime and arbitrary decision-making by management. In principle these workers

${ }^{293}$ Hurd, "Learning from Clerical Unions," 34. According to Hurd, "At the time District 65 was an independent union, formerly known as the Distributive Workers. In 1981, District 65 merged with the United Automobile Workers." 33.

${ }^{294}$ Working Women, National Association of Office Workers, Becoming a Priority: The Status of University and College Office Staff, National Survey and Analysis of Office Employment in Higher Education, (Cleveland, Boston, Washington, D.C.: National Association of Office Workers, 1980), 1. The survey was conducted from November 1978 to December 1979; it was distributed to 18,000 participants working at universities and colleges (private and public) across the United States. It had a response rate of $12.6 \%$. According to Joy B. Reeves and Ray Darville, as of 1986 this study was only one produced on clerical workers in an academic setting. Joy B. Reeves and Ray Darville, "Female Clerical Workers in Academic Settings: An Empirical Test of the Gender Model," Sociological Inquiry 56, no. 1 (January 1986):105-24.

${ }^{295}$ The Bank Book Collective, An Account to Settle. The Story of the United Bank Workers (SORWUC) (Vancouver: Press Gang Publishers, 1979), 19. Women were also becoming more active in federal public sector unions such as the Canadian Union of Postal Workers. See for example, Julie White, Mail \& Female. 
agreed with Sylvia Gruda and Pat Finn: "it became a simple matter of wrong and right." 296

The next three years proved busy for active CUSSA members. Association founders hoped to provide "a unified voice for all non-academic staff" in order to "secure the most favourable terms of employment and working conditions." ${ }^{297}$ Guided by a new constitution, they opened an office in the Herzberg building as soon as possible ${ }^{298}$ and operationalized a governance structure consisting of an elected ${ }^{299}$ council that included a president, vice-presidents, a secretary and representatives from designated "zones" across the campus. ${ }^{300}$ As President Paul Sussman outlined in the second issue of the association newsletter, The What?, in the first year of operation (1973 to 1974) volunteers set up committees with written terms of reference, defined clear eligibility criteria, developed "formal lines of communication" as well as grievance procedures and a database for salary information. ${ }^{301}$ This institutional framework was important to establish if CUSSA representatives were to have a platform from which to meet the immediate challenges of

${ }^{296}$ Ibid., 1-19.

297 "New Staff Association Formed On Campus," This Week Times Two, FN 3, Chapter 2.

298 "CUASA Election," This Week Times Two, Friday 9, no. 2 (May 3, 1974), FN 3, Chapter 2. The office address was Room 424 Herzberg Laboratories for Physics.

${ }^{299}$ Ibid.

${ }^{300}$ Various issues of the What? (June 1974 to Spring 1975), FN 13, Chapter 1. The author has possession of newsletters 1, no 2. (June 1974) to 3, no. 1 (Spring 1975) but issues are missing for all years, including the inaugural issue of the newsletter. The zone structure is described by Membership Committee Chair Fern Small in her column in the What? 1, no. 3: 4. The current executive is listed in the same issue on page 7 and includes the president, two vice-presidents (internal and external), executive secretary, recording secretary, treasurer and five committees: grievance, membership, social, publicity, and salaries and benefits.

${ }^{301}$ Paul Sussman, "President's Message," The What? 1, no. 2, FN 13. Chapter 1. When he resigned as president in late 1974, Sussman was described in the What? as "the first president of CUSSA and one of the figures in its inception." "Our President Resigns," the What? 1, no. 4: 7, FN 13, Chapter 1. 
mobilizing solidarity amongst support staff and "harmoniously" gaining the recognition from university administrators as the official bargaining agents of support staff. ${ }^{302}$

Increasing membership was a top priority. In the first year, "432 of the 920 odd possible" staff eligible had joined CUSSA, a number that fell short of the 55\% (or 598) members that CUSSA would need if the decision was ever made to file an application with the Ontario Labour Relations Board (OLRB). ${ }^{303}$ One principle strategy for engaging support employees was to keep fees low. ${ }^{304}$ Another tactic was to gather and disseminate compensation information, and in particular comparative data on salaries and benefits in other universities as well as Ottawa-are employers, particularly the federal government. Comparisons to salary levels of Government of Canada employees were common in the newsletter but, in addition, information regarding remuneration at other Ontario universities also began to appear. ${ }^{305}$ The publication of this latter data was made possible by the participation of CUSSA representatives in the formation and operation of the Confederation of Ontario University Support Staff (COUSA) in June $1974 .^{306}$

The new confederation was designed as an advocacy group for provincial support staff organizations and its members associations (that collectively represented 4,500 307 support staff in Ontario) would not only share information on a range of topics related to

302 "New Staff Association Formed on Campus," This Week Times Two 6, no. 15 (Thursday, July 19, 1973), FN 3, Chapter 2.

${ }^{303} \mathrm{FN} \mathrm{4}$, Chapter 2 of this thesis for full explanation the requirements for certification and representation vote.

${ }^{304}$ Typically a membership application was included on the last page of the newsletter and the fees were prorated according to salary. Anyone earning $\$ 4,000$ or less paid a monthly deduction of $\$ .50$. the What? 1, no. 3 (n.d.): 8 , FN 13, Chapter 1.

${ }^{305}$ I cannot determine where this data was obtained by CUSSA.

306 "Support Staff Confederation," This Week Times Two (Thursday, June 13, 1974): 1, FN 3, Chapter 2. The inaugural meeting was held at Queen's University on June 8 and 9.

${ }^{307}$ Shawn Haley, “COUSA Becomes a Reality," the What? 1, no. 4 (n.d.): 1, FN 13, Chapter 1. 
employment but also "act as a united front" with the Ontario government. ${ }^{308}$ Carleton participants regularly attended COUSA meetings and the newsletter featured updates on the compensation packages in place at member institutions such as the University of Waterloo, the University of Toronto and York University. CUSSA representatives also worked to actively on campus to resolve grievances. Shawn Haley, the first acting grievance committee chair, was confident that he would be able to work with university officials to resolve the "complaints about supervisors, working conditions, et. al."-but members had to submit their grievances in writing. ${ }^{309}$ In addition, CUSSA council members were careful not to neglect the social aspect of solidarity building. For example, on the front page of one of the first issues of the newsletter was a checklist of social activities for staff to complete that included twenty-nine possibilities ranging from badminton and billiards to painting and musical groups. Corn boils were a common occurrence, staff could even attend "Happy Hour" at the Faculty Club and there was an active bowling league. ${ }^{310}$

In late 1974, Paul Sussman resigned as president and June Landsberg was appointed as the acting chairperson before subsequently being elected president prior to the end of the year. ${ }^{311}$ Landsberg was working in the Instructional Aids Department (Office of the Vice-President [Academic]) and was a zone representative as well as a member of the CUSSA Salaries and Benefits Committee. ${ }^{312}$ It is unclear why she was chosen to succeed Sussman — perhaps she volunteered or was asked to take over.

308 Ibid.

${ }^{309}$ Shawn Haley, “Grievances!!!” the What? 1, no. 2 (June 1974): 4, FN 13, Chapter 1.

310 the What? 1, no. 2 (June 1974) 1-2.

311 “Our President Resigns," the What? 1, no. 4, (n.d.): 7, FN 13, Chapter 1. The date is uncertain because quite a few issues of the newsletter were printed without complete dates.

312 "A Committee Is," the What, 3, FN 13, Chapter 1. 
Regardless, she was seen as a well-organized person and "once we decided where we were going, she was really good." 313 She certainly made a lasting impression on Sylvia Gruda.

June Landsberg ... I just thought the world of her ... we had a good time ... [One time] we all drove to Toronto to hear about labour and ... and I was there and I drank scotch with them, and I was just $20-21 \ldots$ and they were maybe in their late, early $30 \mathrm{~s} . .$. and it was sort of the first time I felt that I had grown up. And I ended up serving on the executive at that time as Vice President Internal and June was a fabulous leader and basically she knew how to delegate and ... and I guess I grew. 314

Landsberg took over leadership of CUSSA at a time when the efforts of volunteers, and the compensation committee, in particular, seemed to have stalled due to resistance from university administrators. The committee's first written benefits brief to senior university managers in January of 1974 met with a cautious response from Doug Brombal, the administrative services director, that was unsatisfactory to committee members and an open meeting held the following October with President Oliver, VicePresident Administration and Bursar Ab Larose and Brombal was equally frustrating: "much was said to little advantage. ${ }^{315}$ In particular, administrators seemed unready to recognize CUSSA as the support staff bargaining agent, nor was a hoped-for cost-ofliving increase to be forthcoming. The frustration of C.J. Hidson, the chair of the CUSSA committee for salaries and benefits, was clear in each successive report she published in the What? and the introduction to the committee's final salaries and benefits brief for 1974 was a straightforward articulation of the CUSSA official position:

Some of our discontent is based on:

\footnotetext{
${ }^{313}$ P. Finn, oral history.

${ }^{314}$ S. Gruda, oral history.

315 "That Familiar Refrain," the What? (n.d.): 1, 1 no. 4, (n.d.): 6, FN 13, Chapter 1.
} 
1. An assumption that we are not receiving a share of the salary budget in accord with our contribution to the function of the university.

2. A knowledge that for the work we do, other employers in the Ottawa area are paid higher salaries.

3. A feeling of discrimination on the part of senior administration i.e. a master-servant relationship.

4. An opinion shared by all support staff that more government subsidy is required.

5. A knowledge of inequalities within our support staff classifications.

6. Inadequate fringe benefits.

Support staff must participate in the development of all changes and improvements directly relating to our role in the University community. ${ }^{316}$

Other council members, such as outgoing Vice-President Internal, Robert G. Perron, cautioned support staff to recognize that 1974 had been a good year for CUSSA and that employees should prepare for salary cuts, not increases, given the university's current financial hardships. ${ }^{317}$ At least some employees must have shared Hidson's irritation, however, because membership in CUSSA continued to mount slowly and, in fact, had reached 505 in early January $1975 .^{318}$ That month, President Oliver approved meetings between the CUSSA council members and senior managers that suggested an improvement in "the relationship between support staff and administration" 319 and some positive salary adjustments were also announced that month. However, within two months, whatever consolation support staff might have taken from higher wages was replaced by serious concerns triggered by two key events: support staff layoffs and the certification of CUASA as the bargaining agent for faculty members.

${ }^{316}$ Salary and Benefits Committee, Carleton University Support Staff Association, Brief Regarding Salaries and Benefits of the Carleton University Non-Academic Support Staff. For Submission to the Board of Governors and Carleton University Administration (December 1974), 1, Carleton University Corporate Archives, CUSSA-001-8, (Part 2), Miscellaneous News and press releases, Carleton University Corporate Archives, Ottawa, Ontario.

${ }^{317}$ Robert G. Perron, "Internal Report," the What? 2, no. 1 (n.d.): 4-5, FN 13, Chapter 2.

318 "Zone Meeting," the What? 2, no. 1 (n.d.): 10, FN 13, Chapter 1.

319 "Certification-Yes or No?," the What? 2, no. 3 (July/August 1975): 1, FN 13, Chapter 1. 
In March 1975 two Carleton technicians received verbal notices of lay off. ${ }^{320}$ As reported in the student newspaper The Charlatan, on Friday, March 14, 1975, Stephen Szick was informed that his job as a physics lab technician would be eliminated on June 30, 1975. The following Monday, March 17, geography technician Campbell Kidston was also told that his job would no longer exist as of the end of June. ${ }^{321}$ Both men were considered long-term university employees: apparently Szick had been working at Carleton for fifteen years while Kidston had been employed on campus for five years. The news of the job losses undoubtedly travelled across campus by word-of-mouth but the CUSSA executive also made a formal report to members on (or close to) March 24, 1975 in a bulletin entitled Facts and Statements to Think about Concerning Discussions on Certification. ${ }^{322}$ Support staff had been aware for some time that "service levels" were being cut and close to sixty support staff jobs had been lost recently but these losses had been compensated for by the high turnover rate-so presumably seemed less threatening. ${ }^{323}$ According to Pat Finn, the lay-offs were different and "a huge mobilizing factor ... Carleton had grown steadily so that was a big shock to everybody." ${ }^{, 324}$ Sylvia Gruda concurs, recalling that the two apparently permanent redundancies were frightening to support staff employees. ${ }^{325}$

There obviously was some kind of funding problem because they were cutting back staff ... despite seniority. So somebody ... who had maybe been there 18 years got laid off versus somebody who had just started [the] reason being that that person probably made a good salary and ... perhaps this person did have

320 “Who's Next? Support staff workers laid off," The Charlatan 4, no. 28 (Friday, March 21, 1975): 1, FN 373, Chapter 2.

321 Ibid.

${ }^{322}$ Carleton University Support Staff Association, Facts and Statements to Think about Concerning Discussions on Certification, (n.d.), 1, Carleton University Support Staff Association Fonds, CUSSA-001-8, Miscellaneous News and press releases, Carleton University Corporate Archives, Ottawa, Ontario.

323 Ibid.

${ }^{324}$ S. Gruda, oral history.

${ }^{325}$ P. Finn, Pat Finn and S. Gruda, oral history. 
formal education, could have been an immigrant worker very well educated, but was given the boot because maybe his salary was the one that ... was affecting the budgeting ... So there was sort of no recognition for good work then ... you were just considered to be a widget. ${ }^{326}$

Then professors and librarians voted for the certification of CUASA and staff fears were intensified. Bette Smith's reaction may well have been similar to that of other support staff employees. She believed that administrative and clerical workers would suffer directly from any gains made by the faculty association.

The faculty having unionized, now had a voice and were bargaining with the university who had to listen to them first, because they had already unionized ... we were going to get the leftovers, or ... it was going to be the staff where the deepest cuts would be made ... [we] ... were going to ... pick up the slack and still do the work. ${ }^{327}$

The members of the CUSSA council of representatives were ready to capitalize on this pessimism. On March 6, 1975, even before the staff layoffs were announced, they had passed a motion in support of the association as the legal bargaining agent.

Representatives planned to "make all attempts to gain voluntary recognition" but these efforts failed, they would apply to the OLRB for certification. ${ }^{328}$ Over the next five months, they increased their efforts to sign up the requisite number of members needed for certification, using some of the same organizing tactics that had proven relatively successful since 1973. Finn and other organizers met with support staff in a variety of locations across campus including departments as well as other public spaces at the university. ${ }^{329}$

A lot of us spent time at lunch hours, before work and after work, sitting at desks in foyers in buildings, signing up people, going around and talking, I did a lot of

${ }^{326}$ S. Gruda, oral history.

${ }^{327}$ B. Smith, oral history.

328 “Certification-Yes or No?,” the What? 2., no. 3, (July/August 1975): 2, FN 13, Chapter 1.

${ }^{329}$ P. MacRae, oral history. MacRae remembers that, "we had the campaign when people were going around and signing up everybody in their offices. And we had these little cards ..." 
going around and talking to departments and little groups of people, all over the university. So at one time I knew pretty much everybody who worked there because I'd been talking to them. ${ }^{330}$

The council representatives also began a review of the constitution to correct "loopholes, vagaries [sic] errors and omissions" and to ensure that wording was included to ensure that the association had the right to bargaining collectively on behalf of members, as required by the Labour Relations Act. ${ }^{331}$ And they continued to seek the "consensual agreement" from university administrators Larose and Brombal that would give CUSSA status as the exclusive bargaining agent without the need for the legal approval of the OLRB. ${ }^{332}$ There were acknowledged dangers to voluntary recognition-in particular "being raided by outside unions"-but these concerns proved moot when, on August 7, they reached a "critical juncture. Larose and Brombal (presumably with the approval of the president and Board of Governors) "categorically stated" that "if support staff desired collective bargaining they should follow the proper procedure set out in the Ontario Labour Relations Act." ${ }^{, 33}$ While others may have found this turn of events alarming, Pat

Finn was pleased.

We kept having these meeting[s] where we were told, those of us who were pushing for a union (mainly Sylvia and I) that the management would voluntarily recognize us, we didn't need to do that. So I'd had enough at one point and the president, June Landsberg, just happened to be away. So I dragged Sylvia and the other vice-president ... up to a room and said, "Okay ... we've got to write a letter and ask for voluntary recognition, we're going around in circles here ... so let's just do it." And I got, "Oh well, we can't do that because June's away". ... I said, "June won't care, I mean we're going to get a letter back saying no, so let's get the letter back saying no." So I wrote the letter ... and of course we got the letter back saying no. 334

\footnotetext{
${ }^{330}$ Ibid.

331 "New CUSSA Constitution," the What, 2, no. 2 (July/August 1975): 4, FN 13, Chapter.

332 "Certification-Yes or No?," the What? (July/August 1975).

333 “Critical Juncture," the What? 2, no. 2 (July/August 1975): 10, FN 13, Chapter 1.

${ }^{334}$ P. Finn, oral history
} 
Concluding that the only option open for gaining an "effective voice" was to apply to the OLRB, the council then took several steps in preparation for certification. On August 13, 1975, council voted to hire Carleton student Phyllis MacRae to coordinate the certification drive. ${ }^{335}$ The next day, they held a referendum ballot for CUSSA members requesting approval to make draft changes to the constitution as required by the Ontario Labour Relations Act and, of the 388 members (76\% of total membership) who cast ballots, $90.4 \%$ voted in favour of drafting amendments. ${ }^{336}$ Then, with MacRae's assistance, council prepared for the September 18, 1975 ratification vote on the proposed constitutional revisions. Information sessions took place prior to the meeting and, after the vote was held on September 19, June Landsberg informed Carleton support staff that CUSSA members had ratified the constitutional amendments and that the association representatives would be applying to the OLRB for certification. ${ }^{337}$

CUSSA representatives immediately launched a new membership drive. "Old members" had to reapply while new members would be recruited and everyone would sign a membership card authorizing payroll deduction (probably for dues) plus pay an initiation fee of $\$ 1.00 .{ }^{338}$ In the meantime, a membership kit was distributed that included a copy of MacRae's handout, Certification? Why? that identified key reasons for

\footnotetext{
${ }^{335}$ Carleton University Support Staff Association, "Minutes of Council of Representatives Meeting, August 13, 1975," 2. Carleton University Support Staff Association fonds, CUSSA-002-02, Carleton University Corporate Archives, Ottawa, Ontario. MacRae recalls that "it was probably" Professor Allan Moscovitch, in Carleton's School of Social Work, who suggested her for the position. P. MacRae, oral history.

${ }^{336}$ Carleton University Support Staff Association, untitled notice to CUSSA members announcing the approval for constitutional amendments; Carleton University Support Staff Association, Minutes of the Council of Representatives, August 22, 1975. Carleton University Support Staff Association fonds, CUSSA-002-02, Carleton University Corporate Archives, Ottawa, Ontario.

${ }^{337}$ June Landsberg, memo to Carleton University Support Staff, September 19, 1975, Carleton University Support Staff Association fonds, CUSSA-001-8 (Part 1), Miscellaneous News and press releases, Carleton University Corporate Archives, Ottawa, Ontario. I cannot find any record of the voter turnout or percentage of votes in favour of or against the constitutional changes.

${ }^{338}$ Ibid.
} 
supporting certification including protection from budget cuts; bargaining rights; outside assistance to resolve disputes; legal recourse to enforce a contract; and "equal pay for work of equal value." ${ }^{339}$ Forty-one people then volunteered to be signing officers including Sylvia Gruda and Jellowe Clarke in the library, Pat Finn from the administration building, and Ian Babcock in the Steacie Chemistry Building. ${ }^{340}$ The deadline for the membership drive was October 6, 1975 and by October 8, 1975, MacRae reported that not only had she been meeting with employees across campus to discuss further the certification drive, she was also confident that the CUSSA application would be ready to send to the OLRB the following week. ${ }^{341}$

The application was actually filed on November 4 and the OLRB then set the CUSSA hearings for December 18. ${ }^{342}$ The application process should have been relatively smooth but became fraught, in part because as Phyllis MacRae confesses with chagrin, she "screwed up with the cards."

The cards were in two parts ... [and] as I recall ... they had the same information: the person's name, address, and the fact that they paid ... a joining fee or something ... so there was a lot of stress about getting all those cards and making sure we had the right numbers and because, if you had ... below a certain number, there would have to be a vote, but above a certain number you didn't have to. You could be certified without a vote. So ... we got sort of by without a vote. We did have sufficient numbers ... that was a very exciting period. ${ }^{344}$

${ }^{339}$ Phyllis MacRae, "Certification? Why?,” (n.d.), Carleton University Support Staff Association fonds, CUSSA-001-8, Miscellaneous News and press releases, Carleton University Corporate Archives, Ottawa, Ontario.

${ }^{340}$ Carleton University Support Staff Association, "Signing Officers," Carleton University Support Staff Association fonds, CUSSA-001-8, Miscellaneous News and press releases, Carleton University Corporate Archives, Ottawa, Ontario.

${ }^{341}$ Carleton University Support Staff Association, "Minutes of Council of Representatives Meeting," CR-51, Wednesday, October 15, 1975, 2, Carleton University Support Staff Association fonds, CUSSA002-2, 2; "Minutes of the Council of Representative," 1973-1975, Carleton University Corporate Archives, Ottawa, Ontario.

342 "What's Next?," the What? 2. no. 2 (December 1975): 1, FN 13, Chapter 1.

${ }^{343}$ P. MacRae, oral history.

344 Ibid. 
In fact, this mistake resulted in the delay of the hearings by a month. When the CUSSA delegation arrived at the hearings in Toronto, the OLRB "refused" the cards on the technical grounds that they had arrived past the legal deadline. A second hearing was set for January 12, 1976 and the OLRB did not require members to resign their membership cards. $^{345}$ In addition, the issue of bargaining unit exclusions seemed to cause some anxiety for support staff. "Green notices" from the OLRB had been posted on campus and staff needed to be reassured that this was a standard procedure and designed to ensure that CUSSA members would "end up with a unit which is suitable for collective bargaining." 346 CUSSA council members had already identified eighty positions for exclusion and eventually agreement was reached to exclude 193 positions from the bargaining unit, including all the senior administrative staff and departmental administrators such as Evelyn Aldridge. ${ }^{347}$ In the meantime, CUSSA had begun to prepare for negotiations by electing its negotiating team and holding a series of fourteen sessions in late November to gather input from support staff on key bargaining issues. ${ }^{348}$ When the council representatives received the final decision from the OLRB on March 11,1976 , they were ready to proceed. The OLRB had granted the association the legal

${ }^{345}$ June Landsberg, Memo to all CUSSA Members, December 19, 1975, Carleton University Support Staff Association fonds, CUSSA-001-8, Miscellaneous News and press releases, Carleton University Corporate Archive, Ottawa, Ontario.

346 "Exclusions," the What? 2, no. 2 (December 1975): 2, FN 13, Chapter 1.

347 June Landsberg, "Exclusions from the Bargaining Unit," February 9, 1976, 1-9, Carleton University Support Staff Association fonds, CUSSA-001-8, Miscellaneous News and press releases, Carleton University Corporate Archives, Ottawa, Ontario. As Landsberg explained in a memo to all CUSSA members on January 20, 1975, the university administrators challenged 330 positions and this number was reduced through negotiations to 147 before the final 193 positions were identified.

${ }^{348}$ Carleton University Support Staff Association, "Information Meetings," (Tuesday, November 18, 1975): 1-3, Carleton University Support Staff Association fonds, CUSSA-001-8, Miscellaneous News and press releases, Carleton University Corporate Archives, Ottawa, Ontario. 
right to bargain on behalf of 656 support staff and members would have the opportunity to discuss "the implications of this" at a general meeting on March $25 .{ }^{349}$

Overcoming Resistance: From “Workers' Plight” to "More Clout”

Part A. Pros and Cons of Collective Action

In the fall of 1975, Phyllis MacRae and CUSSA Executive Board members had a disagreement over a fundamental issue: how to gain the support of the "diehards" amongst support staff who remained opposed to unionization. ${ }^{350}$ MacRae was a secondyear Carleton University social work student when she secured a four-month field placement in August 1975 as the coordinator for the official certification drive. She was convinced that additional support could be achieved by pushing anti-union non-academic staff towards a "trade union consciousness. ${ }^{351}$ However, MacRae remembers that CUSSA president, June Landsberg, and other executive members wanted to take a less "inflammatory" approach. ${ }^{352}$ They believed that certification would be a more compelling option for these employees if justified in terms of their low status relative to other unionized occupational groups on campus, particularly faculty. ${ }^{353}$ Specifically, they preferred to argue at this stage in the campaign that CUSSA members would lack sufficient "clout" if they continued to try and negotiate better terms and conditions of work with the university administration without the legal status as a bargaining unit that other employees already held, particularly academic staff. Without a union, support staff

\footnotetext{
${ }^{349}$ Patricia A. Finn, Chairperson Publicity/Information Services, Carleton University Support Staff Association, "It's Official," March 11, 1976, Carleton University Support Staff Association fonds, CUSSA001-8, Miscellaneous News and press releases, Carleton University Corporate Archives, Ottawa, Ontario.

${ }_{350}^{35}$ Phyllis MacRae, Field Placement Report, May 31, 1976, in the author's possession.

${ }^{351}$ Ibid.

${ }^{352}$ Ibid.

${ }^{353}$ P. MacRae, oral history.
} 
"would be squeezed out." 354 While their opinions conflicted, MacRae and the association leaders understood that to achieve a majority vote in favour of certification, they needed to frame unionization using a "moral grammar" that would be meaningful to support staff. In particular, unionization had to be compatible with support staff identities, experiences and beliefs.

In early 1973, Paul Sussman, the CUSSA president, made an impassioned plea in the What? for support staff to put aside their ideological differences on unions and join the association because administrative and technical support employees were strongly divided on the benefits of unionization. ${ }^{355}$ At least some of those who were anti-union believed that collective bargaining should be avoided because it was inappropriate as well as unnecessary for university support staff employees. Conversely, those in favour of some form of unionization argued publicly, at the very least, that Carleton University support staff needed some formal representation because generally university managers treated them with disrespect. From 1973 to early 1975, organizers attempted to build support for collective bargaining by continually demonstrating, particularly through articles and information in the What?, that this "workers' plight" was real. In the spring of 1975 , more support staff began to join the association, perhaps because they were afraid that, as members of the group with the lowest occupational status and least "clout," they would not achieve any significant work-related gains. In the fall of 1975 the two sides effectively reached a compromise: support staff would not join a large trade union but would support the certification of their own staff association. This option would give

\footnotetext{
354 Ibid.

355 Sussman, “President's Message.” the What? 1, no. 2 (June 1974): 3, FN 13, Chapter 1.
} 
them a legitimate voice with which to negotiate terms and conditions of work and a bargaining agent compatible with their occupational identity.

Unlike the library opponents to unionization, anti-unionists seem to have been relatively silent about collective bargaining during this phase of mobilization and documentary evidence of their ideas and experiences from this period is unavailable. Clearly, however, they influenced the certification drive because membership grew relatively slowly between 1973 and early 1975. Plus, articles and items printed in the What? during this period continually emphasized key issues such as chronically poor wages, suggesting that many support staff remained unconvinced of the need for collective bargaining. However, those with opposing views did not write for the official CUSSA publication or express their disinterest in other official forums. While there is a lack of textual evidence as to the individual reasons for resisting unionization, the oral histories of Margaret McEown, Evelyn Aldridge, Sylvia Gruda, Pat Finn and Ian Babock reveal that at least some opponents (women and men) felt very strongly that unionization was inappropriate for support staff at Carleton. Their recollections are not representative of all those support staff members who resisted collective bargaining but their thoughts and experiences may provide some insights into the ideas that motivated those employees who opposed unionization. Although only tentative patterns can be identified, there do appear to be some potentially significant differences between women and men and between age groups.

Memories of this period reveal that there were Carleton support staff employees who defined unions as organizations designed to protect a specific type of worker. In particular, those of the "lower classes," whom former Carleton staff have described as 
“tradesmen, and mining workers, labourers" or "blue shirts. ${ }^{, 356}$ Looking back, university support staff employees do not label their work during the period of certification as white-collar but they specifically identify "blue shirt" employees as having had jobs that were distinctly different in status from their own. While they might even consider their own work to have been professional in nature, they remember viewing tradesmen, miners and labourers as people who wore "hard hats and boots" to work and had to "clock in and clock out. ${ }^{.357}$ These workers could also face a higher risk of on-the-job injury, perhaps have longer or more variable work hours and wages low enough to ensure that they lived in poverty and had "to depend on their bosses for whatever they got." ${ }^{358}$ Carleton antiunion support staff could acknowledge the "good side" of unions for these other employee groups, who could suffer in a harsh work environment and thus need the protection offered by collective action, but saw no substantive benefit to unionization for themselves. Bette Smith's secretarial position was ultimately included in the bargaining unit but, although her work was considered junior and definitely non-managerial, she did not think that she automatically shared the concerns of "the workers"-in fact, she firmly rejected an invitation to become a Marxist that she received while working on campus.

I also remember having lunch in the little courtyard that's outside the Loeb building ... just sort of sitting in the sun enjoying it. And this young man came up and started talking to me, and of course I'm a young girl, so happy to talk. And it turned out ... he was trying to get me to ... sign up for Marxism and I was thinking, "Well, why would I want to do that? I want a house, I want a good salary, I want all of these wonderful things and property." And he was kind of saying, "No, no, ... you as a worker need to be concerned about the workers of the world." And I thought, "No. I don't. I need to be concerned about myself. ${ }^{359}$

${ }^{356}$ M. McEown, oral history; E. Aldridge, oral history; D. McEown, oral history; Don McEown used the term "blue shirts" rather than blue-collar.

${ }^{357}$ P. Finn, oral history.

${ }^{358}$ M. McEown, oral history; E. Aldridge, oral history.

${ }^{359}$ B. Smith, oral history. 
Based on these and similar beliefs, anti-unionists questioned the idea that working conditions were fundamentally unfair at Carleton. In their experience, higher salaries and benefits were not necessarily needed; effective dispute resolution mechanisms already existed; and individual merit or seniority would contribute to job security. Moreover, unionization entailed costs—-both material and emotional — that were too high to pay and that, even if incurred, might not lead to desired changes in the workplace.

According to Gruda and Finn, the question of adequate compensation at Carleton plagued organizers of the CUSSA campaign as it had the pro-unionists responsible for the union drive in the library despite the fact that it was widely recognized, by staff and university administrators alike, that salaries at Carleton were consistently below those of other employers with similar workforces in the Ottawa area. ${ }^{360}$ Just as Gruda identified these opponents as older, female and married, so too did Finn encounter resistance from a similar cohort outside the library.

In the beginning it was quite hard to get a number of people to agree to go in the union and that began largely because it was female and we had a large number of older wives who were working for "pin money" and they were not on our side ... the money wasn't the huge issue for them. ${ }^{361}$

And Margaret McEown, who was responsible for hiring the administrative support staff in the late 1960s and early 1970s, observes that "there were a goodly number" of "married women" who were working, in particular so that "the children could get free university ... that was a big plus for them. ${ }^{, 362}$ Even when Finn showed individuals a direct salary comparison between their pay rate and that of other equivalent positions, this

\footnotetext{
${ }^{360}$ M. McEown, oral history.

${ }^{361}$ P. Finn, S. Gruda and P. Finn, oral history.

${ }^{362}$ M. McEown, oral history.
} 
information was not enough to sway a belief that salaries levels did not need to change, or that employees should question management practices.

Jean Loates ... the director of awards ... had a degree. I compared her salary to my boss's salary ... who didn't have a degree, and of course he was making more. She was older, she'd been at Carleton longer, she had a degree, and she was making less because she was a woman. She wouldn't let me do anything about it. $^{363}$

While women were perceived as constituting the majority of those fighting unionization on these grounds, it is possible that some men also objected to collective action for the same reason, and in particular, those "ex-military" personnel who apparently were supplementing their pensions with full- (or perhaps part-) time incomes from Carleton. However, no record of their thoughts or feelings is available and this time opponents did not protest vocally - there is no evidence of anti-union handouts or further meetings with senior administrators other than those conducted officially by CUSSA representatives. Perhaps this cohort did not see the need to launch a public counter-attack. A substantive number in fact may still have been the same library employees who successfully forestalled unionization less than two years ago. Given that the early campaign had failed, they might not have seen the need to revitalize their efforts having so effectively argued during that campaign, "we who are writing do not feel ourselves to be down-trodden second class citizens (as the union literature implied) nor do we feel the need for a union to provide us with 'dignity at work'.,364

Satisfaction with salaries might have justified a lack of interest in unionization for some employees but for others, there was also a general appreciation for the quality of overall working conditions and relationships on campus - and again, some were "older"

\footnotetext{
${ }^{363}$ P. Finn, oral history.

364 The Disadvantages of CUPE at MacOdrum Library, (1972), Carleton University Support Staff fonds, CUSSA-001-9, Carleton University Corporate Archives, Ottawa, Ontario.
} 
women. After almost forty years, both Margaret McEown and Evelyn Aldridge are still very much "against unions." ${ }^{" 365}$ They believed that their working conditions were relatively good at Carleton where hours were "straightforward" and people were "well looked after. ${ }^{, 366}$ In particular, mechanisms already existed for resolving grievances and, in particular, employees had the opportunity to speak to a senior administrator or manager on a range of workplace issues. McEown "always found that I could go to someone with authority and discuss a problem and work out a solution. That it wasn't a dead-end street." ${ }^{367}$ Similarly, Aldridge believed that when she complained about an issue, somebody would look into it on her behalf, such as the economics department chair, who helped to resolve an issue regarding a wage increase one year. ${ }^{368}$

When I went into the library, everybody I think was due for a raise. I didn't get one. And when I went over to Economics, the first year I was there and the raises came out ... everybody had gotten $\$ 20 \ldots$... [and] I got $\$ 15$. So Professor Gordon was chairman ... and I thought, "I'm going to see him about it." ... I asked him ... if he felt my work warranted the same as the others. He said, "It certainly does" ... Professor Gordon took it up ... with the dean ... And it was corrected ... If you feel that you're being mistreated and there's someone that you can talk to, you can get some kind of action, if it's warranted. ${ }^{369}$

Both McEown and Aldridge held administrative positions that ultimately were excluded from the CUSSA bargaining unit and it could be argued that their perspectives are somewhat biased by a sense of belonging to the "management" group. However, both had begun at the university in lower-level positions so their ideas could also be informed by these earlier experiences. Moreover, McEown believes more in individualism than collectivism as strategy for ensuring fair treatment at work: "we were protected with our

\footnotetext{
${ }^{365}$ M. McEown, oral history; E. Aldridge, oral history.

${ }^{366}$ Ibid.

${ }^{367}$ Ibid.

${ }^{368}$ M. McEown, oral history; E. Aldridge, oral history.

${ }^{369}$ E. Aldridge, oral history.
} 
own ability to perform the jobs at a good level and there was no reason, whatsoever, to jeopardize what we had to go into a union." 370 Don McEown has also suggested that such faith in individual merit might have been bolstered for both older men and women who were long-term Carleton employees and thus felt safer than more recently hired, younger workers. ${ }^{371}$ These staff members,

didn't feel threatened because ... they had seniority even if there was a union. So they're not gonna get canned. The people who were interested in it were specialists or people working at the sort of just below the management level. And a lot of them were young men or younger people. ${ }^{372}$

If union supporters were convinced that collective action would pay enormous benefits, opponents identified costs that they were reluctant or unwilling to pay to achieve changes in the workplace. Phyllis MacRae recollects that one of the issues that seemed important to employees during the certification drive was a potential increase in union dues. ${ }^{373}$ The CUSSA dues were pro-rated according to salary and the administrative staff at the lower end of the salary scales might pay less than a dollar each month. Organizers met considerable opposition to the option of joining a "real" union such as CUPE because this membership would entail a significant expense to individual members in the form of higher union dues. In fact, when faced with the choice of certifying with CUPE rather than CUSSA, some support staff indicated that they would choose certification because CUSSA dues would be lower: "It was sort of something like instead of having union dues of $\$ 300$ a year we'll have union dues of $\$ 40$ a year." ${ }^{374}$ However, a cut in monthly pay was not perhaps the cost that worried opponents the most. It is possible that an equally

\footnotetext{
${ }^{370}$ D. McEown and M. McEown, oral history.

371 Ibid.

372 Ibid.

${ }^{373}$ P. MacRae, oral history.

374 Ibid.
} 
strong motive for opposing unionization was the perception that there were real risks to collective action including heavy economic loss due to a strike and the relationships between managers and subordinates that would be antagonistic rather than harmonious. ${ }^{375}$ Aldridge believed that in a unionized environment, "Somebody's upset and they mention it to somebody else and they catch onto it and before you know it, you have a problem. ${ }^{, 376}$ If discontent led to job action, employees who went on strike always lost financially_essentially a union just caused turmoil.

Finally, sometimes support staff feared that unions might not effectively deliver on the promised protection — particularly large national unions like CUPE—or protect those who did not justify this support. Lothar Klimpel was a supervisor in the chemistry lab and CUSSA's Vice-President External in 1974. Although he was initially actively involved in the staff association, it appears that he was also against unionization if it meant joining a large "external" union such as CUPE and stated publicly in an August 1974 issue of the What? that such "external affiliation" was "completely unacceptable." ${ }^{377}$ He preferred to gain voluntary recognition of the association by university managers because outside unions had inherent dangers. These included discrimination against supervisory staff who needed protection but would be excluded from the bargaining unit, the possibility of multiple small bargaining units, negotiated contracts with salary increases which ultimately disadvantaged non-unionized staff on campus and the potential lack of financial backing from the national union during contract negotiations. ${ }^{378}$ Klimpel did not, however, mention an additional threat that

\footnotetext{
375 Ibid.

${ }^{376}$ E. Aldridge, oral history.

${ }^{377}$ Lothar Klimpel, “The Province," the What? 1, no. 3, (n.d.): 5, FN 13, Chapter 1.

378 Ibid.
} 
concerned other employees: unions would defend even those individual employees who abused such protection. Bette Smith developed this view first-hand by witnessing her father's experience at in the City of Ottawa filtration plant. Her dad was not "fond" of unions because he had had to supervise a difficult worker at the plant.

Dad was supposed to be giving him oversight, but ... was finding him to be basically just difficult all the time: lazy, impossible to work with, wasn't doing his job properly ... apparently this person was a union member. And there was very little that he [Dad] could do other than basically take notes and sort of send him letters and ... do that usual going through the union. And to a certain extent, when he died of a heart attack, we kind of blamed that person and the union for making his job as a supervisor pretty well impossible. ${ }^{379}$

Beyond the material reasons for resisting the move towards collective action, there were employees who felt a strong loyalty and gratitude to the university that precluded the risk of a less than congenial relationship with managerial staff. Aldridge still seems annoyed that staff would unionize when they should be grateful for the opportunity to work. Not only had she been desperate for work as a young woman during the Great Depression, she had also worked for a number of employers including the federal government. These experiences led her to believe that Carleton employees should have appreciated their university jobs.

I worked in the government too ... if you were late fifteen minutes, you got [in trouble] ... they were really on strict terms ... Boy, you had to appreciate your job and you had to work for what you got. So that's why I'm against unions ... [they think] ... they're hard done by ... they don't realize how lucky they are to have a job. ${ }^{380}$

As Gruda discovered, Aldridge was not the only opponent with this perspective. When she first started working in the library, Gruda often heard from other employees that,

\footnotetext{
${ }^{379}$ B. Smith, oral history.

${ }^{380}$ Ibid.
} 
"You should be grateful for working at a university, don't complain."381 Likewise, Jean Loates did not want Pat Finn to pursue the issue of salary differential because she believed that "“"Carleton's been good to me, I'm not going to raise a fuss" ... Years after she retired, she told me she really regretted that. She said, "That affected my pension, didn't it Pat?" I said, "Yes of course it did Jean.","382 These stories do not demonstrate conclusively the pre-eminence of any single factor as the cause for anti-union sentiments amongst support staff. However, they do suggest that both material and moral concerns informed the positions of support staff and that there might have been underlying attitudes to work and collective action that were gendered and influenced the resistance of men and women.

The pro-union support staff were much more visible during mobilization than their anti-union colleagues and they clearly believed the current labour practices were insufficient protection against unfair management practices. ${ }^{383}$ Many of their terms and conditions of work were inequitable, and they needed to act collectively in order to participate in the institutional decision-making process and make substantive improvements in the workplace. However, while pro-association support staff members were united in this central belief, they did not always agree on either the job-related issues that needed to be addressed or the type of labour organization they thought most appropriate for their occupational groups. Some of the members of the largely male technical support staff group appear to have been more focused on economic concerns while the mostly female administrative employees were intent on social justice issues such as systemic discrimination. These differences also influenced to some extent

\footnotetext{
${ }^{381}$ S. Gruda, oral history.

${ }^{382}$ P. Finn, oral history.

383 Ibid.
} 
individual support for one of two bargaining options: those who were most interested in improving financial benefits such as salaries appear to have been more willing to accept voluntary recognition but those with an ideological commitment to social justice tended to argue that the staff association had to have "fangs" to provide adequate protection which meant belonging to a union with the legal right to bargain on behalf of its members. As MacRae points out, these employees might not have seen themselves as blue-collar or working class, but they believed themselves to be the organizational "underdogs" who faced systemic discrimination, particularly female employees. ${ }^{384} \mathrm{~A}$ legal bargaining agent was necessary to have a recognized and enforceable "voice."

Carleton technical support workers are consistently portrayed as initially being very supportive of collective action. Bette Smith refers to them as "young Turks"- "the younger men," perhaps impatient, eager for change and just a bit "separate" from everyone else ${ }^{385}$ but "outside the management circle. ${ }^{386}$ Finn recalls that some had made a previous, but unsuccessful, attempt to organize, as had library workers.

I believe the lab technicians got together and tried to form a union of just lab technicians. And they thought it was a go and the management opposed them and said, "No, they're part of the general staff and if they want a union they should unionize the whole general staff" and that just died right there. But they wanted to. ${ }^{387}$

There were certainly young men involved in CUSSA—President Paul Sussman, Grievance Chair Shawn Haley, Gerry Black (an electronics technologist ${ }^{388}$ ) and zone representative Ian Babcock - but there also appear to have been relatively older men who

\footnotetext{
${ }^{384}$ P. MacRae, oral history; S. Gruda, oral history.

${ }^{385}$ B. Smith, oral history.

386 D. McEown, oral history

${ }^{387}$ P. Finn, oral history.

388 "New CUSSA Executive," the What? 2, no. 1 (n.d.): 1, FN 13, Chapter 1.
} 
were active such as Bob Gonyer (an accountant working in the Business Office ${ }^{389}$ ), Hank Koehler and Lothar Klimpel. Despite their presence and commitment to the association, however, these members were largely mute on the topic of collective bargaining, at least in the newsletter. Only Klimpel made any direct reference to unionism in his article on certification and even Sussman, who encouraged solidarity, did not use his "President's Message" column as a platform for urging one form of collective action over another. Moreover, four of the six members of the Salaries and Benefits Committee were women as was the chair, C.D. (Carol) Hidson, even though McRae's memory is that the men were particularly interested in improving compensation levels. For example, Gerry Black wrote the only full-page article for the What? on a single job category, entitled "Wanted ... Electronics Technologist," in which he detailed the high demand for newly graduated electronics technologists that had led to the willingness of private and public sectors employers to pay higher salaries. For Black, the "the real question" was:

Will Carleton University increase the starting salaries to a level near those paid by other employers in the Ottawa area in order to attract these new graduates, and if they do, will they adequately compensate their present employees with the same qualifications for their number of years of experience? ${ }^{390}$

Eventually, however, McRae witnessed a significant schism between the men and the women over the question of unionization that reflected the traditionally gendered ideas about work against which at least some of the women were actively struggling.

Some of the men were quite unhappy ... I don't know if they were just these guys who were in the science labs, because that was one group. There may have been others in other functions ... there was quite a resistance there ... they said, "Fine, go off and form a union, all you women, but we don't want to be part of it because our salaries are going to be pulled down, and this is not going to be in our

\footnotetext{
${ }^{389}$ Ibid.

${ }^{390}$ Gerry Black, "Wanted ... Electronics Technologist," the What? 2, no. 2 (n.d.): 8, FN 13, Chapter 1.
} 
interests." They didn't see that there was any economic interest in being part ... of this larger group. Which is often the case in unions. ${ }^{391}$

Not all the male technicians necessarily were dissatisfied with their working conditions or fully committed to collective action when they became involved in CUSSA — even though they eventually could become stalwart supporters. Ian Babcock had quit one job to take another at Carleton because,

we [Babcock and his wife Donna] were starting a family and I wanted an ongoing position, the benefits ... there was some stability there and ... paid holidays at least and paid sick leave, so it was a pay cut, but it was worth taking because it had a future to it. ${ }^{392}$

Babcock describes himself as "naïve about labour issues" and not very "pro-union" at that time, in part because neither he nor his parents had worked in unionized environments and he had been "apolitical" as a student. ${ }^{393}$ However, during this period more senior departmental members were involved in the staff association, including his supervisor Lothar Klimpel. ${ }^{394}$ Babcock is not completely sure why he joined the staff association except that he was probably encouraged to do so by Klimpel; "I suspect that he would have ... suggested that I should join the support staff association. And unless I saw some strong reason not to, I probably would have.. ${ }^{395}$ Babcock went on to be extremely active in CUPE 2424 (the successor to CUSSA) but, interestingly, does not remember that he also participated in CUSSA as a zone representative in mid-1975 and then as a signing officer later that fall during the certification campaign.

In retrospect, Finn and Gruda view their participation in the founding of CUSSA as an "empowering" opportunity and they were motivated to be involved not only to fight

\footnotetext{
${ }^{391}$ P. MacRae, oral history.

392 I. Babcock, oral history.

393 Ibid.

394 the What? 1, no. 3 (1974), FN 13, Chapter 1.

${ }^{395}$ I. Babcock, oral history.
} 
for social justice but also to establish themselves as individuals with intrinsic rights. For Gruda, her involvement came at a critical point in her life - an experience she believes she shared with Finn, June Landsberg and perhaps other women involved in the union drive.

All of us when we were involved with the union were recently divorced and I think that was a big thing ... because I think we had been with men and we were establishing ourselves as independent women at the time and we had the time also to put into being involved with union work. We spent weekends (Pat interjects: "Nights!"). ${ }^{396}$

They were spurred on by their frustrations with workplace conditions at Carleton but more broadly by their exposure to the feminist movement in Canada, which raised their awareness of the lack of respect they received as women and workers. On the job, employees like Finn had the impression that their work was of no "intrinsic" value and that as individual employees, they were considered to be easily interchangeable.

They got "used to" certain handmaidens being around and doing things for them, but if a new handmaiden came in that was fine too ... they did not see us as having value in terms of experience or different ways of doing things, smarter, better, it was just basically, "Type this letter, well any monkey could do that," right, so you'd just get another one. ${ }^{397}$

Finn and Gruda realize that they shared some of these concerns with "older" women such as Landsberg ("maybe in their ... 30s"), although Finn is not sure that Landsberg was "that big a feminist at the time but her marriage did break up later and I think that changed [things]." ${ }^{398}$ Nor did people have the impression that she was "a strong labour person. ${ }^{„ 399}$ They also were aware that female professors, and particularly Jill Vickers,

\footnotetext{
${ }^{396}$ P. Finn and S. Gruda, oral history.

${ }^{397}$ Ibid.

${ }^{398}$ P. Finn, P. Finn and S. Gruda, oral history.

${ }^{399}$ D. McEown, oral history.
} 
with whom Finn had worked on Carleton's status of women committee, were also working for gender equality on campus.

Of course, union supporters were also influenced to some degree by their earlier experiences and family backgrounds as well as their own personalities. Gruda grew up in a family that had been directly affected by a lack of workplace protection as well as social bias. Her parents emigrated from Poland to Canada after World War II as "DPs" and settled in a "poor part" of Windsor, Ontario. ${ }^{400}$ As a young daughter of "new Canadians" she witnessed the "struggles of the working class" first-hand such as strikes and layoffs. Her father worked as a time-study engineer in Windsor and was laid off one year, resulting in the loss of the family home and Sylvia was "hit hard" by this experience. ${ }^{401}$ She was also keenly aware of the stigma of being an immigrant. Her father joined the local Toastmasters Club to improve his English because he'd been advised to "lose the accent" in order to increase his career opportunities. Although his English improved, she still overheard discriminatory comments from other people, such as parents at a school meeting, who said, "Oh, he speaks quite well, despite the fact that he was a foreigner".,"402 These events reinforced her natural inclination to identify with "the underdog" and to be unafraid of the potential risks of belonging to a union - the risks of not belonging were greater. ${ }^{403}$ Finn's father, a former member of the Royal Air Force and aeronautical engineer, had brought his young family from England to Canada after World War II when he "ran out of money and it was very difficult to get jobs." ${ }^{\text {"404 }}$ Eventually he

\footnotetext{
${ }^{400} \mathrm{~S}$. Gruda, oral history. DP is an abbreviation for displaced person, a term used to describe people forced to migrate from their native countries after World War II.

${ }^{401}$ Ibid.

${ }^{402}$ Ibid.

${ }^{403}$ Ibid.

${ }^{404}$ P. Finn, oral history.
} 
joined the Canadian Air Force and the family lived in Ottawa twice over the course of his career. Her mother sometimes had opportunities to work, if the family was based in a large enough community, and apparently would "rather have worked ... it meant a certain degree of independence, of not having to ask for money to do this or to do that. It's independence. ${ }^{\not 405}$ These early experiences did not necessarily directly inform her support for workplace justice but she certainly had no illusions about the permanency of work or the difficulties faced by women whose working lives were interrupted by their roles as mothers and wives. In any case, her commitment to unionization appears to have been fueled as much by a natural sense of justice and outrage against disrespect as it does from past experiences.

Thus supporters and opponents of unionization were not part of ideologically homogenous groups - either within or between their respective camps. CUSSA representatives were able to gain substantive support in the first year of the operation of the association but were struggling to recruit new members by the following year. Their success in "signing up" administrative and technical support staff was contingent, in part, on framing solidarity in a way that resonated with these employee groups and their ability to recognize when they needed to reposition collective action in order to overcome enough of the lingering resistance and achieve the OLRB's 55\% requirement of members supporting unionization.

\section{Part B. Framing the Issues and Securing Support}

From the beginning, support staff labour activists knew that communication was critical to the success of the CUSSA union drive and that a newsletter could be an

\footnotetext{
${ }^{405}$ Ibid.
} 
effective tool for reaching potential members who were spread out in offices and labs across campus. Volunteers produced the first issue of official newsletter, the What?, in either 1973 or early 1974 and the publication was designed as a public forum for members' to voice their opinions. ${ }^{406}$ While the newsletter was intended for the use of all members, the association leadership leveraged this space to encourage member participation in association activities as well as educate and mobilize support staff employees to support collective action. There were approximately nine issues published irregularly between 1973 and March 1976, when the OLRB granted bargaining agent status to CUSSA. ${ }^{407}$ Using content and layout, the editors and contributors reported selected events and information, which they framed in key narratives that frequently featured an oppositional "employee versus employer" relationship. These written pieces, often supplemented with graphic images, defined particular work-related problems, identified the cause(s) and then suggested solutions. Overall, their goal was to present a moral interpretation of workplace issues at Carleton that would be meaningful to the majority of support staff. The messaging was not static: the organizers' ability to achieve solidarity was due in part to their ability to respond to changing circumstances with new narratives. In hindsight, the process of building support for certification evolved in two phases. The first occurred roughly between late 1973 and March 1975 and featured the narrative of the "worker's plight." The layoff of technical support staff and the certification of CUASA in March 1975 punctuated this story and triggered the shift into the second stage where CUSSA organizers framed collective action in terms of the need

\footnotetext{
406 Sussman, "President's Message."

${ }^{407} \mathrm{I}$ have been unable to find a complete set of newsletters from this period so this is my best estimate of the number produced prior to certification.
} 
for more "clout." The common thread throughout this process, however, was the improvement of the occupational status of support staff.

During the initial phase of the campaign, newsletter content focused primarily on foundational workplace issues such as low salaries, inadequate training and the lack of a formal grievance process. This editorial strategy was designed to establish the legitimacy of the idea of "the workers" plight" at Carleton and the appropriateness of collective action as a strategy for gaining a voice in order to respond to poor working conditions. ${ }^{408}$ In articles, reports, opinion pieces and news items, editors and contributors argued that support staff at Carleton worked in difficult conditions that were taking a toll on the university. There was "significant support staff unrest" at this time and, while "good people" might initially be attracted to the institution to work in administrative, technical and clerical jobs, they did not stay and by late 1974 turnover was high. ${ }^{409}$ Employees were leaving to take jobs with other local employers such as the federal government ${ }^{410}$ "because they can do better elsewhere or for whatever personal reasons they have."411 Doing better elsewhere meant leaving the "badly paid" jobs at Carleton, which had always trailed the salary scales for both non-governmental and the federal civil service in particular where wages could be from 21 to $27 \%$ higher. A fall 1974 editorial entitled "Has everybody got enough of this stuff?" (see Illustration 4.1) argued that Carleton

408 "Has everybody got enough of this?,"the What? 1, no. 3 (n.d.): 1, FN 13, Chapter 1.

${ }^{409}$ C.J. Hidson and Gerry Black, "A committee is: Report from the Salaries and Benefits Committee," the What? 1, no. 4 (n.d.): 3, FN 13, Chapter 1. Apparently the issue of support staff appointments, turnover and dismissals was also address by university representatives in a presentation of the Ontario Council of University Affairs. This presentation referred to the elimination of "sixty positions in the non-academic and academic support areas. Twenty-three of these were in the library, twenty-three from support staff in the Faculties and fifteen in other areas." The presentation also referred to a turnover rate for support staff of $30 \%$. An excerpt was printed in a CUSSA bulletin sent to staff on June 24, 1975.

410 "Flash!!!" the What 1, no. 4 (n.d.): 7, excerpt from an article in the Ottawa Journal (Tuesday, November 19): 5, FN 13, Chapter 1.

${ }^{411}$ Perron, "Internal Report," the What? 1, no. 3 (n.d.): 4, FN 13, Chapter 1. 
support staff workers not only had amongst the lowest salaries in the area but were losing even more "purchasing power" as prices on essential items such as food went up exponentially as inflation rose to an estimated $11.4 \%{ }^{412}$ These costs were "frightening" and, "as usual, it's the worker who's the hardest hit." ${ }^{413}$ Effectively, the "plight" of Carleton support staff employees was to endure a low occupational status - their work was unappreciated and they were compensated accordingly.

\section{Illustration 4.1 "Has Everybody Got Enough of This Stuff?"}

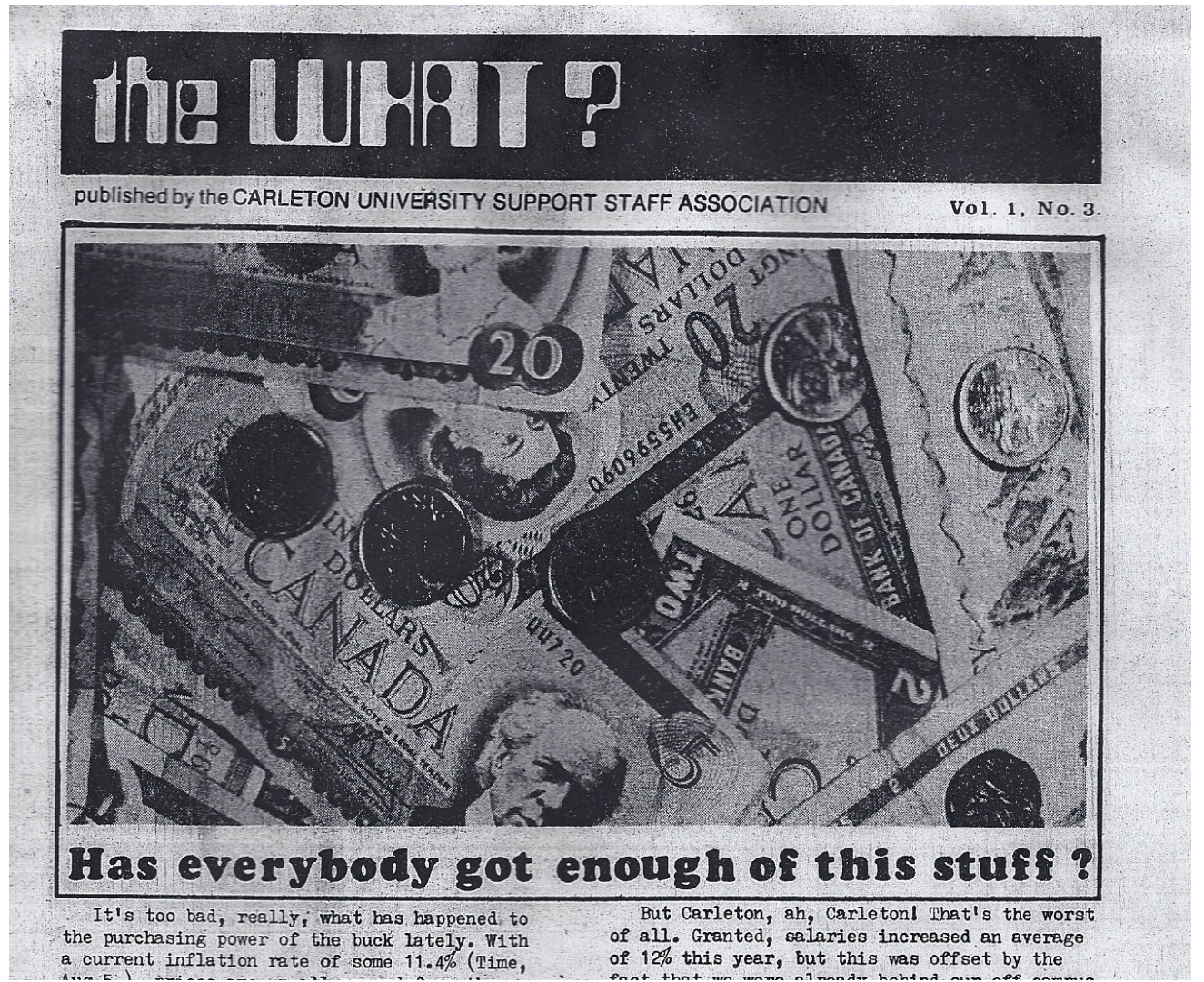

The workers' "plight." The CUSSA newsletter often contained information about the comparatively low salaries at Carleton relative to those offered by other local employers. the What? 1, no. 3 (n.d.).

412 "Has Everybody Got Enough of This?," the What? 1, no. 1 (n.d.): 1, FN 13, Chapter 1. ${ }^{413}$ Ibid. 
In general, newsletter editorials defined low occupational status as the product of management's on going, and remarkable, lack of regard for the work done by support staff at the university. Support staff jobs were essential to the day-to-day functioning of the institution - as important as professional and administrative work - and to the nation.

Without us, the physical plant would not exist, nor would the necessary bureaucracy. There would be no environment in which to study or teach. Our contribution to the well-being of Carleton, and the furtherance of Canadian society is as valid as that of the Administration or Faculty ... we are being ignored at the best of times, and right now on this very important issue. ${ }^{414}$

The on-going relationship with senior managers including President Oliver, VicePresident (Administration) Larose and Director of Administrative Services Brombal, was deeply unsatisfactory because all support staff heard was the "familiar refrain":

University policy toward the plight of the support staff remains the same, fixed and immovable ... they are willing to accept our ideas, our help and our donations to the cause, but they are not willing to accept us. ${ }^{415}$

While disrespect was the main cause of poor working conditions, increasingly during this phase newsletter articles also acknowledged that poor salaries and benefits could be attributed to a lack of public funding for higher education. CUSSA council members began to discuss the "erosion of operating grants" and there had been indirect references to insufficient operating support over the year in several editorials. ${ }^{416}$

CUSSA's first president, Paul Sussman, maintained that the solution to the general problem of the "workers' plight" was collective action: with a majority of members, association representatives would have greater influence on the decisions of university

${ }^{414}$ Ibid.

415 "That Familiar Refrain," the What? 1 no. 4 (n.d.): 6, FN 13, Chapter 1.

${ }^{416}$ Shawn Haley, "COUSA becomes a reality," the What? 1 no. 4 (n.d.): 1, FN 13, Chapter 1. See also "Has everybody got enough of this," and Klimpel, "The Province." 
administrators. ${ }^{417} \mathrm{He}$ recognized that there were at least two options for formal collective action: an internal union and going "external." However, he urged support staff to "JOIN CUSSA" rather than another labour organization if they wanted to see substantive positive change in the workplace. ${ }^{418}$ Likewise, he and other CUSSA leaders believed that solidarity at the provincial level was essential to improving terms and conditions of work and endorsed the association's participation in the newly formed provincial confederation of staff associations. ${ }^{419}$ As Shawn Hayley, the grievance committee chair, argued, the confederation would provide support staff with a "powerful voice ... It is still very young but already is strong. It will grow in stature and WE will prosper." ${ }^{420}$

It is difficult to measure the impact or success of the "moral grammar" of the "workers' plight" at this stage of the campaign. Clearly employees such as McEown, Aldridge and Newton remained unconvinced (of either employee suffering or unionization as a solution to work-related problems) and none mentioned reading the newsletter during this period. In fact, Newton's recollection is that,

I probably wouldn't have talked to people that would have been inclined to be pro. I would be more inclined to talk to someone that shared my views. Because I never really liked confrontation ... so I wouldn't have put myself in a position where I would have to get into a lengthy discussion on something which could be argumentative in the end. ${ }^{421}$

Nonetheless, newsletter reports claimed that support was growing. While in June 1974, Paul Sussman wrote that membership had dropped off significantly after CUSSA was formed, in the next issue of the newsletter, he was "fairly elated" because he was seeing

\footnotetext{
417 Sussman, "President's Message."

418 Ibid.

${ }^{419}$ Later to be renamed the Confederation of Ontario University Staff Associations or COUSA.

${ }^{420}$ Klimpel, "The Province."

421 A. Newton, oral history.
} 
"a large wave of interest in CUSSA ... people are getting their bodies in gear." ${ }^{, 422}$ His excitement was backed up by the membership committee's report in the same issue of a general increase in enrolment, although it is impossible to know if new members were older, younger, female or male. ${ }^{423}$ Sussman resigned soon after but, in her first message as acting president, June Landsberg sent a message that was consistent with his.

Responding to the perennial question "What good is the Association?," she wrote:

Have you asked yourselves what alternative is there to CUSSA? The answer is none - only by working together as a strong effective group can we hope to force the University administration to bring about changes effecting the salaries, benefits and working conditions of support staff at Carleton. ${ }^{424}$

Although her tone was generally less strident than Sussman's, Landsberg continued to argue in favour of solidarity and, in the next issue, the salary report echoed this position by stating that "Carleton support staff must be completely unified ... basic requirements are the same whether you be technician, library assistant, administrative support, or parking lot attendant. Each provides an essential service to the University." ${ }^{425}$

Then the technical support employees were laid off and CUASA filed its certification application. At this major turning point, the What? editors capitalized on the mounting fears of support staff by reinforcing the need for collective action. A front-page opinion piece, entitled What's going on here?, took the entire front page of the publication. Dominating the editorial was a large graphic image of a emblazoned with the epitaph "R.I.P 15 years of service to Carleton," sounding a death knell for both support staff job security on campus and administrative complacence (see Illustration 4.2). Readers were warned that while they might believe that the "great flap about

\footnotetext{
${ }^{422}$ Sussman, "President's Message."

${ }^{423}$ Fern Small, "A Committee Is: Membership," the What? 1 no. 2 (n.d.): 4, FN 13, Chapter 1.

${ }^{424}$ June Landsberg, "President's Message," the What? 1 no. 4 (n.d.): 8, FN 13, Chapter 1.

${ }^{425}$ Ibid.
} 
redundancies had died down," in fact their jobs were at risk as more redundant positions would be declared "when the crunch comes" in the following year. ${ }^{426}$ The university would face a "budget squeeze" and support staff could not expect fair treatment under the current government funding formula. Moreover, administrators played "word games"

\section{Illustration 4.2 "What's going on Here?"}
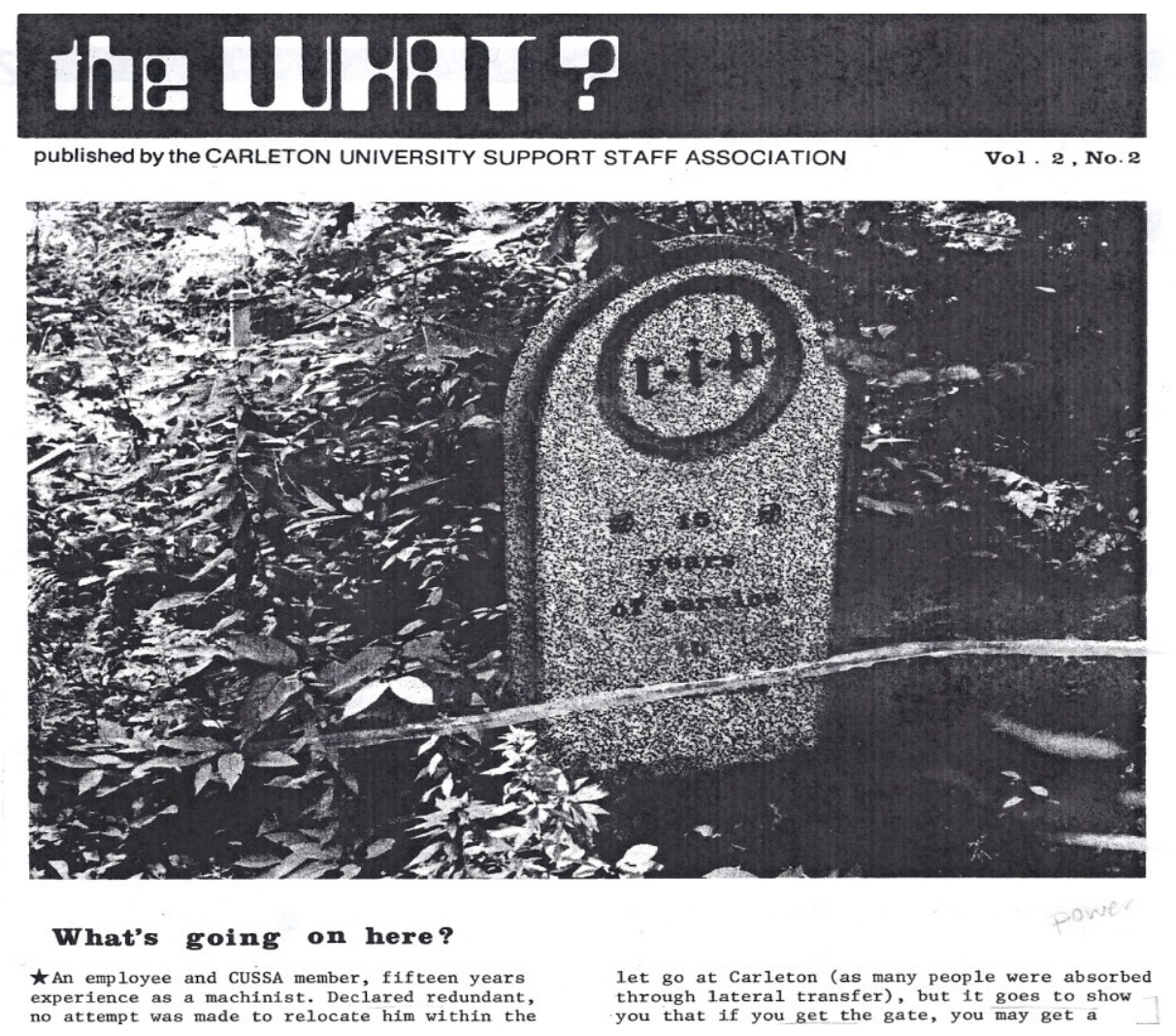

Carleton support staff felt threatened after the lay-off of two technicians and the editors of the What? capitalized on this negative feeling to encourage support for certification. the What? 2. no. 2 (n.d.): 1.

and did not follow official policies, preferring to "break the rules" such as those in the published Redundancy Policy. ${ }^{427}$ For support staff, the solution was to demand act

\footnotetext{
426 "What's Going on Here?," the What? 2, no. 2 (n.d.): 1, FN 13, Chapter 1.

${ }^{427}$ Ibid.
} 
together and an explanation and, by implication, better treatment. "The administration should remember what good faith is ... the support staff will no longer be intimidated. They had better learn to live with us, for we are not going away this time., ${ }^{, 28}$ This article was clearly not a news report. The colourful, emotive language, such as describing jobs as "up the spout" or an employee's situation being one of "if you get the gate, you may get a kick with it" seems chosen to heighten a sense of injustice amongst readers; the tombstone image — evoking death and loss — to trigger strong feelings such as anger and fear.

The overt focus on the "plight" of support staff disappeared and the main issue became having enough "clout" to influence the decisions related to support staff work. ${ }^{429}$ The next issue featured a front-page story entitled Certification - Yes or No? that addressed the issue of institutional power directly, suggesting that support staff had to decide if they "believed" they should have more authority. Readers were reminded that 800 Carleton support staff (including CUSSA members) were still non-unionized and unable to influence decisions regarding their terms and conditions of employment. While the immediate challenges could be understood in terms of the financial "crunch" caused by the provincial higher education funding model, the university's support staff employees were still unable to work with institutional administrators who seemed to consistently resist engagement in "meaningful" discussions. In addition, by 1975, unionization had become an acceptable option for many white-collar workers as "every level of society including the trades, teachers, professional engineers ... are making use of the collective bargaining system to achieve meaningful communication between

\footnotetext{
${ }^{428}$ Ibid.

429 "Certification-Yes or No?," the What? 2, no. 3 (July/August 1975): 1, FN 13, Chapter 1.
} 
employer and employee." ${ }^{430}$ Other provincial university staff associations were also engaging in formal collective action and were either unionized or in the process of seeking certification. Most importantly, the faculty association was now certified. By implication, regardless of the options, a vote in favour of collective bargaining at Carleton would not be such a radical change and, therefore, a good long-term solution to workplace problems.

Phyllis MacRae could have been written this anonymously penned editorial. As she explained in her field placement report, her job was to "chip away at the resistance of the remaining holdouts, most of whom were determinedly anti-union. ${ }^{.431}$ McRae recalls that in this new phase of the union drive, CUSSA executive members clearly articulated the degree of their institutional influence in terms of the low status of support staff relative to other occupational groups and were concerned about losing even more authority—i.e., "being squeezed out."

Now that the faculty and the librarians were unionized ... the support staff would have been the only non-unionized group. And I know June felt very strongly, and others agreed, that if they didn't unionize they were just going to be squeezed out. No one was going to be interested in them, no one was going to protect their interests ... they'll bargain with everybody else on the campus, and then they'll say, "Well sorry, we have no money because you know what? Those greedy faculty they took it all." ... it's not that they disliked the faculty or anything, but ... to say, "Gee, the pot's empty." ... that was a pretty compelling argument. ${ }^{432}$

Effectively, CUSSA organizers believed that amount of support staff clout was dependent on their status in the occupational hierarchy. Their work was identified as the least skilled, least valuable of the white-collar categories and they would make no gains if they counted on the good will or faith of university administrators. However, the executive

\footnotetext{
${ }^{430}$ Ibid.

${ }^{431}$ MacRae, Field Placement Report, 1.

${ }^{432}$ P. MacRae, oral history.
} 
council members were determined to proceed cautiously in order to overcome the remaining resistance amongst potential members.

In her report, MacRae stated that she believed members should be pushed towards a "trade union consciousness" but that the executive only wanted to get through the legal process smoothly. As such, the newsletter would not be a vehicle for education and McRae was not to write articles that were "inflammatory." Although not included in her official report, MacRae also recognized that CUSSA leaders believed that they would not gain support for membership in a trade union - even if a larger organization might mean a louder "voice" and more power.

CUPE was the main group that was available and ... was soliciting actively that this group should join them. So that was the debate ... they were uncomfortable with being a real union and being kind of blue-collar ... and I think June ... thought that if they would agree to go with CUPE or you know, one of the other unions, that would be good. But she recognized that they wouldn't. So ... you have to pick the battles. ${ }^{433}$

Interestingly, the newsletter contained virtually no mention of CUPE, except for Lothar Klimpel's early article on the dangers of unions and the occasional reference in the context of reports on the work of the provincial confederation of staff associations. While joining a trade union was not an option, the executive had effectively taken an aggressive, even unionist approach to collective action in the previous issues of the newsletter.

Content had avoided the use of familiar union concepts such as solidarity or exploitation; members and potential members were not referred to as "brothers and sisters"; nor were threats made of job action or possible strikes. However, the tone of many pieces could be described as confrontational—critical of management in general and particular

\footnotetext{
${ }^{433}$ Ibid.
} 
administrators specifically and some of the contributors called for CUSSA to apply pressure or take direct action. ${ }^{434}$

In addition to remaining silent on the issue of trade unions in the newsletters, the editors also chose to avoid framing certification in terms of women's rights (as had faculty and librarians). The December 1975 newsletter did include a short news report that CUSSA had a Committee on Equal Rights for Women and Men (CERWAM) and that two members of this committee had, in turn, been appointed to the Presidential Advisory Committee on Equal Rights—including Pat Finn. The committee terms of reference included review of existing policies as well as the identification of new employment policies "where needed, for ending any sex discrimination, and for breaking down sex typing of employment categories. ${ }^{435}$ However, this is the only mention of the issue of sex discrimination in the workplace, despite the fact that key organizers such as Gruda and Finn felt passionately about gendered workplace injustices. Perhaps this omission is not surprising, given the apparent tensions between men and women within CUSSA. It is possible that some organizers recognized that the generic identification of support staff as "workers" might in fact appeal to more individuals, or at least a broader cross section, than divisions along sex lines, which had led to further conflicts within in the association and alienated some of the men who had originally supported CUSSA. Table 4.1 shows the difference in salary scales between the administrative and technical staff that definitely created substantive monetary differences between the two occupational groups. There were 120 men and 20 women in the technical category and 78

${ }^{434}$ Shawn Haley, "Re: 18\% Salary Increase for Support Staff, 1975-1976" (letter to the editor), the What? 2, no. 1, (n.d.): 2, FN 13, Chapter 1.

435 "Equal Rights Committee," the What? 2 no. 5 (December 1975): 7, FN 13, Chapter 1. 
men and 407 women in the administrative category. The average salary for men was $\$ 9,503$ and for women it was $\$ 7,957$.

Table 4.1 Administrative and Technical Classification Levels and Salaries ${ }^{436}$

\begin{tabular}{lll}
\hline Administrative Ranks & Low Salary & High Salary \\
\hline AS7 & $\$ 9,600$ & $\$ 12,000$ \\
AS6 & $\$ \mathbf{\$ 8 , 4 0 0}$ & $\mathbf{\$ 1 1 , 0 0 0}$ \\
AS5 & $\mathbf{\$ 7 , 2 0 0}$ & $\$ 9,700$ \\
AS4 & $\$ \mathbf{6 , 3 0 0}$ & $\mathbf{\$ 8 , 7 0 0}$ \\
AS3 & $\$ 5,700$ & $\$ 7,600$ \\
AS2 & $\$ 4,900$ & $\$ 6,900$ \\
AS1 & $\$ 4,400$ & $\$ 5,800$ \\
\hline
\end{tabular}

\begin{tabular}{lll}
\hline Technical Ranks & Low Salary & High Salary \\
\hline TS7 & $\mathbf{\$ 9 , 6 0 0}$ & $\mathbf{\$ 1 2 , 0 0 0}$ \\
TS6 & $\mathbf{\$ 8 , 4 0 0}$ & $\mathbf{\$ 1 1 , 0 0 0}$ \\
TS5 & $\mathbf{\$ 7 , 2 0 0}$ & $\mathbf{\$ 9 , 7 0 0}$ \\
TS4 & $\$ 6,300$ & $\mathbf{\$ 8 , 7 0 0}$ \\
TS3 & $\$ 5,700$ & $\$ 7,600$ \\
TS2 & $\$ 4,900$ & $\$ 6,900$ \\
TS1 & $\$ 4,500$ & $\$ 5,700$ \\
\hline
\end{tabular}

This data appeared originally in the Status of Women report that Pat Finn prepared for President Oliver in 1975.

Throughout the three-year campaign for collective action and institutional recognition, CUSSA organizers met with some resistance from university administrators that culminated in the refusal of senior managers to voluntarily recognize the association as the bargaining agent for support staff. Organizers felt frustrated, if not outraged, but once the decision to apply for certification was taken, senior university officials do not appear to have erected roadblocks that would seriously disrupt or delay the legal process. Finn does remember some low-key responses that were irritating to her at the time but not particularly threatening.

\footnotetext{
${ }^{436}$ Finn, Status of Women.
} 
I don't remember [it] being big and public, largely because they didn't think we could do it. So when we did do it they were kind of caught off guard, and they were still kind of in shock over the fact that the faculty had done it because we were right after them, which was a big factor in being able to do it ... it certainly shut up those people who said, "It's not professional, so if the faculty can do it why can't we?"

That letter from Larose sort of challeng[ed] us to go do it ... [and] they would come by and sort of laugh at us on the way into the elevators to go up to the sixth floor of Robertson or say, "How's it going today Pat, did you get anybody to sign up?"137

In addition, university representatives did suggest that CUSSA not be granted an interim certificate prior to the final decision from the OLRB on the composition of the bargaining. ${ }^{438}$ These reactions do not seem overly aggressive and Don McEown offers an alternative perspective on this lack of any "argument" from university administrators.

If the staff wanted to unionize, they had perfectly legitimate right to unionize and we weren't going to do anything to stop them ... that was the president's view ... And I don't think ... Albert [Larose] was going to be make life more complicated $\ldots$ after having gone through the faculty. ${ }^{439}$

Institutional hostility had certainly been a significant barrier to unionization for other Canadian workers, particularly in the private sector and employees at the University of Saskatchewan had to contend with the attempts by President Walter P. Thompson to delay the certification process as had union representatives who tried to organize clerical staff at the main campus of Columbia University. In contrast, whether as a product of President Michael Oliver's "lefty" leanings or a desire to avoid further animosity, university administrators consistently refrained from any "undue influence" over the process of certification for all three employee groups.

${ }^{437}$ P. Finn, oral history.

${ }^{438}$ June Landsberg, memo to all members, June 20, 1976, Carleton University Support Staff Association fonds, CUSSA-001-8, Miscellaneous News and press releases, 1974-1981, Carleton University Corporate Archives, Ottawa, Ontario.

${ }^{439}$ D. McEown, oral history. 
The moral case for certification was thus essentially a two-part argument based on the concepts of "the workers' plight" and the "need for clout." However, an eventual vote in favour of certification was not necessarily a vote in favour of unionism. For Bette Smith, the final outcome reflected "more of a feeling of, we're going to probably unionize, and we're going to hold our nose" and MacRae's impression was not only of reluctance to accept the idea of unionization but also that that acceptance was conditional upon belonging to a particular type of union.

It was like, "Only if we can be ... an independent, certified bargaining unit ... if we have to do this then we will, but ... not with one of those other unions that will make us go on strike, because that's what people tell you. You know they want to go on strike and you'll be made to go on strike. And, I can't afford to go on strike. $^{440}$

Therefore, the majority of support staff might ultimately have joined CUSSA and voted in favour of certification of the staff association but did not, in so doing, become trade unionists; they may have supported collective bargaining rights and processes but not working-class organizations.

\section{Conclusion and Epilogue: "Equal Pay for Work of Equal Value"}

CUSSA negotiators presented their first "monetary and non-monetary demands" to the Carleton negotiators on May 7, $1976^{441}$ and formal negotiations began the following month. ${ }^{422}$ Although the CUASA negotiations resulted in a contract within six months of certification being granted, it took almost eighteen months to ratify the first collective agreement between support staff and Carleton University. Sitting on the union's team were three men and three women:

\footnotetext{
${ }^{440}$ P. MacRae, oral history.

${ }^{441}$ June Landsberg, "President's Report", the What? (November 18, 1976), FN 13, Chapter 1.

442 "Negotiating Team in Action," the What? 3, no. 1 (Spring 1976): 1, FN 13, Chapter 1.
} 
- June Landsberg (President; Instructional Development)

- Sylvia Gruda (Internal Vice President; Library Support)

- Gerry Black (External Vice President; Business Office)

- Pat Chartier [Finn] (Purchasing Department; Administrative Support)

- Larry Speers (Biology Department; Technical Support)

- Phyllis MacRae (CUSSA Certification Co-ordinator) ${ }^{443}$

Some of the delay can be explained in terms of the need to make a submission to the federal Anti-Inflation Board related to the compensation provisions of the collective agreement. ${ }^{444}$ The time lag was also the result of divisions amongst CUSSA negotiators: "it came down a lot of the time to [a] complete split between the genders." ${ }^{445}$ Pat Finn found these divisions stressful, in part because June Landsberg remained impartial.

June decided she had to be neutral because she was the president and chief negotiator ... which left Sylvia and I in "our little corner" and doing the more radical things and then [the] men [who were] certainly much older ... So it was this tension and she wanted to be the peacemaker rather than align with the feminists that much and it got to be an issue.

One core area of dispute was maternity benefits, which Finn and Gruda wanted to secure given that no government provisions for leave existed prior or after the birth of a child.

To Finn's disappointment, CUSSA council members rejected the proposal and maternity leave was not included in the first contract.

Even before we got to the table we had a proposal that went to council for maternity leave and this was in the days before there was maternity leave of any kind ... and we got shot down by council on the grounds, "Well this was discriminatory because it was only for women" ... I can remember leaving that council meeting in tears. ${ }^{446}$

443 "Negotiations and Contract," the What? 2, no. 5 (December 1975): 1, FN 13; "Negotiating Team in Action," 1.

444 "Joint CUSSA-Administration AIB Submission," the What? 4, no 1 (February 1977): 1, FN 13; Chapter 1. CUSSA Newsletter, 1, no. 1 (April 15, 1977): 1, FN 1, Chapter 2.

${ }^{445}$ P. Finn, P. Finn and S. Gruda, oral history.

${ }^{446}$ P. Finn, oral history. 
Disagreements continued and at one point Gruda confessed to Finn that, "she was getting really tired of sounding like chief bitch." ${ }^{, 47}$

Nonetheless, the team preserved, with support from members of the CUASA negotiating team such as Derek Sida and Jill Vickers, ${ }^{448}$ and a tentative agreement was finally reached in June 1977 and ratified by $80 \%$ of the 375 CUSSA members who cast ballots in the ratification vote on November $17,1997 .{ }^{449}$ Included in the agreement were articles related to standard provisions such as strikes and lock-outs, grievance and arbitration procedures, overtime and a range of leaves and the waiver of tuition fees. ${ }^{450}$ Missing were provisions for maternity leave and new job classifications - those that Finn had recorded for her report on the status of support staff and students at Carleton the previous year were left intact and embedded in the agreement. On balance, Finn and Gruda are justifiably proud of the agreement. Not only did they "manage in the end to hang onto equal pay for equal work value which in 1976 was a pretty big thing" but some of the men who had opposed provisions that would have directly benefited women later changed their position. Although we didn't get maternity leave, ... one of the men who voted it down came up to me afterwards when his wife had twins and said, "I'm so sorry Pat I didn't realize you were right, I was wrong" but too late. Never did get it until the government did. ${ }^{451}$

${ }^{447}$ Ibid.

${ }^{448}$ Ibid.

${ }^{449}$ Notice to CUSSA members, "Results on the Ratification Vote Held November 17, 1977," November 17, 1977, Carleton University Support Staff Association fonds, CUSSA-001-8, Miscellaneous News and press releases, 1974-1981, Carleton University Corporate Archives, Ottawa Ontario.

${ }^{450}$ Collective Agreement between Carleton University and Carleton University Support Staff Association (hereafter CUSSA-CU Agreement) for the Period July 1, 1976 to June 30, 1977, in the author's possession.

${ }^{451}$ P. Finn, S. Gruda and P. Finn, oral history. 
In addition, while over time the relative occupational status of support staff has remained below that of professors and librarians, successive negotiating teams have succeeded in gaining greater recognition for the complexity of administrative and technical support work that has translated into higher pay scales. As Gruda points out, "the job I did as a level 2 is now a level 8 in the library" and, as a result, the status of women on campus has improved to some extent. ${ }^{452}$ CUSSA remained an independent union until 1980 when members voted to dissolve the association and become CUPE Local 2424. After more than four years as union members, support staff employees were ready to align themselves to a greater extent with the larger labour movement in Canada.

${ }^{452}$ S. Gruda, oral history. 


\section{Chapter 5 Conclusion: Noisy, Uppity and Organized}

A noisy campus - that is how Richard Van Loon has described Carleton

University in conversations with colleagues and staff about the university. Van Loon uses this epithet with affection and respect for an institution where he was a student, professor and president. ${ }^{1}$

It was a community developed institution, it was always very open ... so people were never in the least bit shy about saying what they thought about the university administration or anybody else around the place so there was always a certain amount of demonstration going on.

He was on campus during the 1960s and then latterly in the 1990s and 2000s, so his comments do not refer directly to the years during which CUASA and CUSSA certified but his observation is nonetheless apt for that period too. The collective action of faculty, librarians and support staff in the mid-1970s was indeed a protest and while the librarians were relatively less visible, separately both academic and non-academic support staff employees were vocal in their criticisms of university managers. In particular, each produced newsletters that were widely distributed across campus - available to any interested reader — and group activities were reported regularly in the university's official publication, This Week Times Two. ${ }^{2}$ Their noisiness also spilled over into the broader community when they became openly united as members of the "Common Front," an

\footnotetext{
${ }^{1}$ R. Van Loon, oral history. As per the information on the Archives and Research Collections website, Richard Van Loon graduated from Carleton with a BSc (Chemistry and Geology) in 1961 and an MA in Political Science in 1965. He completed a PhD in political science at Queen's University and returned to Carleton as an assistant professor in 1970. He left the university in 1972, before the CUASA certification campaign began, and had a career as a public service with the Government of Canada before returning to the university as president of Carleton University in 1996, a position he held until 2005. In the 1990s the university administrators made a number of significant cuts to spending, involving the closure of programs and reorganization of staff, due to yet again significant financial challenges. Archives and Research Collections, Carleton University, , accessed November 27, 2013, http://arc.library.carleton.ca/exhibits/oral_history/richard_van_loon.

${ }^{2}$ The student newspaper, The Charlatan, was given responsibility for This Week Times Two in March 1975. "Media Takeover on Campus. The Charlatan Acquires TWIT," The Charlatan 4, no. 29 (March 31, 1975): 1, FN 373, Chapter 2.
} 
Ottawa-wide campaign of "students and workers" to protest the current cuts to provincial spending on a range of social programs including post-secondary education. ${ }^{3}$ Yet on campus their "community of interest" was considerably less obvious, hidden behind work-related boundaries that were thick and seemingly impenetrable. These borders were socially constructed, drenched in traditional ideas about sex differences; they were complicated by the variety of forms of work and employment practices such as job classification system, organized along a gendered occupational hierarchy.

This case study of union drives at Carleton is historically relevant in two respects. It is an opportunity to record the details of the process of unionization from the perspective of employees whose stories have not previously been told. It is also an occasion to step around occupational divisions and gain a greater understanding of the meaningful experiences and concerns shared by Carleton support staff, librarians and professors, and perhaps other workers. In particular, the histories of the certification of CUSSA and CUSSA reveal that status was a crucial factor in both support for and resistance to collective bargaining. Not merely layers of stratification or "objective categories of occupation and income," employees represented a symbiotic relationship between occupational identity and social standing that led to struggle and, in essence, became a shared grammar of dissent. Triggered by the immediate fear of job loss, academic and non-academic employees were also driven by a long-standing desire to protect or improve their working conditions, and to gain respect for their contributions to the university. When the women and men of

\footnotetext{
3 “Common Front. A Common End,” The Charlatan 4, no. 25 (Friday, February 21, 1975): 1, FN 373, Chapter 2.

${ }^{4}$ Craig Heron, "Harold, Marg and the Boys: The Relevance of Class in Canadian History," Journal of the Canadian Historical Association/Revue de la Société Historique du Canada 20, no. 1, 2009: 4.
} 
three different groups mobilized, they arrived at exactly the same end-point: an independently certified union that had the legal power to guard their interests but was consistent with their occupational identities as white-collar/white blouse workers. Moreover, women played a leading role in the union drives, fueled by outrage at a systemic discrimination that placed them in positions of disadvantage in a workplace that was relatively privileged.

As Craig Heron observed in his 2009 presidential address to the Canadian Historical Society, labour historians in Canada have written about the mobilization of "working people [mainly] around their distinct class interests ... [and] of unions and political organizations that articulated these goals." As an analytic category, class, he argues, represents "a minefield of theoretical contention ... [because] class ... defies easy definition." ${ }^{, 6}$ But this concept rightly draws attention to what British political and social theorist Diana Coole refers to as the persistent and observable "structured economic inequality" in capitalist economies. Such inequality has a significant impact on the quality of life, both materially and culturally; it can lead to "alienation, exploitation, commodification" and, in turn, to collective action. In other words, class matters. ${ }^{7}$ Canadian labour historiography has attended particularly to the experiences of the men and women most visible in the labour conflicts of the $19^{\text {th }}$ and early to mid- $20^{\text {th }}$ century: ${ }^{8}$ those considered amongst the most "subordinate," the blue-collar working class does manual rather than intellectual labour, often located in physically demanding sites of

\footnotetext{
5 Ibid., 2.

6 Ibid., 11.

${ }^{7}$ Diana Coole, "Is Class a Difference That Makes a Difference?," Radical Philosophy 77 (May/June 1999): 24.

${ }^{8}$ In addition to Heron's presidential address, see also Aronowitz, How Class Works. Power and Social Movements.
} 
industrial and resource extracting production and, prior to unionization, for the poorest wages. Less consideration has been given to those white-collar, potentially middle class employees, particularly those working in post-secondary institutions, doing more mental than physical work in service organizations. This lack of analysis stems from the fact that these employees appeared better off, less vulnerable, less discontent, and that they did not represent a significant proportion of the working population until the later half of the $20^{\text {th }}$ century. They were not present, to borrow from E.P. Thompson, "at their own making," or at least at the making of the Canadian working class.

One group of workers, being the most exploited and the most significant actor in labour conflicts and socioeconomic changes, does not, however, preclude the possibility that others are exploited and will eventually be motivated to act collectively towards fundamental social shifts. ${ }^{9}$ In addition, as American sociologist Stanley Aronowitz has pointed out, "Marx never claimed that the working class was the most oppressed or dominated class in the capitalist mode of production, only the most exploited. ${ }^{10}$ Feminist scholars have insisted that oppression on the basis of sex is as critical to any study of socioeconomic struggle as class. ${ }^{11}$ Given the complexity of identities associated with these multiple and competing socioeconomic sources, it is possible that disadvantaged groups may use a moral grammar different from that of class while reflecting some degree of economic deprivation and exploitation. In addition, within groups the same idea can come to inform positions that support and oppose a given form of social action.

\footnotetext{
${ }^{9}$ Aronowitz, The Politics of Identity, 21.

10 Ibid.

${ }^{11}$ See, for example, Sheila Rowbotham, Sally Alexander and Barbara Taylor, "The Trouble with Patriarchy," reprinted in The Feminist History Reader, ed. Sue Morgan, (New York: Routledge, 2006): 52.
} 
One of the first interviews done for this research was with Professor Blair Neatby. In the course of the conversation, he made numerous references to "status" or "prestige," as he and Don McEown had done in their brief discussion of faculty unionization in Creating Carleton. Struck by his persistent use of these terms, I began to listen for similar references in the other stories I collected and in the written evidence. The historical accounts proved to be laden with this terminology. This is not the vocabulary of classic labour protest. It is, however, the language that university employees used to describe their struggle for protection and recognition at a historical moment when they saw themselves, to varying degrees, as vulnerable, oppressed and exploited. It reflected their "moral economy."

Female support staff employees at Carleton, particularly those doing administrative work, could be seen as the working class of the white-collar employees on campus. Granted, they were not working in mines, factories, fish processing plants or sawmills but their wages were low, their work heavily regulated, and they harboured a persistent sense of being treated unfairly. As far back as 1942 when Dorothy Wardle began to work at Carleton College for President Tory, those doing administrative work at Carleton had made an issue of inadequate wages. Life had not changed substantively three decades later when all support staff unionized. The incomes earned by these employees were not enough to support a "breadwinner"—or those who might have liked to live independently, without parents or roommates. Bette Smith lived at home with her parents while she was working as a "Steno 3" at the university because, she recalls, "I made $\$ 3,500$ a year which at that point wasn't enough to live on by yourself, even in 
those dollar days. ${ }^{12}$ Likewise, Ann Newton, ${ }^{13}$ whose annual salary as a library assistant was $\$ 3,900$, often "did the roommate thing”: "a lot of our money went to rent ... there's no way you could have lived in a normal place and paid like $\$ 500$ or $\$ 600$ because you weren't making that kind of money." ${ }^{\prime 14}$ If Pat Finn, a lead organizer for the Carleton University Support Staff Association (CUSSA), was able to support herself and her husband during her early days at Carleton, it might have been because of the tuition benefit that paid for his fees. In contrast, the technical support staff employees (who were in the minority in this employee category) were better off. They were mostly male and could make more money than female technicians or administrative staff; in fact, most earned more than new female librarian Frances Montgomery. Although, those doing this work, such as Ian Babcock, could see their wages diminish by taking a job at Carleton where historical salary levels were consistently lower than at other local organizations, benefits could be considered to be competitive.

Administrative and technical employees all had workdays that could be highly structured, and over which they had little control. Whether they were located in the library, a science lab or the purchasing department, they had a supervisor who was responsible for assigning the work and who had the authority to set hours of work (including shifts), monitor rest periods and evaluate their labour in order to set salary scales and award promotions. When a supervisor or manager had a stronger "need to control," the lack of independence became even more visible, as secretary Bette Smith found out.

\footnotetext{
${ }^{12}$ B. Smith, oral history.

13 Ibid.

${ }^{14}$ A. Newton, oral history.
} 
We were always sort of having loggerheads with [our admin. assistant] ... because she'd sort of swoop down to see what we were doing ... we were positive her husband would call about five minutes before 4:30 p.m. just to see if we were answering the phone. But we always knew it was Charles. ${ }^{15}$

Supervisors could also lay off or fire staff, as CUSSA members discovered in 1975 and such decisions were highly dependent on the personality and priorities of individual managers. Don McEown's first job at Carleton in 1963 was as a "jack of all trades" and he quickly became the manager of the fledgling audio-visual department where he supervised technical employees who were treated harshly by his successors:

[It was] ... the beginnings of the audio-visual aids department. We were just getting in the TV in terms of televising lectures ... [and] I had a couple of very idiosyncratic technicians at work all hours of the days and night and just loved their jobs and just playing around ... Unfortunately [they] were ill-disciplined and they lost the jobs once I left. The new managers couldn't stand their ways. ${ }^{16}$

The regimented life of support staff in lower-level jobs was in direct contrast to that of more senior administrative staff who could see themselves as having a "middle class" life. Both Margaret and Don McEown enjoyed what they remember as a working environment where "there was flexibility ... if your kids were sick or something was wrong in the household, you could peel off work and go home ... and people would cover for you."17

When support staff group began to organize, it is the awareness of economic inequalities that mainly informed their mobilization rhetoric: they wore the mantle of class not of status. Newsletter articles regularly featured references to "good people" loosing purchasing power and leaving the "bad pay" at Carleton for something better elsewhere, usually the federal government. The decision to leave was not just the result of economic inequality; it was also a reaction to disrespect. Support workers were frustrated

\footnotetext{
${ }^{15}$ B. Smith, oral history.

${ }^{16} \mathrm{D}$. McEown, oral history.

${ }^{17}$ Ibid.
} 
at being treated as invisible and interchangeable. Taking a job at another institution was one solution but so too was worker solidarity—being united against management in the fight for better pay, benefits and other conditions. This was the strategy to counteract what library assistant Sylvia Gruda and Pat Finn have called the "injustices" experienced working at Carleton. If union organizers such as Gruda steadfastly maintained an allegiance to the working class, class was not the ideology that led to the ultimate success of the certification campaign, and its associated difficulties. Those who did not adopt the discourse of worker solidarity did not perceive themselves to be oppressed or exploited; conditions were adequate in their eyes, and individual merit, not group action, was appropriate for negotiating everything from salary increases to promotions. Already having good relationships with managers who they believed to be looking out for their interests, they did not want to provoke antagonism, even if they were not necessarily as afraid of layoffs as other support staff employees.

The use of the term "clout" cannot be taken out of the context of this particular certification drive. "Clout"- the power to contribute substantively to decision-making and effect positive change - seems to be more consistent with the vocabulary of an oppressed group. In the case of support staff, it was used very specifically to refer to status, the place of administrative and technical support employees within the occupational hierarchy relative to that of professors. The positioning of collective action as a tool for preventing the loss of status convinced those who believed themselves to be decidedly not "working class" that change was advantageous and unionization was a viable strategy — union membership was not framed as the solution to economic 
exploitation but as an opportunity to strengthen their position vis-à-vis another employee group to ensure that they were not "squeezed out."

Librarians were more privileged than support staff. It could even be argued that they belonged to the managerial category of employee, given the fact that they were the library workers who often were hired to eventually become departmental heads and chief librarians. Overall, they could have greater independence and freedom to do their work as well as even plan staff social gatherings such as the Alice in Wonderland-like tea party that librarian Valerie Swinton helped to host with colleagues from another department.

We were serious, we did our work, but it was fun to be young and working then ... I can remember having a tea with the acquisitions department ... and one of the other ladies ... poured tea in the old fashioned way, and we set up a great big table in the middle of our two departments. White tablecloth, silver tea service, and we had red wine in one teapot and white wine in the other. ${ }^{18}$

Nonetheless, they contested some of the same workplace issues as support staff, chronically low wages in particular. Since the $19^{\text {th }}$ century, librarians from across North America had identified inadequate salaries as a significant problem and instituted occupational reforms, including the need for university-level educational credentials, in order to professionalize librarianship and thus improve the socioeconomic status of librarianship. There were other aspects of their work that resembled to some degree that of the non-professional staff with whom they worked with and supervised. Susan Jackson, Frances Montgomery and Valerie Swinton all did shift work that meant regular periods of duty on the reference desk and working evenings as well as weekends. ${ }^{19}$ In addition, much time was spent at the various card catalogues checking and double-checking titles

\footnotetext{
${ }^{18} \mathrm{~V}$. Swinton, oral history.

${ }^{19}$ F. Montgomery, oral history.
} 
in the collection — necessary work that required them to spend hours on their feet. For Montgomery, this could be a two-step process.

I did a big ... business in second-hand catalogues ... you had to act on them right away because you were in competition with other places ... for example ordered Canadiana ... from the States because you could get better prices ... we [also] did a big market with Neihoff in the Netherlands ... And then we'd sort of gather all our catalogues and go down to the main catalogue and check for the better part of the day to make sure that [we] didn't already have it. ${ }^{20}$

Most important, however, were the limits placed on their authority over their own working conditions; ultimately the chief librarian retained the institutional power to determine terms and conditions of work.

When in 1974 the librarians decided to organize, first as the Association of Professional Librarians of Carleton University (APLCU) and then to join the Carleton University Academic Staff Association (CUASA), status was clearly central to the debate. Carleton's first University Librarian Hilda Gifford had created a culture of professionalism in which librarians were encouraged to expect institutional recognition for the complexity of their work and the library's vital role as the "heart" of the institution. Moreover, as professionals they should have a significant role in determining the terms and conditions of their work. Librarians did not portray themselves as amongst the exploited and, of the three groups, they seem to have been the least concerned about the threat of cutbacks. Instead, they remained focused on their right to a relatively elevated status within the university, one that was the equivalent of that of faculty and quite distinct from the other library staff. They were educators and shared a "community of interest" with professors rather than with the non-professional library assistants and

\footnotetext{
${ }^{20}$ Ibid.
} 
other staff below them on the institutional hierarchy, and their moral grammar was devoid of allusions to plight and injustice.

Librarians and faculty were aligned on issue of status: they each did skilled intellectual work that could be described as professional and were determined to preserve this identity and standing. As Paul Axelrod commented later, across Canada the success of academic staff certification drives "invariably depended on how well union organizers could demonstrate their desire to uphold, not overturn, academic traditions and university conventions." 21 Professors were decidedly not proletarian, and the contrast between their working day and that of support staff is striking. While faculty were required to teach, publish original research, fulfil administrative duties and do community outreach, they had tremendous control over choosing the content of this work. They enjoyed an absence of direct supervision, as the departmental chair was more senior administrative coordinator than supervisor. When Carleton historian Naomi Griffiths was teaching, she looked forward to figuring out how to design new course material.

I enjoy teaching and I taught ... the first-year courses [in history] and ... I used to spend August listening to the hit parade because you had to decide in your mind, "What do you want them to know? What do you have to explain to them from where they are, to understand what you want them to know before you teach them what you want them to know? ${ }^{22}$

However, as the dean of Carleton's arts and social sciences faculty in the late 1970s, Griffiths was also very aware that this workload was challenging. She could never forget what it was like "to be $[\ldots]$ an assistant professor trying to get your writing and scholarship recognized with a teaching load that exhausts you."23

\footnotetext{
${ }^{21}$ Axelrod, Scholars and Dollars, 210.

${ }^{22}$ N. Griffiths, oral history.

${ }^{23}$ Ibid.
} 
Despite aspects of their work that were tiring, faculty identity and expectations for standing were firmly rooted in the conception of academic work as skilled, creative, autonomous and, most importantly, vital to the operation and success of the university. In their earliest discussions with senior college administrators on salaries, benefits and other working conditions, they consulted and briefed but did not negotiate. This approach persisted into the 1960s and shaped their interactions with President Dunton—even as they became more assertive regarding the long-standing issue of chronically low salary levels. When the union drive was launched, campaign organizers were careful to avoid terminology that would be incompatible with their visions of the university as members of a "community of scholars," not employees of an institution. They did not talk either about any plight, although privately they were worried about the stability of their employment. Professor Andrew Brook remembers that the thought of job losses "scared a lot of people ... we had young families and we had mortgages and the idea of being suddenly out of work was pretty terrifying. ${ }^{24}$ Instead, as Griffiths suggests, they talked about gaining "more power" in the decision-making process, as did their colleagues at other Ontario universities such as the University of Toronto. ${ }^{25}$

The critical role of status in the unionization of academic and non-academic support staff at Carleton is equally visible in the ultimate decision of all three groups not to join the Canadian Union of Public Employees (CUPE). In keeping with the tradition at other Canadian universities, professors, librarians and support staff initially chose to form voluntary staff associations as a forum to either discuss work-related issues or, at the very least, meet and interact socially. Many similar organizations across the country had begun

\footnotetext{
${ }^{24}$ A. Brook, oral history.

${ }^{25}$ N. Griffiths, oral history. Nelson, Search for Faculty Power.
} 
as social clubs as did the Carleton University Staff Association (the CUSSA predecessor). By contrast, CUASA, the APLCU and CUSSA would receive clear mandates to address employment issues.

When they began to seriously consider certification, all three occupational groups took similar paths again: an alliance with a larger, national organization was considered and rejected. Faculty could have joined CUPE or designated the CAUT as a bargaining agent; the librarians "interviewed" representatives from CUPE and reached out to the PIPSC; library employees tried to certify with CUPE and failed. In each case, a successful union drive was contingent upon respecting the dominant ideas about occupational identity that included the belief that unions were for blue-collar workers, not for white-collar/white blouse employees. If the CUASA, APLCU and CUSSA leaders had opted for membership in a trade union, they would probably not have gained the grassroots support they needed for certification at that historical moment and to this day, CUASA remains an independent staff association. However, CUSSA members would choose another path when, in 1980, they opted to decertify CUSSA and join CUPE because they were once again concerned about being "squeezed out." As contract negotiations "got tougher," and the possibility of not surviving a strike became more definite, ${ }^{26}$ they opted to change the status of the association with the OLRB and become CUPE Local 2424. Belonging to a much larger trade union did not necessarily mean that all members now viewed themselves as "working class," but indicates that many recognized the advantages of access to a generous strike fund and greater "union solidarity. Some support staff might have been concerned about the potential loss of autonomy that could accompany membership in a large, national union. However, Gruda,

\footnotetext{
${ }^{26}$ History of CUPE 2424, (n.d.), 2-3, in the author's possession.
} 
who continued to work at the university until she retired in 2008, remembers being told that as members of a CUPE local, Carleton support staff could expect to have extensive control and decision-making authority. CUPE organizer Ed Scott had made the same promise to the library workers in 1972."

Female support staff may have been the most disadvantaged employees at Carleton at the time of unionization, but when the history of certification is told from the perspective of women across the occupational groups, the impact of shared status concerns is even more obvious - perhaps a sign, as Canadian feminists have argued, that gender is integral to social identity in Canada. ${ }^{27}$ Pat Finn, Sylvia Gruda, Susan Jackson and Jill Vickers all "wore the tag as feminist." 28 The Canadian women's movement was resurging in the late 1960s and early 1970s, due in part to the efforts of activists such as Doris Anderson and Laura Sabia, and women across the country were inspired by international feminists like American Betty Friedan and Australian Germaine Greer. At Carleton, junior professor Deborah Gorham had already taught the university's first course in women's history by 1972 , which was a challenge to the fact that women were still "hidden from history," and in 1976 Naomi Griffiths published her book Penelope's Web: Some Perceptions of Women in European and Canadian Society because she "got so bitterly angry with the way in which the most powerful man was compared to the least powerful woman" who, in fact, could be seen an active agent who "managed power."29 None of the union activists necessarily thought of themselves as "radical feminists" but Finn and Gruda "spoke at things, we attended women's things ... we were in a women's

\footnotetext{
${ }^{27}$ Rebick, Ten Thousand Roses.

${ }^{28}$ P. Finn, P. Finn and S. Gruda, oral history.

${ }^{29}$ N. Griffiths, oral history. Ruth Pierson, “Women's History: The State of the Art in Atlantic Canada, Acadiensis 7, no. 1 (Fall 1977): 123.
} 
studies course together;", ${ }^{30}$ Vickers thought that anyone who "believed in advancing the status of women ... [could] call themselves a feminist" ${ }^{\text {"31 }}$; and Jackson didn't "believe in separation ... but I certainly believe[d] in women having the right to fully develop their potentials, and to be recognized for what they achieve." ${ }^{, 32}$ In keeping with later Canadian feminists such as Judy Rebick, all three were essentially frustrated with the systemic prejudice caused by "male power" that privileged men and disadvantaged women in the broader Canadian society, a social context that was being increasingly denounced nationally as being discriminatory. More specifically, they were committed to improving conditions for women on campus and making Carleton more "women friendly.",33

In 1970, the official report of the Royal Commission on the Status of Women was made public. According to Canadian sociologist Patricia Marchak, the fundamental assumption of the report was the "sex differences" were culturally created and "provide[d] differential opportunities and rewards to men and women." ${ }^{34}$ Specifically, in the areas of poverty and work, unsurprisingly the report confirmed that not only did female "breadwinners" made substantially less than their male counterparts $(\$ 2,536$ versus $\$ 5,821$ in 1967) and thus were more likely to be poor and that "women are often paid less for doing the same jobs as men and that so-called occupations are traditionally

${ }^{30}$ P. Finn, P. Finn and S. Gruda, oral history.

${ }^{31} \mathrm{~J}$. Vickers, oral history.

${ }^{32}$ S. Jackson, oral history.

${ }^{33} \mathrm{~J}$. Vickers, oral history. Vickers has a particular research interest in democracy and, in particular, the processes and circumstances through which this political form can become "women-friendly." She defines as "women-friendly" organizations or institutions in which women share "equally in making decisions" and argues that when women "'get in on the ground floor" of institutions they are more likely to increase their influence, thus making these organizations more "women-friendly." Jill Vickers, "In Search of Women-Friendly Democracy: Gender/Nation Relations in Modern Nation-States," 2006 Davidson Dunton Research Lecture, Carleton University, March 27, 2006.

${ }^{34}$ Patricia Marchak, "A Critical Review of the Status of Women Report," Canadian Review of Sociology / Revue Canadienne de Sociologie 9, no. 1 (February 1972): 73. 
underpaid. ${ }^{, 35}$ Underlying the commissioners' 167 recommendations were several broad goals, one of which was to ensure the "provision of equal opportunities and rewards" for Canadian men and women. ${ }^{36}$ By 1975, when Finn, Gruda, Jackson and Vickers were involved in unionization at Carleton, the Canadian academic community was releasing a series of similar "status of women" reports that included one for the Council of Ontario Universities and one for the Ontario Ministry of Colleges and Universities. ${ }^{37}$ In addition, at its annual business meeting in October that year, the Association of Universities and Colleges of Canada held special workshops on women in universities. ${ }^{38}$

The consensus of these reports echoed those of the Royal Commission five years earlier: the status of women on university campuses was poor, principally because they were found in the lowest paying jobs (either absolutely or relatively) and although many universities were engaged in activities to address these problems, "on many campuses women were discouraged by slow progress. ${ }^{, 39}$ Feminist activists at Carleton had a sense of urgency, not just because of the economic inequalities but also because of a persistent lack of respect from male colleagues. Vickers remembers clearly:

Most of the men on campus couldn't tell the difference, and they tended to treat everybody like a secretary. I say that on purpose, they treated everyone like a secretary. It was just like ... all the taxi drivers treat all women alike, and a lot of the men on campus treated all the women the same and there was a lot of ordering around. $^{40}$

${ }^{35}$ Benjamin Schlesinger, "Status of Women in Canada: Summary of Commission Recommendations", The Family Coordinator 20, no. 3 (July 1971): 255-56.

${ }^{36}$ Marchak, "A Critical Review."

${ }^{37}$ Laura Payton, The Status of Women in the Ontario Universities. A Report to the Council of Ontario Universities, June 1975, Office of the President fonds, PRES-43-4, Carleton University Corporate Archives, Ottawa, Ontario; Gail McIntyre and Janice Doherty, Women and Ontario Universities. A Report to the Ministry of Colleges and Universities, October 1975.

${ }^{38}$ Association of Universities and Colleges of Canada. Women and the Universities. La Femme et L'Université. Proceedings of the Annual Business Meeting and Conference, Association of Universities and Colleges of Canada, October 27-30, 1975, Ottawa.

${ }_{39}$ McIntyre and Doherty, Women and Ontario Universities, 2.

${ }^{40} \mathrm{~J}$. Vickers, oral history. 
Vickers did not view administrative or clerical work with contempt and in fact honoured support staff by making the commitment that she "would never cross one of their picket lines. ${ }^{, 41}$ Nonetheless, as a professor she did not want to be asked if she could type. Instead she wanted recognition of the legitimacy of her skills and credentials and to be treated as an equal by her colleagues. Likewise, Jackson's goal was to ensure that librarians, regardless of sex, received equitable compensation and Gruda and Finn wanted "equal pay for work of equal value." What this research has established is that although such concern for the status of women mobilized many to support unionization, Finn, Gruda and Vickers in particular recognized that in an atmosphere of "ordering around," gendered occupational inequities ultimately could not be the focus of the certification drives. Such concerns were not compatible with the status of university teaching and research or technically based jobs as masculine work. However, these women also realized that they could begin to address these issues in collective bargaining.

This is not the first analysis of the unionization of faculty at Carleton. It is, however, the first to examine in any depth, and simultaneously, the collective action of academic librarians and support staff at Carleton, or seemingly at any other Canadian university; these are the "invisible" workers still relatively hidden from history. ${ }^{42}$ In choosing to explore the role that status and gender played in this process, I found a conceptual framework that would be flexible enough, and not too much of a theoretical minefield, to allow for a meaningful comparison of these three occupational groups and account not just for differences but also for shared experiences. I grew up in an academic

\footnotetext{
41 Ibid.

${ }^{42}$ See for example, Judy Szekeres, "The Invisible Workers," Journal of Higher Education Policy and Management 26, no.1 (March 2004), 7-22; and Ann Kristine Pearson, “Disrespectin' Administrative Work: Can We Talk?," in Whose University is it Anyway? Power and Privilege on Gendered Terrain, eds. Anne Wagner, Sandra Acker and Kimine Mayuzumi (Toronto: Sumach Press, 2008): 127-39.
} 
home and yet my mother's constant word of caution was, "Don't forget dear, if you work for a living, you must be working class." I was primed to look for similarities of concerns and actions across occupational groups.

I have not pursued other aspects of the story that could prove equally interesting or illuminating. In particular, I deliberately do not address issues of ethnicity or race. In her oral history interview, Jill Vickers referred to pro-unionists as "the new sort" of professor that included women but also faculty members from visible minorities; future studies of academic unionization could explore the experiences of these members of the academic community—in all three groups. In addition, it would be interesting to compare the certification of unions at Anglophone universities such as Carleton to those at francophone institutions such as the bilingual University of Ottawa or L'Université de Montréal. ${ }^{43}$ The "phenomenon of generation" is also one that deserves fuller attention. Throughout the oral histories, professors, librarians and support staff frequently referred to the divisions between older and younger employees, and mentioned specifically that it was the younger workers who were the most eager for change. These comments are incorporated in this analysis but not analyzed systematically and, as German sociologist Karl Mannheim has written, "it is possible in general to draw a distinction between generations as mere collective facts on the one hand, and concrete social groups on the other." ${ }^{44}$

Finally, there is the question of place or community. Frequently, I am asked about the significance of Carleton's location in Ottawa, the Canadian national capital, in

\footnotetext{
${ }^{43}$ Jacques Rouillard, Apprivoiser le Syndicalisme en Milieu Universitaire. Histoire du Syndicat Général des Professeurs et Professeures de l'Université de Montréal (Montreal: Boréal, 2006).

${ }^{44}$ Karl Mannheim, "The Problem with Generations" Psychoanalytic Review 57, 3 (Fall 1970): 378404. See also Chapter 2 of this thesis where I refer to the work of American scholar Glen H. Elder, Jr. on life course, agency and historical change.
} 
relation to this example of collective action. My conclusion is that it was significant for support staff who compared themselves directly to employees of the federal civil service and for women like departmental administrator Evelyn Aldridge whose working lives were constrained by the federal policies regarding the employment of women. I have left unaddressed the connections for faculty and librarians, in part because neither the oral history interviews nor the documentary evidence suggest that their occupational status was linked to that of other academics or librarians in the city. Nonetheless, the notion of a community ended up figuring prominently faculty's descriptions of their identity, suggesting that perhaps this theme is more important than my initial research anticipated. Methodologically, the collection, transcription and interpretation of oral histories raise at least two important questions for future study: What is the role of body language and (i.e., non-verbal cues) and verbal cues other than the spoken word?; and how is authority shared between and interview and more than one interviewee? While I transcribed several of the video or audiotaped interviews, a hired transcriber produced the majority of the transcripts. In neither case were non-verbal forms of communication noted specifically — the emphasis was on the spoken word. In addition, when quoting from the transcripts, some data was edited out including repetitive phrases such as "you know" and information was introduced into the quotes to smooth out the sentences such as tense changes. Furthermore, I worked from the transcripts rather than reviewing, or watching multiple times, the film footage and yet undoubtedly I might have had more nuanced interpretations of certain responses had I done so.

Recognition of shared authority is critical to the use of oral histories. Typically, the literature cautions the interviewer to remember that trust is crucial to rich and 
revelatory historical storytelling and that it can be hard to nurture this bond if the interviewee is intimidated by the credentials or "academic status" of the researcher. In my case, the risk was reversed. As a student and a support staff employee of Carleton, I found that I had to manage feelings of awkwardness or intimidation in the face of questioning individuals with infinitely more institutional experience and academic expertise than myself. These feelings were exacerbated by the fact that I did almost all the interviews before having any real sense of my conceptual framework and so I was tentative and did not always follow-up or through on certain clues or comments that in hindsight I would have pursued. In reviewing the transcripts, it is clear that there were questions I did not ask but might have asked had I been feeling more confident—a phenomenon that cannot be unique to my research. In addition, I interviewed three couples, and also each of the six participants one-to-one. This was an effective strategy for balancing the change in dynamics that arise from sharing authority amongst three people but the challenges of group interviewing deserves greater attention.

For example, I did not initially identify Margaret McEown as a possible interviewee. However, in my first interview with her husband Don, he mentioned that she had worked at the university during the period I was studying, and had had direct contact with many Carleton support staff in her capacity as a personnel officer. When I asked her permission to do an interview with her, however, she was surprised and rather reticent about participating in my research. Not only is she is a modest woman, but it seemed that she was accustomed to perceiving Don as the family authority on Carleton history in the family. My initial interview with her was relatively short (one, rather than the two hours that most of the other interviews had lasted) and she seemed still to question the value of 
her own story. However, I asked to do another interview that would include both her and Don and in this subsequent session she was much more relaxed. My perception was that Don was very supportive of her experiences and that, as he encouraged her to participate, she remembered more and seemed to enjoy the process. In this case, marital dynamics were a very positive influence over the gathering of an oral history.

In 1971, E.P. Thompson suggested that "crass economic reductionism" in historical analysis was dangerous because it wiped out the "complexities of motive, behaviour, and function" which underlie social protests. ${ }^{45}$ Moreover, he proposed that every protest had a "legitimizing notion" a belief that people were "defending traditional rights or customs. ${ }^{{ }^{46}}$ Axel Howarth broadens this idea of the legitimizing belief to the generalized experience of moral disrespect. He proposes that individuals or groups will engage in social action when they believe that they have not been recognized in a socially acceptable way, or more importantly, when they have been treated unjustly. Professors, librarians and support staff at Carleton were motivated by immediate economic concerns but also by experiences of "moral disrespect." All three occupational groups believed that in some way their work had not been properly recognized; they were asserting their right to participate more fully in the decisions directly affecting their terms and conditions of work in order to ensure that they would be treated equitably in the future. Issues of inequality and injustice were particularly critical to women who were arguing for change not just on the basis of the value of their work but on their value as people.

The oral history interviews done for this research often ended with the interviewee's comments on the long-term outcomes of unionization at Carleton and

\footnotetext{
${ }^{45}$ E.P. Thompson, "The Moral Economy of the English Crowd," 78.

${ }^{46}$ Ibid.
} 
whether collective bargaining had resolved any of the core issues that led to unionization. The consensus amongst those who ventured an opinion, both men and women, is that the results have been mixed. Salaries and benefits have improved, but the balance of decision-making power still favours university administrators. In 2007, members of CUPE 2424 went on strike for the second time in the local's history and the core issue during that labour action was the same as it had been in 1976: respect. Anecdotally, CUPE negotiators were struck by the fact that university bargaining agents seem to have unsure of meaning of this idea; perhaps they were still mistaking pay raises for the fundamental recognition of the complexity and value of support staff work, as their predecessors had done. Moreover, a diverse team of employees and managers is currently working on a new job evaluation system for support staff positions; this process is lengthy but there is a possibility that the core beliefs about "know how," creativity and accountability needed to do various jobs will remain unchanged and the occupational hierarchy of the 1950s and 1960s will be preserved.

It is fitting that 1975 was also International Women's Year. In many ways, the unionization of Carleton professors, librarians and support staff represented a tribute to the efforts of women and men to gain a more equitable workplace. In particular, a debt is owed by successive generations of Carleton employees to the female leaders in each group. If Richard Van Loon construed later that the Carleton community had its "radicals but they were pretty tame radicals," he was mistaken in the case of these individuals who were "radical and uppity women": it is largely because they knew how to play their 
radical opinions strategically that Carleton University has become, in many ways, a better place to work than it was in the mid-1970s. ${ }^{47}$

${ }^{47}$ Judy Rebick refers to those who participated in Canada's women's movement as "radical uppity women.” Rebick, Ten Thousand Roses, xiii. 


\section{Appendix I}

\begin{tabular}{|c|c|c|}
\hline Name & Date of interview & Affiliation \\
\hline Aldridge, Evelyn & May 17,2011 & Admin. Staff \\
\hline Babcock, Ian & May 27, 2011 & Support Staff \\
\hline Briggs, Geoffrey & Email & Chief Librarian \\
\hline Brook, Andrew & April 17, 2011 & Faculty \\
\hline Clavette, Ken & April 18, 2011 & $\mathrm{~N} / \mathrm{A}$ \\
\hline Coll, David & May 18, 2011 & Faculty \\
\hline Coll, Margaret & May 18,2011 & Faculty Wife \\
\hline Empey, Elaine & October 3, 2011 & $\mathrm{~N} / \mathrm{A}$ \\
\hline Finn, Pat & $\begin{array}{l}\text { March 22, } 2011 \\
\text { March 5, } 2011 \text { (with S. } \\
\text { Gruda) }\end{array}$ & Support Staff \\
\hline Griffiths, Naomi & March 26, 2012 & Faculty \\
\hline Gruda, Sylvia & March 17, 0211 & Support Staff \\
\hline Gruda, Sylvia and Pat Finn & March 5, 2011 & Support Staff \\
\hline Jackson, Susan & $\begin{array}{l}\text { April 8, } 2011 \\
\text { April 24, } 2012 \text { (with F. } \\
\text { Montomgery) }\end{array}$ & Librarian \\
\hline Mair, Debra & March 19, 2011 & $\mathrm{~N} / \mathrm{A}$ \\
\hline McEown, Don & $\begin{array}{l}\text { March 14, 2011; April 21, } \\
2011\end{array}$ & Admin. \\
\hline McEown, Margaret & $\begin{array}{l}\text { April 21, 2011; July 12, } \\
2011\end{array}$ & Former Admin. \\
\hline McRae, Phyllis & April 16, 2011 & $\begin{array}{l}\text { CUSSA } \\
\text { Membership } \\
\text { Coordinator }\end{array}$ \\
\hline Montgomery, Frances & $\begin{array}{l}\text { June 10, 2011; April 24, } \\
2012 \text { (with S, } \\
\text { Jackson);July 27, } 2012\end{array}$ & Librarian \\
\hline Neatby, Blair & April 20, 2011 & Faculty \\
\hline Newton, Ann & July 10, 2011 & Library staff \\
\hline Scanlon, Joe & May 25, 2011 & Faculty \\
\hline Smith, Bette & June 11,2011 & Support Staff \\
\hline Swinton, Valerie & May 30, 2011 & Librarian \\
\hline Van Loon, Richard & April 5, 2011 & Former President \\
\hline Vickers, Jill & May 4, 2011 & Faculty \\
\hline
\end{tabular}




\section{Appendix II}

\section{Questions for Interviewees}

1) Biographical information

a) Tell me about your background

i) Your family

(1) Mother

(2) Father

(3) Birthplace

(4) Special remembrances of family life

(5) Cultural life (e.g., favourite books or pastimes while growing up)

ii) Your education

2) Work

a) Tell me about your work life

i) When did you start working and where?

ii) When did you first start working at Carleton University and what were you do?

iii) Which department were you working in?

iv) What job did you have at the time the union was starting to certify?

v) What was your annual salary or hourly wage?

vi) What was a normal work day life for you? Who did you work with/for?

vii) Did you have prior training or skills?

viii) Did you have family members working at the university?

ix) Did you work with women?

3) Administration and leadership at the university

a) Tell me about your relationship with the Board of Governors and President Oliver.

i) E.g., how would you describe the leadership style of the president, the chair of the Board and the bursar?

ii) Tell me about the senior administration's general relationship with faculty and staff.

iii) Tell me about the major financial issues facing the senior administration at this time.

4) Labour relations (general)

a) What would you say was the university management's attitude towards staff/faculty?

b) How did you get along with your manager?

c) How did staff get raises and changes to working conditions at the university?

How were disagreements between you and your supervisor/manager settled?

d) Talk to me about the relationship between unionization and university governance.

e) How would you define the collegial process?

f) Talk to me a bit about the impact of the unionization of support staff.

5) Unionization of support staff

a) Why do you think support staff unionized?

6) Do you have any thoughts to add? 
March 16, 2011

Title:

"If you work for a living, you must be working class." The formation of faculty and staff unions at Carleton University $1973-1977$

Subject Investigator: $\quad$ Martha Attridge Bufton Carleton University, Department of History (613) 520-2600, ext. 2985

Supervisor:

Dr. Dominique Marshall

Carleton University, Department of History

(613) 520-2600, ext. 2846

Date of Ethics clearance: February 25, 2011

Ethics clearance for

Data collection

Expires: $\quad$ May 31, 2012

Dear Sir or Madam,

My name is Martha Attridge Bufton and I am a Master's student in the Department of History at Carleton University. I am writing to invite you to participate in an oral history project which is being conducted under the supervision of Dr. Dominique Marshall.

This project is part of my thesis and the purpose of my research is to examine the unionization of faculty and staff at Carleton University. In particular, while the written history of the university refers to the unionization of faculty, there is no record of the unionization of staff which occurred during the same period (1973 to 1977). The goal of my research will address this gap with a focus on the role of women (women represented a significant proportion of the university's labour force in the early to mid-1970s) and I will compare the formation of the Carleton University Academic Staff Association (CUASA) with that of Carleton's support staff union CUPE 2424.

To collection the oral histories, I will be interviewing approximately 10 to 15 participants. Each individual will be asked a series of 15 to 21 questions that are related to the various 
themes that I will be exploring in my thesis such as the role of gender in the workplace. Where possible, a face-to-face recorded interview will be conducted and each interview is expected to take approximately three hours. These interviews will, with your consent (please indicate your preference below), to be video recorded and a follow-up interview may be conducted if any further clarification is necessary. The taped interviews will be transcribed by a student who has signed a confidentiality agreement.

I believe that there are no known risks, discomforts or inconveniences (physical, psychological, emotional, economic or social) for any participant associated with this research as individuals are being asked to reflect historically on their involvement in this issue and will not be asked to reveal any detailed and/or confidential information.

Participation in this study is voluntary and there are no personal benefits to participation. You may decline to answer any questions presented during the interview and withdraw from the project. Should you decide to withdraw, you must do so prior to August 1, 2011 and the information you have provided will be destroyed. Anonymity will not be offered and you will be quoted, unless otherwise requested, and identified in the final thesis.

Data collection during this study will be retained indefinitely, in a locked office to which will be accessible only researchers associated with this. Once completed, this thesis will be published and a copy will be held in the Carleton University Library and available to participants. There are no benefits to you arising from participation in this project

This study has been reviewed and received ethics clearance through the Carleton University Research Ethics Board. If you have any comments or concerns resulting from your participation in this study, please contact me or my supervisor Dr. Dominique Marshall (contact information below). In addition, you may contact Professor Antonio Gualtieri, the chair of the Carleton University Research Ethics Board, at:

\section{Research Ethics Board}

Carleton University Research Office

Carleton University

1325 Dunton Tower

1125 Colonel By Drive

Ottawa, ON K1S 5B6

Tel: 613-520-2517

ethics@carleton.ca 
Thank you for your assistance in this project.

Yours sincerely,

(Signature)

Martha Attridge Bufton

Master's student, Department of History

Tel: 613-520-2600, ext. 2985

martha attridge bufton@carleton.ca
(Signature)

Dr. Dominique Marshall

Supervisor, Department of History

Tel: 613-520-2600, ext. 2846

dominique_marshall@carleton.ca

I agree to be video recorded. 


\section{INFORMED CONSENT STATEMENT}

Title: "If you work for a living, you must be working class." The formation of faculty and staff unions at Carleton University, 1973-1977

\section{Ethics clearance date:}

Expiry date for collecting data: 31 May 2011

I , have voluntarily agreed to participate

in an interview with Martha Attridge Bufton, a master's student in the Department of History at Carleton University, Ottawa, on the unionization of faculty and staff at Carleton during the period 1973 to 1977 . The research will address a gap in the university's history of staff unionization.

I understand the interview will take approximately three hours and, with my consent, will be videotaped. The researcher may contact me with follow-up questions for clarification if necessary.

There is no known risk to me for my participation but I retain the right to not answer questions and to end the interview at any time. Should I withdraw from the study I will do so before June 1,201o as after that time the researcher will be unable to retract my interview from the information she has collected and is analyzing. Should I withdraw from the study all notes and materials from my interview will be destroyed.

There is no benefit to me from my participation in this study.

I understand that I will not be anonymous and that I will be quoted and identified. I retain the right to ask that certain comments and opinions not be used or attributed to me.

If I have any questions I may speak with the researcher or her supervisor Dr. Dominique Marshall.

I understand that this project has been reviewed and cleared by the Carleton University Research Ethics Board (CUREB) and concerns and questions may be directed to the CUREB chair. 
I agree to take part in this study as a research participant.

Participant's Signature

Date

Researcher's Signature

Date

Research contact information:

Martha Attridge Bufton

Department of History

Carleton University

Ottawa, ON K1S 5B6

martha_attridge_bufton@carleton.ca

Research contact information:

Dr. Dominique Marshall

Department of History

Carleton University

Ottawa, ON K1S 5B6, ext. 2846

dominique_marshall@carleton.ca

\section{Research Ethics Board:}

Professor Antionio Gualtieri, Chair

Research Ethics Board

Carleton University

1325 Dunton Tower

1125 Colonel By Drive

Ottawa, ON K1S 5B6

Tel: 613-520-2517

ethics@,carleton.ca 
Carleton

Canada's Capital University
Carleton University Research

Office

Research Ethics Board 1325 Dunton Tower

1125 Colonel By Drive

Ottawa, ON K1S 5B6 Canada

Tel: $613-520-2517$

ethics@carleton.ca

\section{Ethics Clearance Form}

This is to certify that the Carleton University Research Ethics Board has examined the application for ethical clearance. The REB found the research project to meet appropriate ethical standards as outlined in the Tri-Council Policy Statement: Ethical Conduct for Research Involving Humans, $2^{\text {nd }}$ edition and, the Carleton University Policies and Procedures for the Ethical Conduct of Research.

$\square$ New clearance

$X$ Renewal of original clearance
Original date of clearance:

25 February 2011
Date of renewal

Researcher

Status

Supervisor

Project number

Title of project
24 May 2012

Martha Attridge-Bufton

M.A. student, Department of History

Professor Dominique Marshall, Department of History

11-1097

"If you work for a living, you must be working class:" The formation of faculty and staff unions at Carleton University, 1973-1977

Clearance expires: 31 May 2014

All researchers are governed by the following conditions:

Annual Status Report: You are required to submit an Annual Status Report to either renew clearance or close the file. Failure to submit the Annual Status Report will result in the immediate suspension of the project. Funded projects will have accounts suspended until the report is submitted and approved. 
Changes to the project: Any changes to the project must be submitted to the Carleton University Research Ethics Board for approval. All changes must be approved prior to the continuance of the research.

Adverse events: Should any participant suffer adversely from their participation in the project you are required to report the matter to the Carleton University Research Ethics Board. You must submit a written record of the event and indicate what steps you have taken to resolve the situation.

Suspension or termination of clearance: Failure to conduct the research in accordance with the principles of the Tri-Council Policy Statement: Ethical Conduct for Research Involving Humans $2^{\text {nd }}$ edition and the Carleton University Policies and Procedures for the Ethical Conduct of Research may result in the suspension or termination of the research project.

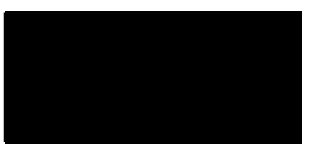

Andy Adler, Chair Carleton University Research Ethics Board Board

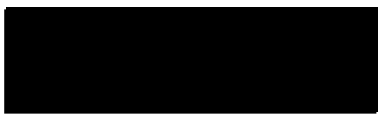

Louise Heslop, Vice-Chair Carleton University Research Ethics 


\title{
Bibliography
}

\section{Primary sources}

\author{
Manuscripts \\ Archives of Ontario \\ Dunham, Mabel. Library Work as a Profession for Canadian Women. Presidential \\ address. Ontario Library Association Fonds F1195, MU 2246, B287359. \\ Toronto, Ontario. 1920.
}

\section{Carleton University Corporate Archives}

Carleton University Academic Staff Association fonds

Carleton University Support Staff Association fonds

Board of Governors fonds

Office of the President fonds

Office of the Vice President (Planning and Development) fonds

\section{Carleton University Library Archives}

Blair Neatby fonds

Don McEown fonds

Public Relations and Information Services fonds

The Carleton

The Charlatan

This Weeks Times Two

University Communications fonds

\section{Carleton University Office of Institutional Research and Planning Carleton University Data Books}

\section{Correspondence with the author}

Bannister, John. E-mail to the author. November 21, 2013.

Briggs, Geoffrey. E-mail to the author. November 1, 2011.

Cristiano, Tony. E-mail to author, November 25, 2013.

Gruda, Sylvia. E-mail to the author, November 192013.

Hubbard, Katherine. E-mail to the author. April 25, 2012.

Jackson, Susan. E-mail to the author. November 15, 2012.

Millar, Elizabeth. E-mail to the author. November 22, 2013.

\section{Documents in the possession of the author}

Association of Professional Librarians of Carleton University. Collective Bargaining Committee. Report. February 1975.

Statement. February 5, 1975

Association of Professional Librarians of Carleton University. Committee for Conditions of Employment and Work. Submission on Conditions of Employment and Work to the Council and Members of the Association of Professional Librarians of Carleton University. May 1975. 
Association of Professional Librarians of Carleton University. Council. Memo to all

Professional Librarians from APLCU Council. December 6, 1974

Minutes. 1974-1976.

-Notice of General Meeting of APLCU. n.d.

Brearley, Neil and Valerie McDougall. Librarians and CUASA: A Statement to the

Sub-Committee Exploring the Membership of Librarians in CUASA. 1975.

Brook, J.A., B. Wand, V. McDougall, and N. Brearley. CUASA Report of the SubCommittee on Membership of Librarians. (n.d.).

Campbell, Allen and Irene Dawson, eds. The Library Technician at Work: Theory and

Practice. Proceedings of the Workshop held at Lakehead University, Thunder

Bay, Ontario, May 8-9, 1970. Thunder Bay: Lakehead University, 1970.

Canadian Union of Public Employees. Background Material Prepared For the Institute of Professional Librarians of Ontario Panel on Job Security for Librarians. 1975.

Carleton College. Convocation Booklet, May 18, 1956.

Carleton University. Carleton University Data Book 1974-75. Ottawa: Carleton University, 1975.

Carleton University Data Book 1977-78. Ottawa: Carleton

University, 1975.

Collective Agreement between Carleton University and Carleton

University Academic Staff Association, December 1, 1975 to April 30, 1978.

Collective Agreement between Carleton University and Carleton University Academic Staff Association, December 1, 1975. Ottawa: Carleton University, 1975.

Evans, Cal. "Report on York Meeting." (n.d.)

Evans, Calvin D. and Tom Eadie. AALO. Elaboration of the Fourteen Points in Answering the Question "What is it we want as University Librarians? (n.d.)

Finn (Chartier). P.A. Report on the Status of Women at Carleton University (Students and Support Staff). (n.d.)

Foss, Martin. Memorandum to Geoffrey Briggs. July 15, 1974.

History of CUPE 2424, n.d., 2-3, in the author's possession.

MacRae, Phyllis. Field Placement Report. May 31, 1976.

McDougall, Valerie. Letter to Professor R.H. Crowther, Canadian Association of

University Teachers.” May 9, 1974.

Report on IPLO Workshop: Negotiating Options for Librarians. (n.d.)

Professional Staff Committee. Carleton University Library. Notice of Meeting. (n.d.)

- York University Meeting of University and College Librarians in Ontario. Ottawa, September, 1974.

Vickers, Jill. Letter to Martin Foss and Valerie McDougall. October 10, 1974.

Note to librarians regarding meeting with CUASA President. Wednesday, October 23, 1974.

\section{Interviews}

Aldridge, Evelyn. Interview with the author. May 17, 2011.

Brook, Andrew. Interview with the author. April 17, 2011.

Coll, David. Interview with the author. May 18, 2011.

Coll, Margaret. Interview with the author. May 18, 2011.

Finn. Pat. Interview with the author. March 22, 2011. 
Interview with the author and Sylvia Gruda, March 5, 2011.

Gruda, Sylvia. Interview with the author. March 17, 2011.

Interview with the author and Pat Finn, March 5, 2011.

Griffiths, Naomi. Interview with the author. March 26, 2012.

Jackson, Susan. Interview with the author. April 8, 2011.

Interview with F. Montgomery and the author, April 24, 2011..

McEown, Don. Interview with the author. March 14, 2011.

McEown, Margaret. Interview with the author.

McRae, Phyllis. Interview with the author. May 4, 2011.

Montgomery, Frances. Interview with the author. June 10, 2011.

Interview with S. Jackson and the author. April 24, 2011.

Interview with the author. July 27, 2012.

Neatby, Blair. Interview with the author. April 20, 2011.

Newton, Ann. Interview with the author. July 6, 2011.

Montgomery, Frances. Interview with the author. June 11, 2011.

Scanlon, Joseph. May 25, 2011.

Smith, Bette. June 11, 2011.

Swinton, Valerie. Interview with the author. May 30, 2011.

Van Loon, Rick. Interview with the author. April 5, 2011.

Vickers, Jill. Interview with the author. May 4, 2011.

\section{Printed sources}

\section{Government documents}

\section{Canada}

Boyd, Monica. Canadian Attitudes Toward Women: Thirty Years of Change, Women's Bureau, Labour Canada. Ottawa: Minister of Labour, Government of Canada, 1974.

Canada. Survey of Libraries in Canada 1931. Ottawa: Dominion Bureau of Statistics, 1931.

-Survey of Libraries in Canada 1935. Ottawa: 1933.

-Survey of Canadian Libraries. Being Part III of the Biennial Survey of Education in Canada, 1936-1938. Ottawa: J.O. Patenaude, I.S.O. 1939.

Libraries in Canada, 1944-1946. Being Part III of the Biennial Survey of

Education in Canada, 1944-1946. Ottawa: Edmond Cloutier, Queen's Printer and Controller of the Stationary, 1950.

-Survey of Libraries 1948-1950. Part III of the Biennial Survey of Education in Canada, 1948-1950. Ottawa: Edmond Cloutier, Queen's Printer and Controller of the Stationary, 1952.

Survey of Higher Education, 1950-1952, (Part II of the Biennial Survey of

Education in Canada, 1950-1952). Ottawa: Edmond Cloutier, Queen's Printer and Controller of Stationary, 1954.

Canada. Task Force on Labour Relations. Canadian Industrial Relations. The Report of the Task Force on Labour Relations. Ottawa: Privy Council Office, 1968.

Denton, Frank T. and Sylvia Ostry, Historical Estimates of the Canadian Labour Force 
Ottawa: Dominion Bureau of Statistics, 1967.

Eaton, J.K. Union Growth in Canada in the Sixties. Labour Canada, Economics and Research Branch. Ottawa: Information Canada, 1976.

Ostry, Sylvia. The Occupational Composition of the Canadian Labour Force. One in a Series of Labour Force Studies in the 1961 Census Monograph Programme. Ottawa: Dominion Bureau of Statistics, 1967.

Royal Commission on Canada's Economic Prospects. Preliminary Report. Ottawa: December, 1956.

Royal Commission on the Status of Women in Canada. Report of the Royal Commission on the Status of Women in Canada. Ottawa: The Commission, 1970.

Statistics Canada. Education in Canada 1973. A Statistical Review for the Period 196061 to 1970-71. Ottawa: Information Canada, 1973.

\section{Ontario}

An Act to Amend the Labour Relations Act, R.S.O. c76.

Carleton University Act, SO 1952, c117.

Labour Relations Act, RSO 1970, c232.

Ontario Labour Relations Board. Certificate 1455-R Carleton University Support Staff

Association (March 4, 1976), Carleton University Support Staff Association

(Applicant) $v$ Carleton University (Respondent) v Group of Employees (Objectors).

Toronto: 1976.

-Report. Applications Disposed by the Ontario Labour Relations Board during March 1976. Toronto: March, 1976.

\section{Addresses, guides, reports}

Archibald, Kathleen. Sex and the Public Service. Ottawa: Public Service Commission of Canada, 1970.

Association of Universities and Colleges of Canada. Women and the Universities. La Femme et L'université. Proceedings of the Annual Business Meeting and Conference, Association of Universities and Colleges of Canada, October 27-30, 1975. Ottawa, Ontario.

Duff, James and Robert O. Berdahl. University Government in Canada. Report of a Commission Sponsored by the Canadian Association of University Teachers and the Association of Universities and Colleges of Canada. Toronto: University of Toronto Press, 1966.

Bureau of Public Personnel Administration. Proposed Classification and Compensation Plans for Library Positions. Report of the Bureau of Public Personnel Administration to the Committee on the Classification of Library Personnel of the American Library Association. Washington, D.C.: Bureau of Public Personnel Administration, 1927.

Canadian Association of College and University Libraries. Guide to Canadian University Library Standards. Report of the University Library Standards Committee of the Canadian Association of College and University Libraries $196-1964.1965$.

Canadian Association of University Teachers. C.A.U.T. Handbook. Ottawa: CAUT, 1971. 
Canadian Association of University Teachers. Submission to the Royal Commission on the Status of Women. 1967.

Canadian Association of University Teachers. The University Teacher and the Crisis in Higher Education in Canada. A Brief Presented to the Royal Commission by the Canadian Association of University Teachers. Ottawa: 1956.

Canadian Association of University Teachers. A Comparison of Men's and Women's Salaries and Employment Fringe Benefits in the Academic Profession. 1967.

Canadian Library Association. Salary Scales Recommended for Public Libraries, College and University Libraries in Canada. Victoria: Canadian Library Association, 1957.

Hardy, E.A. "An Outline Programme of the Work of the Ontario Library Association. A Paper Read at the First Annual Meeting, 1901." Reprinted in The Ontario Library Association. An Historical Sketch. 1900-1921. Toronto: University of Toronto Press, 1926.

Presidential Address. The Proceedings of the Ontario Library Association, Tenth Annual Meeting, March 28 and 29, 1910. Toronto: Legislative Assembly, 1910.

Hurtubise Rene and Donald C. Rowat. The University, Society and Government. The Report of the Commission on the Relations Between Universities and Governments. Ottawa: University of Ottawa Press, 1970.

McIntyre, Gail and Janice Doherty. Women and Ontario Universities. A Report to the Ministry of Colleges and Universities. October 1975.

Payton, Laura. The Status of Women in the Ontario Universities. A Report to the Council of Ontario Universities, June 1975.

Professional Staff Committee. Carleton University Library. "York University Meeting of University and College Librarians in Ontario." Ottawa, September, 1974.

Systems and Procedures Exchange Centre. Association of Research Libraries. Paraprofessionals in ARL Libraries. SPEC Flyer, 21. 1975.Working Women,

National Association of Office Workers, Becoming a Priority: The Status of University and College Office Staff. National Survey and Analysis of Office Employment in Higher Education. Cleveland, Boston, Washington, D.C.: National Association of Office Workers.

\section{Articles, books, conference proceedings, editorials and papers}

Beckman, Margaret. "Implications for Academic Libraries." In Collective Bargaining in Libraries (Papers Presented at the Allerton Park Institute 1974), edited by F.A. Schlipf, 122-45. Accessed November 30, 2013. https://www.ideals.illinois.edu/handle/2142/499.

Berelson, Bernard. "Library Unionization." The Library Quarterly 9 no. 4 (October 1939): 477-510.

Bishop, Olga. B. The Use of Professional Staff in Libraries: A review 1923-1971, CLA Occasional Paper No. 81. Ottawa: Canadian Library Association, 1973.

Bishop, William Warner. "The American Library Association. II. Fragments of Autobiography." The Library Quarterly 21, no. 1 (January 1951): 35-41.

Bureau of Public Personnel Administration. Proposed Classification and Compensation Plans for Library Positions. Report of the Bureau of Public Personnel 
Administration to the Committee on the Classification of Library Personnel of the American Library Association. Washington, D.C.: Bureau of Public Personnel Administration, 1927.

Cheda, Sherrill. "That Special Little Mechanism." Canadian Library Journal 31, no. 5 (1974): 422-32.

Dewey, Melvil. "The Profession." The American Library Journal 1, no. 1 (September 1876): 5-6.

"Women in Libraries: How They are Handicapped." In The Role of Women in Librarianship 1876-1976: The Entry, Advancement, and Struggle for Equalization in One Profession, edited by Kathleen Weibel and Kathleen M. Heim, 10-12. Phoenix: Oryx Press, 1979.

Downs, Robert B. Resources of Canadian Academic Research Libraries. Ottawa: Association of Universities and Colleges of Canada, 1967.

Editorial. American Library Journal 1, no. 1 (1876): 12.

Evans, Calvin D. "Librarians and CAUT: Historical Overview and Future Directions." CAUT Bulletin, Special Report (March 1976): 12-13.

Gifford, Hilda. "Function and the Library Building." Royal Architectural Institute of Canada Journal 36, no. 4 (1959): 104-05.

Henry, W.E. "Recruiting for College and University Libraries." Bulletin of the American Library Association, Papers and Proceedings of the Forty-Fourth Annual Meeting of the American Library Association 16, no. 4 (July 1922): 124-25.

Hughesman, Jack. Union Representative Looks at Librarians. Canadian Library Association Conference 1973 Proceedings. 1973.

Kent, Charles Deane. "What is a Professional?" Ontario Library Review, (May 1957), 89-91.

MacKenzie, N.A.M. and D.C. Rowat, "The Federal Government and Higher Education in Canada." The Canadian Journal of Economics and Political Science 16, no. 3 (August 1950): 353-70.

Muir, Jim. "Spacious Library to Open Soon." The Carleton 10 (Thursday, December 7, 1950): 6-7.

Obituary. "Dr. Melvil Dewey Dead in Florida: Noted Educator, Library Expert and Founder of Lake Placid Club Stricken at 80." New York Times (December 27, 1931): 36. Accessed November 30, 2013. http://bit.ly/18rXxpH.

Rowat, Donald C. "Faculty Participation in Canadian University Government." AAUP Bulletin 43, no. 3 (September 1957): 461-76. " "The Government of Canadian Universities." Culture. A Quarterly Review. Religious and Secular Sciences in Canada 17 (1956), 268-283 and 364-378.

Salter, F.M. "The University in a Democratic Age." Canadian Association of University Teachers Bulletin Session 2, no. 1 (1953-54): 1-10.

Shorter, Edward. "The Dark side of The Sexual Revolution. Left-Behind Women." Chatelaine, March 1977, 56.

Smith, Bette "Left-behind Women." The Last Word is Yours (letters to the editor). Chatelaine, April 1977, 5.

Statement on Faculty Status of College and University Librarians." College and Research Libraries 35, no. 2: 26 (1974): 26. 
Students of the School. "The Training School for Librarianship." Ontario Library Review II, no. 2: 53-57.

The Ontario Library Association. The Ontario Library Association. An Historical Sketch, 1900-1926. Toronto: University of Toronto Press, 1926.

Trotter, Bernard, David L. McQueen and Bertrand L. Hansen "The Ten O'clock Scholar? What a Professor Does for His Pay." CAUT Bulletin ACPU January 1973: 4-9.

Vickers, Jill McCalla, and June Adam. but can you type? Canadian Universities and the Status of Women. Toronto: Clarke, Irwin \& Company, 1977.

\section{Secondary sources}

Articles, book chapters, editorials and papers

Altman, Morris and Louise Lamontagne. "On the Natural Intelligence of Women in a World of Constrained Choice: How the Feminization of Clerical Work Contributed to Gender Pay Equality in Early Twentieth Century Canada." Journal of Economic Issues 4 (December 2003), $1045-1074$

Anstead, Christopher and Ivor F. Goodson, "Subject Status and Curriculum Change: Commercial Education in London, Ontario, 1920-1940." Paedagogica Historica 29, no. 2 (1993): 459-81.

Acker, Joan. "Hierarchies, Jobs, Bodies: A Theory of Gendered Organizations." Gender \& Society 4, (1990): 139-58.

Adams, Tracey L. "Professional Regulation in Canada: Past and Present." Canadian Issues (Spring 2007), 14-16.

Anderson, Linda L. "On Strike against Yale University." Frontiers: A Journal of Women Studies 8, no. 3, Tenth Anniversary Issue: The Women's Studies Movement: A Decade Inside the Academy (1986): 26-32.

Asheim, Lester. "Bernard Berelson (1912-1979)." The Library Quarterly 50, no. 4 (October 1980): 407-09.

Barley, Stephen R. and Julian E. Orr, "Introduction: The Neglected Workforce." In Between Craft and Science. Technical Work in U.S. Settings, edited by Stephen R. Barley and Julian E. Orr, 1-19. Ithaca and London: ILR Press, an imprint of Cornell University Press, 1997.

Barry, Kathleen M. "Too Glamorous to Be Considered Workers": Flight Attendants and Pink-Collar Activism in Mid-Twentieth-Century America." Labor: Studies in Working Class History of the America 3, no. 3 (Fall 2006): 119-38.

Bellak, Alvin. "Specific Job Evaluation Systems: The Hay Guide Chart-Profile Method." In Handbook of Wage and Salary Administration, edited by Milton L. Rock. New York: McGraw-Hill, 1984.

Belisle, Donica. "Exploring Postwar Consumption: The Campaign to Unionize Eaton's in Toronto, 1948-1952." The Canadian Historical Review 86, no. 4 (December 2005): 641-72.

Benson, John. "Canadian Labour History." Bulletin-Society for the Study of Labour History 51, no. 1 (1986): 18-24.

Bird, Patricia. "Hamilton Working Women in the Period of the Great Depression." Atlantis, 8, no. 2 (1982): 125-36.

Bodeije, H.R. "And Then There Were Three: Self-Presentational Styles and the Presence of the Partner as a Third Person in the Interview." Field Methods 16, no. 1, 
(February. 2004): 3-22.

Bow, Eric. "Interrupted Careers: The Married Woman as Librarian." Ontario Library Review 56, no. 2 (June 1972): 76-8.

Boyd, Monica. "Feminizing Paid Work." Current Sociology 45, no. 2 (1997): 49-73;

Boyer, Kate "“"Neither forget nor remember your sex": Sexual Politics in the Early

Twentieth-century Canadian Office.” Journal of Historical Geography 29, no. 2, (2004): 212-29.

Brand, Barbara. "Pratt Institute Library School: The Perils of Professionalism." In Reclaiming the American Library Past: Writing the Women. edited by Suzanne Hildebrand, 251-78. Norwood, New Jersey: Ablex Publishing Company, 1996.

Briskin, Linda. "Women and Unions in Canada: A Statistical Overview." In Union Sisters. Women in the Labour Movement, edited by Linda Briskin and Lynda Yanz, 28-43. Toronto: The Women's Press, 1983.

Bruce, Lorne. "Professionalization, Gender and Librarianship in Ontario, 1920-1975." Library and Information History 28 no. 2 (2012): 117-34.

Burke, Peter. "Overture. The New History: Its Past and its Future." In New Perspectives on Historical Writing, $2^{\text {nd }}$ ed., edited by Peter Burke, 1-24. University Park, Pennsylvania: Pennsylvania State University Press: 2001.

Cheda, Sherrill, Linda Fischer, Mary Ann Wasylycia-Coe, and Phyllis Yaffe. "Salary Differentials of Female and Male Librarians in Canada." Emergency Librarian 5 no. 3 (January/February 1978): 3-13.

Cohn, Samuel Ross. "Clerical Labour Intensity and the Feminization of Clerical Labor in Great Britain, 1857-1937." Social Forces 63, no. 4 (1985): 1060-68.

Coole, Diana. "Is Class a Difference That Makes a Difference?" Radical Philosophy 77 (May/June 1999): 17-25.

Coulter, Kendra. "Unionizing Retail: Lessons From Young Women's Grassroots Organizing in the Greater Toronto Area in the 1990s." Labour / Le Travail, 67 (Spring 2011): 77-93.

Crompton, Rosemary. "Approaches to the Study of White Collar Unionism." Sociology 10, no. 3, (September 1976): 40-26.

"Gender, Status and Professionalism," Sociology 21, no. 3 (Aug. 1987): 413-28.

Cutler III, William. "Accuracy in Oral History Interviewing." Reprinted in Oral History. An Interdisciplinary Anthology, edited by David K. Dunaway and Willa K. Baum, 99-106. Walnut Creek: AltaMira, 1996.

Dewalt, Bryan, "Men, Women and Machines: Time Management and Machine Dictation in the Modern Office." Material History Review 52 (Fall 2000), 16-32.

Dempsey, Hugh A., "Confessions of a Calgary Stenographer." Alberta History 36, no. 2 (Spring 1988): 1-15.

Dunlap, Connie R. "Organizational Patterns of Academic Libraries, 1876-1976." College and Research Libraries (September 1976): 395-407.

England, Kim and Kate Boyer, "Women's Work: The Feminization and Shifting Meanings of Clerical Work." Journal of Social History 43, no. 2 (2009): 307-40.

Elder, Jr. Glen H. "Age Differentiation and the Life Course." Annual Review of Sociology"1 (1975): 165-90.

Entman, Robert M. "Framing: Toward Clarification of a Fractured Paradigm." Journal of 
Communication 43, no. 4 (December 1993): 51-8.

Flanagan, Leo Nelson. "Sleeping Giant Awakes: The Unionization of Library Support Staffs." Wilson Library-Bulletin 48, no. 6 (February 1974): 491-99.

Frager. Ruth. "No Proper Deal: Women Workers and the Canadian Labour Movement, 1870-1940." In Women in the Labour Movement, edited by Linda Briskin and Lynda Yanz, 4-64. Brampton: Women's Press, 1983.

Fudge, Judy and Erick Tucker. "Pluralism or Fragmentation?: The Twentieth-Century Employment Law Regime in Canada." Labour / Le Travail 46, Special Millennium Issue (Fall 2000): 251-306.

Garrison, Dee. "The Tender Technicians: The Feminization of Public Librarianship, 1876-1905." Journal of Social History 6, no. 2 (Winter 72/73): 131-59.

Garry, Carl G. "The Unionization of the Profession." In Canadian Libraries in Their Changing Times, edited by Lorraine Spencer Garry and Carl Garry, 499-519.

Toronto: York University, The Centre for Continuing Education, 1977.

Gentile, Patrizia. "Government Girls" and "Ottawa Men": Cold War Management of

Gender Relations in the Civil Service." In Whose National Security? Canadian

State Surveillance and the Creation of Enemies, edited by Gary Kinsman, Dieter

K. Buse and Mercedes Steedman, 131-41. Toronto: Between the Lines, 2000.

Goode, William J. "The Librarian: From Occupation to Profession?" The Library

Quarterly 31, no. 4 (October 1961), 306-20.

Gregory Sansbury, Gail. "Now What's the Matter with you Girls?' Clerical Workers Organize." Radical America 14, no. 6 (1980): 67-75.

Grele, Ron. "Can Anyone over Thirty be Trusted: A Friendly Critique of Oral History." The Oral History Review 6 (1978): 36-44.

Guard, Julie. "Fair Play or Fair Pay? Gender Relations, Class Consciousness, and Union Solidarity in the Canadian UE" Labour / Le Travail 37 (Spring 1996): 149-77.

Hagwood, Patricia. "Newsletters." In International Encyclopedia of Communications, edited by Erik Barnouw, 178. New York, Oxford: Oxford University Press, 1989.

Harris, Robin. "The Universities of Canada," Commonwealth Universities Yearbook. Association of Commonwealth Universities, 1975.

Heron. Craig. "Harold, Marg and the Boys: The Relevance of Class in Canadian History." Journal of the Canadian Historical Association/ Revue de la Société Historique du Canada 20, no. 1, 2009: 1-56.

Hildenbrand, Suzanne. "Librarian Feminism and Library Women's History: Activism and Scholarship, Equity and Culture." Libraries and Culture 35, no. 1 (Winter 2000): 51-65.

Hitlin, Steven and Glen H. Elder, Jr. "Time, Self, and the Curiously Abstract Concept of Agency." Sociological Theory 25, no. 2 (June 2007): 170-91.

Hoffman, Alice. "Reliability and Validity in Oral History." Reprinted in Oral History. An Interdisciplinary Anthology, 2nd ed., edited by David K. Dunaway and Willa K. Baum, 87-93. Walnut Creek, London, New Delhi: Altamira Press, 1996.

Hulse, Elizabeth. "The Development of Libraries in Ontario and Their Relations with the National Library of Canada." In The National Library of Canada and Canadian Libraries: Essays in Honour of Guy Sylvestre, edited. Jean-Rémi Brault, Gwynneth Evans and Richard Paré, 79-110. Ottawa: Canadian Library 
Association, 1996).

Hurd, Richard W. "Learning from Clerical Unions: Two Cases of Organizing Success." Labor Studies Journal 14, no. 1 (Spring 1989): 30-51.

Husak, Alan "First NDP President a 'Boundless Optimist'." The Ottawa Citizen. October 2, 2004: E3.

Hyman, Richard. "White-Collar Workers and Theories of Class." In The New Working Class? White-Collar Workers and Their Organizations. A Reader, edited by Richard Hyman and Robert Price, 3-45. London and Basingstoke: The MacMillan Press Ltd., 1983. "Will the real Richard Hyman please stand up?" Capital \& Class 36, no. 1: 15164, doi: 10.1177/0309816811431875c\&c.sagepub.com.

Joch Robinson, Gertrude. "The Media and Social Change: 30 Years of Magazine Coverage of Women and Work (1950-1977)." Atlantis 8, no. 2 (Spring 1983), $87-111$.

Jackson, Nancy S. and Jane S. Gaskell, "White-Collar Vocationalism: The Rise of Commercial Education in Ontario and British Columbia 1870-1920." Curriculum Inquiry 17, no. 2 (Summer 1987): 177-201.

Johnson, Leo. "The Political Economy of Ontario Women in the Nineteenth Century." In Women at Work, 1850-1930, edited by Janice Acton, Penny Goldsmith, Bonnie

Shepard, 13-32. Toronto: Canadian Women's Educational Press, 1974).

Jones, Glen A., Theresa Shanahan and Paul Goyan. "Traditional Governance StructuresCurrent Policy Pressures: The Academic Senate and Canadian Universities," Tertiary Education and Management 8, no. 1: 135-48.

Kassalow, Everett M. "Canadian and U.S. White-Collar Union Increases." Monthly Labor Review, (July 1968): 41-45.

Kealey, Gregory and Bryan Palmer, "The Bonds of Unity: The Knights of Labor in Ontario, 1880-1900." Social History/Histoire Sociale 14, no. 28 (November 1981): $369-411$.

Kessler-Harris, Alice "Where are all the Organized Women Workers?" Feminist Studies 3, no. 1/2 (Autumn 1975): 92-110.

Kitzinger, Jenny. "Framing and Frame Analysis." In Media Studies. Key Issues and Debates, edited by Eoin Devereux, 134-61. Los Angeles, London, New Dehli, Singapore: Sage Publications, 2007.

Kleingartner, Archie. "The Organization of White-Collar Workers." British Journal of Industrial Relations 6, no. 1 (March 1968): 79-93

Klement, Susan. "Feminism and Professionalism in Librarianship. An Interview with Sherrill Cheda." Canadian Library Journal 31 (November-December 1974): 52028.

Lowe, Graham S. "Class, Job and Gender in the Canadian Office." In Canadian Working Class History, 2nd edition, eds. Laurel Sefton MacDowell and Ian Radforth, 380404. Toronto: Canadian Scholars' Press Inc., 2000.

Lower, A.R.M. “The Canadian University: Time for a New Deal." Queen's Quarterly 62, (Fall 1955): 243-256.

Linnell, Greg. "The Institute of Professional Librarians in Ontario: On the History 
and Historiography of a Professional Association.” 2008. Accessed July 1, 2012. http://eprints.rclis.org/12214/.

Mac Con Iomaire, Mairtin. "Hidden Voices from the Culinary Past: Oral History as a Tool for Culinary Historians." In Food and Language: Proceedings of the Oxford Symposium of Food and Cookery, 217-26. Totnes: Prospect Books, 2010.

Mackinnon, F. "The University: Community or Utility." Canadian Public Administration 3, no. 4 (December 1960): 337-43.

Makahonuk, Glen. "In Union is Strength": The University of Saskatchewan Employees' Union Strike of 1974." Saskatchewan History 48, no. 1 (Spring 1996): 30-43.

Marchak, Patricia. "A Critical Review of the Status of Women Report." Canadian Review of Sociology / Revue Canadienne de Sociologic 9, no. 1 (February 1972): 73-85.

Mannheim, Karl. “The Problem with Generations.” Psychoanalytic Review 57, no. 3 (Fall 1970), 378-404.

McDermott, Patricia. "Pay Equity in Canada: Assessing the Commitment to Reducing the Wage Gap." In Just Wages. Feminist Assessment of Pay Equity, edited by Judy Fudge and Patricia McDermott, 21-32. Toronto, Buffalo, London: University of Toronto Press, 1991.

Metchik Robert H. and Parbudyal Singh,"Yeshiva and Faculty Unionization in Higher Education.” Labor Studies Journal 28 no. 4 (Winter 2004), 45-65.

Milden, James W. "Women, Public Libraries, and the Library Unions: The Formative Years." Journal of Library History 12 (Spring 1977): 150-58.

Monaghan, David W. "Canadian Good Roads Association." Oxford Companion to Canadian History [online edition]. Accessed October 1, 2013. http://www.oxfordreference.com.proxy.library.carleton.ca/view/10.1093/acref/97801 95415599.001.0001/acref-9780195415599-e-268.

Morton, Desmond. "Some Millennial Reflections on the State of Canadian Labour History." Labour / Le Travail 46 (Fall 2000): 11-36.

Morton, Elizabeth Homer. "The Canadian and American Library Associations." ALA Bulletin 54, no. 4 (April 1960): 283-85.

Mudge, Charlotte R. "Collective Bargaining of Librarians in Canada: Issues and Concerns." Argus 11, no. 3/4 (1982): 91-6.

Neatby, H. Blair. "The Academic Profession: An Historical Perspective. 'Communities of Scholars in Ontario'." In The Professoriate - Occupation in Crisis, 10-28.

Toronto: The Ontario Institute for Studies in Education, 1985.

Newmeyer, Jody. "The Image Problem of the Librarian: Femininity and Social Control." Journal of Library History 11, no. 1 (January 1976): 44-67.

Obituary. "Davidson Dunton Distinguished Scholar had Varied Career." The Globe and Mail. Toronto, Ontario: February 9, 1987: A.14.

Parr, Joy. "'Don't Speak For Me': Practicing Oral History Amidst the Legacies of Conflict." Journal of the CHA 2010 Revue De La SHC New Series, 21, 1: 1-11.

Pierson. Ruth. "Women's History: The State of the Art in Atlantic Canada."Acadiensis 7, no. 1 (Fall 1977): 140-62.

Portelli, Alessandro. "What Makes Oral History Different?," Reprinted in The Oral History Reader, edited by Robert Perks and Alistair Thomson, 32-42. New York: 
Routledge, 1998.

Prentice, Alison. "Boosting Husbands and Building Community: The Work of TwentiethCentury Faculty Wives." In Historical Identities. The Professoriate in Canada, edited by Paul Stortz and E. Lisa Panayotidis, 271-96. Toronto, Buffalo, London: University of Toronto Press, 2006.

Rastin, Sandra. "Organizing Tactics in a Faculty Unionization Drive in a Canadian University." Labor Studies Journal 25, no. 2 (2000): 99-119.

Reeves Joy B. and Ray Darville, "Female Clerical Workers in Academic Settings: An Empirical Test of the Gender Model," Sociological Inquiry 56, no. 1, (January 1986): 105-24.

Richardson, Hilary. "The Douglas Library in 1967" (originally published in 1998). Accessed May 3, 2012.

http://qspace.library.queensu.ca/bitstream/1974/1614/1/DOUGLAS_1967.pdf

Rowbotham, Sheila Sally Alexander and Barbara Taylor, "The Trouble with Patriarchy," reprinted in The Feminist History Reader. Edited by Sue Morgan, 51-58.

London, New York: Routledge, 2006.

Sangster, Joan. "Feminism and the Making of Canadian Working-Class

History: Exploring the Past, Present and Future,"

Labour / Le Travail 46, Special Millennium Issue (Fall 2000): 127-65.

“ "Doing Two Jobs: The Wage-Earning Mother, 1945-1970." In $A$

Diversity of Women: Ontario, 1945-1980, edited by Joy Parr. Toronto, 98-133

Buffalo, London: University of Toronto Press, 1995.

Oral History and Working Class History: A Rewarding Alliance," Oral

History/Forum d'histoire Special Issue: Working Lives: Special Issue on Oral

History and Working-Class History 33, (2013): 1-15.

"Politics and Praxis in Canadian Working-Class Oral History," in Oral History

Off the Record, edited by Anna Scheftl and Stacey Zembrzycki, 59-76. New York:

Palgrave, 2013.

"Radical Ruptures: Feminism, Labor and the Left in the Long Sixties in Canada" American Review of Canadian Studies 40, no. 1 (March 2010): 1-21.

"Telling our stories: Feminist Debates and the Use of Oral History," Women's History Review 3, no. 1 (March 1994): 5-28.

"The 1907 Bell Telephone Strike: Organizing Women Workers."

Labour / Le Travail 3 (1978): 109-30.

Savage, Donald C. "How and Why the CAUT Become Involved in Collective

Bargaining." Interchange 25, no. 1, (1994): 55-63.

Schlesinger, Benjamin. "Status of Women in Canada: Summary of Commission

Recommendations." The Family Coordinator, 20, no. 3 (July 1971): 253-58.

Szekeres, Judy. "The Invisible Workers." Journal of Higher Education Policy and

Management 26, no.1 (March 2004), 7-22.

Shanley, Catherine. “The Library Employees' Union of Greater New York, 1917-1929.”

Libraries and Culture 30, no. 3 (1995), 235-64.

Shearer, Kenneth. D. and Ray L. Carpenter. "Public Library Support and Salaries in the

Seventies." Library Journal 101, no. 6 (1976): 777-83.

Solomon, Benjamin and Robert K. Burns. "Unionization of White-Collar Employees.

Extent, Potential, and Implications," The Journal of Business 36, no. 2 (April 
1963), 141-65.

Stamp, Robert M. “Canadian High Schools in the 1920's and 1930's: The Social Challenge to the Academic Tradition." Historical Papers/Communications Historiques 13, no. 1, 1978, 76-93.

Steinberg, Ronnie J. "Gendered Instructions: Cultural Lag and Gender Bias in the Hay System of Job Evaluation.” Work and Occupations 19 (1992): 387-423.

"Emotional Labor in Job Evaluation: Redesigning Compensation Practices." Annals of the American Academy of Political and Social Science, 56 1 (1999): 143-57.

Strong-Boag, Veronica. "The Girl of the New Day: Canadian Working Women in the 1920s." Labour / Le Travail, 4 (1979): 131-64.

Taflet, Janice. "Gendered Dollars: Pin Money, Mad Money, and Changing Notions of a Woman's Proper Place.” Essays in Economic \& Business History 26, (2008): 189-202.

Taggart, W.R. "Book Selection Librarians in Canadian Universities.” Canadian Library Journal 31, no. 5 (October 1974): 410-12.

Thompson, Anthony. "The Nova Scotia Civil Service Association, 1956-1967." In Canadian Working Class History, $2^{\text {nd }}$ ed., edited by Laurel Sefton MacDowell and Ian Radforth, 641-61. Toronto: Canadian Scholar's Press Inc., 2000.

Thompson, E.P. "The Moral Economy of the English Crowd in the Eighteenth Century." Past and Present No. 50, (February 1971): 76-136.

Todd, Katherine. "Collective Bargaining and Professional Associations in the Library Field." Library Quarterly 55, no. 3: 284-99.

Tusa, Sarah D. "Serials Automation.” Acquisitions Librarian 13/14 (1995), 55-64.

Ventresca, Robert A. "'Cowering Women, Combative Men?': Femininity, Masculinity, and Ethnicity on Strike in Two Southern Ontario Towns, 1964-1966." Labour / Le Travail 39 (Spring 1997): 125-58.

Vickers, Jill. "What Makes Some Democracies More 'Women-Friendly'?” Canadian Political Science Association. Accessed September 26, 2013. http://www.cpsaacsp.ca/papers-2006/Vickers.pdf.

"In Search of Women-Friendly Democracy: Gender/Nation Relations in Modern Nation-States.” 2006 Davidson Dunton Research Lecture. Carleton University, March 27, 2006.

Weber, Mark. "Support Staff Unions in Academic and Public Libraries: Some Suggestions for Managers with Reference to the Ohio Experience, 1984-1990." Journal of Library Administration 17, no. 3 (1992): 65-86.

Weiner, Gaby. "Scholarship, Disciplinary Hegemony and Power in Academic Publishing." A paper presented at the European Conference for Educational Research, University of Ljubljana, Slovenia. September 17-20, 1998. Accessed March 29, 2012. http://www.leeds.ac.uk/educol/documents/000000795.htm.

Wilensky, Harold L. "The Professionalization of Everyone?" American Journal of Sociology 70, no. 2 (September 1964), 137-58.

Weihs, Jean. "Library Technicians in Technical Services." Library Mosaics (November/December 2004): 8-10. “The Library Technician." In Canadian Libraries in Their Changing 
Environment, edited by Lorraine Spencer Garry and Carl Garry, 420-32. Toronto:

York University, The Centre for Continuing Education, 1977.

"Women in Libraries: The Long Struggle for Equality." Interfaces 28, no. 3

(May/June 2008): 9-12.

Wier, Richard A. "Federalism, Interest Groups, and Parliamentary Government: The

Canadian Medical Association." Journal of Commonwealth Political Studies

1973, 11 no. 2 (1973): 159-75.

Zemon Davis, Natalie. "Women's History" in Transition: The European Case." Feminist

Studies 3, no. 3/4 (Spring-Summer, 1976): 83-103.

\section{Books}

Abbott, Andrew. The System of Professions. An Essay on the Division of Expert Labor.

Chicago and London: The University of Chicago Press, 1988.

Adell, B.L. and D.D. Carter. Collective Bargaining for University Faculty in Canada.

Kingston, Ontario: Industrial Relations Centre, Queen's University, 1972.

Anderson, Gregory, ed. The White-Blouse Revolution. Female Office Workers since 1870.

Manchester and New York: Manchester University Press, 1988.

Armstrong, Pat and Hugh Armstrong. The Double Ghetto. Canadian Women and Their Segregated Work. Don Mills, Ontario: Oxford University Press, 1978.

Aronowitz, Stanley. How Class Works. Power and Social Movement. New Haven and London: Yale University Press, 2003.

The Politics of Identity. Class, Culture, Social Movements. New York, London: Routledge, 1992.

Axelrod, Paul. Scholars and Dollars: Politics, Economics, and the Universities of Ontario 1945-1980. Toronto, Buffalo, London: University of Toronto Press, 1982.

Bain, George. The Growth of White-Collar Unionism. Oxford, Clarendon Press, 1970.

Blackburn, Robert H. Evolution of the Heart. A History of the University of Toronto Library up to 1981. Toronto: University of Toronto Library, 1989.

Briskin, Linda and Lynda Yatz, eds. Union Sisters. Women in the Labour Movement. Toronto: The Women's Press, 1983.

Brown, Henry Phelps. The Inequality of Pay. Oxford: Oxford University Press, 1979.

Bruneau, William. A Matter of Identities: The UBC Faculty Association, 1920-1990.

Vancouver: Faculty Association of the University of British Columbia, 1990.

Bumsted, J.M. The University of Manitoba: An Illustrated History. Winnipeg: University of Manitoba Press, 2001. E-book.

Cameron, David M. More Than an Academic Question: Universities, Government and Public Policy in Canada. Halifax: The Institute for Research on Public

Policy/L'Institut de Recherches Politiques, 1991.

Connell, R.W. Gender. Cambridge: Polity Press, 2002. Masculinities, $2^{\text {nd }}$ ed. Berkeley, Los Angeles: University of California Press, 2005.

Comacchio Cynthia R. The Infinite Bonds of Family. Domesticity in Canada, 1850 1940. Toronto, Buffalo, London: University of Toronto Press, 1999.

Crean, Susan. Grace Hartman. A Woman for Her Time. Vancouver: New Star Books, 
1995.

Creese, Gillian. Contracting Masculinity. Gender, Class and Race in a White-Collar Union, 1944-1994. Don Mills: Oxford University Press, 1999.

DeCew, Judith. Unionization in the Academy: Visions and Realities. Lanham, Maryland: Rowman and Littlefield, 2003.

Dunaway, David K. and Willa K. Baum, eds. Oral History. An Interdisciplinary Anthology, 2nd ed. Walnut Creek, London, New Delhi: Altamira Press, 1996.

Friedland, M. L. The University of Toronto: A History. Toronto: University of Toronto Press, 2002.

Frisch, Michael. A Shared Authority. Essays on the Craft and Meaning of Oral and Public History. Albany: State University of New York Press, 1990.

Frost, Stanley Brice. McGill University: For the Advancement of Learning, II, 1895 1971. Kingston and Montreal: McGill-Queen's University Press, 1984.

Garrison, Dee. Apostles of Culture: The Public Librarian and American Society, 1876-1920. New York: Free Press, 1979.

Guyton, Theodore. L. Unionization: The Viewpoint of Librarians. Chicago: American Library Association, 1975.

Hayden, Michael. Seeking a Balance. The University of Saskatchewan 1907-1982. Vancouver: University of British Columbia Press, 1983.

Heron, Craig. The Canadian Labour Movement. A Short History, $2^{\text {nd }}$. ed. Toronto: James Lorimer \& Company, 1996.

Honneth, Axel. The Struggle for Recognition. The Moral Grammar of Social Conflicts, translated by Joel Anderson. Cambridge, Massachusetts: The MIT Press, 1996.

Horn, Michiel. Academic Freedom in Canada: A History. Toronto, Buffalo, New York: University of Toronto Press, 1999.

Johns, Walter H. A History of the University of Alberta, 1908-1969. Edmonton: University of Alberta Press, 1981.

King, Carlyle. The First Fifty: Teaching, Research and Public Service at the University of Saskatchewan, 1909-1959. Toronto: McClelland and Stewart, 1959.

Moss Kanter, Rosabeth. Men and Women of the Corporation. New York: Basic Books, 1993.

Johnston, H. J. M. Radical Campus: Making Simon Fraser University. Vancouver: Douglas \& McIntyre, 2005.

Ker Conway, Jill. True North: A Memoir. Toronto: A.A. Knopf Canada, 1994.

Lesly, Philip ed. Lesly's Public Relations Handbook, $2^{\text {nd }}$ ed. Englewood Cliffs, New Jersey: Prentice-Hall, Inc., 1978.

Lowe, Graham S. Women in the Administrative Revolution: The Feminization of Clerical Work. Cambridge: Polity, 1987.

Maroney, Heather and Meg Luxton, eds. Feminism and Political Economy. Women's Work, Women's Struggles. Toronto: Methuen, 1987.

McKillop, A.B. Matters of Mind: The University in Ontario 1791-1951. Toronto, Buffalo, London: University of Toronto Press, 1994.

Moreland, Paul A. A History of Business Education. Toronto: Pitman Publishing, 1977. Morriss, Peter. Power. A Philosophical Analysis, $2^{\text {nd }}$ ed. New York: Manchester University Press, 2002.

Neatby, H. Blair and Don McEown, Creating Carleton: The Shaping of a University. 
Montreal, Kingston: McGill-Queen's University Press, 2001.

Nelson, William. H. The Search for Faculty Power. The History of the University of Toronto Faculty Association 1942-1992. Toronto: The University of Toronto Faculty Association and Canadian Scholars' Press, 1993.

Palmer, Bryan D Joan Sangster. Labouring Canada. Class, Gender and Race in Canadian Working-Class History. Don Mills: Oxford University Press, 2008.

Pearson, Ann Kristine. "Disrespectin' Administrative Work: Can We Talk?" in Whose University is it Anyway? Power and Privilege on Gendered Terrain, edited by Anne Wagner, Sandra Acker and Kimine Mayuzumi, 127-39. Toronto: Sumach Press, 2008).

Prentice, Alison, Paula Bourne, Gail Cuthbert Brandt, Beth Light, Wendy Mitchinson and Naomi Black, Canadian Women. A History. Toronto: Harcourt Brace Jovanovich, 1988.

Porter, John. The Vertical Mosaic. An Analysis of Social Class and Power in Canada, Toronto: University of Toronto Press, 1965.

Queen's University. Queen's Encyclopedia (online). http://www.queensu.ca/encyclopedia/w/womenatqueens.html.

Raleigh Yow, Valerie. Recording Oral History. A Guide for the Humanities and Social Sciences, 2nd ed. London, New York: Rowman \& Littlefield Publishers Inc., 2005.

Rebick Judy. Ten Thousand Roses: The Making of a Feminist Revolution. Toronto: Penguin Canada, 2005.

Reid, John G. Mount Allison University: A History to 1963. Toronto: University of Toronto Press, 1984.

Ross, Robin. The Short Road Down. A University Changes. Toronto: University of Toronto Press, 1984.

Rouillard, Jacques. Apprivoiser le Syndicalisme en Milieu Universitaire. Histoire du Syndicat Général des Professeurs et Professeures de l'Université de Montréal. Montreal: Boréal, 2006.

Sangster, Joan. Transforming Labour. Women and Work in Postwar Canada. Toronto, Buffalo, London: University of Toronto Press, 2010.

Spinks, J. W. T. Decade of Change: The University of Saskatchewan, 1959-70. Saskatoon: University of Saskatchewan, 1972.

Strauss, Anselm L. and Juliet Corbin, eds. Basics of Qualitative Research: Techniques and procedures for Developing Grounded Theory, $2^{\text {nd }}$ ed. Thousand Oaks: Sage Publications, 1998.

Sufrin, Eileen. The Eaton Drive. The Campaign to Organize Canada's Largest Department Store. 1948 to 1952. Toronto, Montreal, Winnipeg, Vancouver: Fitzhenry \& Whiteside, 1982.

Swettenham, John and David Kealy. Serving the State: A History of the Professional Institute of The Public Service of Canada 1920-1970. Ottawa: Le Droit, 1970.

Taylor, John. Ottawa. An Illustrated History. Toronto: James Lorimer \& Company and Canadian Museum of Civilization, 1986.

The Bank Book Collective, illustrations and cover by Pat Davitt. An Account to Settle. The Story of the United Bank Workers (SORWUC). Vancouver: Press Gang Publishers, 1979). 
The Chilly Collective, eds. Breaking Anonymity. The Chilly Climate for Women Faculty. Waterloo, Ontario: Wilfrid Laurier University Press, 1995.

Thompson, E.P. The Making of the English Working Class. Hammondsworth, England: Penguin, 1963.

Thompson, Paul. The Voice of the Past. Oral History, $3^{\text {rd }}$ ed. Oxford, New York: Oxford University Press, 2009.

Van de Graaff, John H., Burton R. Clark, Dorotea Furth, Dietrich Goldschmidt, and Wheeler, Donald F. Academic Power. Patterns of Authority in Seven National Systems of Higher Education. New York: Praeger Publishers, 1978.

Weber, Max. From Max Weber: Essays in Sociology, translated and edited by H. H. Gerth and C. Wright Mills. New York: Oxford University Press, 1958.

Weibel, Kathleen and Kathleen M. Heim with assistance from Dianne J. Ellsworth. The Role of Women in Librarianship 1876-1976: The Entry, Advancement, and Struggle for Equalization in One Profession. Phoenix: Oryx Press, 1979.

White, Julie. Mail \& Female. Women and the Canadian Union of Postal Workers. Toronto: Thompson Educational Publishing, Inc., 1990.

White, Julie. Sisters and Solidarity. Women and Unions in Canada. Toronto: Thompson Educational Publishing, 1993.

Williamson, Charles C. The Williamson Reports of 1921 and 1923. Metuchen, New Jersey: Scarecrow Press Inc., 1921.

\section{Conference proceedings}

Bissell, Claude. "The Problems and Opportunities of Canada's Universities," Canada's Universities in a New Age, Proceedings of a Conference Held by the National

Conference of Canadian Universities and Colleges. Ottawa: Le Droit, 1962.

Canadian Library Association. Canadian Library Association Conference 1973 Proceedings. (Ottawa: Canadian Library Association, 1973).

Mac Con Iomaire, Mairtin. "Hidden Voices from the Culinary Past: Oral History as a Tool for Culinary Historians.” Accessed November 26, 2013. http://arrow.dit.ie/tfschcafcon/5/.

\section{Media advisories}

Canadian Union of Public Employees. Media Advisory: CUPE Kingston Office to Honour Long-Time Kingston Labour Activists-Building Dedication Ceremony on Monday October 4 [2010]. Accessed on November 10, 2013. http://www.marketwired.com/press-release/media-advisory-cupe-kingston-officehonour-long-time-kingston-labour-activists-building-1328349.htm.

\section{Theses}

Bennett, Joy "From Gentlemen's Agreements to Collective Agreements: How the Unionization of Full Time Faculty Members in Anglophone Canadian Universities has Changed the Management and Governance Structures of those Universities.” Doctoral thesis, Concordia University, 1992. 
Jensen, Stefan. "Dodging the Steamroller: The Unionization of Professors at Saint Mary's University, 1963-79." Doctoral thesis, Memorial University of Newfoundland, 2008.

Mair, Debra. "Unionization and the Middle Class: The Case of University Faculty." Master's thesis, Carleton University, 1977.

Milner, Nina. "Lady Librarian": The Feminization of Librarianship in Canada, 1880-1920." Master's thesis, University of Ottawa, 1992.

Mudge, Charlotte R. "Bargaining Unit Composition and Negotiation Outcomes: A Study of Academic and Public Library Personnel in Ontario.” Doctoral thesis, University of Toronto, 1984.

Warsket, Rosemary, "Learning to be 'Uncivil': Class Formation and Feminisation in the Public Service Alliance of Canada, 1966-1996." Doctoral thesis, Carleton University, 1998.

\section{Websites}

Carleton University. 1999-2000 Undergraduate Calendar. Bursaries. Jean A. Loates, Bursary. Accessed October 20, 2013.

http://www3.carleton.ca/cu9900uc/awards/Bursaries.html, accessed October 20, 2013.

Legacy.com. Donald Rowat, obituary.

http://www.legacy.com/obituaries/remembering/obituary.aspx?page=lifestory\&pid= 120929380, accessed November 26, 2013.

United Nations. "WomenWatch. Information and Resources on Gender Equality and Empowerment of Women. History of International Women's Day," 2013. Accessed May 1, 2013. http://www.un.org/womenwatch/feature/iwd/history.html.

Willis Business College. Accessed November 25, 2013. www.williscollege.com. 